\title{
STUDI PETROLOGI DAN POLA KIMIA \\ KOMPLEK OFIOLIT KARANGSAMBUNG UTARA \\ LUH ULO, JAWA TENGAH
}
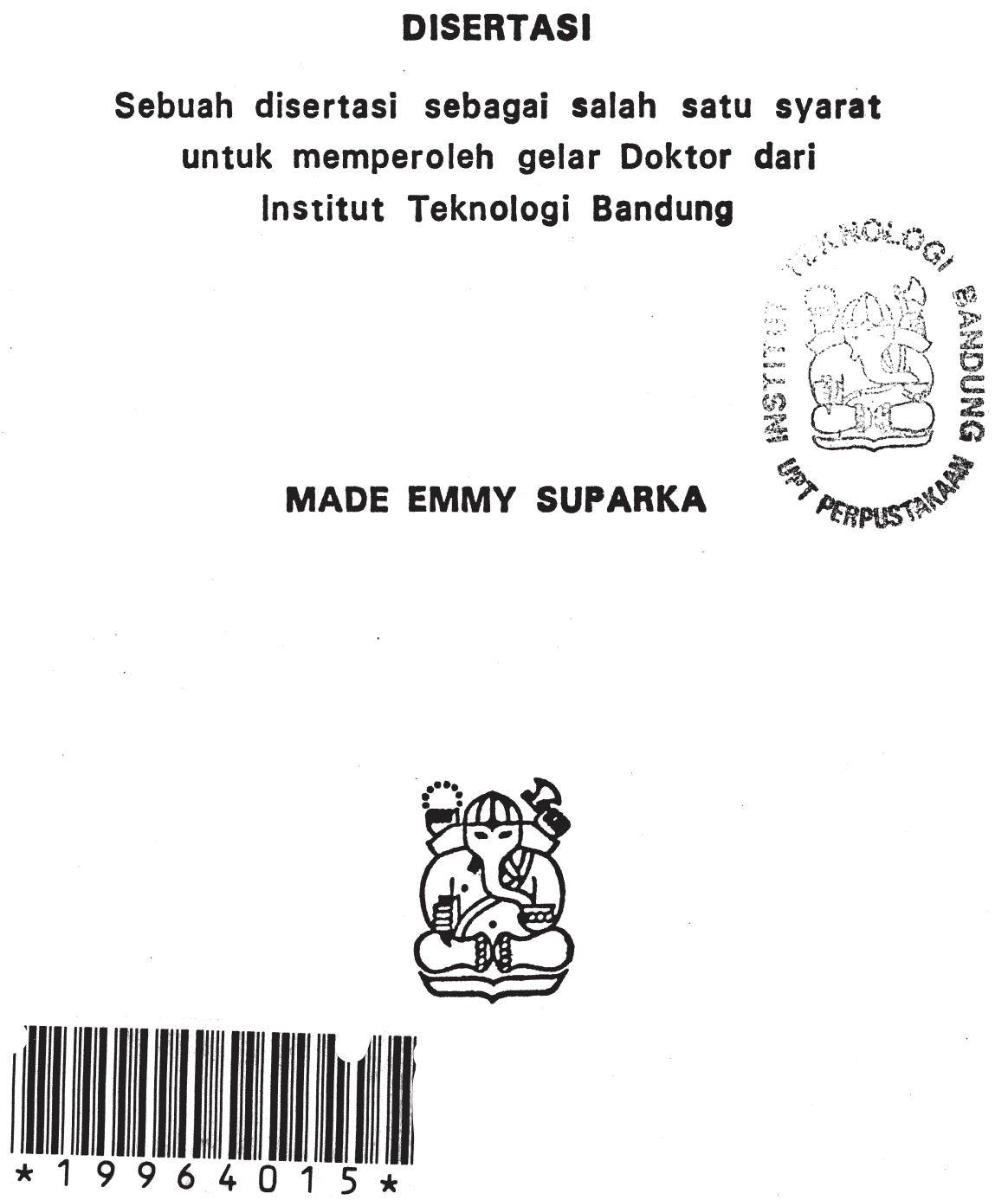

INS TITU' rEKNOLOU. BANDUNG 
STUDI PETROLOGI DAN POLA KIMIA

KOMPLEK OFIOLIT KARANGSAMBUNG UTARA

LUH ULO, JAWA TENGAH

oleh

MADE EMMY SUPARKA

INSTITUT TEKNOLOGI BANDUNG

1988 
ABSTRAK DISERTASI

MADE EMMY SUPARKA

INSTITUT TEKNOLOGI BANDUNG 1988 。 


\title{
STUDI PETROLOGI DAN POLA KIMIA \\ KOMPLEK OFIOLIT KARANGSAMBUNG UTARA \\ LUH ULO, JAWA TENGAH
}

\begin{abstract}
ABSTRAK DISERTASI
Sebuah disertasi sebagai salah satu syarat untuk memperoleh gelar Doktor dari

Institut Teknologi Bandung
\end{abstract}

Oleh

Made Emmy Suparka

Promotor : Prof. Dr. R. Soeria-Atmadja

Institut Teknologi Bandung

1988 


\section{ABSTRAK DISERTASI}

Penelitian berupa studi tentang genesis himpunan batuan mafis ultramafis daerah Karangsambung Utara, Luh Ulo - Jawa Tengah khususnya ditinjau dari ciri-ciri petrologi dan pola kimianya. Masalah penempatan (emplacement) himpunan batuan tersebut pada keadaan sekarang juga merupakan sesuatu hal yang cukup penting untuk diteliti guna melengkapi dan merevisi model penempatan yang telah ada. Sebagai studi perbandingan dipilih ofiolit Peg. Meratus - Bobaris di Kalimantan Tenggara.

Himpunan batuan mafis - ultramafis daerah penelitian menempati daerah seluas lebih kurang $10 \times 3,5 \mathrm{~km}^{2}$, dengan pola penyebaran berarah timurlaut baratdaya, termasuk ke dalam salah satu batuan berumur Pratersier. Hasil analisis kimia unsur-unsur utama, jejak, dan unsur tanah langka menunjukkan bahwa himpunan batuan mafis - ultramafis daerah penelitian memperlihatkan hubungan ko genetis. Hal ini berarti himpunan batuan mafis - ultramafis daerah Karangsambung Utara merupakan satu komplek ofiolit dan dapat digolongkan ke dalam ofiolit kelas II berdasarkan klasifikasi Miyashiro. Ofiolit tersebut dicirikan oleh kehadiran batuan volkanis berafinitas toleit yang pada umumnya terbentuk di lingkungan samudera

Hasil analisis mikroprob mineral piroksen dari basalt dan gabro, serta data

isotop $\left({ }^{87} \mathrm{Sr} /{ }^{86} \mathrm{Sr}=0,703218-0,704311\right.$, dan $\left.{ }^{143} \mathrm{Nd} /{ }^{144} \mathrm{Nd}=0,513073-0,513171\right)$ menunjukkan ciri ofiolit yang terbentuk di punggung tengah samudera (midoceanic ridge).

Analisis unsur tanah langka (UTL) yaitu kelompok unsur lantanida (La, $\mathrm{Ce}, \mathrm{Nd}, \mathrm{Sm}, \mathrm{Eu}, \mathrm{Gd}, \mathrm{Dy}, \mathrm{Er}, \mathrm{Yb}, \mathrm{Lu})$ dengan metode spektrometri masa dengan pengenceran isotop (mass spectrometric isotope dilution) memberikan hasil berupa pola normalisasi kondrit yang mendatar dengan kelipatan 10 kali untuk batuan volkanisnya. Hal ini menunjukkan karakteristik dari batuan volkanis yang terbentuk pada punggung tengah samudera, tergolong ke dalam tipe-N 
menurut klasifikasi Sun et al.

Di lapangan komplek ofiolit daerah Karangsambung Utara terdiri dari basalt berstruktur bantal, retas-retas diabas, gabro (kumulat dan non kumulat), peridotit terserpentinkan, lersolit, serta serpentinit. Himpunan batuan ini memperlihatkan deformasi yang kuat; dicirikan oleh gejala milonitisasi, breksiasi dan juga adanya barik-barik ataupun urat-urat yang telah terisi oleh mineral sekunder seperti kuarsa, karbonat, epidot, dan klorit. Bahkan batas antar satuan batuan di dalam komplek ofiolit ini adalah sesar (umumnya sesar sungkup). Gejala ubahan seperti proses hidrotermal maupun pemalihan (fasies seolit dan sekis hijau) merupakan gejala umum teramati pada semua conto batuan. Di dalam komplek ofiolit kadang-kadang ditemukan bongkah-bongkah batuan lainnya mencakup batuan sedimen (rijang, batugamping merah, greywake), dan batuan malihan (sekis mika, sekis amfibolit, sekis glaukofan, serta meta kuarsit).

Berdasarkan kepada macam batuan yang dijumpai (khususnya himpunan batuan mafis - ultramafisnya) serta struktur di lapangan maka ofiolit daerah penelitian dapat digolongkan ke dalam jenis ofiolit terpisah-pisah dan termalihkan (dismembered \& metamorphosed ophiolite).

Ofiolit di Kalimantan Tenggara menempati dua pegunungan yaitu Meratus dan Bobaris yang berarah lebih kurang timurlaut - baratdaya. Himpunan batuan tersebut terdiri dari basalt berstruktur bantal, gabro, dunit, peridotit piroksen, piroksenit, dan plagiogranit. Dengan demikian dapat digolongkan ke dalam ofiolit tak lengkap (incomplete ophiolite). Pola kimianya menunjukkan ofiolit yang terbentuk di busur kepulauan, dicirikan oleh kehadiran batuan volkanis yang berafinitas dominan toleit dan batuan volkanis kalk alkali dalam jumlah relatif sedikit. Hal ini didukung oleh data isotop yang memperlihatkan angka perbandingan ${ }^{87} \mathrm{Sr}{ }^{86} \mathrm{Sr}=0,7038-0,7041 \mathrm{dan}$ ${ }^{143} \mathrm{Nd} /{ }^{144} \mathrm{Nd}=0,51285-0,51350$. Pentarikhan umur dengan K-Ar terhadap plagiogranit dan meta diabas yang mewakili ofiolit daerah ini menunjukkan 
umur Kapur Tengah atau Cenomanian (116-95 jt.).

Mekanisme penempatan ofiolit Karangsambung Utara pada kedudukan sekarang adalah sebagai akibat pertemuan lempeng benua Eurasia dan lempeng Samudera Hindia di selatan P. Jawa pada jaman Kapur yang menyebabkan terjadinya penunjaman lempeng Samudera Hindia ke bawah lempeng benua Eurasia. Pada akhir penunjaman tersebut kepingan dari punggung tengah samudera jaman Kapur Akhir (85-81 jt) ikut terbawa dan tercuatkan ke atas tepian lempeng benua. Sedangkan di wilayah Indonesia Timur pada kala yang lebih kurang bersamaan, terjadi benturan antara lempeng benua Eurasia bagian timur dengan lempeng samudera Pasifik yang mengakibatkan tercuatnya kepingan dari busur kepulauan tak dewasa yang berumur Cenomanian ke atas lempeng benua Eurasia bagian timur, menghasilkan ofiolit yang sekarang ditemukan di Peg. Meratus dan Bobaris. 


\section{DISSERTATION ABSTRACT \\ STUDY ON PETROLOGY AND GEOCHEMISTRY OF NORTH \\ KARANGSAMBUNG OPHIOLITE, LUH ULO, CENTRAL JAVA}

Exposures of mafic and ultramafic rocks have been found north of Karangsambung area along approximately NE-SW trending zone measuring $10 \times 3.5$ square kilometers. Recent studies on their geochemistry (including major-, trace- \& rare earth-elements) reveal that they represent class II ophiolite of Miyashiro's classification which indicate emplacement within oceanic environment. Results of microprobe analyses on several pyroxenes from basalt and gabbro as well as isotopic data $\left({ }^{87} \mathrm{Sr} /{ }^{86} \mathrm{Sr}=0.703218-0.704311\right.$ and ${ }^{143} \mathrm{Nd}$ $\left.f^{144} \mathrm{Nd}=0.513073-0.51371\right)$ show typical mid-oceanic ridge ophiolite. REE abundances in most of the studied volcanics are about ten times chondrites with relative LREE depletion; and these point to N-type MORB. Field evidence indicates that the ophiolite rock assemblage are dismembered and have been affected by greenschist- and zeolite-facies metamorphism and deformation. It consists of pillow basalts, diabase sheeted dykes, cumulus- \& non-cumulus gabbros, serpentinized peridotites, lherzolites, and serpentinites. A few blocks of sedimentary- and metamorphic-rocks are rarely observed within this complex.

The ophiolite complex from Meratus-Bobaris mountains in SE Kalimantan has been selected for comparison. It is made up of an incomplete ophiolite rock assemblage consisting of pillow basalts, metadiabases, gabbros, dunites, pyroxene-peridotites, pyroxenites and plagiogranites. Result of geochemical studies of these rocks favor an island arc environment; such tectonic environment is also indicated by the following ratios ${ }^{87} \mathrm{Sr} /{ }^{86} \mathrm{Sr}=$ $0.7038-0.7041$ and ${ }^{143} \mathrm{Nd} /{ }^{144} \mathrm{Nd}=0.51285-0.51350$. The volcanic rocks are represented by tholeiitic- and minor calc alkaline rock-series. $\mathrm{K}-\mathrm{Ar}$ ages of metadiabase and plagiogranite give 116-95 my. (Cenomanian). 
The emplacement of Karangsambung ophiolites has been interpreted as the result of subduction of the Indian Ocean Plate beneath the Eurasian Plate during Cretaceous time. They represent segments of a Late Cretaceous (85-81 my) mid-oceanic ridge which have obducted onto the consuming plate margin following the subduction period. At about the same time, in East Indonesia, a collision between Pacific Plate and eastern part of Eurasian Plate took place, resulting into the emplacement of Meratus-Bobaris ophiolites. The latter have been interpreted as segments of an ancient Cenomanian island arc which have obducted onto continental plate margin. 
STUDI PETROLOGI DAN POLA KIMIA

KOMPLEKS OFIOLIT KARANG SAMBUNG UTARA

LUH ULO, JAWA TENGAH

Made Emmy Suparka

INSTITUT TEKNOLOGI BANDUNG

1988 


\section{STUDI PETROLOGI DAN POLA KIMIA KOMPLEKS OFIOLIT KARANGSAMBUNG UTARA \\ LUH ULO, JAWA TENGAH}

DISERTASI

Sebuah disertasi sebagai salah satu syarat untuk memperoleh gelar Doktor dari

Institut Teknologi Bandung

oleh

Made Emmy Suparka

Institut Teknologi Bandung

1988 


\section{STUDI PETROLOGI DAN POLA KIMIA}

KOMPLEK OFIOLIT KARANGSAMBUNG UTARA

LUH ULO, JAWA TENGAH

Oleh

Made Emmy Suparka

Menyetujui

a/n. Team Promotor

Ketua

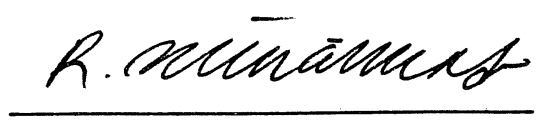

(Prof. Dr. R. Soeria Atmadja) 


\section{PEDOMAN PENGGUNAAN DISERTASI}

Disertasi Doktor yang tidak dipublikasikan terdaftar dan tersedia di Perpustakaan Institut Teknologi Bandung, adalah terbuka untuk umum dengan ketentuan bahwa hak cipta ada pada pengarang. Referensi kepustakaan diperkenankan dicatat, tetapi pengutipan atau ringkasan hanya dapat dilakukan seizin pengarang dan harus disertai dengan kebiasaan ilmiah untuk menyebutkan sumbernya.

Memperbanyak atau menerbitkan sebagian atau seluruh disertasi haruslah seizin Dekan Fakultas Pasca Sarjana, Institut Teknologi Bandung.

Perpustakaan yang meminjam disertasi ini untuk kepentingan anggotanya diharapkan mengisi nama dan tanda tangan peminjam dan tanggal pinjam. 
Dipersembahkan kepada

Ibunda, suami dan anakku tercinta 


\section{UCAPAN TERIMA KASIH}

Pertama-tama penulis berterima kasih kepada promotornya, Prof. DR. Rubini Soeria-Atmadja yang telah mendorong untuk melakukan penelitian yang sangat menarik ini, dan atas segala saran, bimbingan serta nasehatnya selama penelitian berlangsung dan selama penulisan disertasi ini.

Penulis juga sangat menghargai dan berterima kasih kepada para anggota Panitia Penilai yang terdiri dari Prof. DR. S. Sartono, Prof. DR. Sukendar Asikin, DR. Ong Han Ling, dan DR.Ir. Fred Hehuwat atas segala saran, kritik, serta petunjuk yang berharga sehingga disertasi ini mempunyai bentuk seperti yang sekarang.

Kepada Institut Teknologi Bandung, khususnya kepada Pimpinan Pasca Sarjana, Institut Teknologi Bandung, penulis mengucapkan terima kasihnya atas segala fasilitas yang diberikan selama proses pengerjaan hingga penyelesaian disertasi ini. Rekan-rekan staf pengajar di Jurusan Teknik Geologi, khususnya DR.Ir. A.T. Rahardjo, DR.Ir. N.A. Magetsari, dan Ir. M. Iwan Tachyudin MSc. telah banyak memberi bantuan berupa pemikiran, diskusi-diskusi serta dorongan moril. Untuk itu penulis sangat berterima kasih.

Ucapan terima kasih juga disampaikan kepada M. C.J. Allegre selaku Gurubesar serta Kepala Laboratoire de geochimie et cosmochimie, Universite de Paris VI yang telah berkenan membimbing serta memberi pengarahan yang sangat berarti selama penulis melakukan program sandwich, dan atas kepercayaan beliau dengan mengangkat penulis sebagai salah satu assistence de recherche selama satu tahun (1982-1983). Begitu juga kepada Mme. Mireille POLVE, M. Michel LOUBET, M. Alain PRINZHOFER, serta rekan-rekan di laboratorium yang sama, penulis sangat berterima kasih.

Kepada M. Henri BOUGAULT beserta asistennya di laboratoire de petrologie de CNEXO-COB di Brest, penulis sangat berhutang budi atas segala bantuannya selama melakukan analisis di laboratorium tersebut. Ucapan yang 
sama penulis berikan kepada M. R.C. Maury, DR. Ir. Y. Suyatno Yuwono, atas bantuannya dalam analisis mikroprob serta beberapa saran yang diberikan. Juga kepada M. H. Bellon yang telah membantu dalam pentarikhan radiometri.

Penulis merasa sangat berhutang budi kepada segenap asisten, serta karyawan khususnya di Laboratorium Petrologi dan Geologi Ekonomi yang telah banyak membantu penulis, terutama dalam hal penyelesaian disertasi ini.

Ucapan terima kasih disampaikan kepada bapak B.N. Wahyu dan keluarga dari P.T. Inco beserta staf yang telah memberi kesempatan kepada penulis untuk melakukan tinjauan geologi daerah tersebut dalam rangka studi perbandingan. Begitu juga kepada Mme. \& M. Phillipe BASSOULET di Brest yang telah mengijinkan penulis untuk tinggal dirumahnya selama penulis melakukan pekerjaan laboratorium di Brest.

Di lapangan penulis diterima secara ramah dan baik hati oleh keluarga Soedjoko, dan almarhum bapak Glondong Karangsambung, Mantan Kepala Desa Seboro, dan bapak Kepala Desa Lokidang. Berkat bantuan mereka, pekerjaan lapangan dapat berjalan lancar.

Akhirnya penulis ingin mengucapkan rasa terima kasih yang tak terhingga kepada suami serta anaknya atas segala pengorbanan dan pengertian mereka selama masa penelitian baik di dalam negeri, terlebih selama penulis di luar negeri, hingga selesainya pembuatan disertasi, dimana penulis sebagai ibu rumahtangga kurang memperhatikan mereka. Begitu juga atas dorongan serta bantuan suaminya berupa diskusi serta saran yang sangat membantu penyelesaian disertasi ini. 
Halaman

Daftar isi $\ldots \ldots \ldots \ldots \ldots \ldots \ldots \ldots \ldots \ldots \ldots \ldots \ldots \ldots \ldots \ldots$

Daftar Gambar ................................ xviii

Daftar Foto .......................... xxiii

Daftar Lampiran ...................... xxvi

Bab I. PENDAHULUAN ................... 1

1.1. Latar Belakang Permasalahan ................ 3

1.2. Ofiolit dan Permasalahannya ................. 5

1.3. Masalah Ofiolit di Luh Ulo - Jawa Tengah .......... 7

1.4. Tujuan Penelitian ...................... 9

1.5. Metode Penelitian ........................ 10

1.5.1. Metode lapangan ................... 10

1.5.2. Metode laboratorium ............... 11

1.5.2.1. Analisis Petrografi ............. 11

1.5.2.2. Metode mass spectrometric isotope dilution $\ldots \ldots \ldots \ldots \ldots \ldots \ldots \ldots \ldots$

1.5.2.3. Metode Pendar Sinar X (X-Ray 13 fluorescence)

1.5.2.4. Metode Analisis Mikroprob ......... 13

1.5.2.5. Metode Pentarikhan Radiometri K-Ar 16

1.5.3. Studi Perbandingan ................. 17

Bab II. TATANAN TEKTONIK REGIONAL ............. 18

2.1. Kerangka Tektonik Pulau Jawa ................ 18

2.2. Geologi Daerah Luh Ulo ................. 23

2.2.1. Stratigrafi Daerah Luh Ulo .............. 23 
xvi

Halaman

2.2.1.1. Stratigrafi Batuan Pratersier ........ 23

2.2.1.2. Stratigrafi Batuan Tersier.......... 30

2.2.2. Ofiolit Karangsambung Utara ............ 32

2.2.2.1. Ciri-ciri Umum di Lapangan ........ 32

2.2.2.1.1. Batuan Ultramafis ........ 34

2.2.2.1.2. Batuan Mafis ............ 34

2.2.2.2. Geokronologi ................ 49

Bab III. PETROGRAFI DAN MINERALOGI ........... 51

3.1. Petrografi $\ldots \ldots \ldots \ldots \ldots \ldots \ldots \ldots \ldots \ldots \ldots \ldots \ldots \ldots \ldots \ldots$

3.1.1. Serpentinit (harsburgit terserpentinkan)...... 51

3.1.2. Lersolit ...................... 52

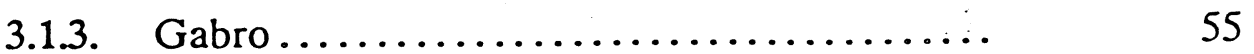

3.1.4. Diabas dan Basalt ................. 62

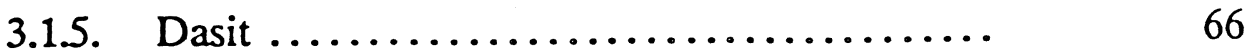

3.2. Mineralogi $\ldots \ldots \ldots \ldots \ldots \ldots \ldots \ldots \ldots \ldots \ldots \ldots \ldots \ldots$

3.2.1. Komposisi Klinopiroksen .............. 68

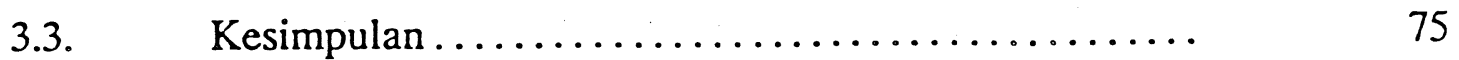

Bab IV. PETROLOGI DAN GEOKIMIA .............. 79

4.1: Unsur Utama dan Unsur Jejak .............. 79

4.1.1. Beberapa Diagram Evolusi Magma ......... 80

4.1.2. Beberapa Diagram Diskriminasi Geokimia .... 85

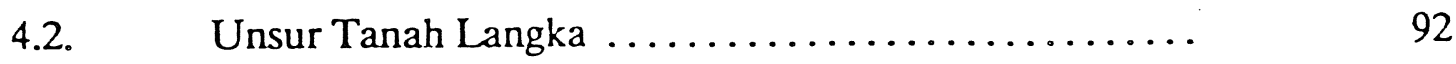

4.2.1. Normalisasi Kondrit ................ 93

4.2.1.1. Kondrit ................. 95

4.2.1.2. Diagram-diagram Normalisasi Kondrit 97 
xvii

Halaman

4.2.1.3. Beberapa Diagram Log-log UTL....

4.3. Kesimpulan ........................ 105

Bab V. OFIOLIT PEGUNUNGAN MERATUS-BOBARIS ... 112

5.1. Tinjauan Geologi ..................... 112

5.2. Petrologi dan Geokimia ................... 114

5.2.1. Beberapa Diagram Evolusi Magma dan Diskriminasi Geokimia ................. 114

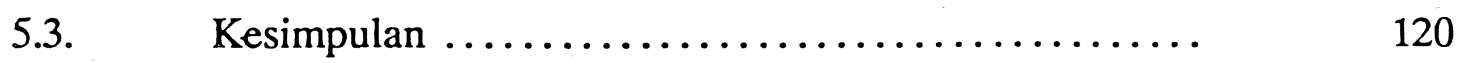

Bab VI. DISKUSI DAN SINTESIS ................ 125

6.1. Genesis dan Penempatan Komplek Ofiolit Karangsambung Utara $\ldots \ldots \ldots \ldots \ldots \ldots \ldots \ldots \ldots \ldots \ldots \ldots \ldots \ldots \ldots \ldots \ldots \ldots$

6.2. Genesis dan Penempatan Ofiolit Pegunungan Meratus -

Bobaris .......................... 129

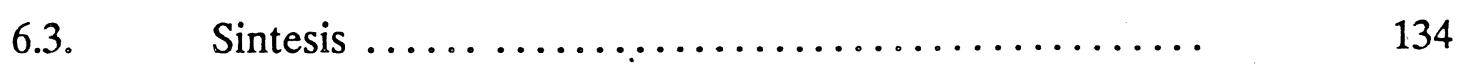

DAFTAR PUSTAKA .................. 139 


\section{DAFT A R G A B A R}

Gambar

Halaman

I.1. Peta distribusi ofiolit di Indonesia (dimodifikasi dari Hutchison 1975, Burgath dkk. 1983) ..............

I.2. Peta distribusi ofiolit di dunia (dikutip dari Coleman, 1977) ................................... 4

I.3. Peta indeks daerah penelitian $\ldots \ldots \ldots \ldots \ldots \ldots \ldots . . .6$

I.4. Pengenceran isotopik ................... 14

I.5. Prosedur preparasi conto dengan metode pengenceran

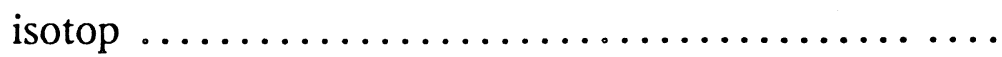

II.1. Perkembangan busur kepulauan di Indonesia bagian barat pada jaman Kapur Atas - Eosen (Sukendar, 1974) ...

II.2. Data jenis dan umur conto batuan dasar yang diperoleh dari sumur-sumur minyak di baratlaut Jawa, Laut Jawa, dan Cekungan Barito (dikutip dari Hamilton, 1979)

II.3. Pergerakan-pergerakan lempeng Hindia - Australia pada jaman Tersier (dikutip dari Davies, 1984).......... 22

II.4. Stratigrafi daerah Luh Ulo, Jawa Tengah ..........

II.5. Model sedimentasi daerah Luh Ulo, dimodifikasi dari Moore \& Karig (1976) . ..................

II.6. Stratigrafi daerah Luh Ulo menurut Sukendar (1974) dan modifikasi penulis $(1988) \ldots \ldots \ldots \ldots \ldots \ldots \ldots . \ldots \ldots$

II.7. Peta geologi daerah Luh Ulo (Sukendar, 1974) ...... 33

II.8. Lintasan pengamatan melalui S. Pakuruhan ......... 43

II.9. Lintasan pengamatan melalui S. Curugdawa ......... 44

II.10. Lintasan pengamatan melalui S. Medana ............ 45

II.11. Lintasan pengamatan melalui S. Lokidang .......... 46 
II.12. Lintasan pengamatan melalui S.Parakansubah .........

II.13a. Penampang kolom ofiolit lintasan di sungai-sungai Pakuruhan, Curugdawa, Medana, Lokidang \& Parakansubah

II.13b. Penampang kolom ofiolit Karangsambung Utara dibandingkan dengan penampang kolom ofiolit yang ideal dan ofiolit Meratus, Kalimantan Tenggara ..............

III.1. Perajahan mineral-mineral plagioklas dari basalt (ST-69) dan gabro (CD-7, PS-16) Karangsambung Utara di dalam diagram $\mathrm{An}-\mathrm{Ab}$ - Or

III.2. Komposisi klinopiroksen dari basalt dan gabro, dalam diagram Wo-En-Fs

III.3. Diagram korelasi antara kation $\mathrm{Fe}^{3+}, \mathrm{Ti}^{4+}, \mathrm{Mn}^{2+}$ dengan FM dari mineral klinopiroksen basalt, diabas, gabro .................................

III.4. Diagram korelasi antara kation $\mathrm{Na}^{+}, \mathrm{Ti}^{4+}, \mathrm{Al}$ IV dan Al VI dengan FM dari mineral klinopiroksen : basalt,

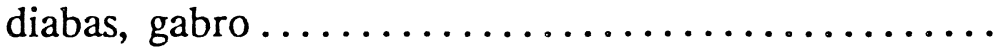

III.5. Diagram korelasi antara komponen-komponen non kuadrilateral dari klinopiroksen : basalt, diabas, gabro . .

III.6. Diagram korelasi antara komponen-komponen non kuadrilateral dari klinopiroksen : basalt, diabas, gabro ..

III.7a\&b. Perajahan komposisi klinopiroksen di dalam diagram Leterrier et al. (1982); basalt, gabro ...............

III.8. Distribusi mineral klinopiroksen di dalam diagram diskriminasi dari Leterrier et al. (1982); basalt, gabro .....

IV.1a. Diagram variasi Oksida sebagai fungsi dari ID (indek 
diferensiasi); gabro, diabas dan basalt ..............

IV.1b. Diagram variasi Oksida sebagai fungsi dari ID (indek diferensiasi); gabro, diabas dan basalt ...............

IV.2. Perajahan himpunan batuan ofiolit Karangsambung Utara di dalam diagram AMF ; basalt, diabas dan gabro ....

IV.3. Distribusi himpunan basalt, diabas, gabro di dalam diagram $\mathrm{FeO}^{*}, \mathrm{TiO}_{2}, \mathrm{SiO}_{2}$ versus $\mathrm{FeO}^{*} / \mathrm{MgO} \ldots . . . \ldots .$.

IV.4. Perajahan himpunan batuan basalt, diabas, gabro di dalam diagram $\mathrm{Ni}, \mathrm{Cr}$ versus $\mathrm{FeO}^{*} / \mathrm{MgO} \ldots \ldots \ldots \ldots$.

IV.5. Distribusi himpunan batuan basalt, diabas, gabro daerah Karangsambung Utara di dalam diagram Miyashiro \& Shido (1975) ................................

IV.6. Distribusi basalt, diabas, gabro, daerah penyelidikan di dalam diagram Miyashiro \& Shido (1975) ..........

IV.7. Distribusi batuan basalt, diabas, gabro daerah Karangsambung Utara di dalam diagram $\mathrm{TiO}_{2}-\mathrm{Fe}^{*} \mathrm{O} / \mathrm{MgO}$. .

IV.8. Distribusi himpunan batuan basalt, diabas, gabro daerah Karangsambung Utara di dalam diagram V-Ti / 1000 (Shervais, 1982) .......................

IV.9. Perajahan kelimpahan UTL dibandingkan dengan nomor atom; a; UTL basalt daerah penyelidikan, b; UTL dari sistem solar (Cameron, 1973), c; UTL basalt hipotesis dari Haskin, 1984 ...................

IV.10. Metode normalisasi kelimpahan UTL dengan kondrit : . = kondrit, : basalt daerah penyelidikan, : hasil

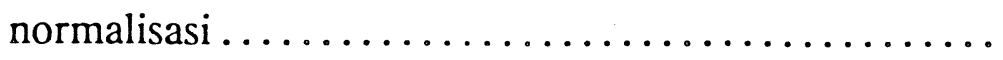


IV.11. Pola fraksinasi UTL basalt toleit ( $\mathrm{t}$ ) dan macam-macam basalt alkali dari berbagai tempat di dunia; khusus pada gambar IV.11d. terlihat pola fraksinasi dari basalt-toleit punggung tengah samudera (Schilling, 1971), b.m.n = basalt melilit-nefelin, b.o.a = basalt olivin-alkali, b.a.t $=$ basalt alumina tinggi, b.a. = basalt alkali, $\mathrm{t}=$ toleit $\ldots$.

IV.12. Pola fraksinasi UTL batuan basalt (a) dan diabas (b) daerah penyelidikan ....................... 99

IV.12c. Pola fraksinasi UTL batuan gabro daerah penyelidikan .

IV.13. Diagram yang memperlihatkan pembentukan ofiolit

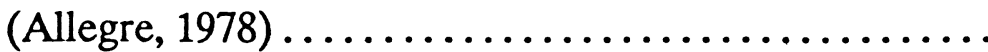

IV.14. Perajahan batuan basalt, diabas, dan gabro di dalam diagram log-log Ce-Nd (a), Er - Yb (b), dan Sm - Nd (c)

IV.15. Pola fraksinasi UTL basalt daerah penyelidikan dibandingkan dengan pola fraksinasi UTL umum dari basalt PTS (punggung tengah samudera) ..........

IV.16. Pola fraksinasi UTL basalt daerah penyelidikan dibandingkan dengan fraksinasi basalt toleit tipe $\mathrm{N}$, dari beberapa punggung tengah samudera (dikutip dari

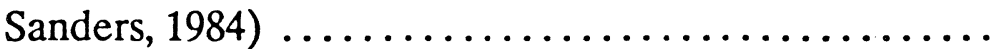

IV.17. Pola fraksinasi UTL dari basalt toleit punggung tengah samudera dan benua dari beberapa tempat di dunia (dimodifikasi dari Schilling, 1971)

IV.18. Pola fraksinasi UTL rijang Karangsambung Utara ......

V.1. Distribusi dari unit batuan di dalam komplek ofiolit Meratus - Bobaris (dimodifikasi dari Sikumbang, 1986) .

V.2. Perajahan ofiolit Meratus - Bobaris di dalam diagram 
xxii

Halaman

$\log -\log$ Ce \& V versus La; basalt, diabas dan gabro .....

V.3. Distribusi batuan basalt, diabas, gabro, piroksenit dan dunit dari ofiolit Meratus - Bobaris di dalam diagram $\mathrm{FeO}^{*}-\mathrm{FeO}^{*} / \mathrm{MgO}$ (Miyashiro \& Shido, 1975) .........

V.4. Distribusi batuan basalt, diabas, gabro, piroksenit dan dunit dari ofiolit Meratus - Bobaris di dalam diagram $\mathrm{TiO}_{2}-\mathrm{FeO}^{*} / \mathrm{MgO} \ldots \ldots \ldots \ldots \ldots \ldots \ldots \ldots \ldots . . . \ldots \ldots$

V.5. Distribusi batuan basalt, diabas, gabro, dan piroksenit dari ofiolit Meratus-Bobaris di dalam diagram $\mathrm{Ni}-\mathrm{FeO}^{*}$ / $\mathrm{MgO} \ldots \ldots \ldots \ldots \ldots \ldots \ldots \ldots \ldots \ldots \ldots \ldots \ldots \ldots \ldots \ldots \ldots \ldots \ldots$

V.6. Distribusi batuan basalt dan gabro, dari ofiolit MeratusBobaris di dalam diagram V - Ti/1000 (Shervais, 1982) ..

V.7. Distribusi batuan basalt, diabas, gabro, piroksenit dan dunit dari ofiolit Meratus - Bobaris di dalam diagram Pecerillo \& Taylor (1976) ...................

V.8. Perajahan batuan basalt, diabas, gabro, dunit dan piroksenit, serpentinit dan peridotit piroksen Meratus -

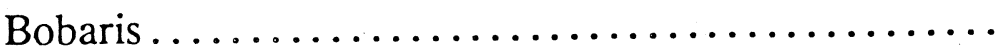

VI.1. Skenario genesis dan penempatan ofiolit Karangsam-

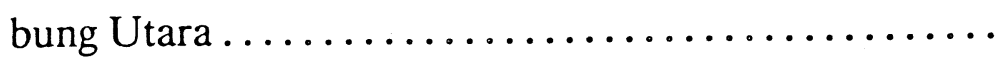

VI.2. Skenario genesis dan penempatan ofiolit Peg. MeratusBobaris

VI.3. Gambar detil penempatan ofiolit Karangsambung Utara (a) dan ofiolit Peg. Meratus - Bobaris (b) ...........

VI.4. Keadaan geologi daerah Luh Ulo pada waktu sekarang .

VI.5. Skenario perkembangan dari penyebaran batuan dasar (Pulau Jawa dan Kalimantan Timur). 
II.1. Singkapan gabro masif (a) yang seringkali memperlihatkan adanya bongkah-bongkah diabas (b). Perhatikan bintik-bintik putih fenokris plagioklas pada bongkah diabas.

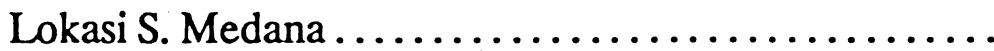

II.2. Singkapan gabro yang telah terubah dan terdeformasi. Perhatikan gejala breksiasi pada kedua foto serta banyaknya barik-barik kuarsa atau karbonat (putih) pada Foto II.2a \& barik epidot (kuning pucat) pada Foto II.2b.

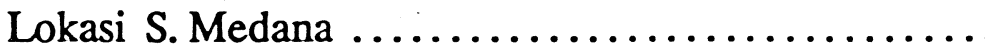

II.3. "Close up" dari singkapan gabro berbutir halus (a) dan gabro berbutir kasar (b). Perhatikan bercak-bercak putih dari mineral plagioklas dan piroksen berwarna hijau (Foto II.3b). Lokasi S. Medana ................

II.4. Singkapan diabas yang memperlihatkan adanya bongkah atau blok basalt (a); tidak jarang diketemukan singkapan yang terdiri dari percampuran antara diabas, gabro dan basalt (b). Lokasi S. Lokidang ................

II.5. Singkapan lava basalt berstruktur bantal yang sangat jelas terlihat pada foto II.5b. Lokasi S. Lokidang ...... .

II.6 Singkapan lava bantal terdeformasi yang dicirikan oleh gejala milonitisasi (a) serta barik-barik kuarsa atau karbonat berwarna putih yang saling memotong (b).

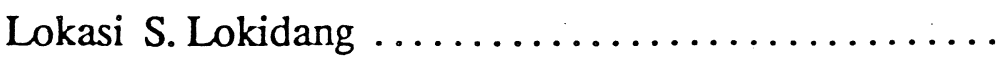


III.1. Keduanya adalah foto dari sayatan lersolit yang cukup segar. Batuan ini terdiri dari piroksen (warna putih keruh sampai kuning-kuning emas), dan olivin (warna merah jambu atau biru). Gejala serpentinisasi (kanan atas - kiri agak tengah) kadang-kadang teramati pada lersolit. Nikol bersilang .................................

III.2. Sayatan lersolit yang memperlihatkan adanya gejala $e x-$ solution pada mineral klinopiroksen. Nikol bersilang... .

III.3.a \& Sayatan gabro non kumulus, bertekstur ofitik sub ofitik

b. dengan variasi ukuran butir kasar sampai halus. Nikol bersilang...$\ldots \ldots \ldots \ldots \ldots \ldots \ldots \ldots \ldots \ldots \ldots \ldots$

III.3.c \& Sayatan gabro kumulus yang cukup segar, memperlihatd. kan perlapisan yang dibentuk oleh perselingan antara plagioklas (abu-abu, berkembar) dan piroksen (kuningkuning emas Foto $c$ ). Batuan yang sama dimana plagio klas sebagai kristal interkumulus telah terubah menjadi serisit (bersifat keruh). Sedangkan piroksen mewakili kristal kumulus di dalam sayatan gabro (Foto d.). Nikol

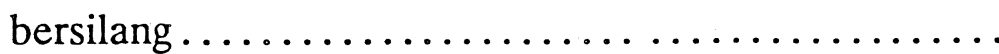

III.4. Sayatan gabro yang memperlihatkan rekristalisasi akibat pengubahan serta deformasi. Perhatikan adanya agregat prehnit mengisi retakan (a) atau mengganti sebagian plagioklas (b), Kehadiran karbonat berupa barik maupun bercak juga terlihat pada foto. Nikol bersilang .........

III.5. Sayatan diabas berbutir sedang dan dicirikan oleh tekstur 
ofitik/diabasik (foto a). Sedangkan foto b. memperlihatkan basalt berbutir lebih halus, bertekstur intergranular -intersertal. Nikol bersilang ....................

III.6. Sayatan diabas yang memperlihatkan gejala deformasi serta pengubahan. Perhatikan adanya barik-barik prehnit yang memotong batuan pada Foto III.6b. Nikol bersilang

III.7a. Sayatan dasit bertekstur porfiritik terdiri dari fenokris plagioklas (keruh) dan kuarsa (putih) tertanam di dalam masadasar sangat halus. Perhatikan fenokris plagioklas (kanan atas) yang telah mengalami proses albitisasi (barik-barik atau bercak putih). Nikol bersilang .....

III.7b. Sayatan kontak antara batulempung pasiran (kiri, warna coklat kekuningan) dengan dasit (kanan). Perhatikan adanya fragmen-fragmen felspar (putih keruh) dari dasit tercampur di dalam batulempung pasiran. Nikol ber-

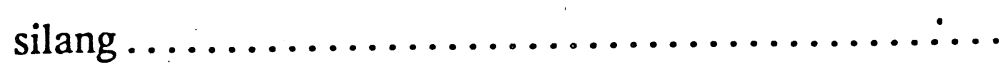




\section{DAFTAR LAMPIRAN}

Lampiran

Halaman

1. Tabel II.1. Umur absolut berdasarkan metoda K-Ar bebebeberapa batuan yang dipilih dari Karangsambung Utara . .

2. Tabel III.1a. Hasil mikroprob mineral serpentin dari batuan serpentinit (CD-49) daerah Karangsambung Utara .......

3. Tabel III.1b. Hasil analisis mikroprob serpentin dan $\mathrm{Mg}$ kromit dari batuan serpentinit (SL - 3B) Karangsambung

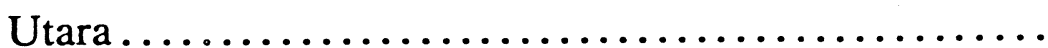

4. Tabel III.2. Hasil analisis mikroprob plagioklas, ilmenit, sfen, serta hornblenda batuan gabro (PS-6, CD-7) Karangsambung Utara $\ldots \ldots \ldots \ldots \ldots \ldots \ldots \ldots \ldots \ldots \ldots \ldots \ldots \ldots \ldots \ldots$

5. Tabel III.3. Hasil analisis mikroprob plagioklas, klorit, dan ilmenit batuan basalt (ST-69) Karangsambung Utara ......

6. Tabel III.4. Hasil analisis mikroprob piroksen dari gabro (CD-7) Karangsambung Utara ................

7. Tabel III.5. Hasil analisis mineral piroksen batuan gabro

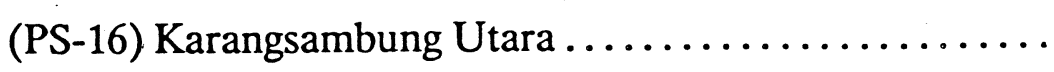

8. Tabel III.6. Hasil analisis mikroprob piroksen dari basalt

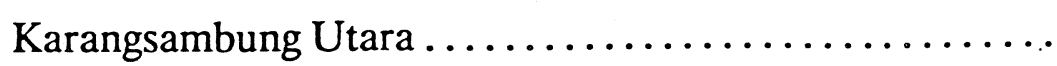

9. Tabel IV.1a. Hasil analisis kimia batuan basalt daerah Karangsambung Utara $\ldots \ldots \ldots \ldots \ldots \ldots \ldots \ldots$

10. Tabel IV.1b. Hasil analisis kimia batuan diabas, gabro dan serpentinit daerah Karangsambung Utara ............

11. Tabel IV.2. Hasil analisis UTL batuan basalt, diabas, gabro rijang dan kondrit komplek ofiolit Karangsambung Utara . .

12. Tabel IV.3. Variasi kadar unsur-unsur utama sebagai fungsi 
dari tingkat pengubahan.$\ldots \ldots \ldots \ldots \ldots \ldots \ldots \ldots$

13. Tabel V.1a: Hasil analisis kimia batuan basalt, diabas dan gabro dari ofiolit Meratus - Bobaris . ..............

14. Tabel V.1b. Hasil analisis kimia peridotit piroksen dari

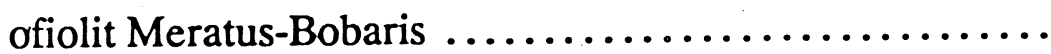

15. Tabel V.1c. Hasil analisis kimia batuan piroksenit, harsburgit, serpentinit dan dunit dari ofiolit Meratus -

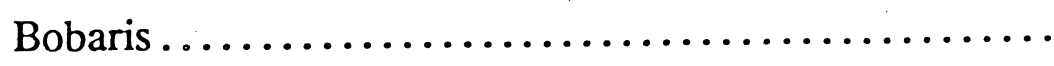

16. Foto 1. Bodin (boudin) batupasir yang terkepung di dalam batulempung tergerus kuat (pervasively sheared). Lokasi $\mathrm{K}$. Cacaban

17. Foto 2. Keratan/bongkah batupasir di dalam lempung bersisik (scaly clay) dari Formasi Karangsambung (a) dan Formasi Totogan (b). Lokasi K. Salak - Banjarsari (a) dan K. Luh Ulo - Totogan (b).....................

18. Foto 3. Sayatan batusabak sebagai matriks (a) dan bodin batupasir terrekristalisasi (b) dari komplek melange Luh

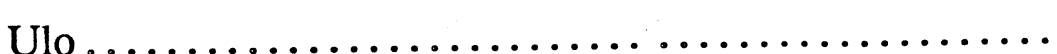

19. Foto 4. Sayatan batulempung sebagai matriks (a) dan keratan batupasir (b) Formasi Karangsambung. Perhatikan kehadiran cangkang fosil baik di dalam matriks maupun di

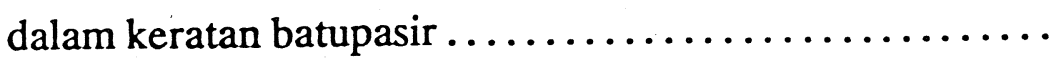

20. Foto 5. Sayatan batulempung menyerpih sebagai matriks (a) dan bongkkah batupasir (b) dari Formasi Totogan ......

21. Daftar istilah dan singkatan .................. 176

22. Daftar riwayat hidup ..................... 181 


\section{BAB I}

\section{PENDAHULUAN}

Penyebaran ofiolit di Indonesia dapat dilihat pada Gambar I.1 yang mana sebagian dari komplek tersebut masih perlu diteliti secara rinci. Dari gambar tersebut terlihat penyebaran ofiolit yang cukup luas di Sumatra, Kalimantan Tenggara, Sulawesi, serta di daerah Kep. Maluku - Halmahera. Penyebaran ofiolit yang cukup luas, terutama di Indonesia Timur, menyebabkan banyak geologiwan dari seluruh dunia datang ke Indonesia untuk meneliti secara lebih terinci komplek-komplek tersebut baik untuk ilmu pengetahuan secara murni, maupun dalam kaitannya dengan segi ekonomi.

Penyelidikan ofiolit secara khusus dengan dasar pemikiran teori tektonik global masih belum banyak dilakukan. Beberapa penelitian global secara terinci yang pernah dilakukan antara lain oleh Soeria Atmadja dkk., 1974; Soeria Atmadja dan Sukamto 1979; Soeria Atmadja, 1981; dan Soeria Atmadja dkk., 1988, berturutturut di daerah busur timur Sulawesi, Kep. Talaud, Kep. Halmahera dan P. Obi. Silaban (1975), Rachman (1977), Panigoro (1981), serta Permana (1985) masing-masing meneliti ofiolit berturut-turut di daerah Karangsambung Utara, Luh Ulo - Jawa Tengah, Karakelang Selatan (Kep. Talaud), Ciletuh (Jawa Barat), serta P. Obi (Maluku). Satu-satunya proyek penelitian ofiolit yang cukup regional jangkauannya adalah proyek penelitian ofiolit dalam kaitannya dengan potensi endapan mineral bijihnya, yang dilakukan oleh Bundesanstalt fur Geowissenschaften und Rohstoffe (Jerman Barat) yang bekerja sama dengan Direktorat Sumber Daya Mineral. Proyek penelitian ini berlangsung selama tahun 1980 - 1986 dengan lebih mengutamakan penelitian di daerah Indonesia Timur (Sulawesi, Kep. Maluku - Halmahera) dan Kalimantan. Penelitian penulis diharapkan dapat memberi sumbangan yang dapat melengkapi data tentang ofiolit di Indonesia, khususnya mengenai genesis (mencakup tipe ofiolit) serta masalah penempatan ofiolit Karangsambung Utara. Disamping hal tersebut penelitian 


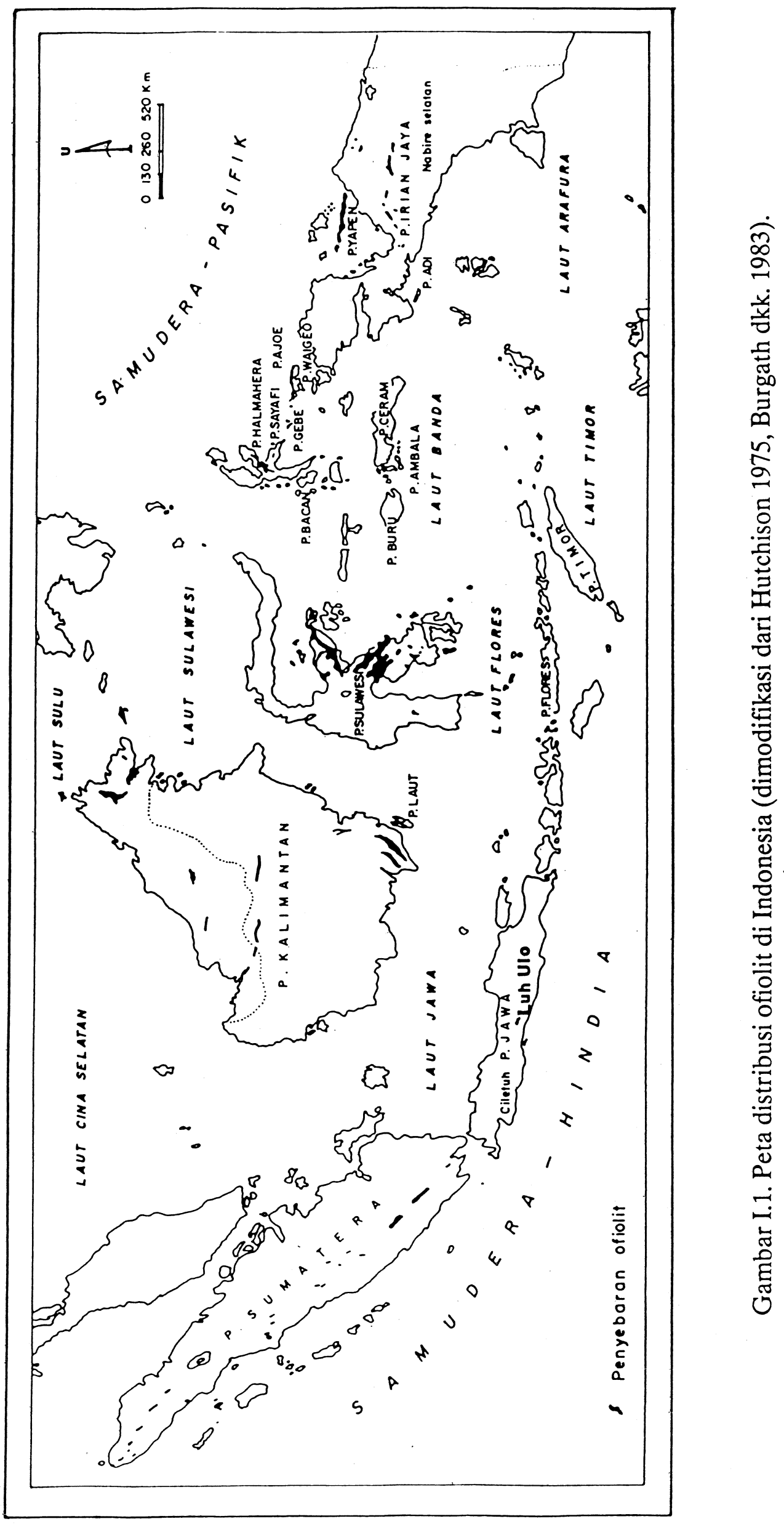


ofiolit secara keseluruhan mempunyai arti ekonomis tersendiri bagi Indonesia. Sebagai contoh laterit nikel (yang merupakan hasil pelapukan dari batuan ultramafis) di Sulawesi Timur (Soroako dan Pomalaa) serta di P. Gebe, merupakan cadangan yang cukup potensial di dunia. Di komplek ofiolit juga diharapkan diketemukan endapan bijih kromit dan platina, yaitu dua komoditi yang langka di dunia dan menjadi incaran perusahaan tambang internasional saat ini, begitu pula kemungkinan endapan yang mengandung beberapa unsur jejak yang penting seperti osmium, iridium serta vanadium. Disamping juga adanya kemungkinan endapan-endapan non logam lainnya seperti asbes, magnesit, batu hias serta serpentin (yang dapat dipakai sebagai pencampur bahan pupuk fosfat). Sebagai bahan perbandingan juga dilampirkan peta distribusi ofiolit di seluruh dunia (Gambar I.2). Beberapa contoh komplek ofiolit yang cukup terkenal di dunia akan dijadikan bahan acuan untuk penulisan disertasi ini antara lain yang terdapat di Oman, Yunani (Pindos), dan Papua Niugini. Sedangkan ofiolit di Pegunungan Meratus Bobaris yang terdapat di Kalimantan Tenggara dipilih sebagai bahan pembanding mengingat adanya keterkaitan dengan ofiolit Karangsambung dalam sejarah/evolusi tektonik wilayah Indonesia Barat pada jaman Kapur.

\subsection{Latar belakang dan permasalahan}

Di dalam konsepsi ilmu geologi dua dasawarsa ini terjadi perkembangan yang sangat radikal pada pola pemikirannya; yang terwujud sebagai konsep tektonik global. Konsep ini berkembang sangat pesat dan menghasilkan perubahan yang sangat penting di dalam setiap pembahasan sifat-sifat tektonik di dalam jalur-jalur orogen.

Secara singkat dapat diuraikan bahwa konsep tektonik global didasarkan kepada anggapan bahwa semua bagian dari kerakbumi merupakan lempenglempeng yang tegar; masing-masing lempeng bergerak menjauh dari pusatnya yang berupa pemunculan-pemunculan di tengah samudera dan menghilang dengan cara menyesar ke bawah lempeng lainnya melalui lajur tunjaman, atau bergeser satu terhadap lainnya dengan dibatasi oleh sesar mendatar dengan kecepatan relatif 


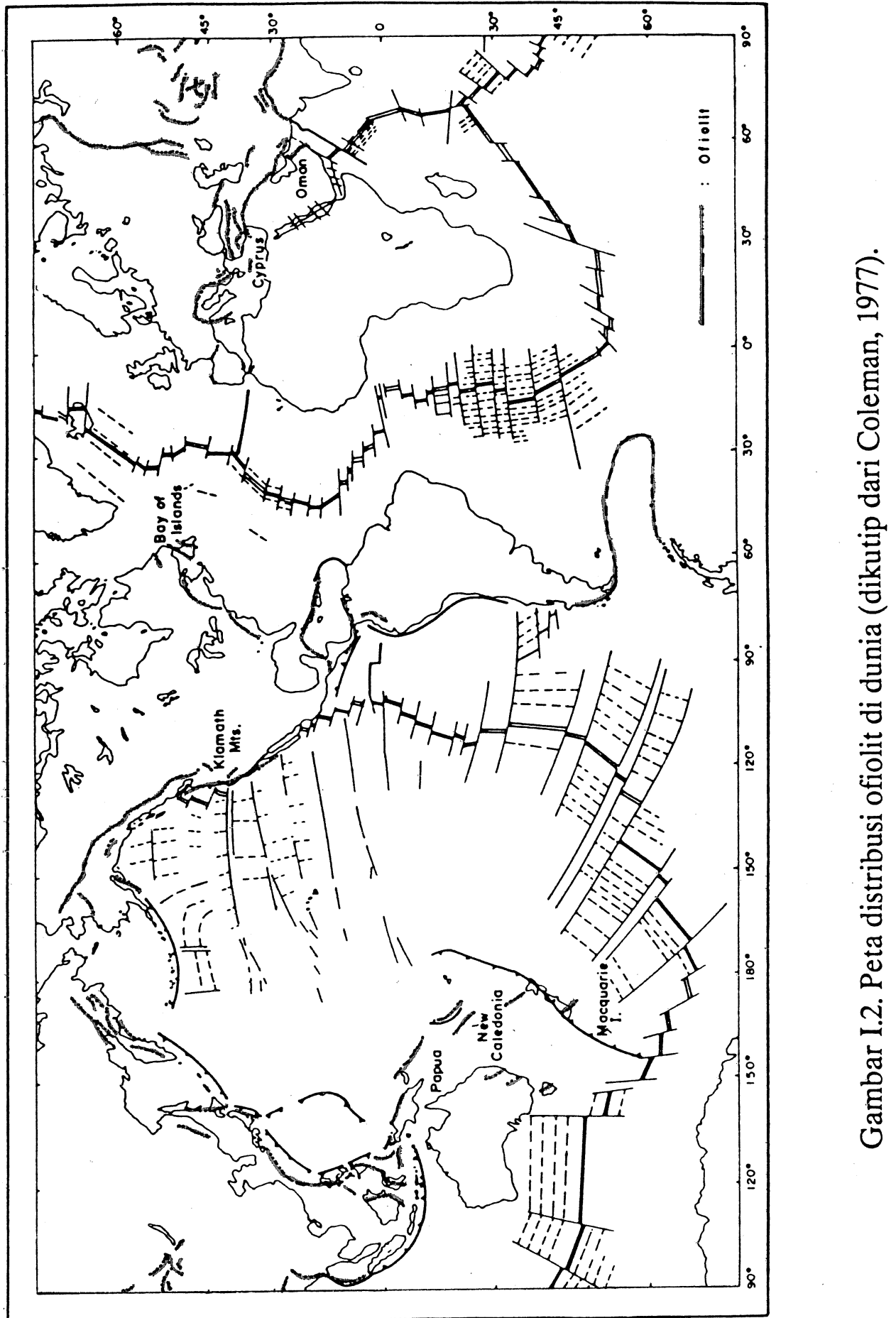


paling sedikit $10 \mathrm{~cm}$ per tahunnya atau $100 \mathrm{~km}$ per juta tahun. Batas-batas lempeng dapat berupa punggung tengah samudera (mid-oceanic ridge), sesar-sesar mendatar, serta palung-palung laut dalam. Batas lempeng yang disebut paling akhir merupakan tempat dimana terjadi benturan antara dua lempeng yang berbeda. Benturan ini mengakibatkan salah satu lempeng akan ditekuk dan didesak ke bawah, menyusup ke dalam lapisan mantel; daerah ini yang dikenal sebagai lajur tunjaman. Apabila benturan terjadi antara lempeng benua dan samudera maka pada lajur tunjaman akan terkumpul kepingan-kepingan yang berasal dari samudera dan benua (membentuk komplek melange); kepingan-kepingan yang berasal dari lempeng samudera merupakan himpunan batuan yang berkomposisi mafis-ultramafis, dikenal sebagai ofiolit. Dengan demikian dapat disimpulkan juga bahwa ofiolit merupakan salah satu fosil batas lempeng purba, meskipun terbukti pula bahwa ofiolit dapat terbentuk di dalam berbagai macam lajur tektonik yang berbeda, baik pada atau dekat batas pertemuan lempeng. Bahkan ofiolit juga dapat terbentuk pada suatu tempat yang tidak ada kaitannya dengan batas lempeng. Pada hakekatnya permasalahan ofiolit merupakan suatu permasalahan tersendiri yang cukup rumit

\subsection{Ofiolit dan permasalahannya}

Istilah ofiolit itu sendiri telah dijelaskan secara singkat oleh Coleman (1977). Pertamakali istilah ini dicetuskan oleh Brongniart, 1827 (dikutip dari Mc. Call, 1983); berasal dari kata ophi dalam bahasa Yunani yang dalam bahasa Inggris berarti snake atau serpent atau berarti ular di dalam bahasa Indonesia. Ofiolit digunakan untuk penamaan batuan yang berwarna kehijauan berbintik hitam agak mengkilat seperti ular; dalam hal ini yang dimaksud adalah batuan serpentinit (berwarna hijau kehitaman).

Selanjutnya Steinmann (1927) dengan Steinmann Trinity-nya mengembangkan istilah ofiolit yang semula merupakan nama untuk sejenis batuan menjadi istilah untuk sekelompok batuan yang terdiri dari serpentinit (peridotit), diabas, serta spilit. Himpunan batuan peridotit, diabas serta spilit ini seringkali berasosiasi 
dengan sedimen laut dalam (antara lain rijang radiolaria). Konsep tersebut kemudian berkembang dengan adanya anggapan bahwa pembentukan himpunan batuan tersebut erat hubungannnya dengan pembentukan suatu geosinklin (merupakan kegiatan magmatis pada awal pembentukan geosinklin).

Sejalan dengan berkembangnya teori tektonik lempeng di tahun 60-an, banyak pendapat-pendapat tentang ofiolit yang didasarkan kepada konsep geosinklin tersebut dievaluasi kembali dengan pola pemikiran tektonik lempeng. Sebagai salah satu contoh adalah batuan dari pegunungan Alpen yang berwarna hijau (serpentinit) diinterpretasikan kembali sebagai kepingan-kepingan dari kerak samudera dan mantel yang tersugu pada batas tepian daratan (Gass, 1967; Coleman, 1971; Dewey \& Bird, 1971; Davies, 1971; Moore \& Vine, 1971; serta Church, 1972; diambil dari Mc Call, 1983). Definisi ofiolit kemudian dirinci kembali dan terwujud di dalam Penrose Field Conference di tahun 1972 yang menyimpulkan bahwa ofiolit merupakan sekelompok batuan yang berkomposisi mafis-ultramafis; secara lengkap sekuen dari bawah keatas berturut-turut terdiri dari (1) komplek batuan ultramafis (dunit, harsburgit, dan lersolit) yang biasanya memperlihatkan kemas tektonik dan terserpentinisasi, (2) komplek gabro yang umumnya bertekstur kumulus (mencakup peridotit kumulus serta piroksenit); biasanya mengalami deformasi tidak sekuat komplek ultramafis, berikutnya berturutturut adalah (3) komplek retas berlapis berkomposisi mafis dan (4) komplek batuan volkanis berkomposisi mafis bertekstur bantal. Ofiolit berasosiasi dengan batuan sedimen mencakup rijang berlapis (serpih serta batugamping), ataupun dengan batuan terobosan dan lelehan yang bersifat lebih asam. Lebih lanjut dinyatakan bahwa komplek ofiolit juga dapat dijumpai secara tidak lengkap, terpisah-pisah maupun termetamorfosis. Permasalahan ofiolit dewasa ini berkembang sampai kepada anggapan bahwa ofiolit dapat terbentuk pada berbagai lingkungan samudera, busur dan di cekungan tepi (marginal basin).

Dari penjelasan tersebut di atas dapat disimpulkan bahwa permasalahan ofiolit mencakup masalah-masalah sebagai berikut : 
a. Macam ofiolit ditinjau dari segi himpunan batuannya; apakah lengkap (complete), terpisah-pisah (dismembered), tidak lengkap (incomplete) atau termetamorfosis (metamorphosed).

b. Pola kimia dari batuan volkanis, hipabisal, serta batuan plutonik yang tercakup di dalam komplek ofiolit untuk mempelajari evolusi serta jenis magma primernya.

c. Kemungkinan hubungan genetis antar batuan mafis-ultramafis yang diketemukan di satu komplek ofiolit.

d. Lingkungan tektonik pembentukan ofiolit apabila himpunan batuan mafis-ultramafis tersebut ko genetis.

e. Mekanisme penempatannya (emplacement).

\subsection{Masalah ofiolit di Luh Ulo - Jawa Tengah.}

Daerah Luh Ulo, Jawa Tengah (Gambar I.3) yang meliputi luas daerah lebih kurang $30 \times 10 \mathrm{~km}^{2}$, merupakan salah satu dari dua daerah di Jawa lainnya yaitu di Ciletuh Jawa Barat, dimana diketemukan komplek melange (Hehuwat, 1986). Di dalam komplek melange tersebut, tepatnya di daerah Karangsambung Utara diketemukan singkapan dari himpunan batuan berkomposisi mafis-ultramafis (ofiolit) dengan luas daerah lebih kurang $10 \times 3,5 \mathrm{~km}^{2}$, berarah umum timurlaut barat daya. Ofiolit di daerah ini belum pernah diteliti secara khusus dan rinci. Penulis (1973) telah meneliti terbatas pada lava basaltnya saja, terutama dalam hubungannya dengan batugamping-rijang yang seringkali diketemukan bersamaan; dalam pembahasannya masih digunakan teori geosinklin. Sedangkan penelitian berikutnya di daerah ofiolit Karangsambung Utara dilakukan oleh Silaban (1975) dengan konsep tektonik global yang sebelumnya telah diterapkan oleh Sukendar (1974). Di dalam salah satu pembahasannya Sukendar beranggapan antara lain bahwa kelompok ofiolit di daerah Karangsambung Utara (Luh Ulo) merupakan kepingan dari lempeng / kerak Samudera Hindia yang terseret dan kemudian tersugu di dalam palung pada waktu terjadi benturan antara lempeng Samudera Hindia tersebut dengan lempeng Eurasia pada jaman Kapur Atas hingga 


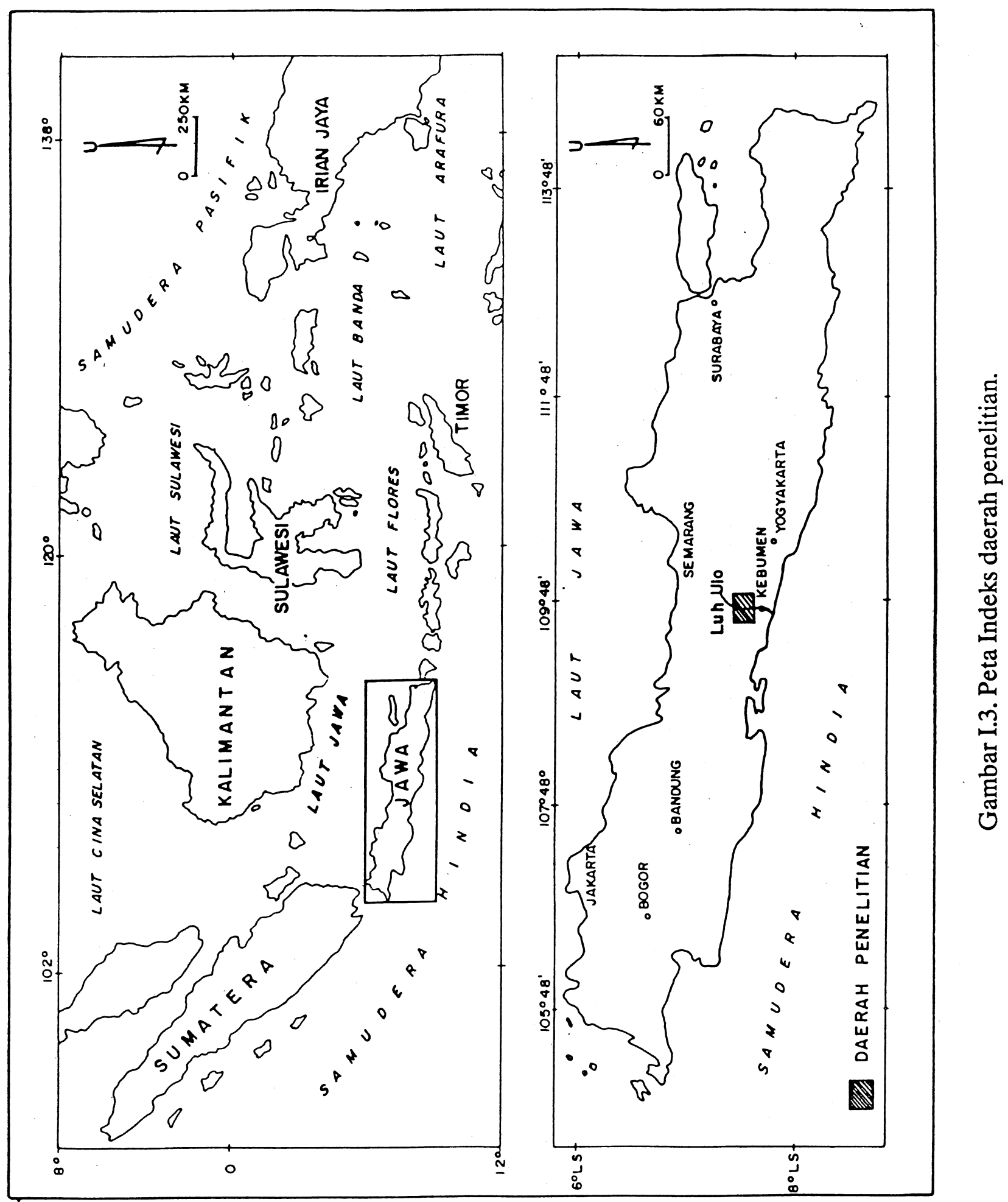


Paleosen. Khusus dalam kaitannya dengan ofiolit di daerah Luh Ulo, pernyataan ini memerlukan beberapa pembuktian; terutama dari segi petrologi dan pola kimianya, mengingat adanya beberapa masalah pokok yang harus dipecahkan di dalam setiap pembahasan tentang ofiolit. Permasalahan tersebut meliputi beberapa hal sebagai berikut :

1. Masalah genesis ofiolit daerah Karangsambung Utara mencakup masalah hubungan antar batuan dari segi petrologi dan pola kimianya (ko genetis atau tidak). Hal ini sangat penting untuk dipecahkan, karena tidak selamanya himpunan batuan mafis-ultramafis yang dijumpai dalam suatu daerah yang berdekatan akan memperlihatkan hubungan ko genetis. Sedangkan suatu himpunan batuan mafis-ultramafis dinyatakan sebagai satu komplek ofiolit apabila masing-masing batuan berkaitan satu dengan lainnya dalam hal genesisnya atau ko genetis (Allegre et al, in prep.).

2. Jenis himpunan batuan yang terdapat di dalamnya; hal ini berkaitan dengan penggolongan ofiolit didasarkan kepada macam batuan yang ada (lengkap, tidak lengkap, terpisah-pisah, atau termetamorfosis). Begitu juga dengan mempelajari mengenai batuan volkanisnya dapat ditentukan tipe ofiolit daerah ini berdasarkan klasifikasi yang dibuat oleh Miyashiro (1975).

3. Lingkungan tektonik pembentukan ofiolit serta mekanisme penempatannya.

\subsection{Tujuan Penelitian}

Untuk memecahkan permasalahan ofiolit di daerah ini diperlukan penelitian secara rinci mengenai genesisnya, terutama dari segi petrologi dan pola kimianya yang merupakan tujuan dari penelitian. Selain daripada itu penelitian ini juga bertujuan untuk menyempurnakan ataupun memperbaiki model penempatannya yang telah ada. Sebagai studi perbandingan akan dibahas ofiolit daerah Peg. Meratus-Bobaris (Kalimantan Tenggara) yang dianggap berkaitan dalam hal tatanan tektoniknya. Dengan demikian diharapkan akan menghasilkan data guna melengkapi informasi tentang perkembangan geologi dari daerah Luh Ulo khususnya, dan dari busur kepulauan Sunda pada umumnya. Lebih 
lanjut diharapkan model genesis ofiolit tersebut dapat dipakai sebagai salah satu model pembanding bagi penelitian ofiolit lainnya di Indonesia. Dengan semakin banyaknya informasi tentang ofiolit secara rinci maka diharapkan berbagai rekonstruksi paleogeografi di berbagai tempat di Indonesia dari jaman ke jaman dapat diinterpretasikan secara lebih jelas. Dari segi ekonomi mengingat himpunan batuan ini erat hubungannya dengan potensi beberapa endapan mineral logam (nikel, platina, kromit) maupun non logam (magnesit, asbes, batu hias/ornamental stone, dan bahan pupuk) maka diharapkan dengan penyelidikan ofiolit di daerah Karangsambung Utara ini akan menambah data daerah-daerah yang mungkin potensial.

\subsection{Metoda Penelitian}

Pemecahan permasalahan mengenai genesis ofiolit di daerah Karangsambung Utara ini memerlukan penyelidikan di lapangan dan penelitian di laboratorium. Penelitian di laboratorium terhadap conto-conto batuan yang diperoleh dari pengerjaan di lapangan mencakup analisis petrografi dan kimia. Analisis secara petrografi dilakukan di laboratorium Petrologi \& Geologi Ekonomi, Jurusan Teknik Geologi ITB, sedangkan untuk analisis kimiawi batuan dilakukan di Perancis yaitu di Laboratoire de Geochimie et Cosmochimie, Universite de Paris VI - Paris, di Laboratoire de petrologie de CNEXO - COB, serta di Laboratoire de petrologie, Universite de Bretagne Occidentale, Brest, berturut-turut untuk analisis unsur tanah langka, unsur utama dan unsur jejak batuan secara keseluruhan, serta analisis mikroprob; yang disebut terakhir ini dilakukan oleh Maury dan Yuwono, sedangkan pengerjaan analisis kimia lainnya yang disebutkan terdahulu dilakukan sendiri dalam kesempatan memperoleh beasiswa selama dua tahun tiga bulan di Perancis (April 1981 - Juli 1983).

\subsubsection{Metode Lapangan}

Penyelidikan lapangan di daerah Karangsambung Utara dilakukan antara tahun 1978 hingga tahun 1980, setiap kali selama beberapa minggu. Setelah itu 
dilakukan pengecekan lapangan terakhir pada tahun 1987. Pekerjaan lapangan terutama ditujukan kepada pemetaan rinci komplek batuan mafis ultramafis dengan membuat lintasan melalui sungai-sungai (Pakuruhan, Curugdawa, Medana, Lokidang dan Parakansubah) yang berarah utara-selatan yang memotong hampir tegak lurus arah penyebaran komplek tersebut. Untuk penyelidikan lapangan digunakan peta topografi Jawa Tengah lembar 67 l, k, dan g yang berskala $1: 25.000$, dengan memperhatikan hal-hal sebagai berikut :

a. Macam dan hubungan masing-masing batuan yang dijumpai.

b. Pengamatan singkapan (mencakup struktur dan ciri-ciri litologi) dilakukan secara sistematis pada setiap lokasi berjarak masing-masing 25 meter, dan juga pada lokasi dimana terdapat perubahan litologi.

c. Pengambilan conto batuan yang segar, yang mewakili setiap jenis batuan. Hal ini perlu dikemukakan karena conto batuan yang segar agak sulit diperoleh, terutama pada singkapan batuan mafis ultramafis yang umumnya mudah teroksidasi akibat komposisinya yang banyak mengandung besi; sedangkan conto batuan yang segar sangat diperlukan untuk memperoleh hasil yang akurat dalam analisis selanjutnya di laboratorium seperti analisis kimia dan penarikhan umur batuan.

\subsubsection{Metode Laboratorium}

Sejumlah lebih kurang 200 conto batuan segar yang diambil di lapangan selanjutnya dianalisis secara megaskopis dan juga mikroskopis; analisis yang disebutkan terakhir ini sangat diperlukan untuk menyeleksi kembali conto-conto batuan untuk dianalisis kimia maupun analisis lanjut lainnya.

\subsubsection{Analisis petrografi}

Analisis petrografi merupakan salah satu analisis laboratorium yang pertama kali dilakukan terhadap conto batuan yang diperoleh di lapangan. Conto batuan yang akan dianalisis terlebih dahulu harus disayat dengan ketebalan $0,03 \mathrm{~mm}$ untuk dapat diamati di bawah mikroskop polarisasi. Dengan melakukan analisis 
petrografi seleksi terhadap conto batuan untuk analisis lebih lanjut dapat lebih akurat. Disamping itu, analisis petrografi juga digunakan untuk mempelajari tekstur serta mineralogi batuan, dengan demikian batuan dapat ditentukan jenisnya berdasarkan klasifikasi yang dipilih; proses-proses sekunder lainnya (seperti proses pengubahan dan deformasi) yang terdapat dalam batuan juga dapat dipelajari dengan analisis mikroskopis ini. Data yang diperoleh dari analisis petrografi merupakan informasi awal yang sangat diperlukan untuk analisis laboratorium selanjutnya.

\subsubsection{Metode mass spectrometric isotope dilution}

Beberapa metode dikenal untuk menganalisis unsur tanah langka diantaranya metode pendar sinar X (X-ray fluorescence), aktifasi netron (neutron activation), serta spektrometri masa dengan pengenceran isotop (mass spectrometric isotope dilution). Metode pengenceran isotop merupakan metode yang paling baik dan teliti terutama untuk menganalisa 10 (sepuluh) unsur tanah langka (rare earth elements) sekaligus dari 14 (empat belas) unsur tanah langka secara lebih cepat dan teliti. Manipulasi kimianya sangat tertentu dan untuk ini diperlukan proses pemisahan unsur-unsur secara teliti yang mana proses preparasi kimia merupakan faktor yang penting untuk memperoleh hasil yang optimal. Dasar penggunaan metode analisis spektrometri masa dengan pengenceran isotop dimaksudkan untuk determinasi komposisi isotop dari suatu unsur dengan spektrometer masa, yang mana untuk preparasi contonya (pemisahan ke dalam fraksifraksi untuk dianalisis) digunakan metode kimia pengenceran isotop (Gambar I.4).

Prinsip pengenceran isotop adalah penambahan sejumlah komposisi isotop batuan yang sudah diketahui (disebut tracer atau spike) ke dalam sejumlah unsur dari batuan, yang hasilnya berupa perubahan di dalam komposisi isotopik; hasil tersebut dianalisis dengan spektrometer masa. Untuk memperoleh konsentrasi dari unsur termaksud yang dianalisis, digunakan rumus sebagai berikut :

$$
C x=\frac{\left(\beta_{1}-r\right) \cdot q \cdot P_{s} \cdot M_{s}}{r-\alpha_{1} \cdot P \cdot P_{E} \cdot M_{S}}
$$


dimana : Cx adalah konsentrasi dalam batuan

$\beta_{1}$ S2/S1 merupakan perbandingan isotop dari tracer

$\alpha_{1} \quad X_{2} / X_{1}$ adalah perbandingan isotop nomal dalam batuan

$r=a / b$ perbandingan isotop hasil pencampuran tracer dan isotop normal dalam batuan

$\mathrm{q}=\quad$ prosentase isotop $\mathrm{m}_{1}$ dalam tracer

Ps $=$ berat larutan yang mengandung tracer

$\mathrm{M}_{\mathbf{x}}=$ berat unsur normal

$\mathrm{M}_{\mathrm{s}}=$ berat tracer yang digunakan

$\mathrm{PE}_{\mathrm{E}}=$ berat conto batuan yang digunakan $(50-100 \mathrm{mg})$

$\mathrm{CS}=$ konsentrasi unsur tracer dalam larutan

Prosedur preparasi conto untuk analisis unsur tanah langka dengan pengenceran isotop dapat dilihat pada Gambar I.5.

\subsubsection{Metode pendar sinar X (X-ray fluorescence)}

Metode analisis dengan pendar sinar X sudah cukup lama dikenal, dan sudah merupakan salah satu metode analisis kimia yang secara rutin digunakan di dalam menganalisis unsur utama maupun unsur jejak di dalam batuan (Ahrens, 1960). Prinsip analisis pendar sinar $\mathrm{X}$ adalah penembakan elektron kulit dalam suatu unsur dengan sinar $\mathrm{X}$ sehingga elektron tersebut keluar dengan mengeluarkan pendar sinar X. Pendar sinar X yang dikeluarkan mempunyai panjang gelombang tertentu yang merupakan karakteristik dari unsur yang dianalisis. Sedangkan kadar dari unsur yang dianalisis merupakan fungsi dari intensitas pendar sinar yang dihasilkan. Salah satu faedah dari metode pendar sinar X ini mampu menganalisis sejumlah unsur-unsur tertentu ketelitian cukup tinggi dalam waktu yang relatif singkat. Conto yang akan dianalisis unsur-unsurnya cukup dilebur dengan litium borat sebagai fluks.

\subsubsection{Metode analisis mikroprob}

Salah satu metode analisis lain yang digunakan adalah determinasi mineral 

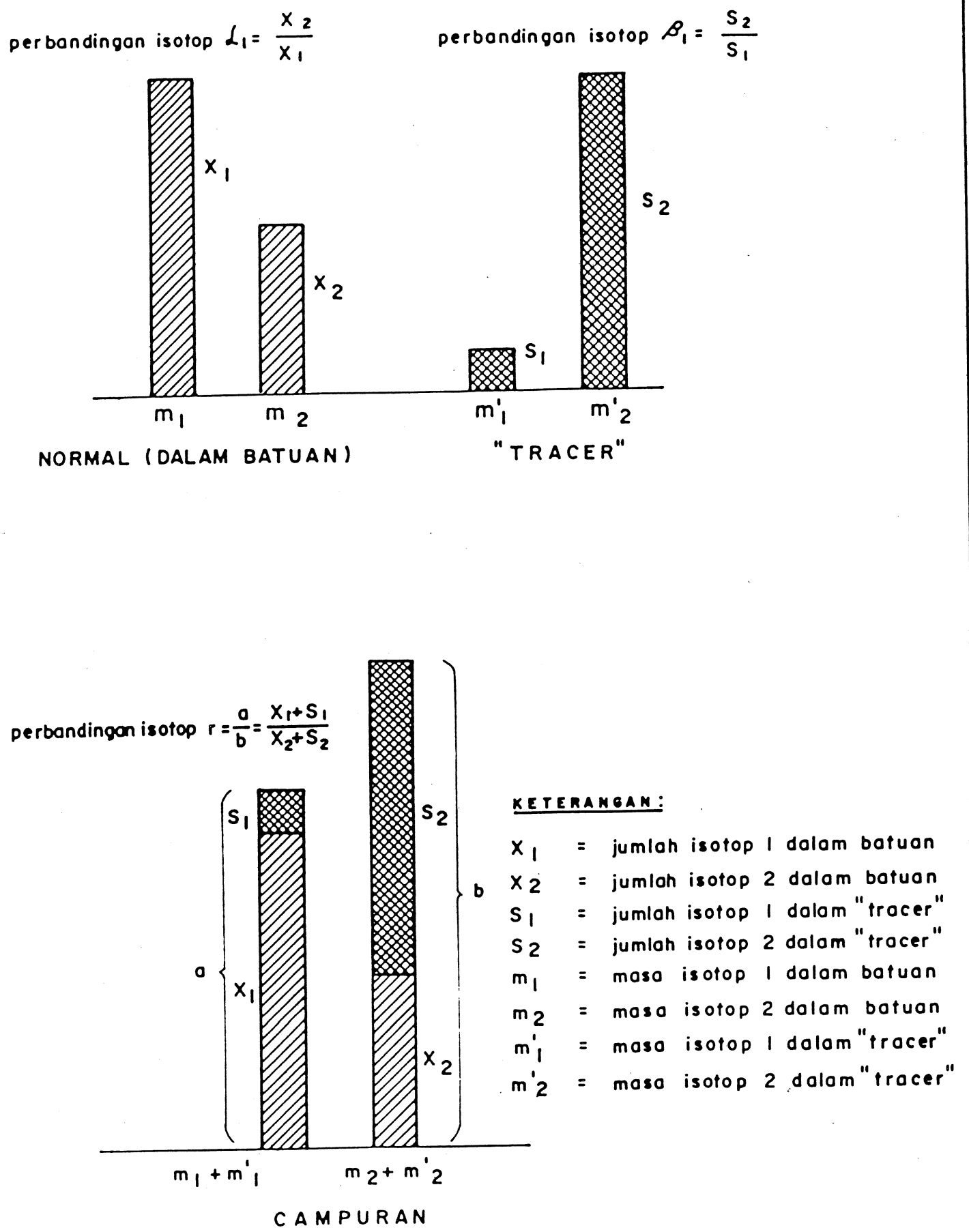

Gambar I.4. Pengenceran isotopik. 


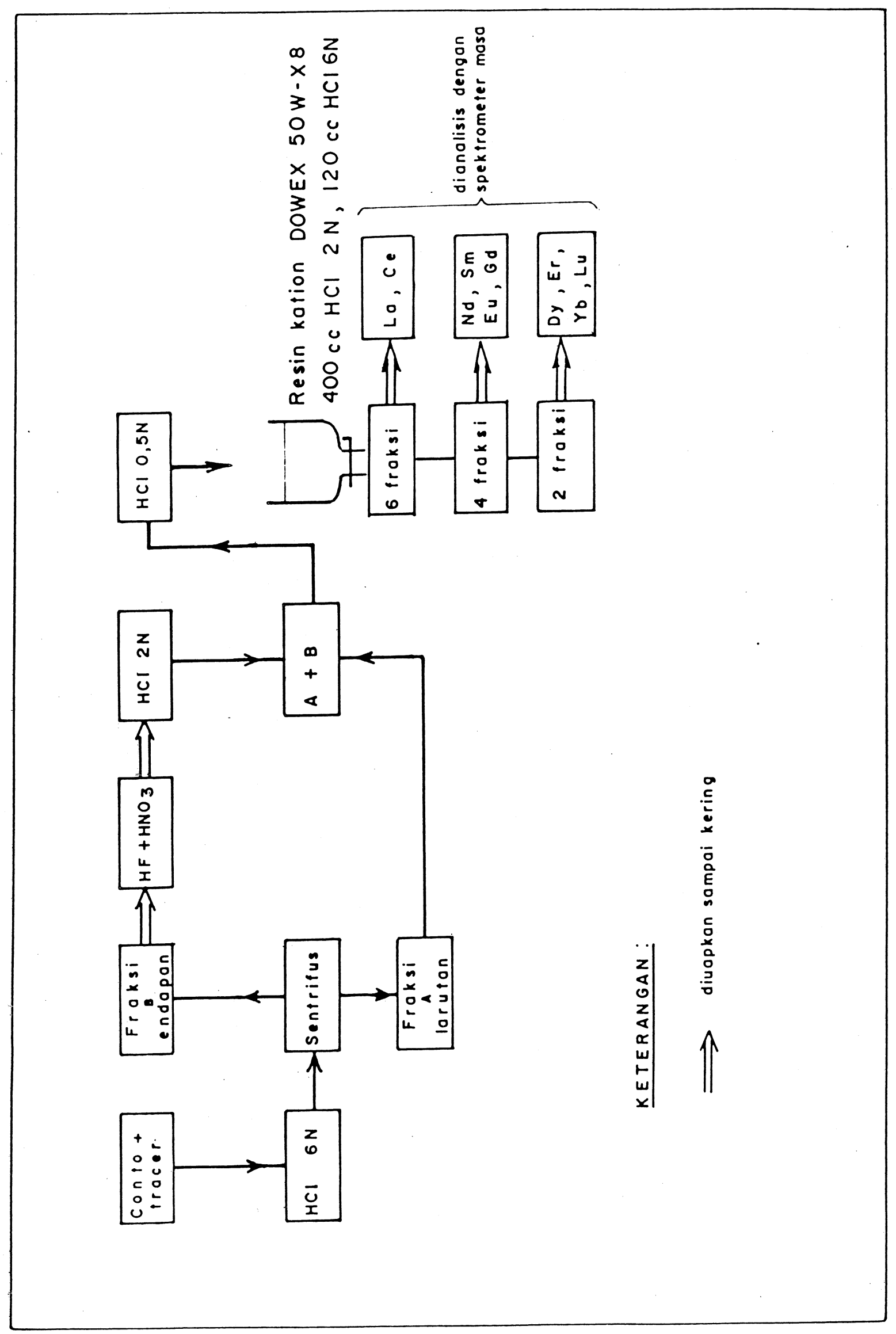

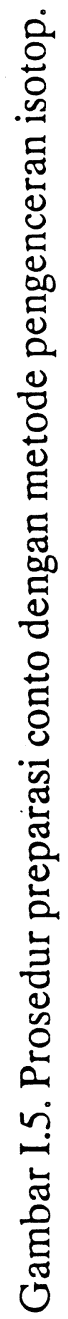


dengan cara mikroprob. Prinsip analisis mikroprob adalah penembakan elektron kulit dalam unsur dengan sinar $\mathrm{X}$ sehingga elektron tersebut akan keluar yang disertai sinar dengan panjang gelombang tertentu yang karakteristik untuk unsur tersebut; untuk ini diperlukan sayatan dengan ketebalan lebih kurang 0,05 mm. Untuk menentukan komposisi kimia beberapa mineral penting dari conto batuan himpunan ofiolit daerah penyelidikan digunakan alat microsonde Ouest dengan kondisi kerja sebagai berikut :

- $\quad$ tekanan akselerasi $15 \mathrm{Kv}$

- $\quad$ intensitas $15 \mathrm{nV}$

- waktu analisis : 3 (tiga) detik untuk analisis pendahuluan (semi kuantitatif), 3 (tiga) detik berikutnya untuk analisis kuantitatif (untuk menentukan prosentasenya).

\subsubsection{Metode pentarikhan radiometri K-Ar}

Guna mengetahui umur atau kedudukan stratigrafi himpunan batuan yang tercakup di dalam ofiolit daerah penyelidikan (basalt dan diabas) serta batuanbatuan lain yang ada hubungannya dalam hal genetis (termasuk dasit serta sekis mika) digunakan metode pentarikhan radiometri dengan cara $\mathrm{K}$-Ar yang dilakukan oleh H. Bellon di laboratoire de geochimie, Universite de Bretagne Occidentale, Brest.

Metode pentarikhan radiometri K-Ar didasarkan pada asumsi bahwa mineral maupun batuan yang akan dianalisis mengandung kalium dengan berbagai macam isotopnya; salah satu diantaranya adalah ${ }^{40} \mathrm{~K}$ yang bersifat radioaktif. Isotop ${ }^{40} \mathrm{~K}$ akan mengalami peluruhan (decay) menjadi ${ }^{40} \mathrm{Ar}$ dengan cara menampung elektron dengan waktu paruh ( half-life) yang diperlukan yaitu $\mathrm{t}^{1 / 2}=1,30 \times 10^{9}$ tahun (konstanta luruhan : $\quad=0,584 \times 10^{-10}$ per tahun). Reaksi peluruhan dari ${ }^{40} \mathrm{~K}$ menjadi ${ }^{40} \mathrm{Ar}$ merupakan reaksi kinetis tingkat pertama, dengan demikian umur batuan dapat ditentukan berdasarkan rumus sebagai berikut :

$$
\mathrm{t}=4154,04 \log 1+142,69{ }^{40} \mathrm{Ar} / \mathrm{K}
$$


dimana :

$\mathrm{t}=$ umur batuan yang dicari (dalam juta tahun)

${ }^{40} \mathrm{Ar}$ kadar isotop ${ }^{40} \mathrm{Ar}$ yang ditentukan dengan analisis kimia basah (wet chemical analysis)

$\mathrm{K}=$ kadar kalium yang dianalisis dengan spektrografi masa.

\subsubsection{Studi perbandingan}

Untuk studi perbandingan telah dikumpulkan data hasil analisis kimia ofiolit dari pegunungan Meratus dan Bobaris di Kalimantan Tenggara yang secara regional dianggap berkaitan dengan ofiolit daerah penyelidikan, dengan mengutip dari tulisan-tulisan maupun diperoleh secara komunikasi langsung dengan geologiwan yang melakukan penelitian di daerah tersebut (merupakan data yang belum diolah). Untuk keperluan tersebut telah dilakukan peninjauan lapangan selama seminggu pada tahun 1985 di beberapa lokasi antara lain daerah Awangbangkal, Pelaihari, dan Bukit Besar bersama sama dengan beberapa geologiwan dari Direktorat Sumber Daya Mineral (Ir. Umi Kuntjara, Ir. H.R.W. Simanjuntak, Ir. Harmanto), dan dari BGR - Jerman Barat (DR. K.P. Burgath \& Dipl. Ing. M. Klimansky). 


\section{BAB II}

\section{TATANAN TEKTONIK REGIONAL}

Penelitian petrologi suatu daerah, baik secara lokal maupun regional tidak terlepas kaitannya dengan masalah tektonik / struktur geologi daerah tersebut. Terutama apabila daerah yang diteliti telah mengalami deformasi sehingga mengakibatkan hubungan antara masing-masing satuan batuan sulit dikenali. Keadaan geologi semacam ini teramati antara lain di daerah Luh Ulo, Jawa Tengah yang dikenal sebagai kawasan lajur penunjaman purba (Sukendar, 1974).

\subsection{Kerangka tektonik pulau Jawa}

Pulau Jawa yang merupakan bagian dari Busur Sunda Barat adalah suatu contoh klasik sistem pertumbukan antar lempeng. Sejalan dengan perkembangan hipotesa tektonik lempeng, penerapan dan pengkajian konsep telah juga diterapkan di kawasan P. Jawa. Diantaranya adalah Sukendar (1974) yang telah membahas secara global perkembangan tektonik Pulau Jawa dengan memakai daerah Luh Ulo, Jawa Tengah, sebagai acuan penelitian; begitu pula Soejono (1985) telah membahas dalam kaitan perkembangan tektonostratigrafi di Jawa Barat.

Perkembangan tektonik pulau Jawa dapat direkonstruksi untuk kurun Kapur Awal yaitu sejak terpisahnya lempeng Hindia-Australia dari lempeng Antartika. Pada jaman tersebut lempeng Hindia bergerak ke utara mendekati lempeng Eurasia (Sclater and Fisher, 1974; Johnson et al., 1976). Anggapan umum yang banyak diterima, menyatakan bahwa pertumbukan antara lempeng samudera Hindia dengan lempeng tepian benua Eurasia terjadi pada jaman Kapur Akhir Tersier Awal (73-55 jt) dengan lajur tunjaman berbentuk melengkung. Di Sumatra dan Kalimantan arah lajur tunjaman membentuk sudut tertentu/miring terhadap gaya utama (oblique subduction), sedangkan di Jawa berarah tegak lurus terhadap gaya utama (normal subduction); Gambar II.1. Kecepatan penunjaman lempeng samudera Hindia terhadap lempeng benua Eurasia sekitar $5-10 \mathrm{~cm} /$ tahun 


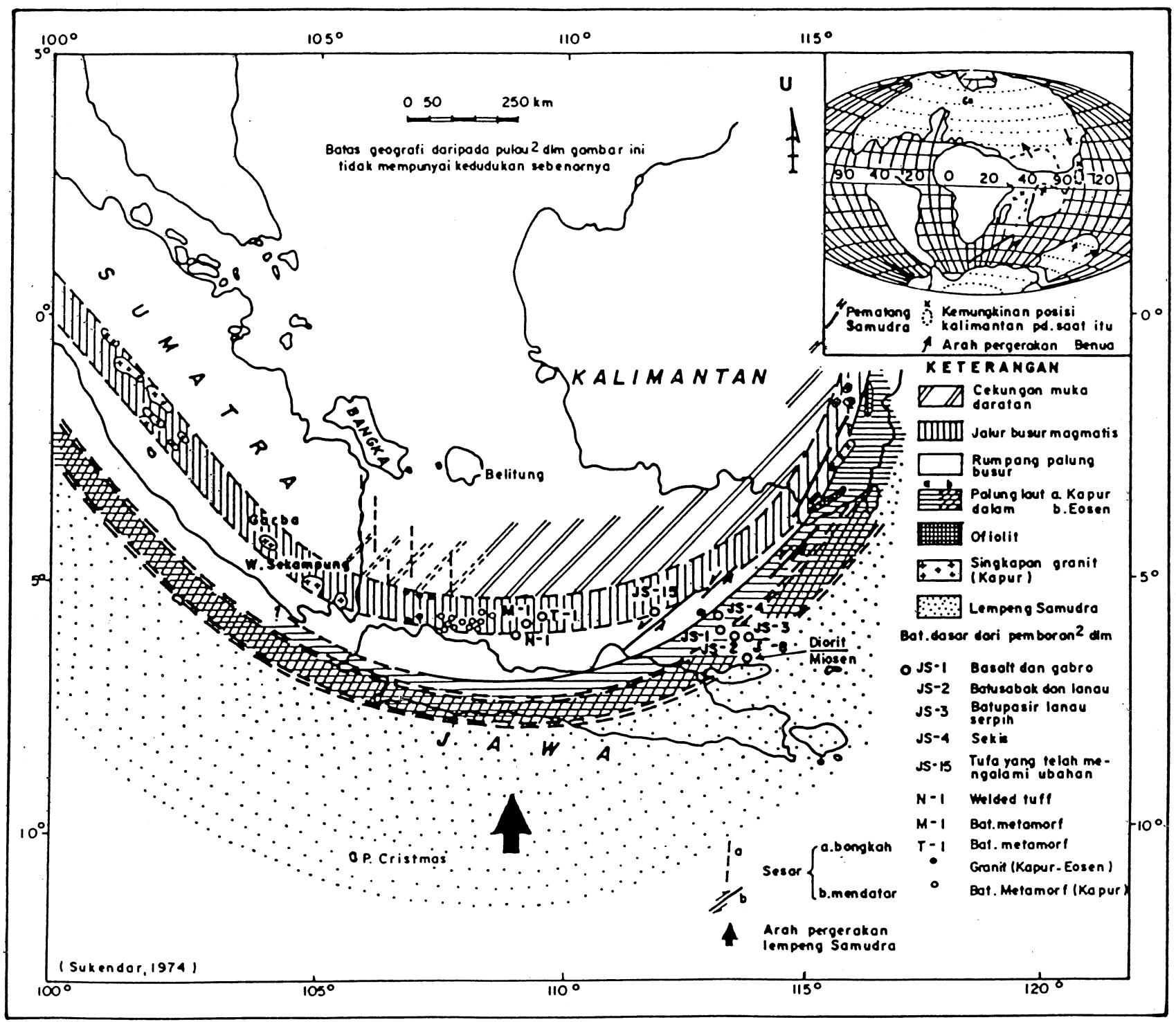

Gambar II.1. Perkembangan busur kepulauan di Indonesia bagian barat pada jaman Kapur Atas-Eosen (Sukendar, 1974). 
(Hamilton, in prep.). Selama proses penunjaman, terjadi aktifitas volkanomagmatik yang memperlihatkan kisaran umur Kapur Akhir - Tersier Awal. Penyebaran batuan volkano-magmatik tersebut sebagian terlihat di Laut Jawa yang merupakan bagian busur volkano-magmatik (Hamilton, 1979); Gambar II.2. Konsekuensi secara petrologis, akan ditunjukkan oleh kehadiran batuan volkanik yang bersifat primitif (mantle origin). Bersamaan dengan berjalannya proses penunjaman, terbentuk pula satuan batuan komplek akresi (accretionary complex) yang menghasilkan satuan batuan bancuh yang merupakan kumpulan batuan asal kerak samudera dan kerak benua. Munculnya kumpulan batuan kerak samudera sangat erat kaitannya dengan pembentukan lemping-lemping sesar sungkup (thrust-slabs). Pada saat penunjaman, mungkin tidak hanya kerak samudera saja yang menunjam, tetapi juga gunung-gunung api bawah laut (sea-mounts). Sebagai penjelasan dapat dilihat pada Gambar II.3. (Davies, 1984). Berdasarkan penyebarannya, batuan komplek akresi di Pulau Jawa tersingkap di daerah Ciletuh, Jawa Barat, Luh Ulo dan Bayat (Peg. Jiwo) di Jawa Tengah. Sedangkan di Sumatra dijumpai di daerah Gumai-Garba (de Coster, 1975) dan di Kalimantan Tenggara tersebar di daerah pegunungan Meratus - Bobaris. Pada jaman Eosen Awal sampai Oligosen Awal kecepatan penunjaman lempeng samudera Hindia terhadap lempeng tepian benua Eurasia berkurang menjadi sekitar $2,16 \mathrm{~cm} /$ tahun. Sebagai akibatnya terjadi gaya relaksi (extension) pada satuan tektonik seperti pada daerah cekungan belakang busur (back arc basin), cekungan muka busur (fore arc basin) dan komplek akresi yang disertai gerak-gerak vertikal (penurunan dan pengangkatan). Gejala ini sangat mungkin diikuti oleh aktifitas magmatik mencakup penerobosan maupun keluarnya magma di permukaan (ekstrusifa) yang bersifat toleitik maupun alkali. Pada jaman tersebut sebagian dari komplek akresi mengalami pengangkatan. Fase ini merupakan fase sedimentasi yang terjadi pada cekungan muka busur, cekungan kolam (pond) serta cekungan belakang busur. Sumber sedimentasi terutama berasal dari paparan dan busur magmatik pada cekungan belakang busur, dan percampuran dari material yang berasal dari busur 


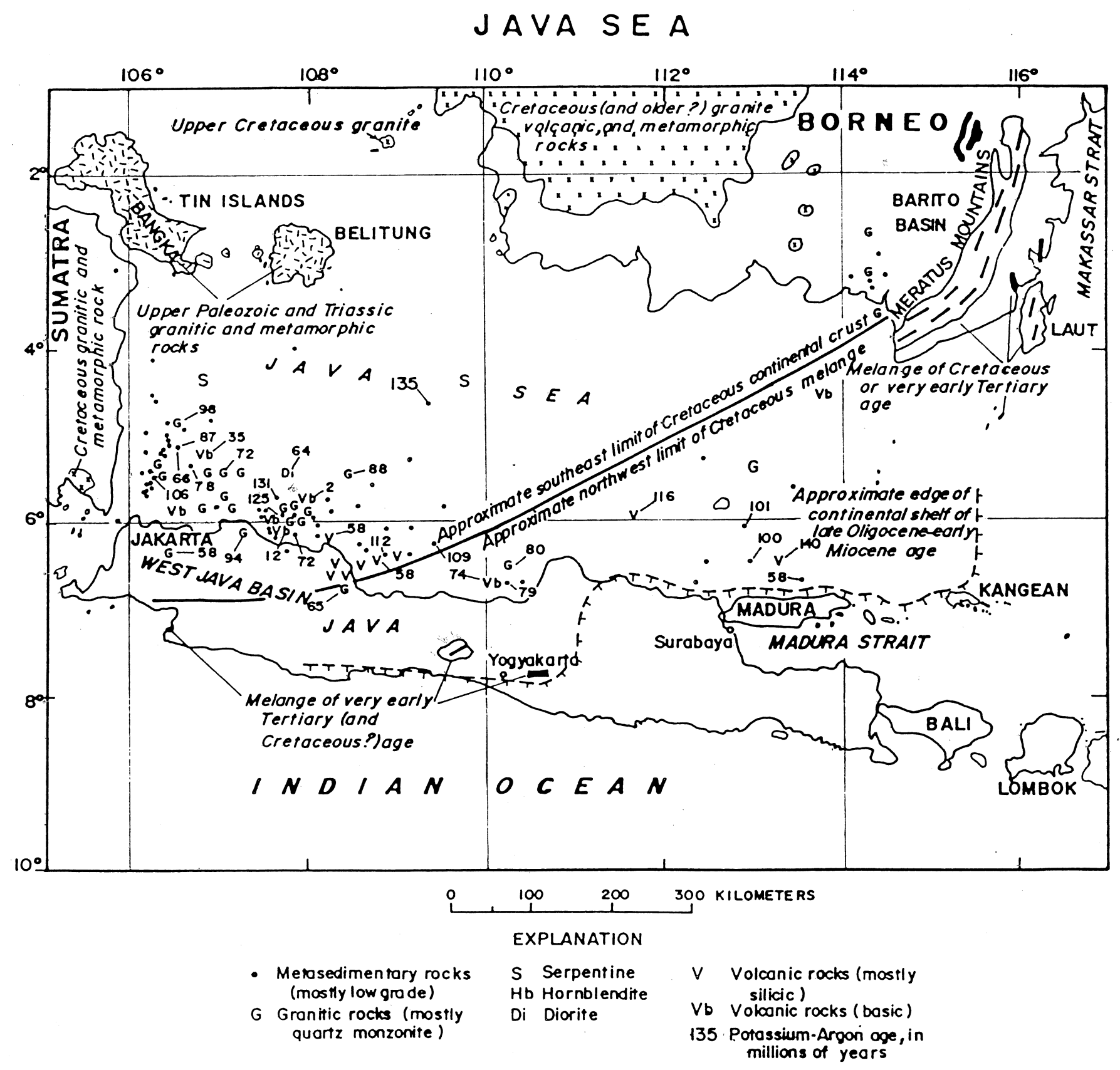

Gambar II.2. Data jenis dan umur conto batuan dasar yang diperoleh dari sumur-sumur minyak di baratlaut Jawa, Laut Jawa dan Cekungan Barito (dikutip dari Hamilton, 1979). 


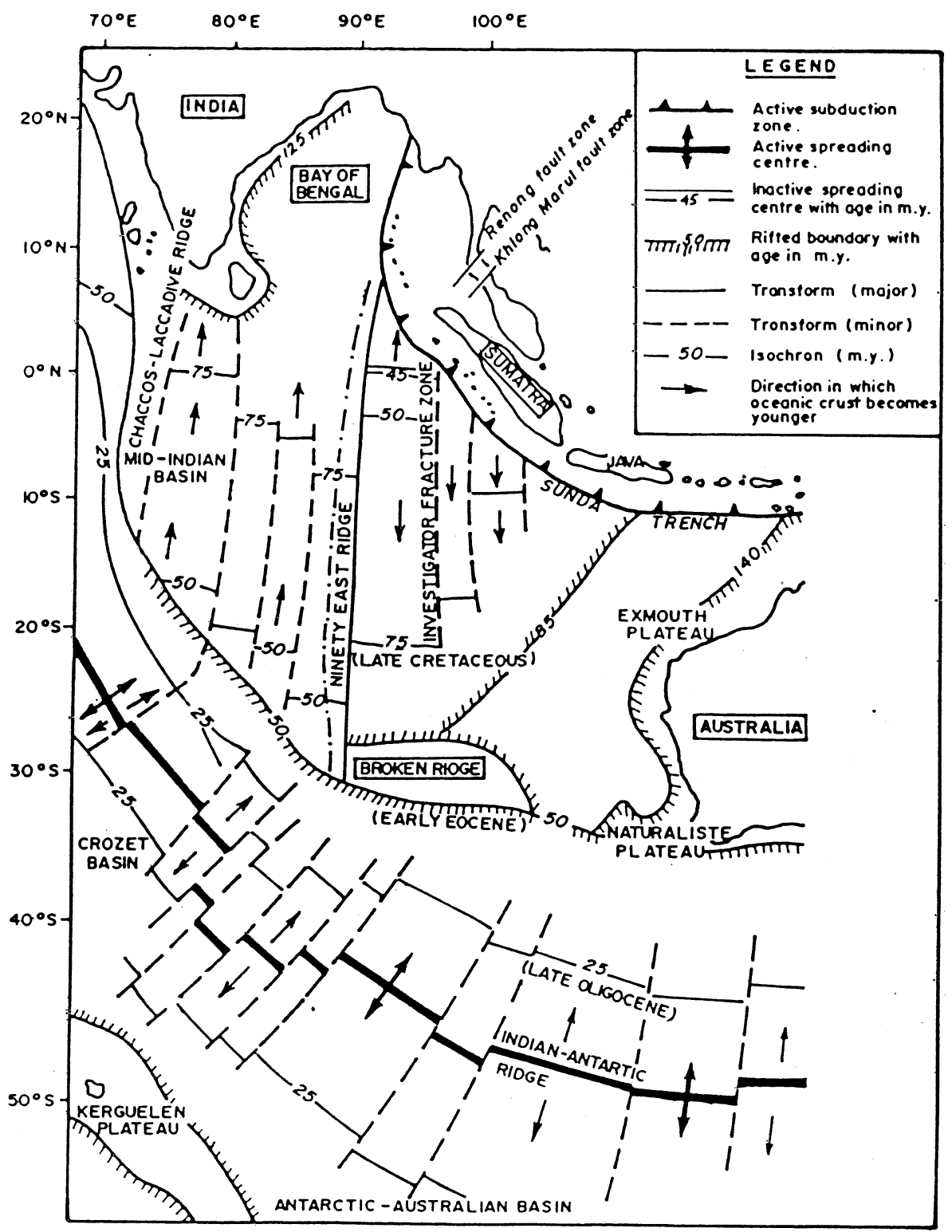

Gambar II.3. Pergerakan-pergerakan lempeng Hindia-Australia pada jaman Tersier (dikutip dari Davies, 1984). 
magmatis dengan sedimen komplek akresi pada cekungan muka busur. Sedangkan cekungan kolam umumnya menerima bahan yang merupakan hasil erosi komplek yang telah terangkat dan sebagian sedimen asal laut dalam (terutama pada cekungan kolam bagian yang lebih dalam).

\subsection{Geologi daerah Luh Ulo}

Daerah Luh Ulo - Jawa Tengah yang meliputi daerah seluas lebih kurang 30 $x 10 \mathrm{~km}^{2}$, merupakan sálah satu dari tiga daerah lainnya di P. Jawa yaitu, Ciletuh di Jawa Barat dan Peg. Jiwo di Jawa Tengah, dimana dijumpai komplek melange yang berumur Pra Tersier. Himpunan batuan yang tersingkap di daerah tersebut ditafsirkan akibat penunjaman lempeng samudera Hindia ke bawah lempeng benua Eurasia selama jaman Kapur Atas sampai Paleosen (Sukendar, 1974).

\subsubsection{Stratigrafi daerah Luh Ulo}

Daerah Luh Ulo merupakan sebagian kecil dari suatu rangkaian pegunungan yang diberi nama Pegunungan Serayu Selatan. Pegunungan ini, yang secara fisiografi oleh Pannekoek (1944) dimasukkan ke dalam lajur tengah (central zone) dari penggolongan fisiografi P. Jawa, membentuk suatu pemisah antara daerah aliran K. Serayu di utara dan daerah aliran sungai-sungai yang bermuara di Samudera Hindia. Beberapa tulisan tentang geologi dan tektonik daerah ini telah dibuat antara lain oleh Harloff (1933), Tjia (1966), Sukendar (1974), Ketner et al.(1976), Hamilton (1979), dan Sartono dkk.(1987). Dari penulis-penulis tersebut di atas (kecuali Ketner et al. dan Hamilton) telah dibuat urut-urutan stratigrafi daerah Luh Ulo yang dapat dilihat pada Gambar II.4.

\subsubsection{Stratigrafi batuan Pratersier}

Komplek Melange Luh Ulo (Sukendar, 1974) merupakan satuan batuan berumur Pratersier di daerah Luh Ulo. Penulis-penulis sebelumnya seperti Harloff (1933), dikutip dari Emmy (1972) dan Tjia (1966) seperti terlihat pada Gambar II.4., merinci adanya satuan batuan berumur Pratersier terdiri dari berbagai satuan mencakup batuan metamorfosis, batuan sedimen, dan batuan beku (lava bantal 


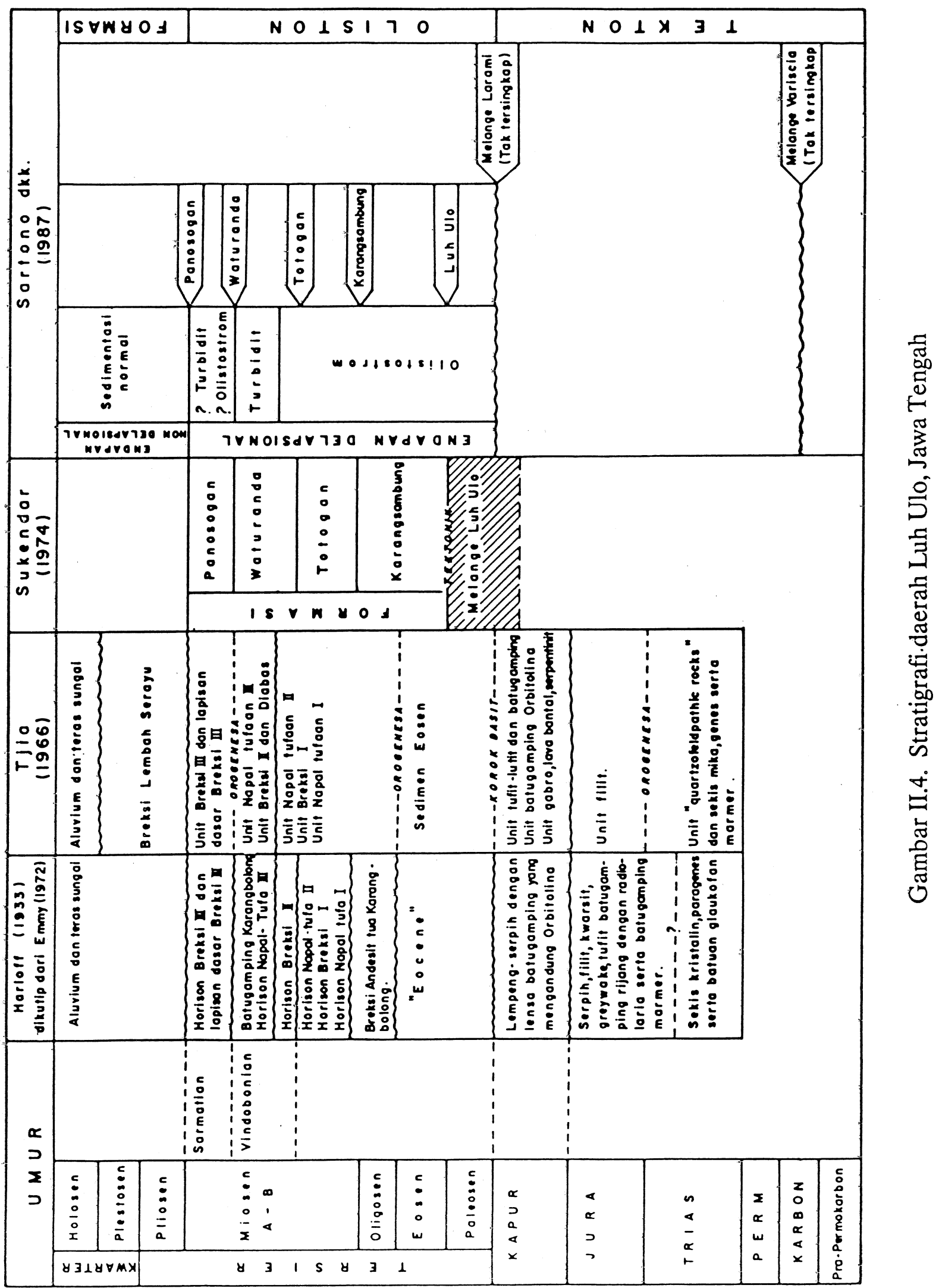


dan gabro). Lebih lanjut dikemukakan oleh kedua penulis tersebut bahwa satuansatuan batuan umumnya telah terdeformasi akibat sesar-sesar yang terjadi setelah batuan-batuan tersebut terbentuk. Sedangkan Sukendar (1974) dengan pola pemikiran berdasarkan teori tektonik lempeng, mengelompokkan semua himpunan batuan Pratersier menjadi suatu komplek batuan bancuh akibat percampuran secara tektonik, dan dinamakan sebagai Komplek Melange Luh Ulo. Satuan yang disebut terakhir ini identik dengan Olistostrom Luh Ulo menurut Sartono dkk. (1987), yang beranggapan bahwa komplek tersebut merupakan batuan bancuh sedimenter (Sartono, 1987). Perlu dijelaskan bahwa beberapa conto batuan yang mewakili masadasar / matriks maupun fragmen batupasir dari Komplek Melange Luh Ulo, Formasi Karangsambung serta Formasi Totogan telah dianalisis secara mikroskopis, dan diperoleh beberapa kesimpulan sebagai berikut - matriks dari komplek melange pada umumnya adalah batulempung terrekristalisasi, bahkan kadang-kadang adalah batusabak. Batulempung terrekristalisasi terdiri dari serisit atau mika berserabut lainnya (ilit / hidromuskovit, pirofilit), sedikit klorit dan kuarsa sekunder. Kehadiran barik-barik karbonat dan klorit juga merupakan karakteristik dari batulempung ini. Laminasi batuan dibentuk oleh orientasi dari serisit/mika berserabut, yang kadang-kadang berselingan dengan agregat kuarsa halus. Perselingan antara material mikaan dan agregat kuarsa halus makin jelas teramati pada batusabak. Di dalam batulempung ataupun batusabak seringkali dijumpai fragmen-fragmen berukuran pasir, terdiri dari kuarsit dan juga batuan lempungan yang juga telah mengalami rekristalisasi menghasilkan kuarsa dan kadang-kadang epidot. Batupasir yang mewakili fragmen dari komplek melange terdiri dari batupasir jenis wake yang mana butirannya terutama terdiri dari kuarsa, fragmen tufa, rijang, klorit dan mineral lainnya tertanam di dalam masadasar lempungan yang telah mengalami rekristalisasi menjadi mika berserabut. Umumnya batupasir ini dicirikan oleh gejala secondary outgrowth terutama pada butiran kuarsa (Lampiran Foto 3b). 
- Matriks dari Formasi Karangsambung dan Formasi Totogan agak berbeda apabila dibandingkan dengan matriks dari Komplek Melange Luh Ulo. Matriks kedua formasi ini berupa batulempung berlaminasi / menyerpih, dibentuk oleh serabut / masa lempungan yang kadang-kadang bercampur dengan karbonat (lampiran Foto 4b \& 5b). Sebagai butiran pencampur (berukuran lanau) adalah kuarsa berbentuk menyudut tanggung, felspar, mineral opak dan lainnya. Cangkang-cangkang fosil juga ditemukan di dalam batulempung ini. Conto dari keratan / fragmen batupasir yang terdapat di dalam matriks Formasi Karangsambung dicirikan oleh banyaknya butiran kuarsa dan felspar (dominan plagioklas), pecahan karbonat dan cangkangcangkang fosil foraminifera. Sedangkan fragmen batupasir Formasi Totogan ditandai oleh banyaknya fragmen batuan beku basaltik dengan masadasar karbonat (Lampiran Foto 4a \& 5a). Suatu hal yang karakteristik untuk dibedakan dengan batupasir dari satuan melange adalah tidak adanya gejala rekristalisasi baik dalam batulempung (masadasar) maupun batupasir yang mewakili fragmen Formasi Karangsambung dan Totogan. Persamaan dari conto batuan yang mewakili kedua formasi ini adalah kehadiran dari cangkang-cangkang fosil yang sangat langka dijumpai pada satuan melange, hal lain adalah banyaknya karbonat sebagai pencampur pada masadasar / semen ataupun berupa butiran di dalam batupasir Formasi Karangsambung dan juga Formasi Totogan.

Berdasarkan kepada ciri-ciri lapangan yang dikemukakan oleh Sukendar (1974), dan juga pengamatan penulis (pada waktu melakukan pekerjaan tesis S-1, 1972 dan tesis S-3 ini), dan diperkuat oleh hasil analisis mikroskopis tersebut maka dapat disimpulkan bahwa :

- Himpunan batuan (baik matriks maupun fragmen) di dalam Komplek Melange Luh Ulo umumnya telah terdeformasi dan terrekristalisasi. Dicirikan oleh adanya himpunan mineral sekunder serisit, ilit, klorit, dan kuarsa sekunder baik berupa barik-barik maupun tersebar di dalam 
masadasar batuan. Dengan demikian komplek melange ini merupakan endapan bancuh tektonik. Sedangkan Formasi Karangsambung dan Formasi Totogan mewakili endapan bancuh sedimenter, dicirikan oleh tidak adanya gejala rekristalisasi baik di dalam batulempung sebagai matriks maupun batupasir sebagai fragmen yang terkepung di dalamnya.

- Kalau dikaitkan dengan model endapan prisma akrasi dari Karig (1976) maka dapat disimpulkan bahwa Komplek Melange Luh Ulo merupakan bagian terbawah dicirikan oleh perlipatan yang kuat, terdiri dari endapan sedimen laut dalam berselingan dengan breksi dengan fragmen hasil guguran komplek melange yang mengalami penyesaran naik. Sedangkan Formasi Karangsambung dan Formasi Totogan di bagian tengah mewakili sedimen olistostrom, dicirikan oleh perlipatan yang tidak intensif di bagian bawah. Dengan demikian gejala deformasi tidak begitu intensif, sedimentasi terjadi karena lengseran akibat berat jenis saja. Kedua formasi tersebut mempunyai komposisi fragmen yang berbeda, yang mana Formasi Karangsambung didominasi oleh fragmen-fragmen batuan asal rombakan dari melange yang berasal dari daratan, sedangkan Formasi Totogan lebih banyak dibentuk oleh guguran melange yang terdiri dari material samudera (lihat Gambar II.5.). Urut-urutan stratigrafi daerah Luh Ulo setelah dimodifikasi dapat dilihat pada Gambar II.6.

Umur Komplek Melange Luh Ulo adalah Kapur Bawah hingga Paleosen, didasarkan kepada beberapa hal sebagai berikut (dikutip dari Sukendar, 1974) :

1. Adanya fosil genus Rotalipora BROTZEN yang menunjukkan umur Kapur Bawah pada batugamping merah yang bersisipan dengan rijang. Kedua batuan tersebut terbentuk bersama-sama atau di atas basalt (lava bantal).

2. Diketemukannya sisa-sisa foraminifera plangton yang diperkirakan adalah Praeglobotruncana aff delrioensis yang menunjukkan umur Cenomanian (Kapur Tengah atau Kapur Bawah bagian atas) pada batugamping terrekristalisasi berupa lensa di dalam sekis dan metagreywake. 


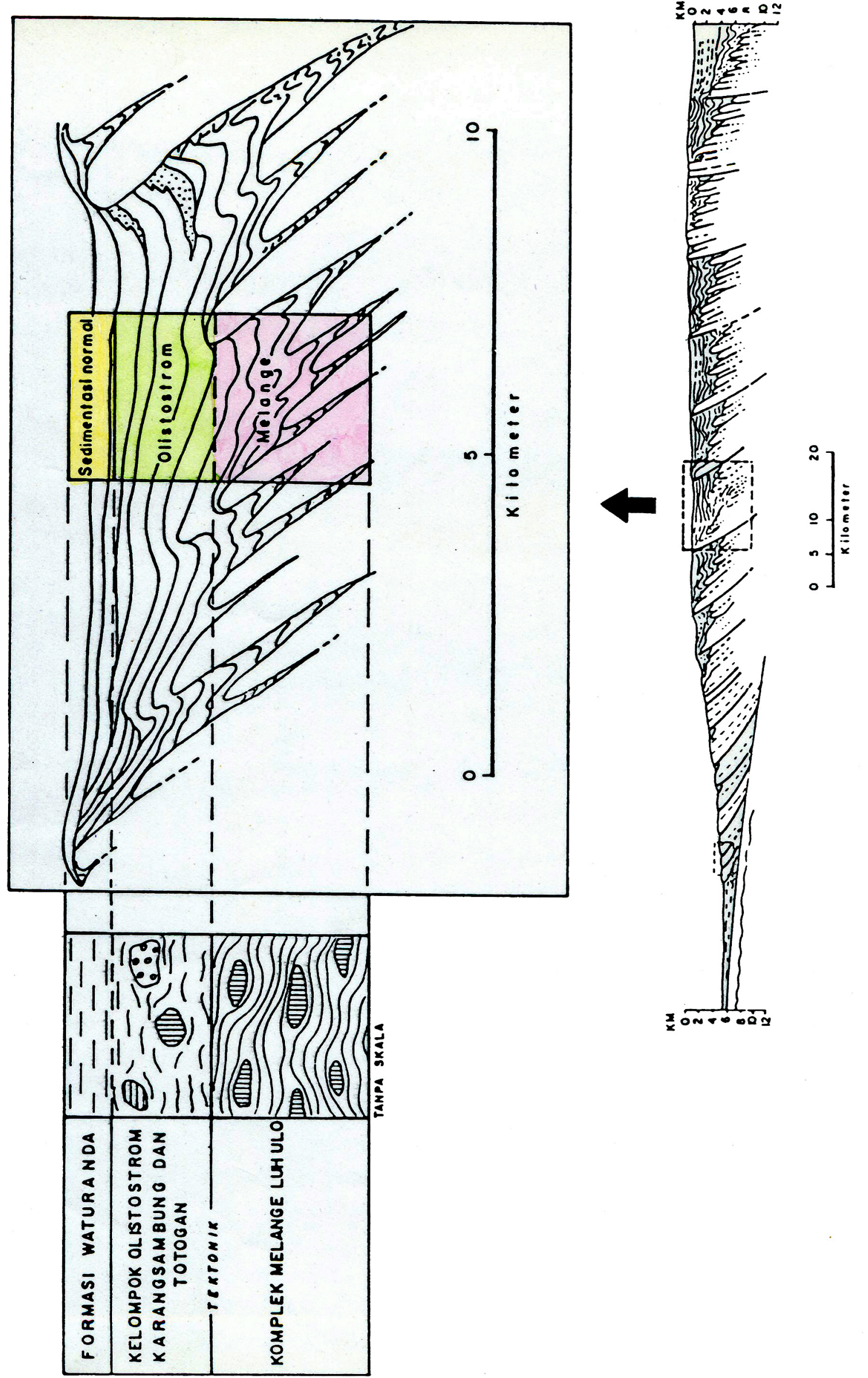

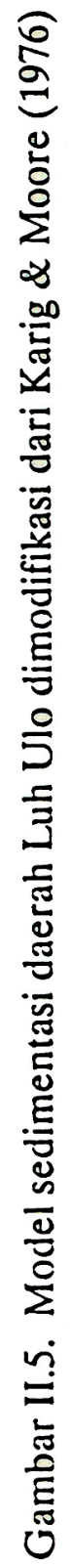




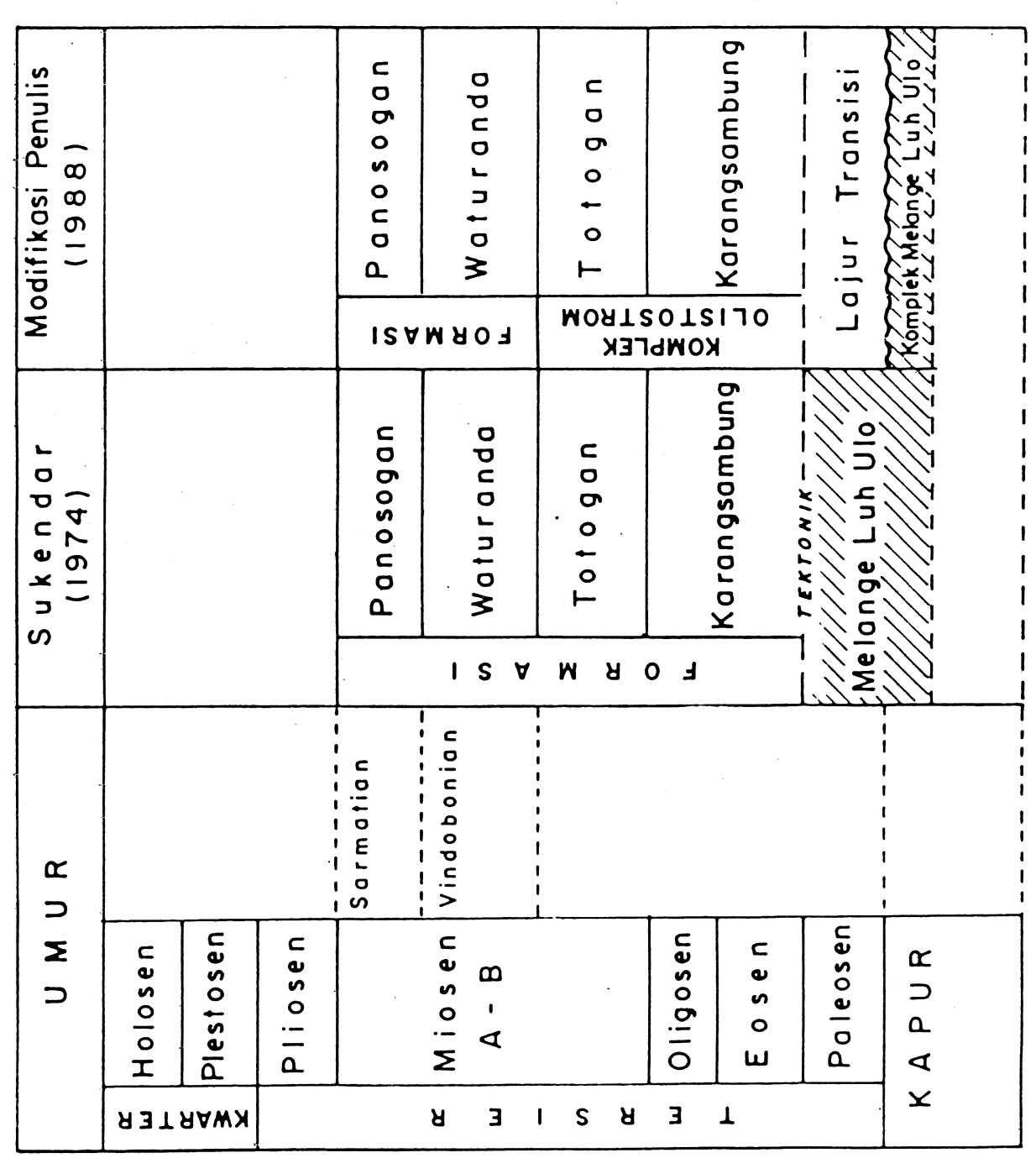

章 
3. Umur batulempung serpihan berwarna hitam yang mengalami pengirisan kuat (pervasively sheared) yang dianggap sebagai masadasar/matriks dari endapan melange adalah Kapur Atas (Campanian -Maastrichtian) ditunjukkan oleh kehadiran fosil-fosil Globotruncana stuarti_stuartiformis DALBIEZ, Heterohelix globulosa EHRENBERG, Heterohelix pulchra BROTZEN, Rugoglobigerina rugosa PLUMMER, Bolivinoides cf decoratus CUSHMAN, Stensionia cf exculpa RENZ. Selanjutnya diketemukan pula fosil-fosil Globorotalia angulata WHITE, Globorotalia triloculinoides PLUMMER di dalam lempung serpihan yang mengalami deformasi kuat yang menunjukkan umur Paleosen. Disamping fosil-fosil Globorotalia gracilis BOLII, Globorotalia aequa CUSHMAN \& RENZ dan Globigerina linaperta yang juga mempunyai kisaran umur Paleosen dan Eosen Bawah.

Selain fosil-fosil tersebut di atas, diketemukan pula fosil-fosil Globorotalia angulata WHITE, Globorotalia triloculinoides PLUMMER di dalam lempung serpihan yang terdeformasi kuat. Kedua fosil tersebut menunjukkan umur Paleosen.

Selain daripada ketiga hal tersebut di atas, dapat pula ditambahkan bahwa pentarikhan umur dari salah satu bongkah atau boudin porfir kuarsa di dalam melange, menunjukkan umur 65 juta tahun atau batas antara Kapur Akhir dan Paleosen; pentarikhan umur dilakukan dengan metoda jejak belah (fission track) terhadap mineral sirkon dari batuan porfir kuarsa tersebut (dikutip dari Ketner et al., 1976). Dari penulis tersebut juga diperoleh data umur sekis mika serta filit dari komplek yang sama, berturut- turut $117 \pm 1,1$ juta tahun berdasarkan metoda $\mathrm{K}$-Ar, dan 85 juta tahun dengan metoda Rb-Sr.

Selanjutnya dalam kaitannya dengan disertasi ini juga telah dilakukan pentarikhan radiometri dengan $\mathrm{K}-\mathrm{Ar}$ terhadap sekis mika, yang menghasilkan umur 101,71 \pm 5,09 juta tahun (dikerjakan oleh Bellon, di Laboratoire de Geochimie - Universite de Bretagne Occidentale, Brest, 1987). 


\subsubsection{Stratigrafi batuan Tersier}

Satuan batuan berumur Tersier yang tersingkap di daerah ini terdiri dari Formasi Karangsambung, Formasi Totogan serta Formasi Waturanda.

Formasi Karangsambung terdiri atas lempung berwarna abu-abu sampai kehitaman yang memperlihatkan struktur bersisik (scaly clay) yang dianggap sebagai masadasar / matriks. Di dalamnya dijumpai lensa-lensa atau fragmen-fragmen batugamping numulites, konglomerat polimik, serta batupasir berlapis dengan ukuran beberapa puluh $\mathrm{cm}$ hingga beberapa puluh meter. Didasarkan kepada struktur di lapangan seperti kenampakan bersisik pada matriks lempung, bentuk fragmen-fragmennya maka Formasi Karangsambung ditafsirkan sebagai endapan olistostrom, yang mana pengendapannya adalah akibat lengseran di bawah permukaan air, dan dalam volume yang besar. Umur formasi ini adalah Eosen Tengah sampai Akhir didasarkan pada kandungan fosil-fosil foraminifera plangton Globorotalia centralis CUSHMAN \& BERMUDEZ pada lensa batugamping yang menunjukkan umur Eosen Tengah, dan adanya Globigerapsis sp yang menunjukkan umur Eosen Atas pada lempung tufaan.

Formasi Totogan mempunyai ciri-ciri litologi yang hampir serupa dengan Formasi Karangsambung yaitu terdiri dari lempung bersisik berwarna abu-abu sampai ungu kemerahan. Didasarkan kepada ciri-ciri litologinya di lapangan formasi ini dikelompokkan menjadi tiga satuan yaitu dari bawah ke atas berturut-turut satuan breksi lempung (didominasi oleh fragmen lempung), satuan lempung serpihan, dan satuan breksi terdiri dari fragmen-fragmen basalt (dominan), batugamping numulites, batupasir dan konglomerat. Seperti halnya dengan formasi sebelumnya, Formasi Totogan ditafsirkan sebagai endapan olistostrom. Penentuan umur formasi ini didasarkan kepada fauna mikro yang dijumpai dalam pada lempung breksi yang terdiri dari campuran fauna Eosen, Oligosen, dan Miosen Bawah, serta adanya fosil-fosil foraminifera berumur Oligosen di dalam lempung serpihan yang bersisipan dengan napal (Djoehanah, 1973 dikutip dari Sukendar, 1974), maka Formasi Totogan diperkirakan berumur 
Oligosen - Miosen Bawah. Secara selaras ke bagian atas, Formasi Totogan beralih ke Formasi Waturanda yang terdiri dari perselingan breksi volkanis dengan batupasir tufaan.

\subsubsection{Ofiolit Karangsambung Utara}

Himpunan batuan mafis-ultramafis di daerah Luh Ulo tersingkap disebelah utara desa Karangsambung mencakup daerah seluas lebih kurang $10 \times 3,5 \mathrm{~km}^{2}$; pola penyebaran berarah timurlaut - baratdaya serta memperlihatkan kontak tektonik dengan satuan batuan di sekitarnya di bagian utara dan selatannya (Gambar II.7.). Rekonstruksi geologi komplek ofiolit di daerah penyelidikan didasarkan pada hasil pengamatan geologi lapangan di sepanjang lintasan sungai yang berarah utara - selatan yang memotong hampir tegak lurus pola penyebaran ofiolit; lintasan tersebut antara lain mengikuti sungai-sungai Pakuruhan, Curugdawa, Medana, Lokidang, dan Parakansubah.

\subsubsection{Ciri-ciri umum di lapangan}

Hasil penyelidikan di lapangan menunjukkan bahwa komplek ofiolit daerah Karangsambung Utara terdiri dari :

1. Batuan ultramafis mencakup batuan harsburgit terserpentinkan, serpentinit, dan lersolit. Perlu dijelaskan bahwa istilah terserpentinkan digunakan untuk batuan yang telah mengalami serpentinisasi, dan mengandung serpentin antara 20\% - 50\%; sedangkan istilah serpentinit digunakan untuk batuan yang terdiri dari serpentin lebih dari $50 \%$.

2. Batuan mafis terdiri dari gabro (kumulat dan non kumulat/masif), diabas, dan lava bantal.

Himpunan batuan mafis - ultramafis tersebut pada umumnya memperlihatkan batas antar satuan berupa kontak tektonik. Gejala deformasi seperti adanya retakan-retakan yang terisi mineral sekunder (barik-barik / urat-urat) maupun yang tidak terisi, breksiasi, serta milonitisasi merupakan ciri umum yang teramati di lapangan. Bahkan tidak jarang dijumpai kenampakan adanya 


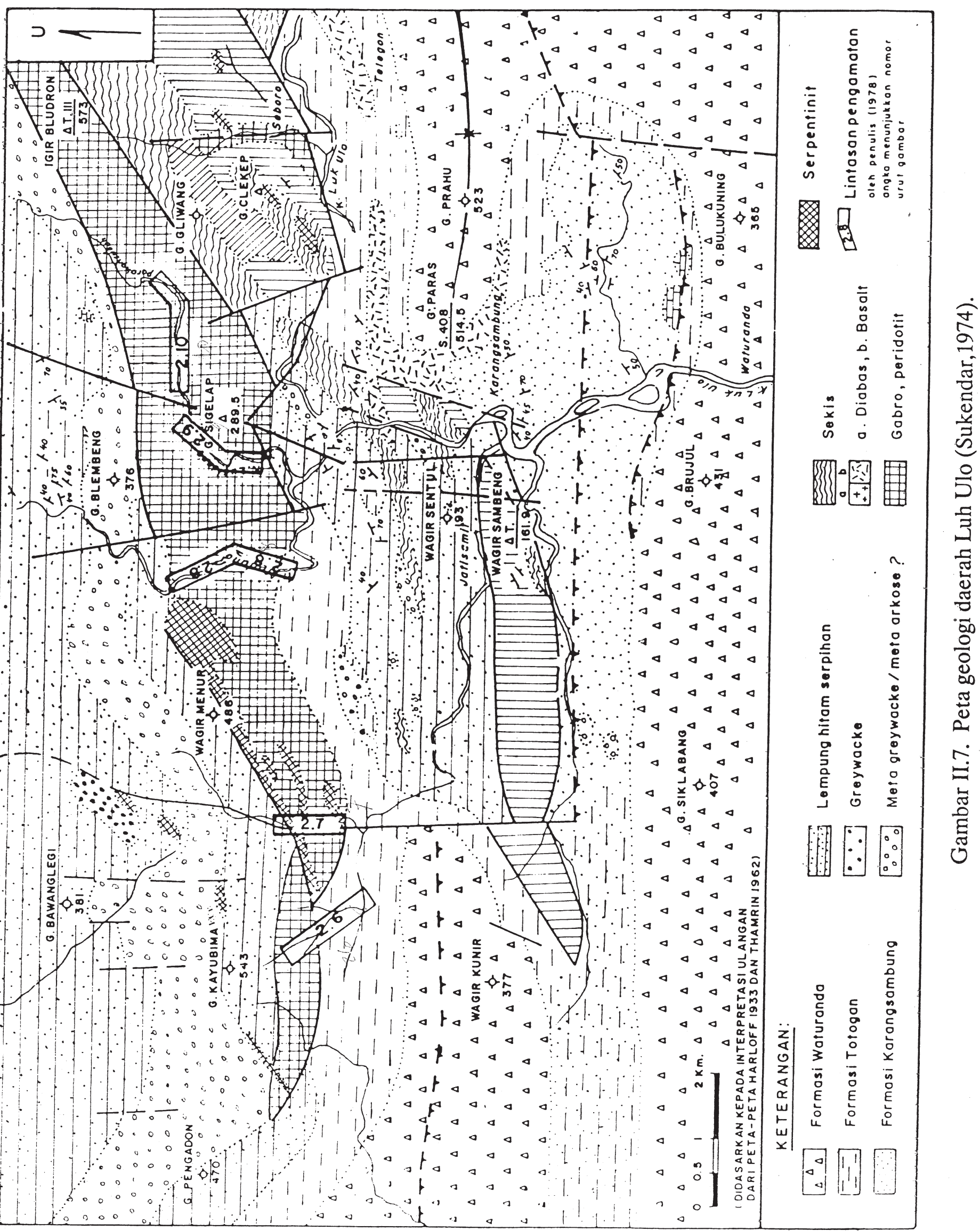


bongkah-bongkah (berukuran beberapa puluhan cm sampai beberapa puluhan meter) maupun bentuk-bentuk melensa dari batuan mafis maupun ultramafis yang seolah-olah terkungkung di dalam matriks yang tidak lain adalah batuan sejenis yang terdeformasi sangat kuat (termilonitkan dan juga terrekristalisasi). Perlu diingatkan bahwa pengelompokan satuan-satuan batuan tersebut didasarkan kepada jenis batuan yang terbanyak tersingkap pada lintasan melalui sungai-sungai dipilih.

\subsection{Batuan ultramafis}

Batuan ultramafis menempati tidak lebih dari $10 \%$ daerah ofiolit secara keseluruhan. Sebagian besar dijumpai pada bagian utara, terutama terdiri dari harsburgit terserpentinkan dan serpentinit. Lersolit hanya diketemukan di beberapa tempat saja, antara lain di lintasan sungai Curugdawa dan Parakansubah. Meskipun sebagian besar batuan ultramafis yang dijumpai di daerah penyelidikan telah terubah cukup kuat, serta telah mengalami deformasi, jejak tekstur asal dari batuan tersebut masih dapat dilihat secara mikroskopis. Di lapangan batuan ultramafis umumnya terkoyakkan cukup kuat, ditandai oleh warna hijau kehitaman -mengkilat akibat penggerusan/milonitisasi yang sangat kuat sehingga menghasilkan antara lain mineral serpentin dengan/tanpa klorit; pada beberapa tempat batuan ultramafis juga dijumpai berupa bongkah-bongkah, atau bodin (boudin) yang memperlihatkan orientasi tertentu (umumnya berarah timurlaut - baratdaya) sebagai akibat deformasi yang kuat tersebut.

\subsection{Batuan mafis}

Batuan mafis yang tergolong ke dalam ofiolit Karangsambung Utara terdiri dari gabro, diabas, dan basalt. Gabro dan diabas menempati bagian tengah dari komplek ofiolit sedangkan basalt lebih banyak dijumpai di bagian selatan. Dari pengamatan lapangan di beberapa lintasan singkapan gabro dijumpai lebih banyak di bagian barat; sebagai contoh dapat dilihat pada lintasan sungai Medana dan Lokidang. Lintasan sungai Medana (Gambar II.10) didominasi oleh gabro yang 
seringkali berasosiasi dengan diabas (Foto II.1a,b), sedangkan di sepanjang sungai Lokidang singkapan gabro yang masif baru diketemukan pertama kali pada lokasi yang lebih ke utara (lihat Gambar II.11.). Seperti halnya pada batuan ultramafis, batuan gabro yang dijumpai sebagian telah mengalami pengubahan dan deformasi (Foto II.2a); seringkali dijumpai barik-barik (veinlets) kuarsa, karbonat (berwarna putih), dan epidot (Foto II.2b.). Secara megaskopis gabro mempunyai besar butir bervariasi dari sedang sampai sangat kasar (mencapai $1 \mathrm{~cm}$; Foto II.3a,b), dan kebanyakan terdiri dari gabro masif yang banyak tersingkap di daerah penyelidikan; gabro berlapis (kumulat) hanya dijumpai pada lintasan sungai Curugdawa (di belokan cabang sungai Sirnabaya). Di bagian utara batuan gabro berlapis ini berasosiasi dengan batuan ultramafis. Makin ke selatan besar butir batuan gabro semakin halus.

Diabas dicirikan oleh tekstur ofitik yang jelas teramati pada singkapan, yang membedakan dari basalt. Kadang-kadang nampak adanya fenokris plagioklas memberikan warna bintik-bintik putih pada diabas yang agak lapuk. Batuan diabas memperlihatkan hubungan yang sangat erat dengan gabro; seringkali dijumpai bongkah-bongkah gabro di dalam singkapan diabas, maupun sebaliknya. Hal ini mungkin terjadi karena secara genesis, retas diabas terdapat pada bagian teratas dari lapisan gabro di dalam komplek ofiolit; selain daripada itu, khususnya di daerah penyelidikan, hampir semua batuan yang tercakup di dalam komplek ofiolit memperlihatkan kontak sesar, sehingga memungkinkan adanya percampuran antar masing-masing batuan (Foto II.4a,b.). Basalt merupakan anggota komplek ofiolit yang terbanyak dijumpai di bagian selatan yang ditandai oleh singkapan berwarna hitam, kadang-kadang agak kehijauan atau kemerahan dan memperlihatkan struktur bantal (Foto II.5a,b). Seperti halnya dengan batuan lainnya di dalam komplek ofiolit, basalt juga dicirikan oleh gejala deformasi yang ditunjukkan dengan adanya berbagai lajur milonitisasi (Foto II.6a) serta retakan yang umumnya telah diisi oleh karbonat atau kuarsa (berwarna putih, Foto II.6b). Basalt tersingkap lebih banyak di bagian selatan yang berbatasan dengan sedimen berumur Tersier 


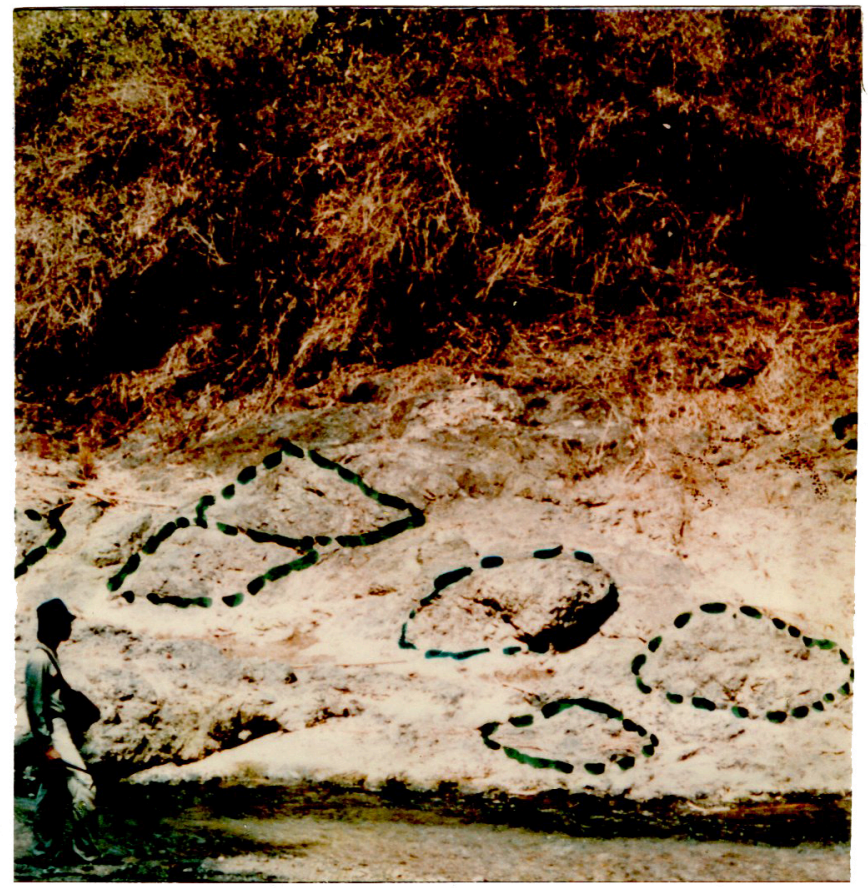

Foto II.1a. Singkapan gabro masif yang seringkali memperlihatkan adanya bongkah - bongkah diabas. Lokasi S. Medana.

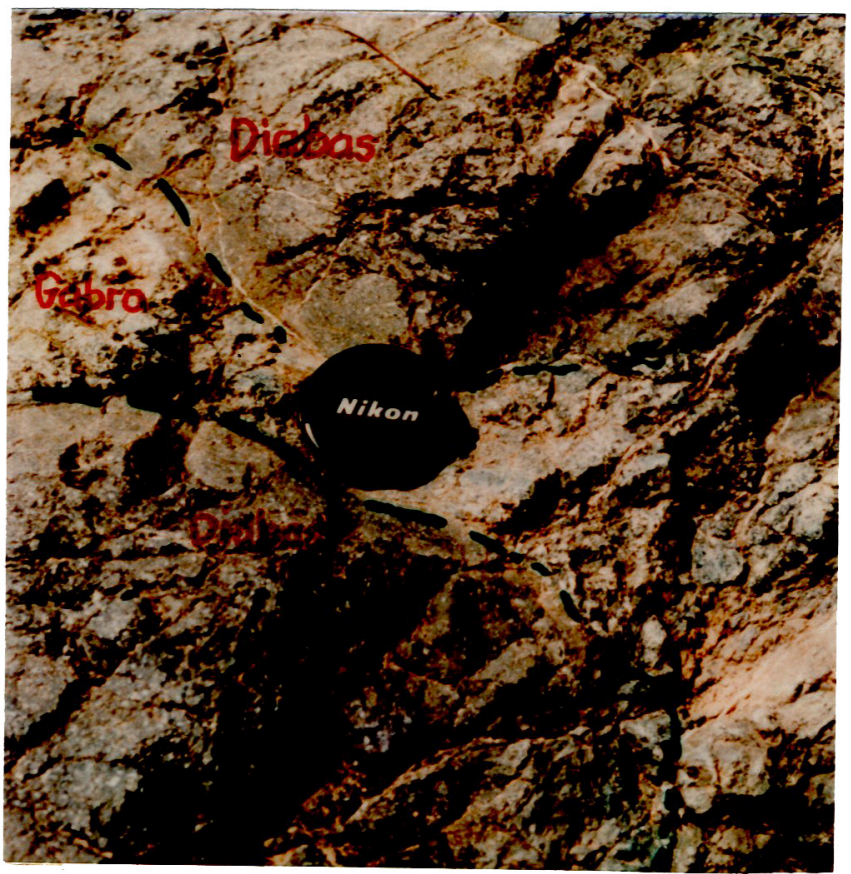

Foto II.1b. Perhatikan bintik-bintik putih fenokris plagioklas pada bongkah diabas. Lokasi S. Medana. 


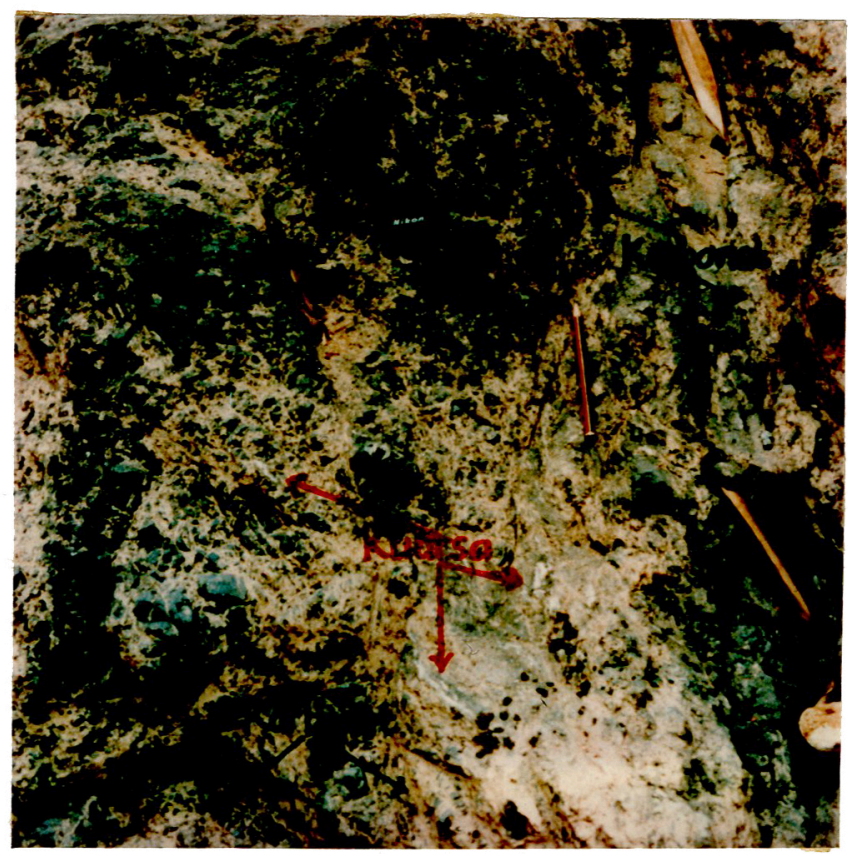

( a )

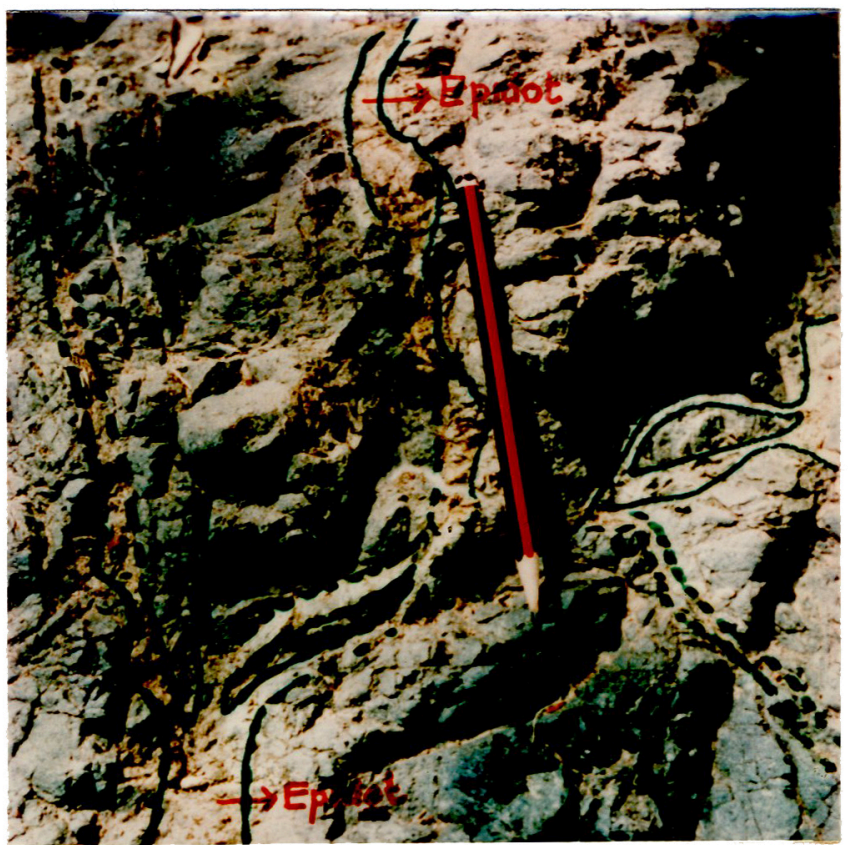

( b )

Foto II.2. Singkapan gabro yang telah terubah dan terdeformasi. Perhatikan gejala breksiasi pada kedua foto serta banyaknya barik-barik kuarsa atau karbonat (putih) pada foto II.2a, dan barik epidot (kuning pucat) pada foto II.2b. Lokasi S. Medana. 


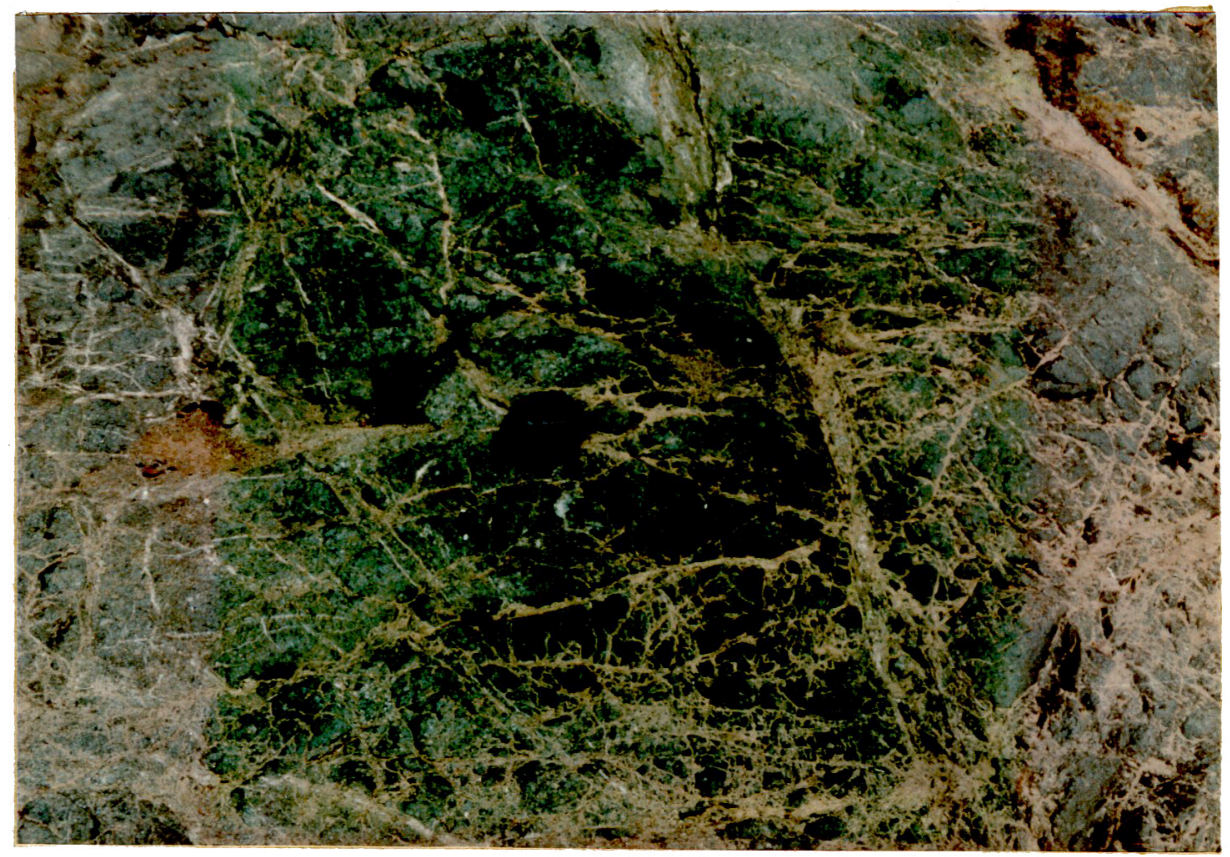

( a )

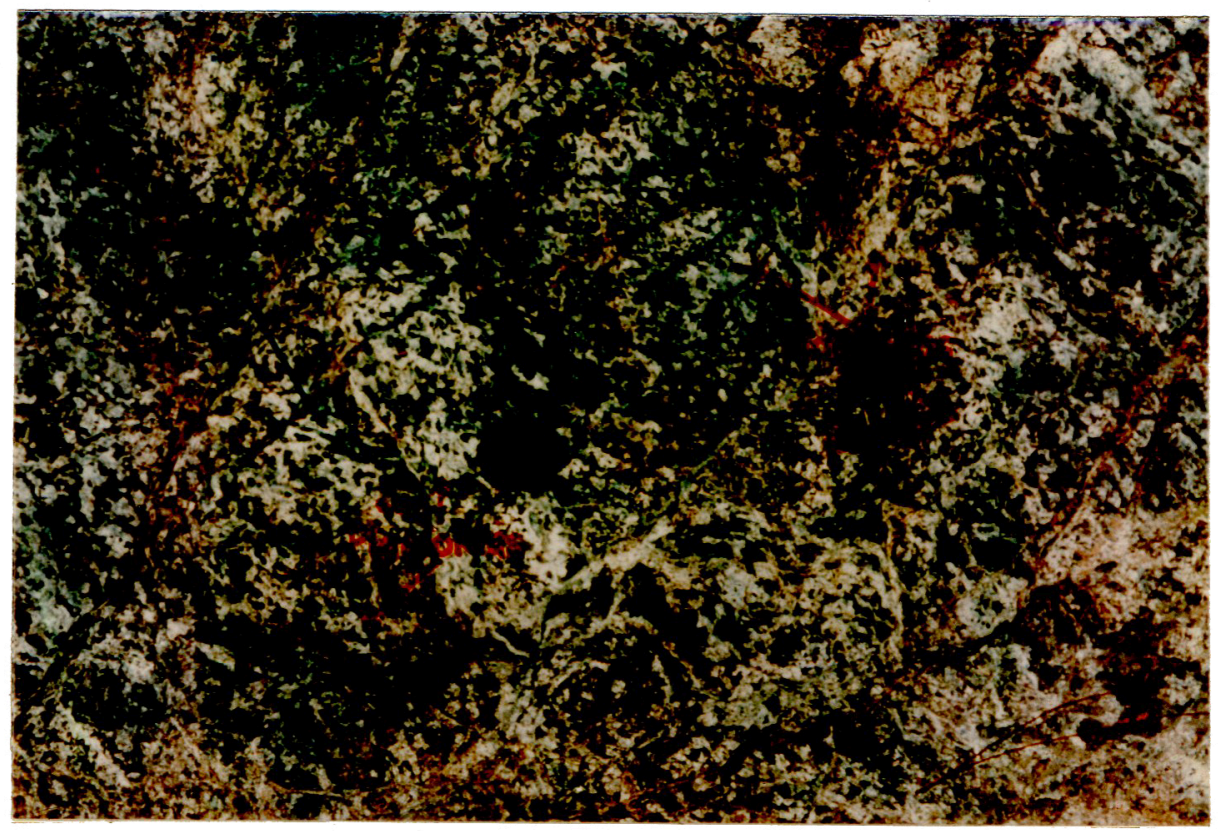

( b )

Foto II.3. "Close up" dari singkapan gabro berbutir halus (a) dan gabro berbutir kasar (b). Perhatikan bercak-bercak putih dari mineral plagioklas dan piroksen berwarna hijau (foto II.3b). Lokasi S. Medana. 


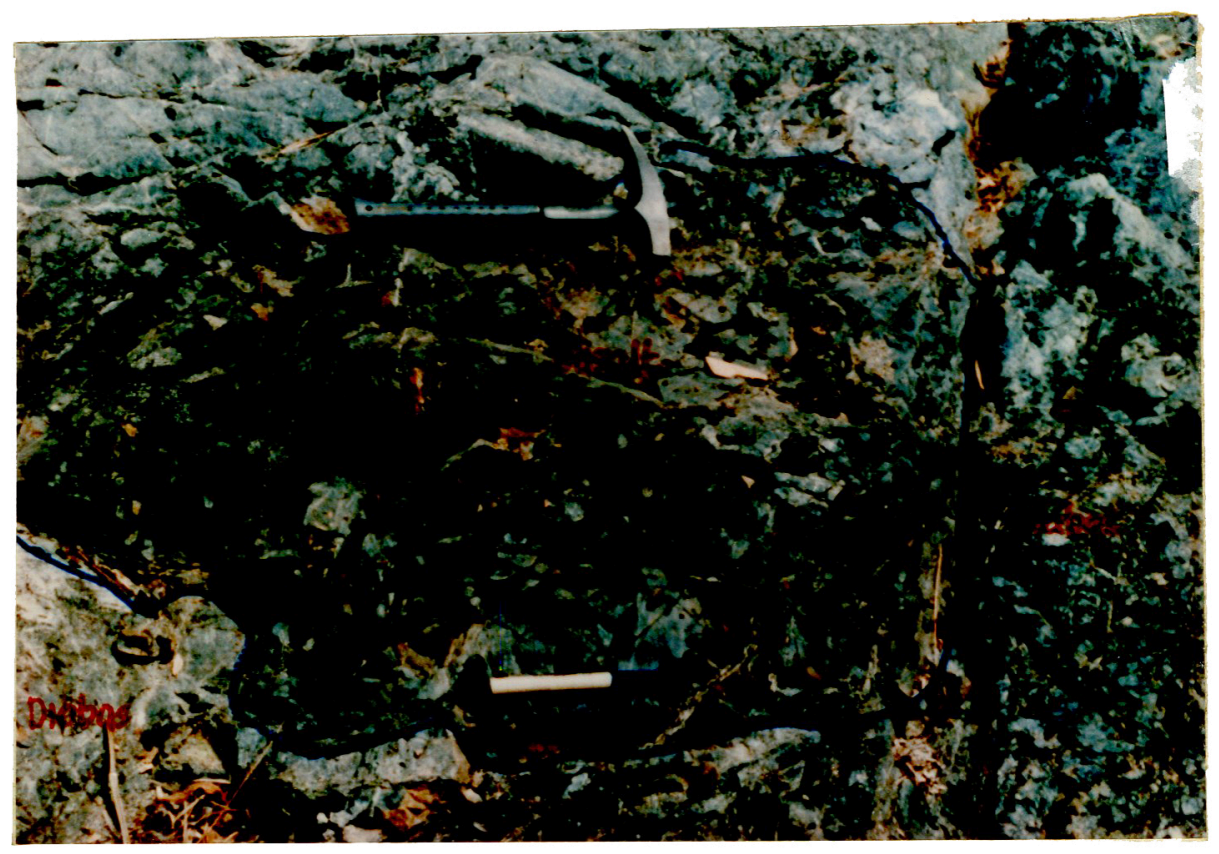

( a )

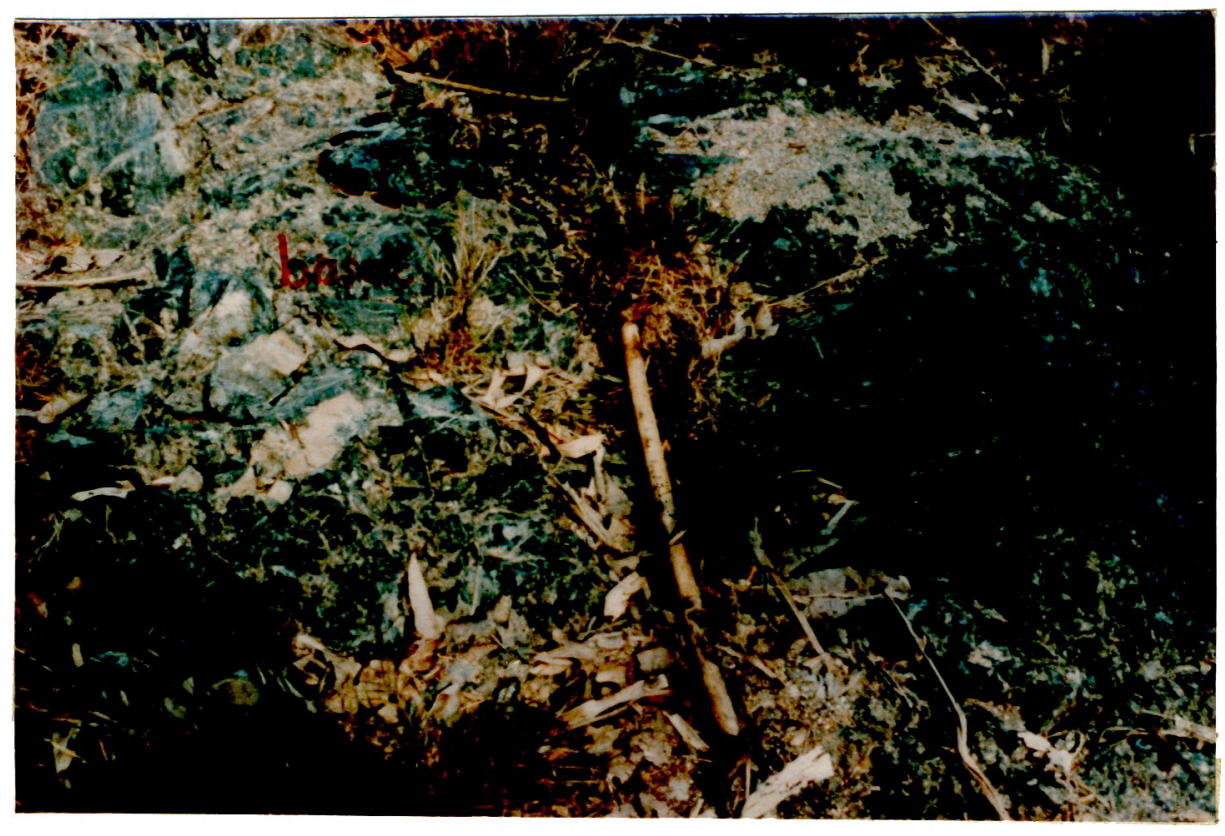

( b )

Foto II.4. Singkapan diabas yang memperlihatkan adanya bongkah atau blok basalt (a); tidak jarang diketemukan singkapan yang terdiri dari percampuran antara diabas, gabro dan basalt ( $b$ ). Lokasi S. Lokidang. 


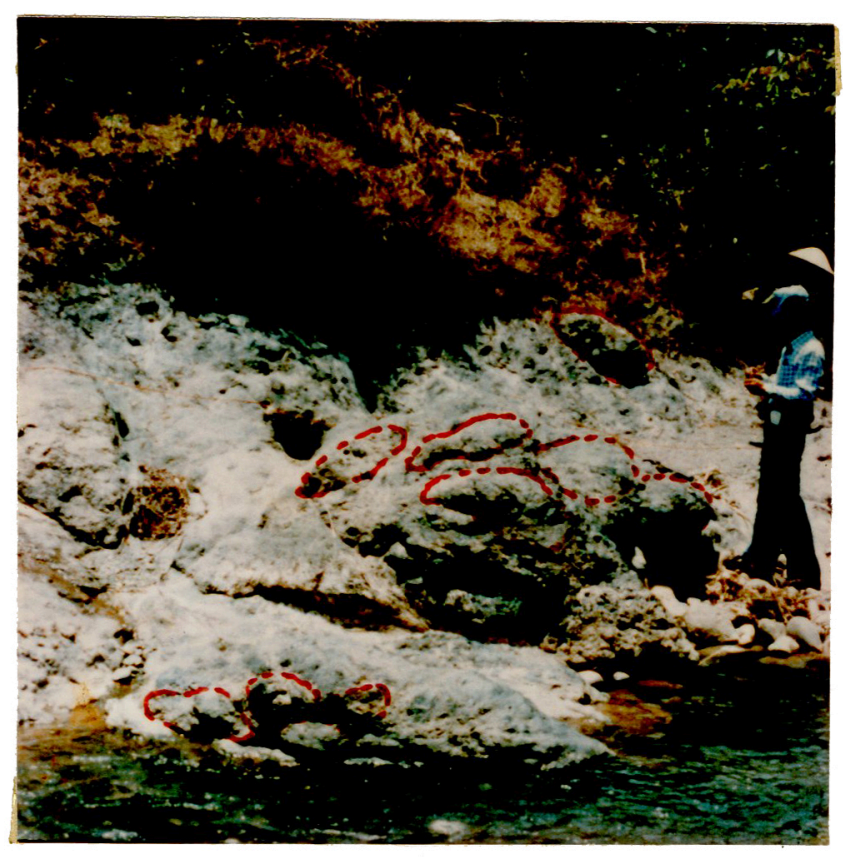

( a )

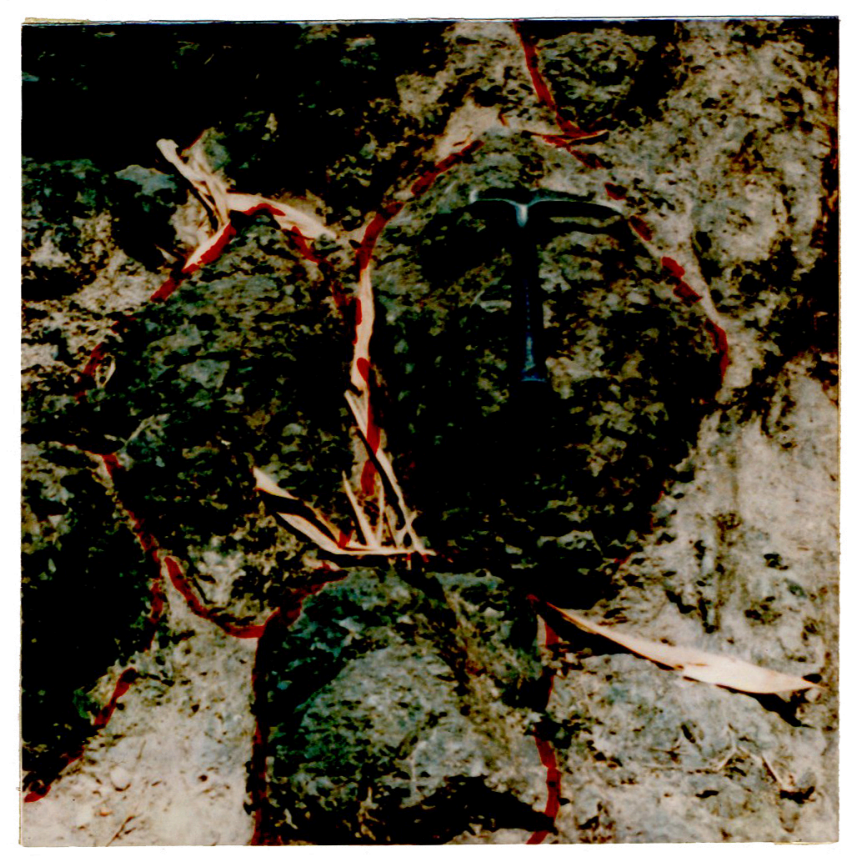

( b )

Foto II.5. Singkapan lava basalt berstruktur bantal yang sangat jelas terlihat pada foto II.5b. Lokasi S. Lokidang. 


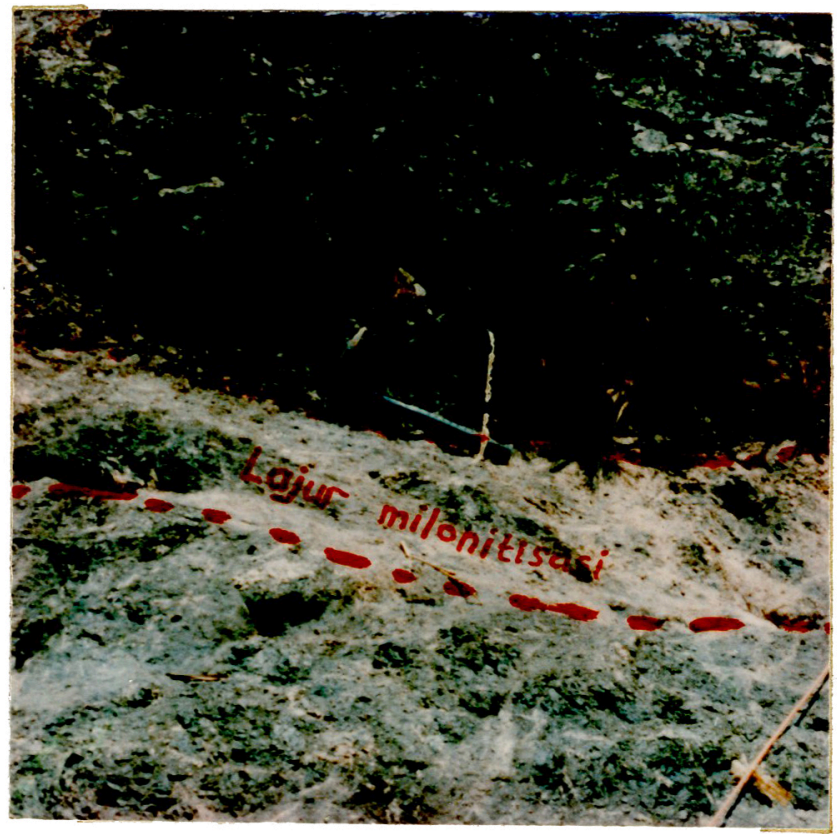

( a )

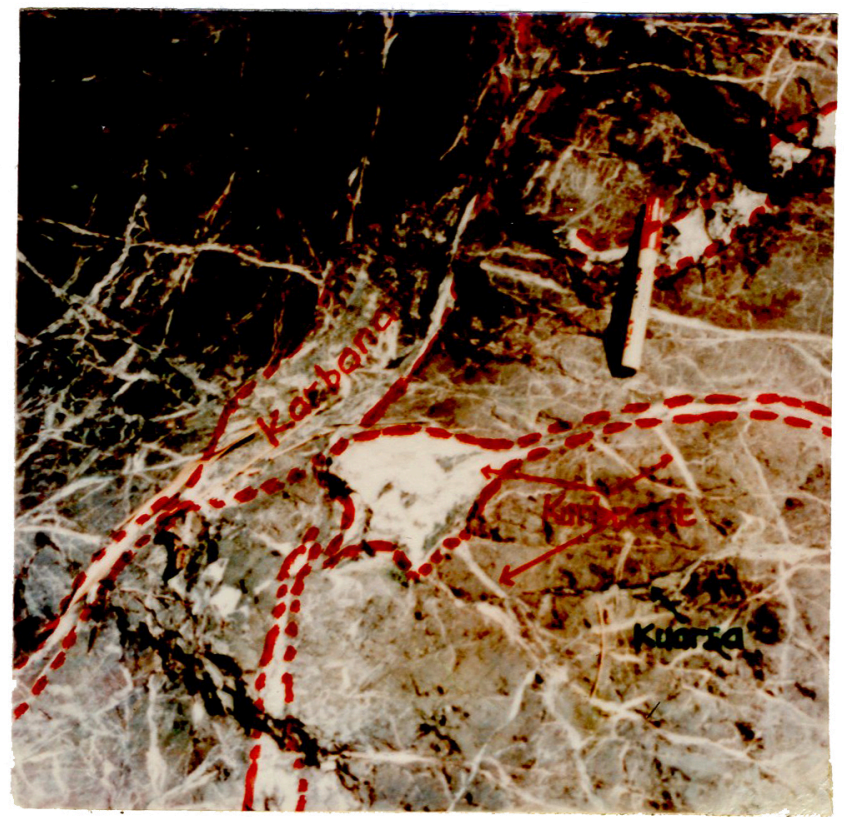

(b)

Foto II.6. Singkapan lava bantal terdeformasi yang dicirikan oleh gejala milonitisasi (a), serta barik-barik kuarsa atau karbonat berwarna putih yang saling memotong (b). Lokasi S. Lokidang. 
berupa kontak sesar. Dari hasil pengamatan di sepanjang beberapa lintasan sungai (Gambar II.8 sampai dengan Gambar II.12) telah dibuat penampang kolom untuk setiap lintasan seperti yang terlihat pada Gambar II.13a; pada Gambar II.13b. dapat juga dilihat penampang kolom ofiolit di daerah penyelidikan yang disebandingkan dengan penampang kolom ofiolit yang ideal (Penrose, 1972) dan ofiolit Pegunungan Meratus di Kalimantan Tenggara (Sikumbang, 1986). Yang disebutkan terakhir ini merupakan salah satu komplek ofiolit yang sampai saat ini dianggap mempunyai hubungan genetis di dalam tatanan tektonik regional. Selain daripada itu dapat juga disimpulkan bahwa :

1. Penyebaran masing-masing batuan dari utara ke selatan berturut-turut adalah batuan ultramafis, gabro (kumulat dan non kumulat/masif), diabas, dan basalt. Di bagian utara komplek ofiolit ini berbatasan dengan batuan metamorfosis, sedangkan di bagian selatan berbatasan dengan batuan sedimen yang termasuk ke dalam Komplek melange Luh Ulo

2. Batas antar batuan berupa kontak tektonik, yang pada umumnya berupa sesar sungkup.

3. Kadang-kadang dijumpai bongkah-bongkah batuan sedimen (batulempung, batupasir, ataupun batugamping-rijang merah, konglomerat), dan batuan metamorfosis (meta kuarsit, marmer, sekis mika, sekis amfibolit, sekis glaukofan) di dalam masing-masing batuan beku lainnya yang juga tergolong di dalam komplek ofiolit daerah penyelidikan.

4. Masing-masing batuan telah mengalami deformasi yang cukup kuat, ditandai dengan gejala-gejala milonitisasi/breksiasi, adanya struktur menyerupai bodin maupun bongkah, retakan-retakan maupun barik-barik. Demikian juga proses pengubahan juga merupakan ciri umum teramati di lapangan.

\subsubsection{Geokronologi}

Sejumlah 4 (empat) conto batuan yaitu dua batuan mafis, satu batuan metamorfosis (sekis mika), dan satu dasit telah ditentukan umurnya dengan metode pentarikhan radiometri K-Ar. Tujuan dari pentarikhan radiometri ini 


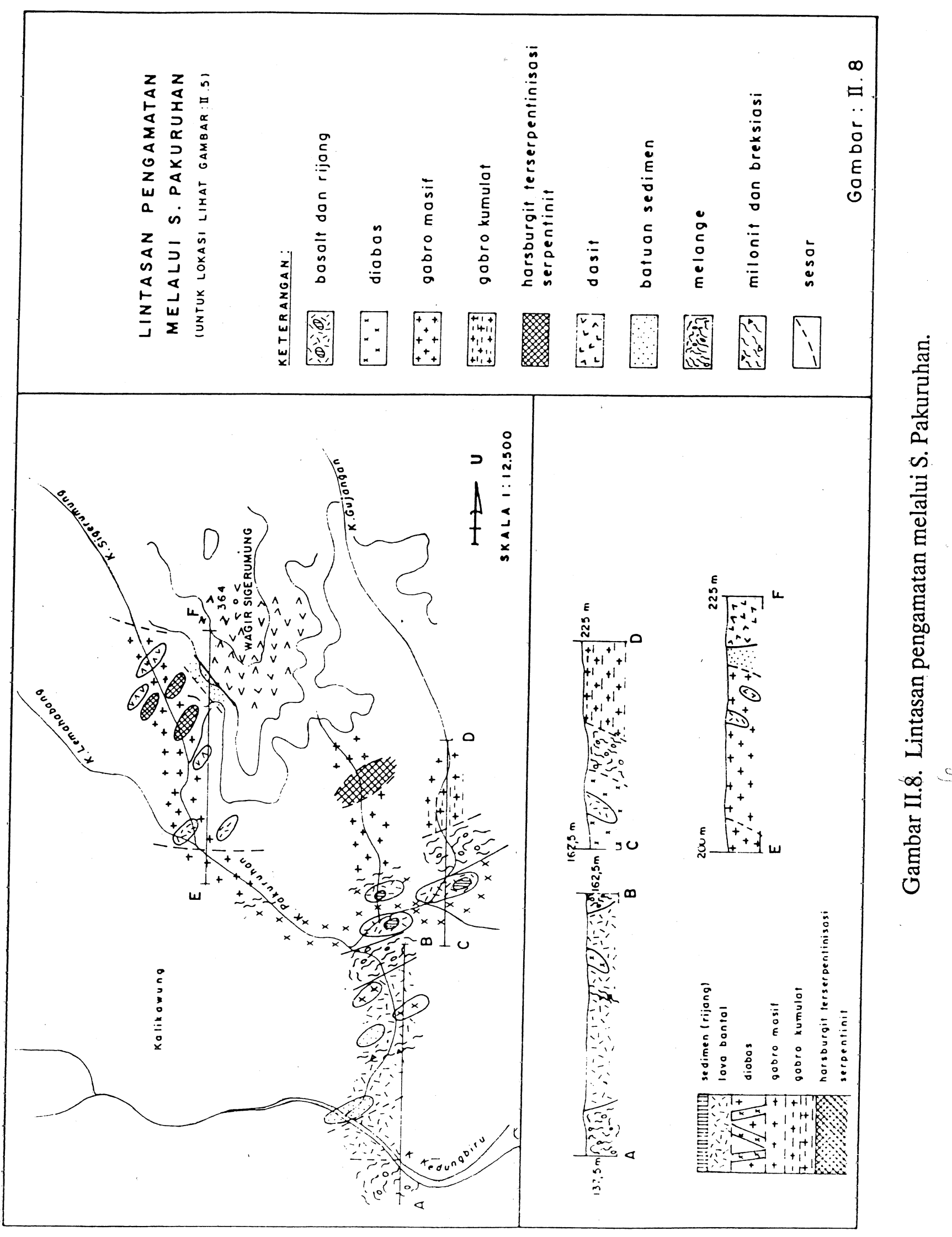




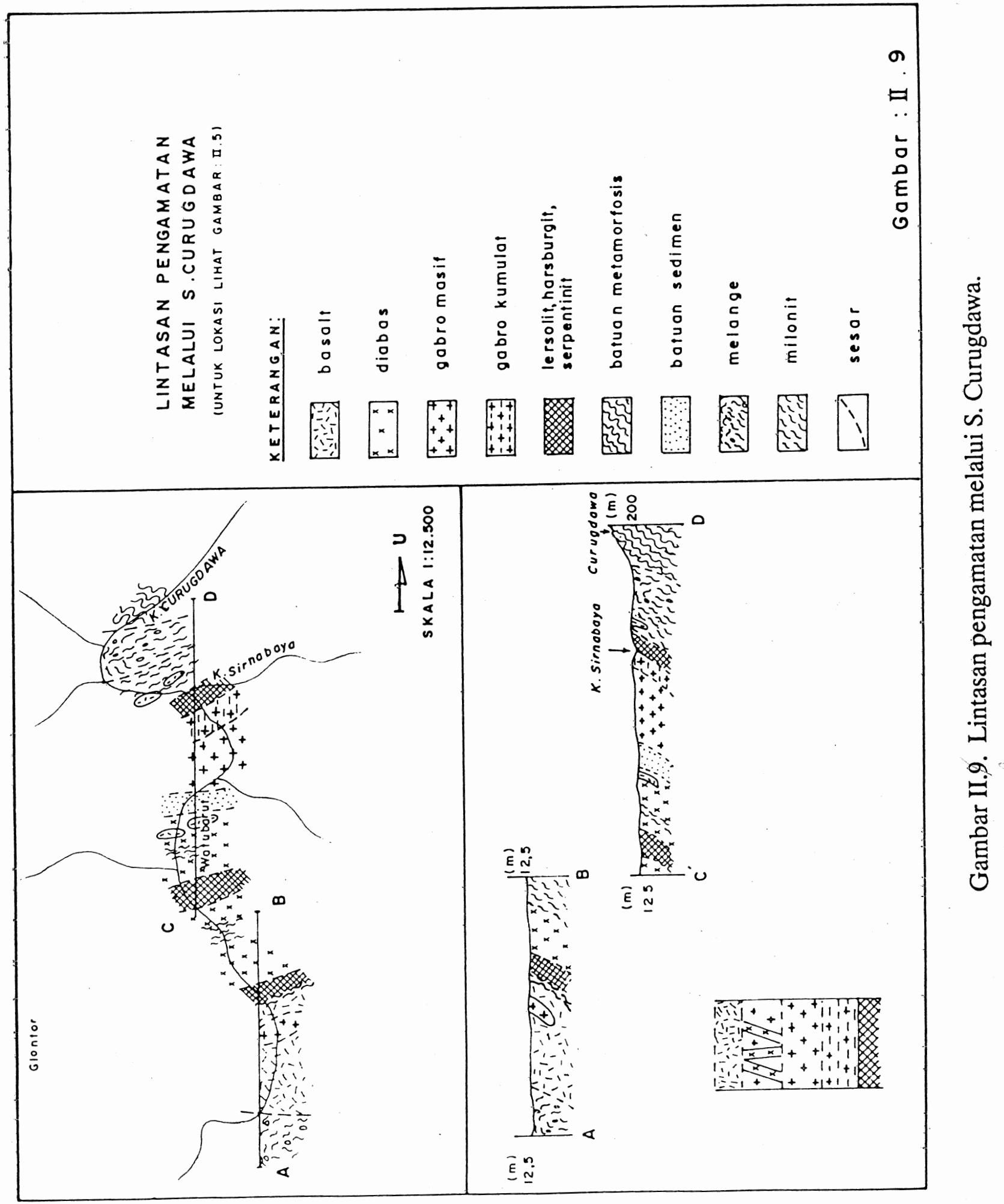




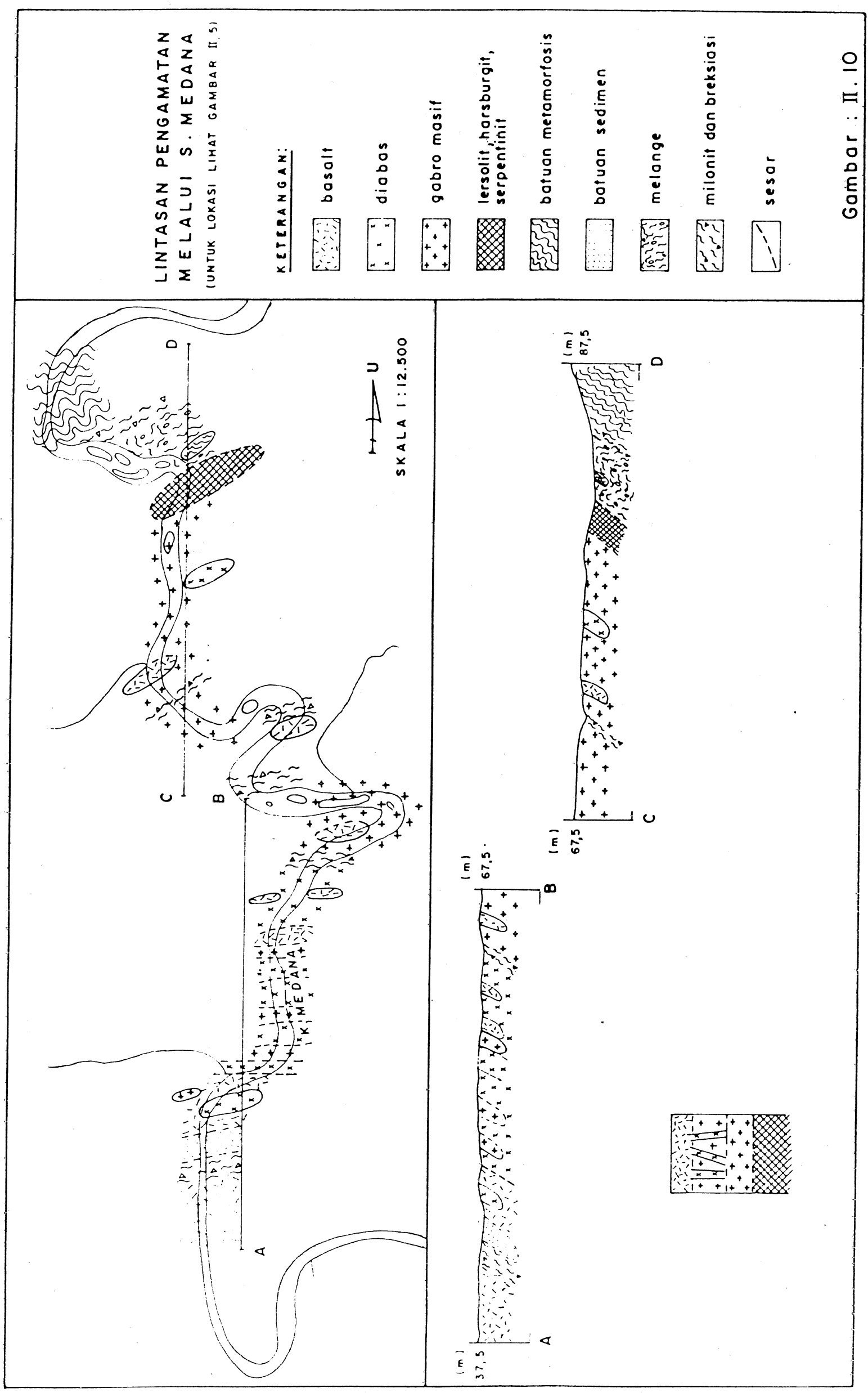

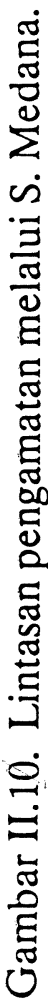




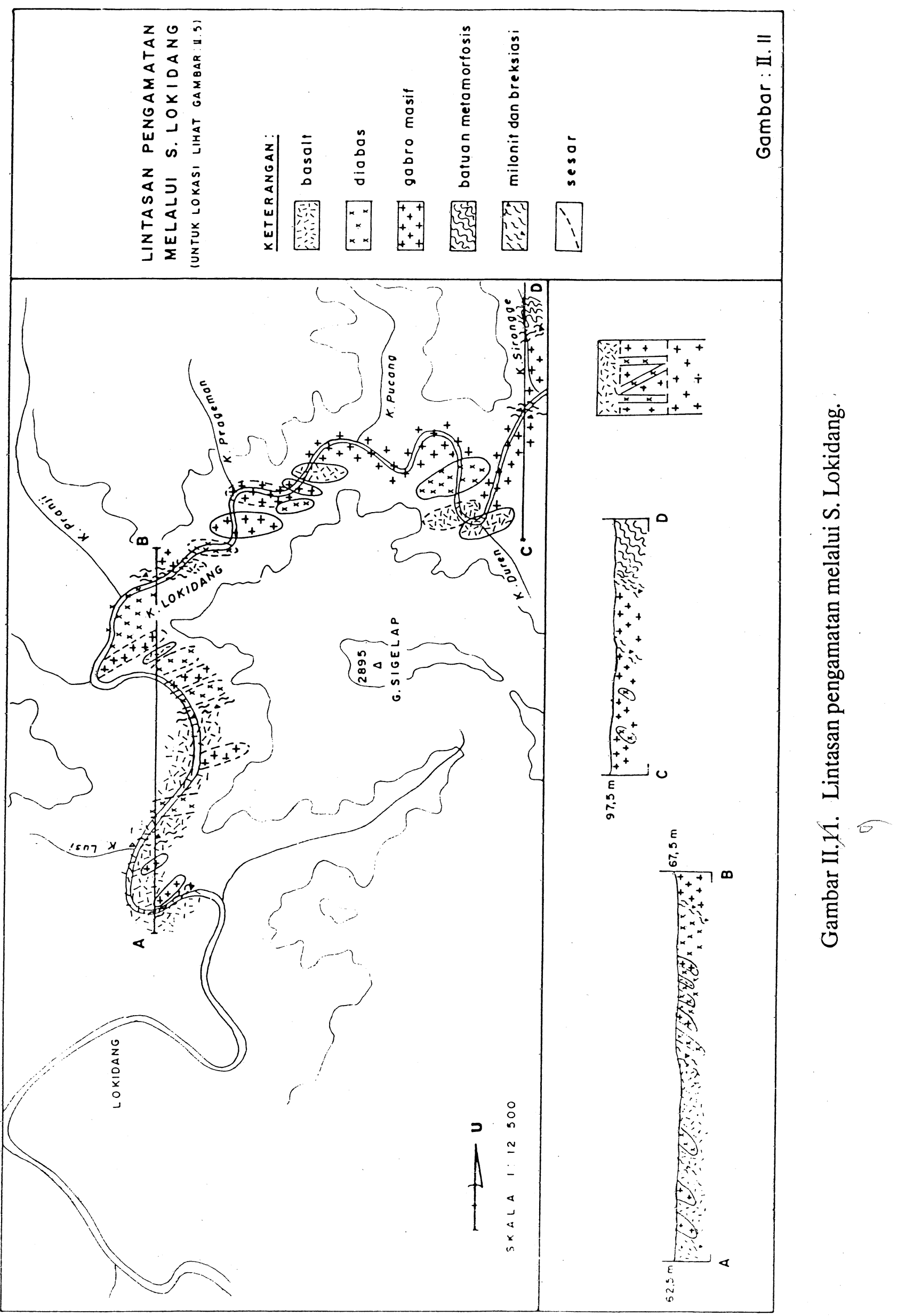




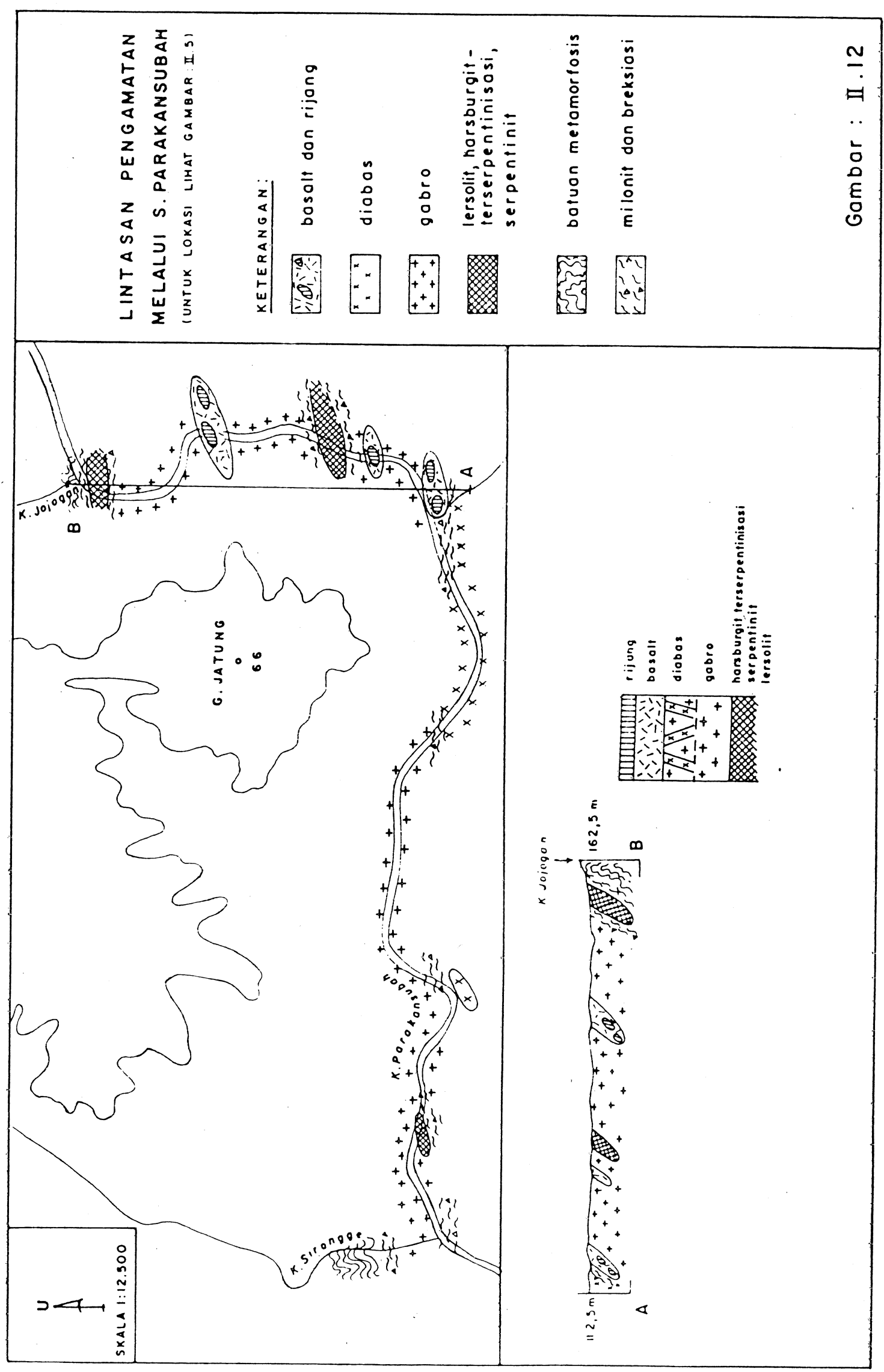

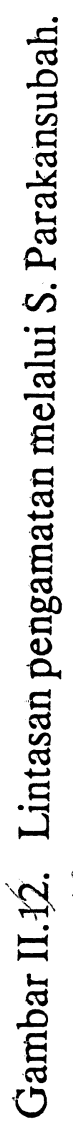




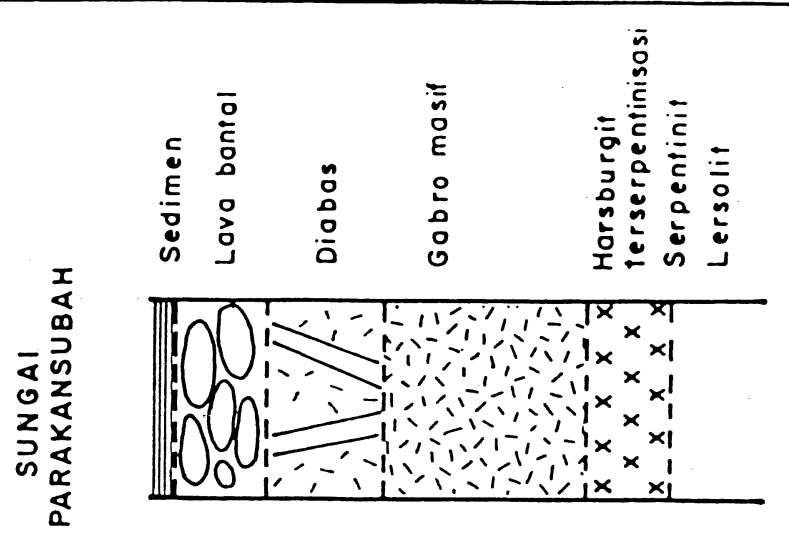

돔

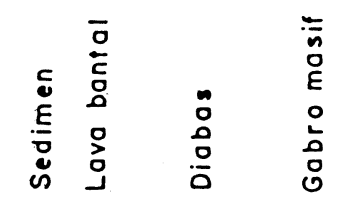

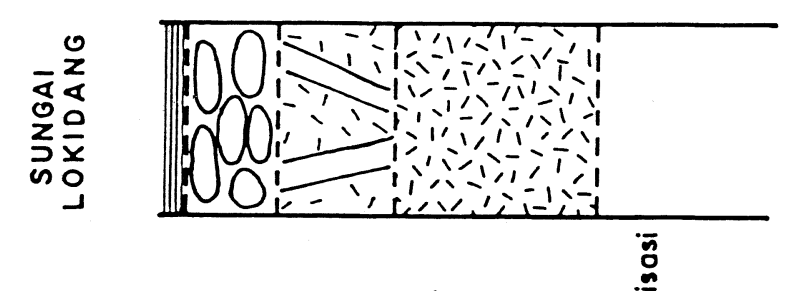

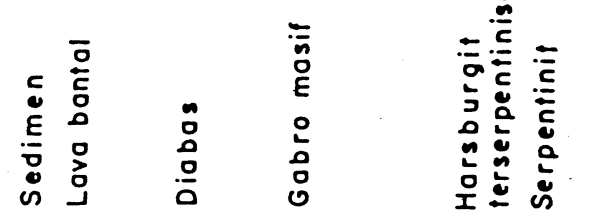
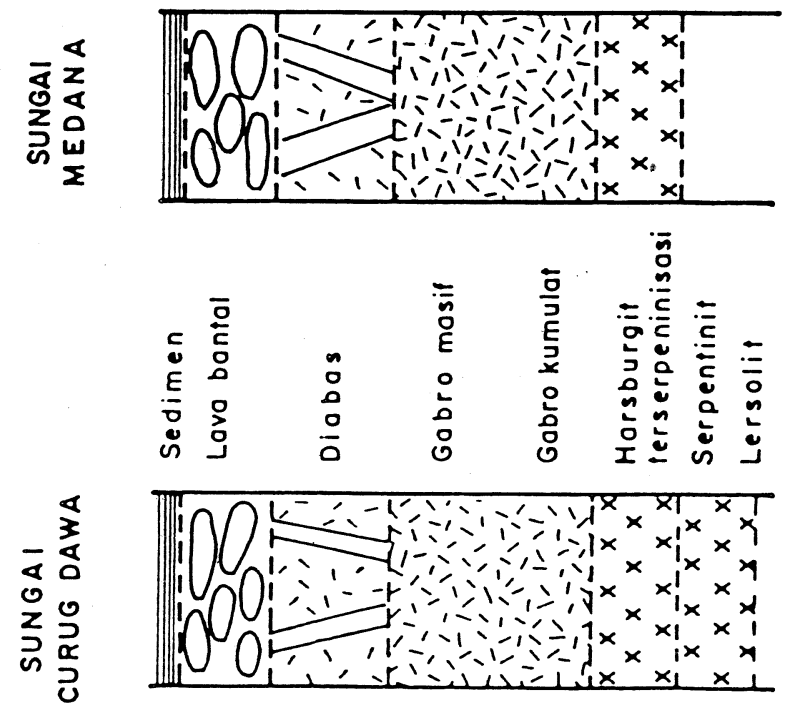

뭉

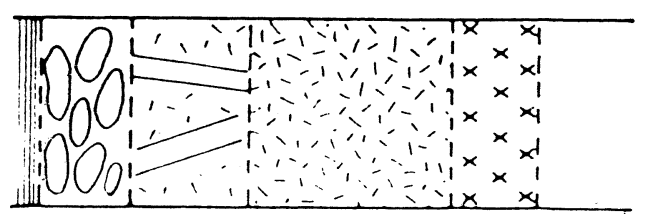

尚 


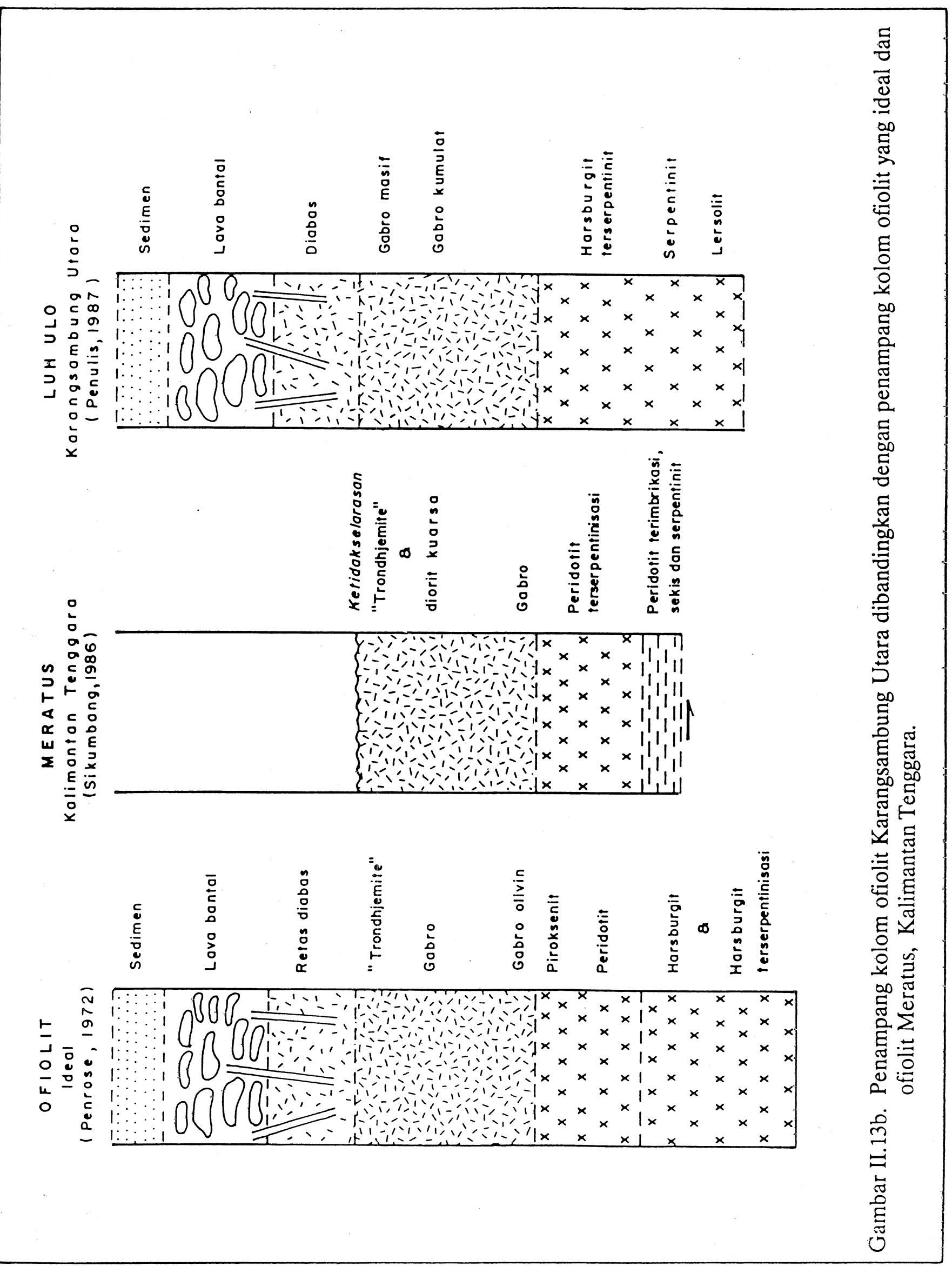


khususnya pada batuan mafis adalah mengetahui secara lebih pasti mengenai waktu pembentukan ofiolit di daerah penyelidikan; dengan demikian juga akan membantu di dalam merekonstruksi genesis ofiolit tersebut serta proses penempatannya. Batuan lainnya yang juga ditentukan umurnya dengan metode yang sama adalah dasit dan sekis mika. Hasil pentarikhan radiometri dengan K-Ar (Tabel II.1) menunjukkan bahwa batuan mafis (dalam hal ini basalt dan diabas) berumur $81 \pm 4,06 \mathrm{jt}$ dan $85,03 \pm 4,25 \mathrm{jt}$; sedangkan dasit berumur $67,71 \pm 3,39$ jt, batuan sekis mika diperoleh umur 101,71 $\pm 5,09 \mathrm{jt}$ dan 103,05 土5,15 jt. 


\section{BAB III \\ PETROGRAFI DAN MINERALOGI}

Batuan yang tercakup di dalam komplek ofiolit Karangsambung Utara ini terdiri dari batuan ultramafis (serpentinit, harsburgit terserpentinisasi, lersolit, dan lersolit hornblenda), gabro (kumulus dan non kumulus), diabas, dan basalt. Selain itu juga diketemukan batuan yang berkomposisi dasitik yang terdapat di daerah komplek ofiolit tersebut. Berikut ini pembahasan petrografi dan mineralogi dari masing-masing batuan.

\subsection{Petrografi}

Sejumlah lebih kurang 100 (seratus) conto batuan mencakup 90 (sembilan puluh) conto batuan mafis (gabro, diabas dan basalt) serta 10 (sepuluh) conto batuan ultramafis disayat untuk dianalisis secara mikroskopis; selain untuk mengamati variasi tekstur dan susunan mineralogi juga untuk memperoleh informasi tentang proses-proses sekunder yang dialami setiap batuan. Dengan demikian berarti juga membantu dalam interpretasi lanjut dari hasil analisis kimia batuan dan mineral, dari pentarikhan radiometri dan lain-lainnya.

\subsubsection{Serpentinit (harsburgit terserpentinkan)}

Batuan serpentinit yang diketemukan di dalam komplek ofiolit ini bertekstur sangat halus, dicirikan oleh kehadiran serpentin berserabut berwarna kehijauan. Adanya kenampakan tekstur bastite, mesh, serta sisa-sisa bentuk kristal primer menunjukkan bahwa batuan ini berasal dari batuan peridotit (lersolit atau harsburgit). Hadir sebagai mineral tambahan adalah kromit-Mg (Mg-chromite).

Hasil analisis unsur utama 3 (tiga) batuan serpentinit (SL3B, CD5A, dan CD49) secara keseluruhan (Tabel IV.1b) terlihat nilai H.D. (hilang dibakar) cukup tinggi, mencapai 13 - $14 \%$. Hal ini dapat dijelaskan dengan terbentuknya mineral serpentin (antigorit maupun krisotil) yang kaya akan gugusan $\mathrm{OH}$ sebagai hasil dari proses sekunder yang dialami oleh serpentinit (proses pengubahan hidrotermal, 
metamorfosis, ataupun proses pelapukan). Analisis mikroprob serpentin dari dua conto batuan serpentinit SL-3B dan CD-49 (Tabel III.1a dan III.1b) menunjukkan komposisi yang relatif sama dengan hasil analisis serpentin dari beberapa komplek ofiolit di dunia; kesamaan ini antara lain terlihat pada kandungan $\mathrm{SiO}_{2}=35-41 \%$ dan $\mathrm{MgO}_{\mathrm{g}}=36-41 \%$. Kadar krom di dalam serpentin dari conto $\mathrm{CD}-49$ lebih tinggi yaitu berkisar antara 9 - $11 \%$ sedangkan pada conto SL - 3B hanya mencapai $0,03 \%$ (300 ppm).

\subsubsection{Lersolit}

Batuan lersolit adalah batuan ultramafis yang dibentuk oleh olivin antara 40-60\%, piroksen sekitar 10\%, dan sedikit plagioklas (Hudges, 1983). Batuan lersolit di daerah ini dicirikan oleh tekstur kumulus, dimana olivin, piroksen, plagioklas dan kadang-kadang mineral opak bertindak sebagai kristal kumulus; sedangkan klinopiroksen serta hornblenda (pada lersolit hornblenda) merupakan interkumulus (Foto III.1). Ukuran butir bervariasi dari $1 \mathrm{~mm}-5 \mathrm{~mm}$; kadangkadang mencapai $7 \mathrm{~mm}$. Proses ubahan menghasilkan tremolit-aktinolit, serpentin, klorit dan mineral opak. Urat-urat halus dari serpentin, atau klorit seringkali teramati pada sayatan batuan lersolit.

Olivin terdapat berupa mineral tidak berwarna, kadang-kadang agak pucat berbentuk poligonal dengan sistem retakan yang tidak beraturan; ia mewakili kristal kumulus, dengan besar butir antara 1 - 1,5 mm, sehingga nampak sebagai inklusi di dalam mineral interkumulus yang berbutir lebih kasar. Hampir semua olivin yang dijumpai di dalam batuan ultramafis hadir sebagai pseudomorf serpentin, dengan atau tanpa tremolit-aktinolit dan mineral opak. Olivin yang masih segar dijumpai pada beberapa conto saja (a.l. conto LK.87A).

Piroksen yang hadir dalam batuan lersolit terdiri dari klinopiroksen (diopsid) dan ortopiroksen (hipersten). Diopsid pada umumnya berukuran lebih kasar (mencapai $7 \mathrm{~mm}$ lebih), dan bertindak sebagai kristal interkumulus maupun kristal kumulus (pada lersolit hornblenda). Gejala exsolution (Foto III.2) sering teramati pada klinopiroksen. Hipersten pada umumnya berukuran lebih halus sekitar 1,0 


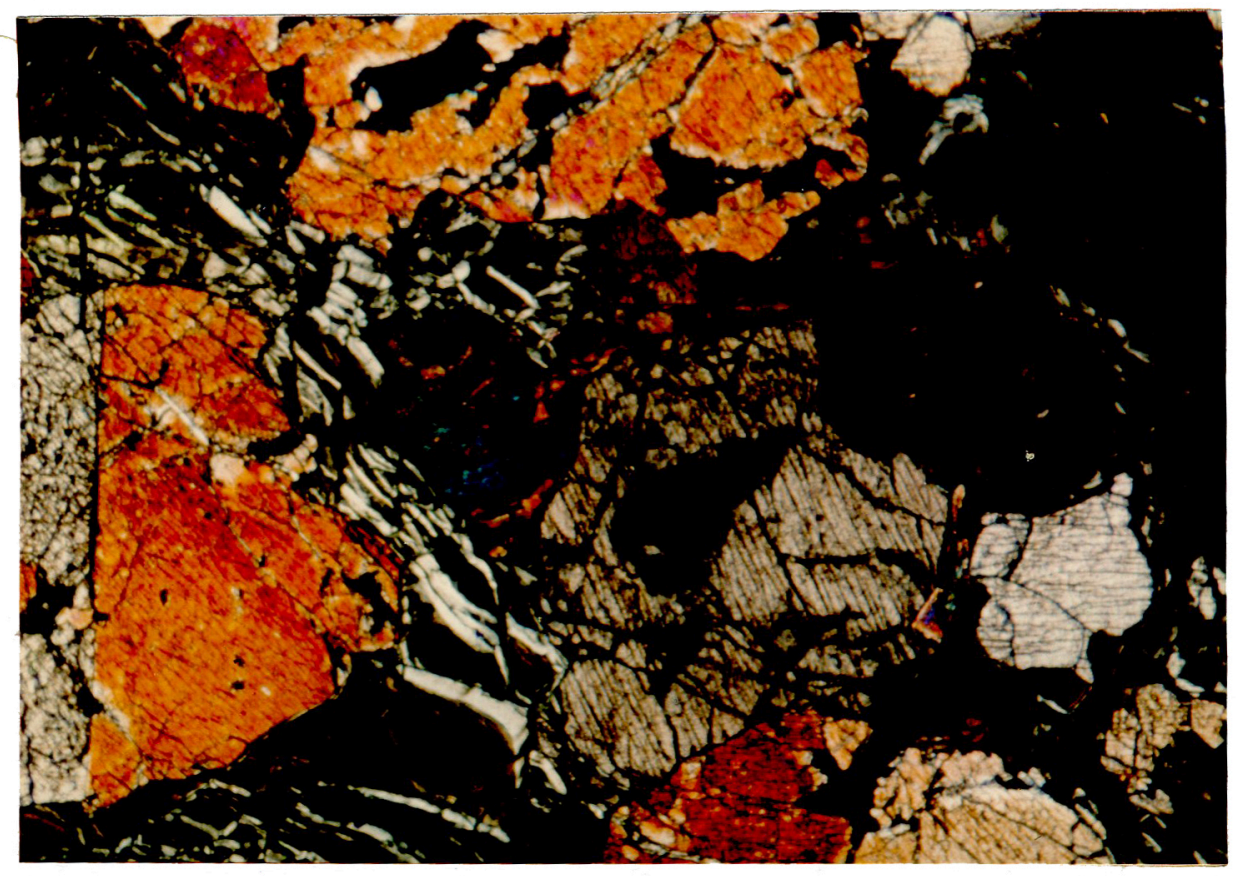

(a)
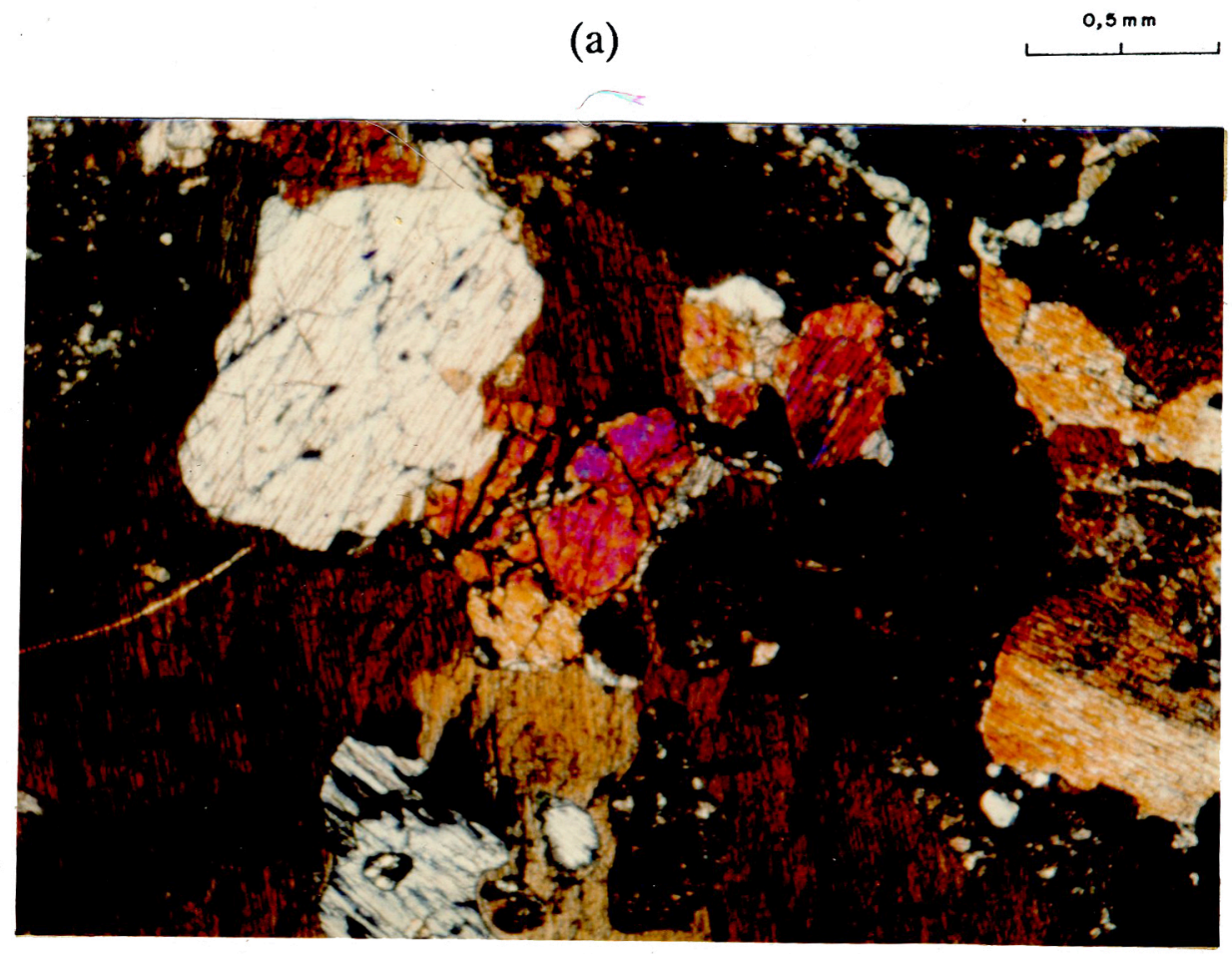

(b)

$0,5 \mathrm{~mm}$

Foto III.1. Keduanya adalah foto dari sayatan lersolit yang cukup segar. Batuan ini terdiri dari piroksen (warna putih keruh sampai kuning - kuning emas), dan olivin (warna merah jambu atau biru). Gejala serpentinisasi (kanan atas - kiri agak tengah) kadang-kadang teramati pada lersolit. Nikol bersilang. 


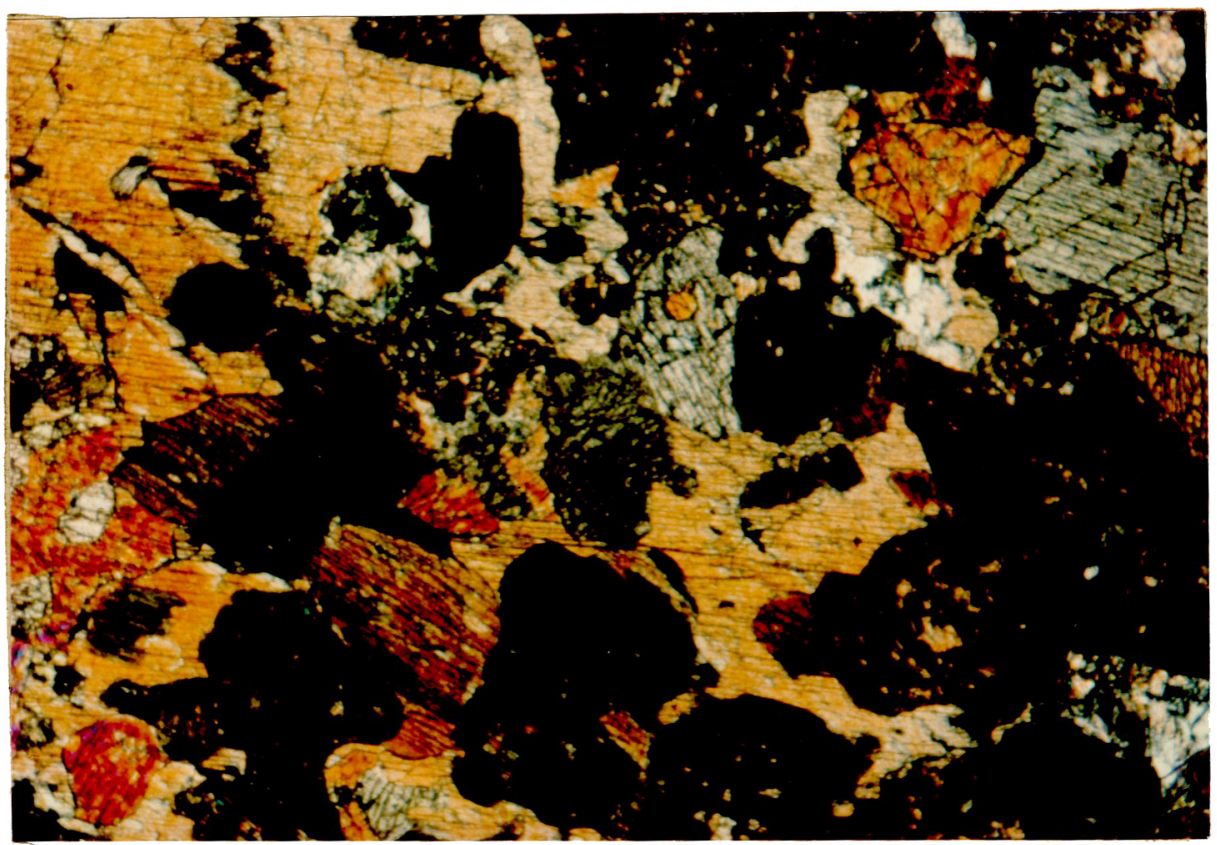

(a)

$0.125 \mathrm{~mm}$

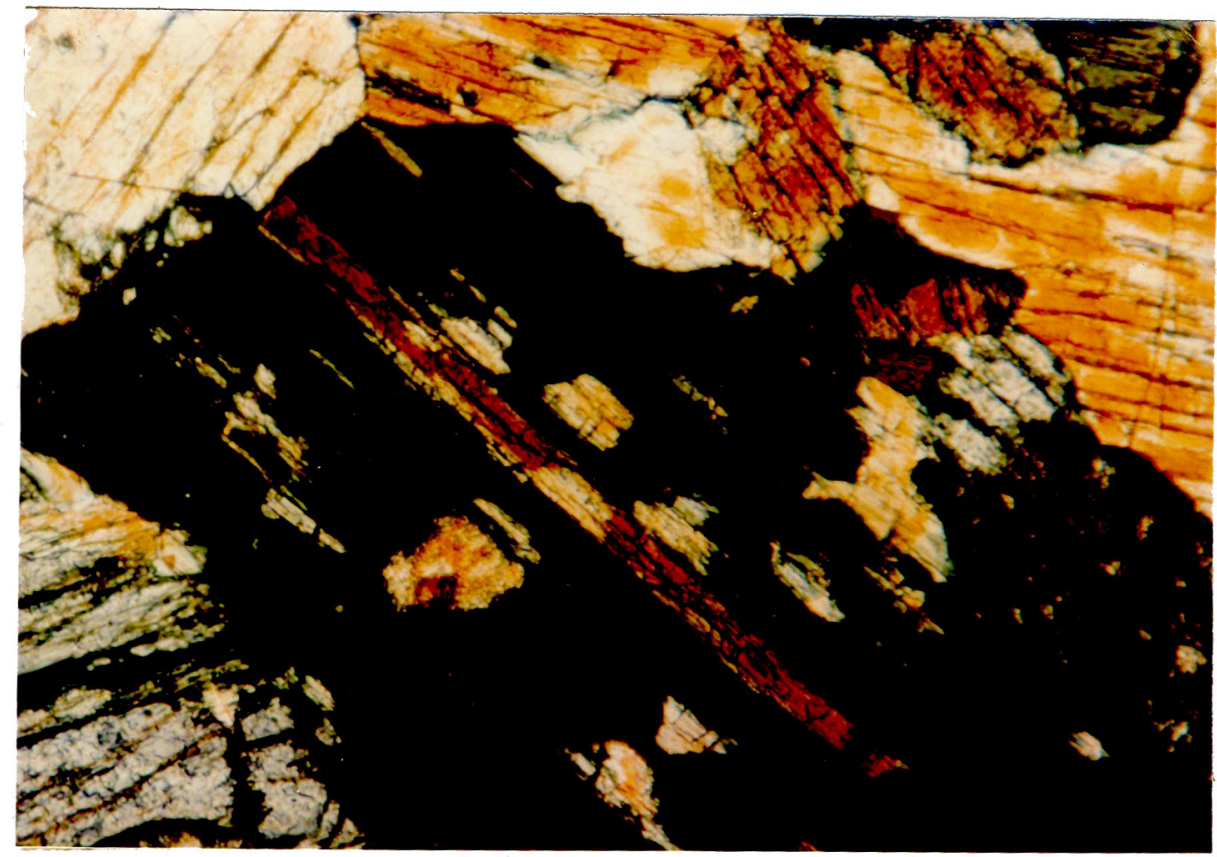

(b)

$0.125 \mathrm{~mm}$

Foto III.2. Sayatan lersolit yang memperlihatkan adanya gejala exsolution pada mineral klinopiroksen. Nikol bersilang. 
mm, sebagai kristal kumulus dalam keadaan telah terubah. Gejala ubahan piroksen menghasilkan tremolit-aktinolit, serpentin dan klorit.

Plagioklas hadir dalam jumlah sekitar 5\%, berupa kristal subhedral bersifat agak keruh akibat adanya bercak-bercak serisit-lempung sebagai mineral ubahan. Mineral ini hadir sebagai kristal kumulus berukuran halus (sekitar 1,5 mm).

Gejala albitisasi kadang-kadang teramati pada beberapa kristal plagioklas; jejak kembar Carlsbad-Albit juga terlihat pada bagian-bagian kristal yang belum terubah.

Hornblenda sebagai mineral primer hanya dijumpai pada beberapa conto batuan saja; dicirikan oleh warna coklat kekuningan, pleokroisme kuat, berukuran relatif lebih kasar (mencapai $5 \mathrm{~mm}$ ). Dalam hal ini hornblenda hadir sebagai kristal interkumulus, dengan piroksen, olivin, serta mineral opak hadir sebagai inklusi poikilitik. Proses ubahan mineral hornblenda menghasilkan serabut aktinolit berwarna hijau.

Mineral tambahan yang dijumpai dalam batuan lersolit mencakup mineral opak dan sfen berukuran sangat halus (tidak lebih dari 0,3 mm), sebagai inklusi di dalam mineral mafis primer.

\subsubsection{Gabro}

Batuan gabro di daerah Karangsambung Utara pada umumnya bertekstur ekuigranuler, berukuran sedang - sangat kasar (antara 1,5 - $5 \mathrm{~mm}$; beberapa mencapai ukuran $10 \mathrm{~mm}$ ); terdiri dari gabro yang bertekstur non kumulus dan kumulus. Pada gabro yang bertekstur non kumulus biasanya memperlihatkan tekstur hypidiomorfik granuler dengan kenampakan adanya pertumbuhan bersama antara plagioklas dan piroksen (tekstur ofitik \& sub ofitik); lihat Foto III.3a dan b. Gabro kumulus umumnya dicirikan oleh plagioklas sebagai kristal kumulus sedangkan piroksen, amfibol ataupun mineral opak bertindak sebagai kristal interkumulus; pada beberapa conto gabro (conto KC - 8C) dijumpai perselingan antara mineral mafis dan plagioklas membentuk perlapisan (Foto III.3c \& d). Komposisi utama batuan terdiri dari plagioklas dan piroksen; amfibol 


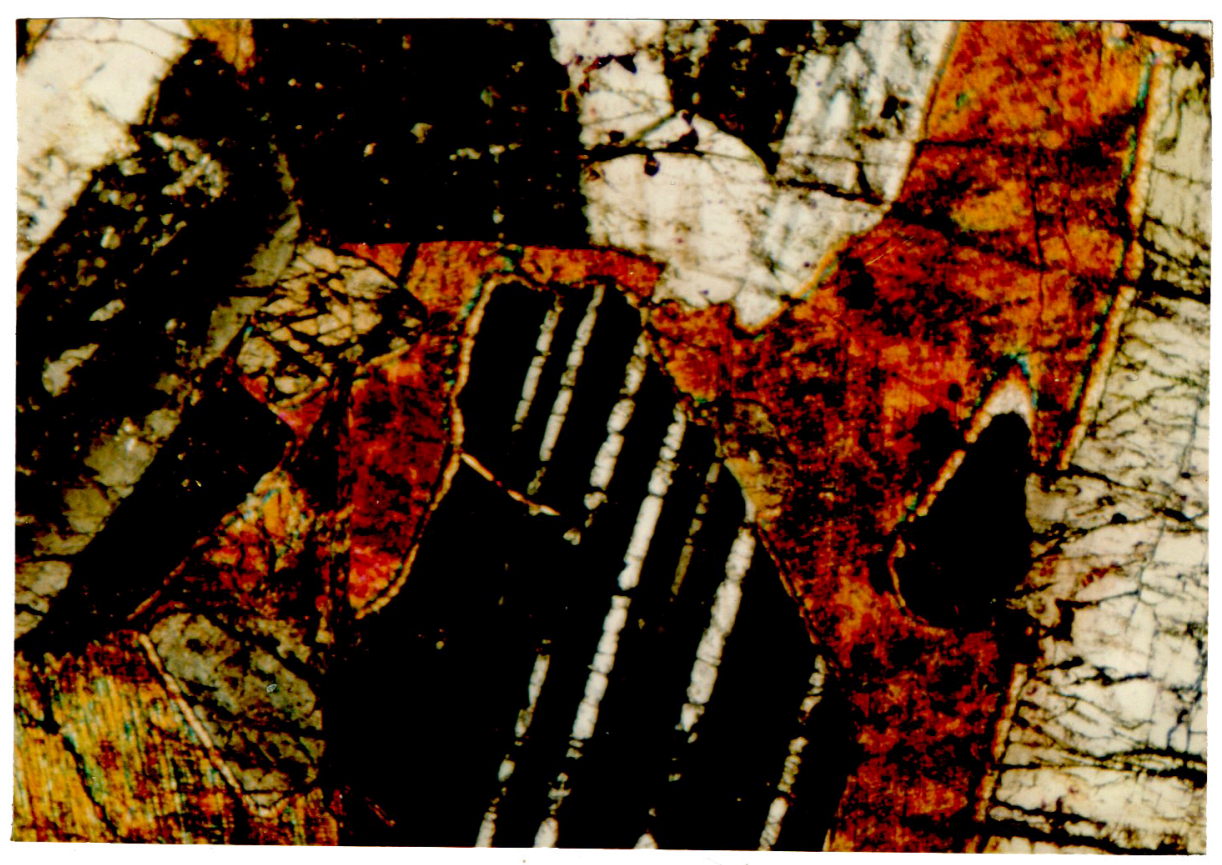

(a)

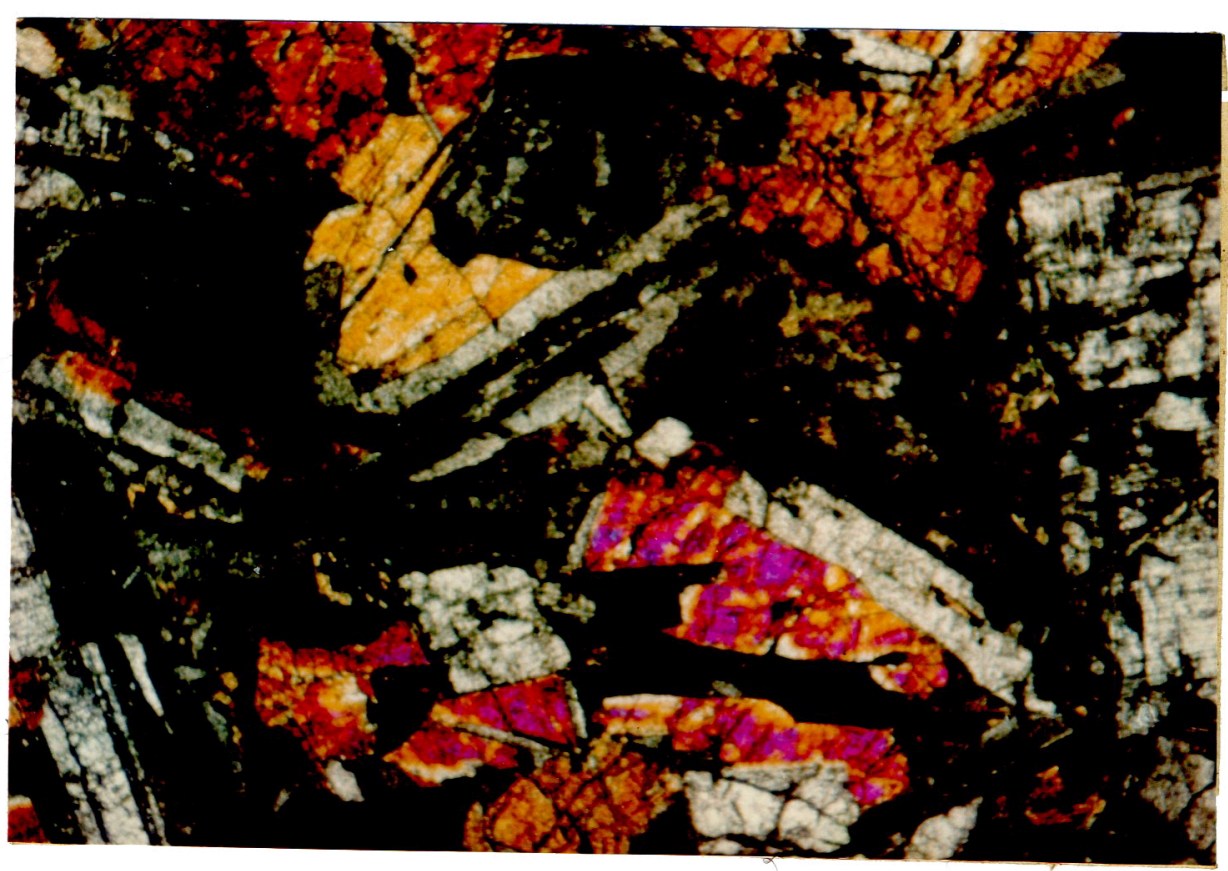

(b)

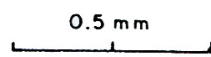

Foto III.3. Sayatan gabro non kumulus, bertekstur ofitik - sub ofitik dengan variasi ukuran butir kasar sampai halus. Nikol bersilang. 


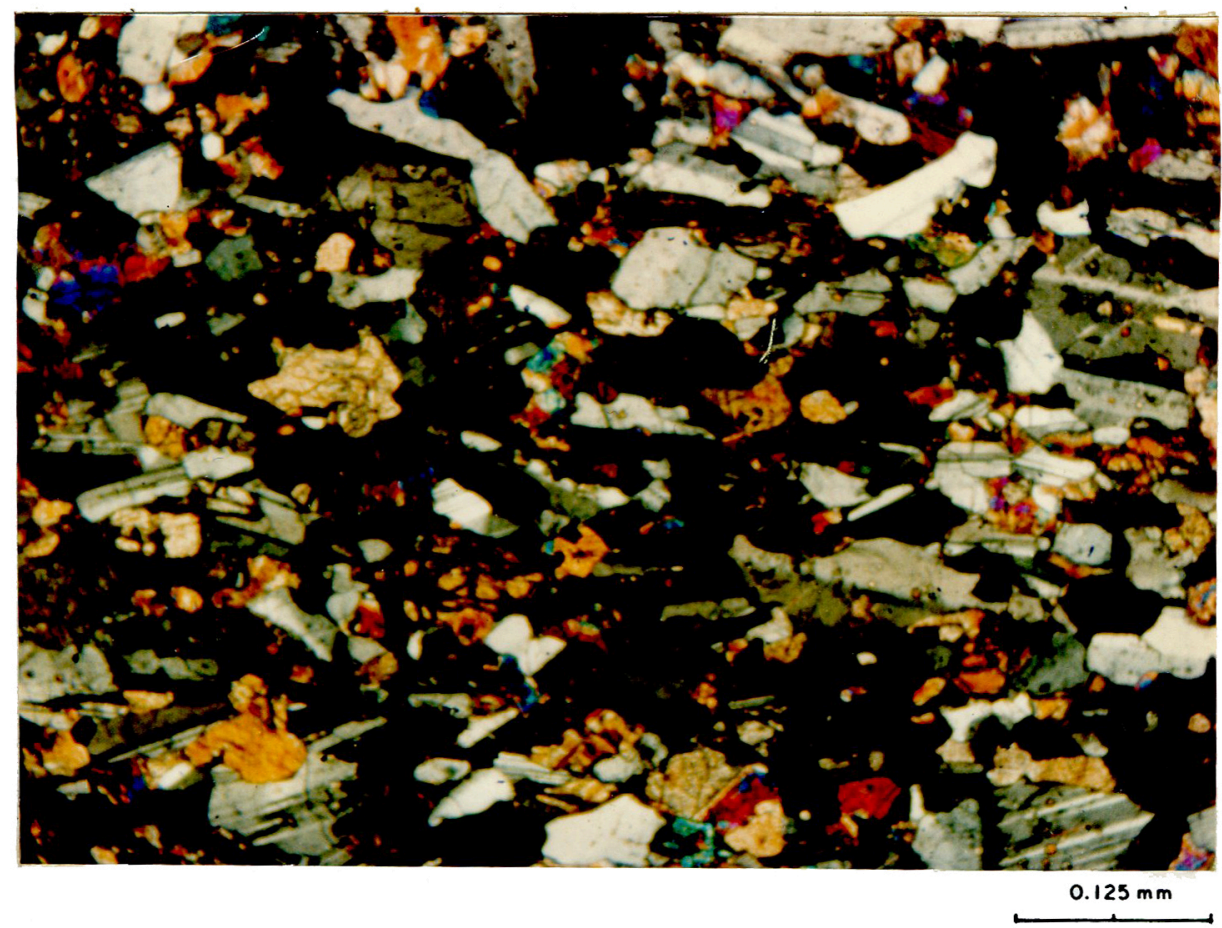

Foto III.3c. Sayatan gabro kumulus yang cukup segar, memperlihatkan perlapisan yang dibentuk oleh perselingan antara plagioklas (abu-abu, berkembar) dan piroksen (kuning - kuning emas). Nikol bersilang.

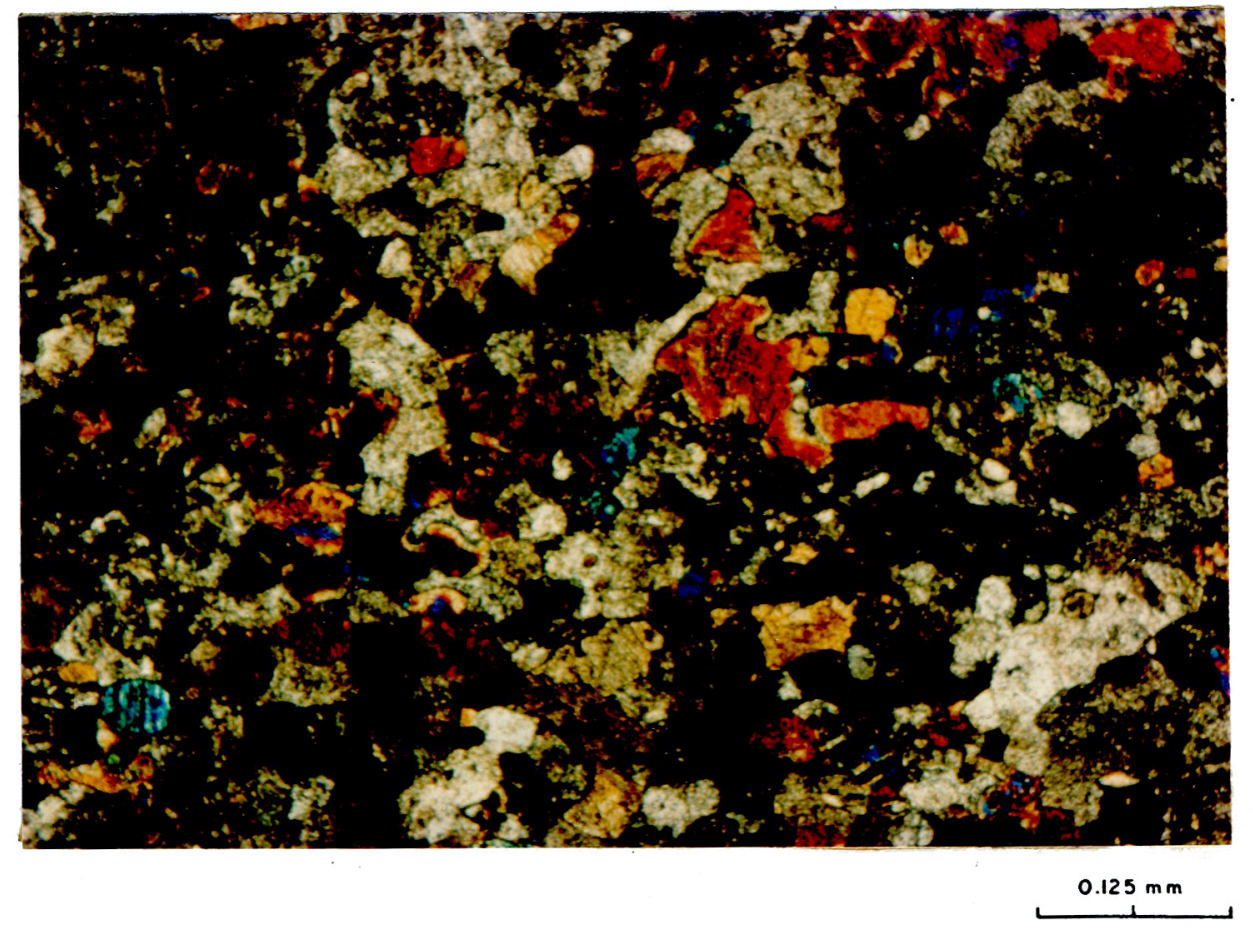

Foto III.3d. Memperlihatkan batuan yang sama dimana plagioklas sebagai kristal interkumulus telah terubah menjadi serisit (bersifat keruh). Sedangkan piroksen mewakili kristal kumulus di dalam sayatan gabro ini. Nikol bersilang. 
hanya dijumpai pada beberapa conto batuan (a.l. ST.48, ST.14A, ST.81). Mineral opak (ilmenit dan magnetit) hadir sebagai tambahan. Sebagian besar batuan gabro telah terubah menghasilkan himpunan mineral serisit, lempung, albit sekunder, epidot, tremolit, aktinolit, serpentin, prehnit, klorit dan karbonat. Gejala rekristalisasi ini seringkali disertai oleh gejala deformasi, yang ditandai dengan adanya batas kristal yang bergerigi, pemadaman bergelombang, pelengkungan bidang belahan, maupun retakan-retakan yang biasanya diisi oleh prehnit, serpentin, epidot, kuarsa, atau karbonat (Foto III.4a \& b).

Plagioklas hadir sebagai komponen terbanyak di dalam gabro yang merupakan kristal kumulus pada gabro bertekstur kumulus; sedangkan pada gabro yang non kumulus mineral ini bersama piroksen membentuk tekstur ofitik atau sub ofitik. Ukuran butirannya berkisar antara 1,5 - $6 \mathrm{~mm}$, hadir berupa kristal prismatik ataupun berupa pelat-pelat memanjang. Gejala kembar Carlsbad-Albit merupakan kenampakan umum teramati pada plagioklas. Penentuan jenis plagioklas dari analisis mikroprob beberapa conto batuan (CD.7 \& PS.16) diperoleh hasil An berkisar antara 52 - 67 (jenis labradorit); Gambar III.1. Proses ubahan plagioklas menghasilkan serisit, lempung dan karbonat. Gejala albitisasi dan juga penggantian oleh epidot atau prehnit seringkali dijumpai pada mineral ini.

Piroksen yang terdapat pada gabro terdiri dari klinopiroksen dan ortopiroksen. Hadir berupa kristal prismatik subhedral berwarna bening sampai kecoklatan. Ortopiroksen diwakili oleh hipersten yang biasanya lebih terubah dibandingkan dengan klinopiroksen; pada mineral hipersten yang relatif segar masih terlihat adanya gejala exsolution dimana klinopiroksen terdapat berupa bercak-bercak halus di dalamnya. Dari analisis mikroprob dari conto CD.7 dan PS.16 diperoleh jenis klinopiroksen bervariasi dari W045En46Fs9. sampai Wo25En56Fs11 atau jenis endiopsid - augit (Gambar III.2). Jenis klinopiroksen lain dalam hal ini tidak teranalisis karena umumnya telah terubah. Proses ubahan dari piroksen menghasilkan uralit, tremolit, aktinolit, klorit dan serpentin. Gejala 


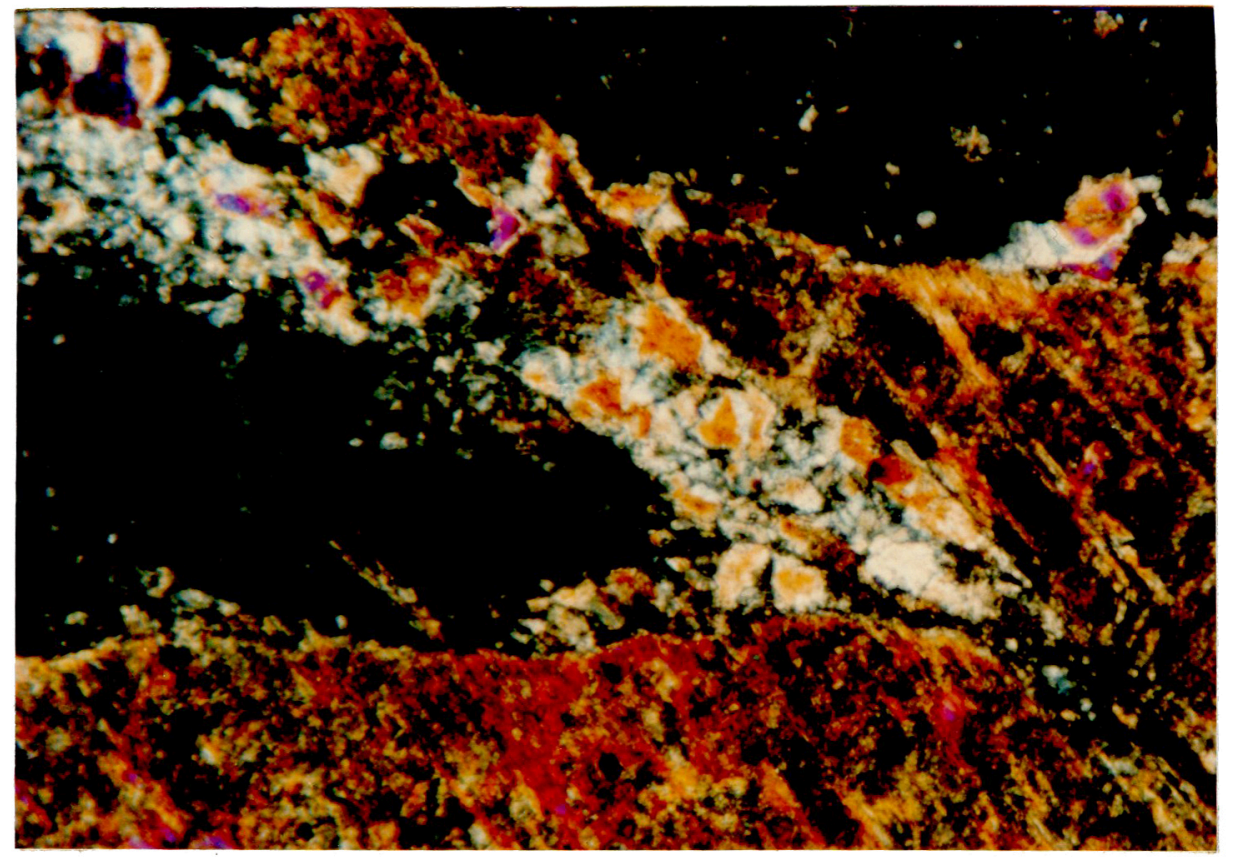

( a )

$0.125 \mathrm{~mm}$

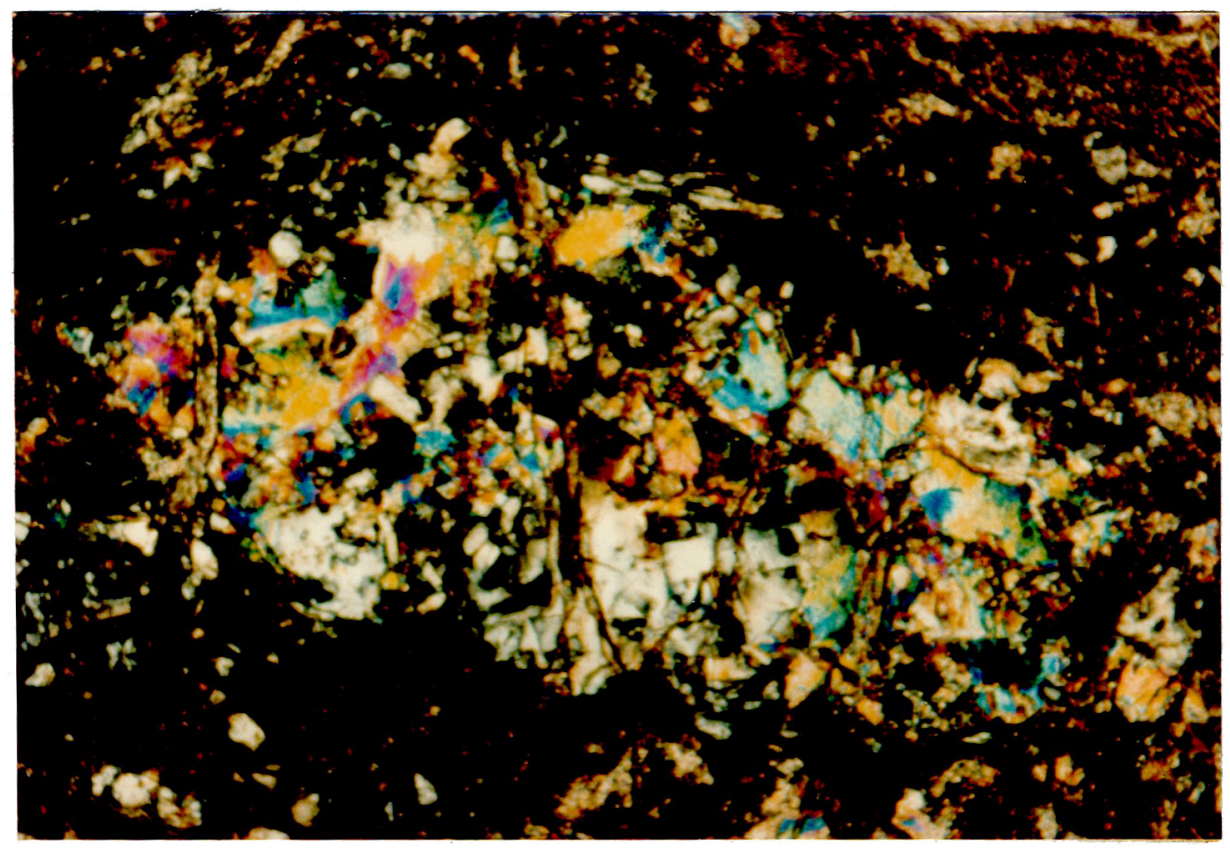

( b )

$0.125 \mathrm{~mm}$

Foto III.4. Sayatan gabro yang memperlihatkan rekristalisasi akibat pengubahan serta deformasi. Perhatikan adanya agregat prehnit mengisi retakan (a), atau mengganti sebagian plagioklas (b), Kehadiran karbonat berupa barik maupun bercak juga terlihat pada foto. Nikol bersilang. 


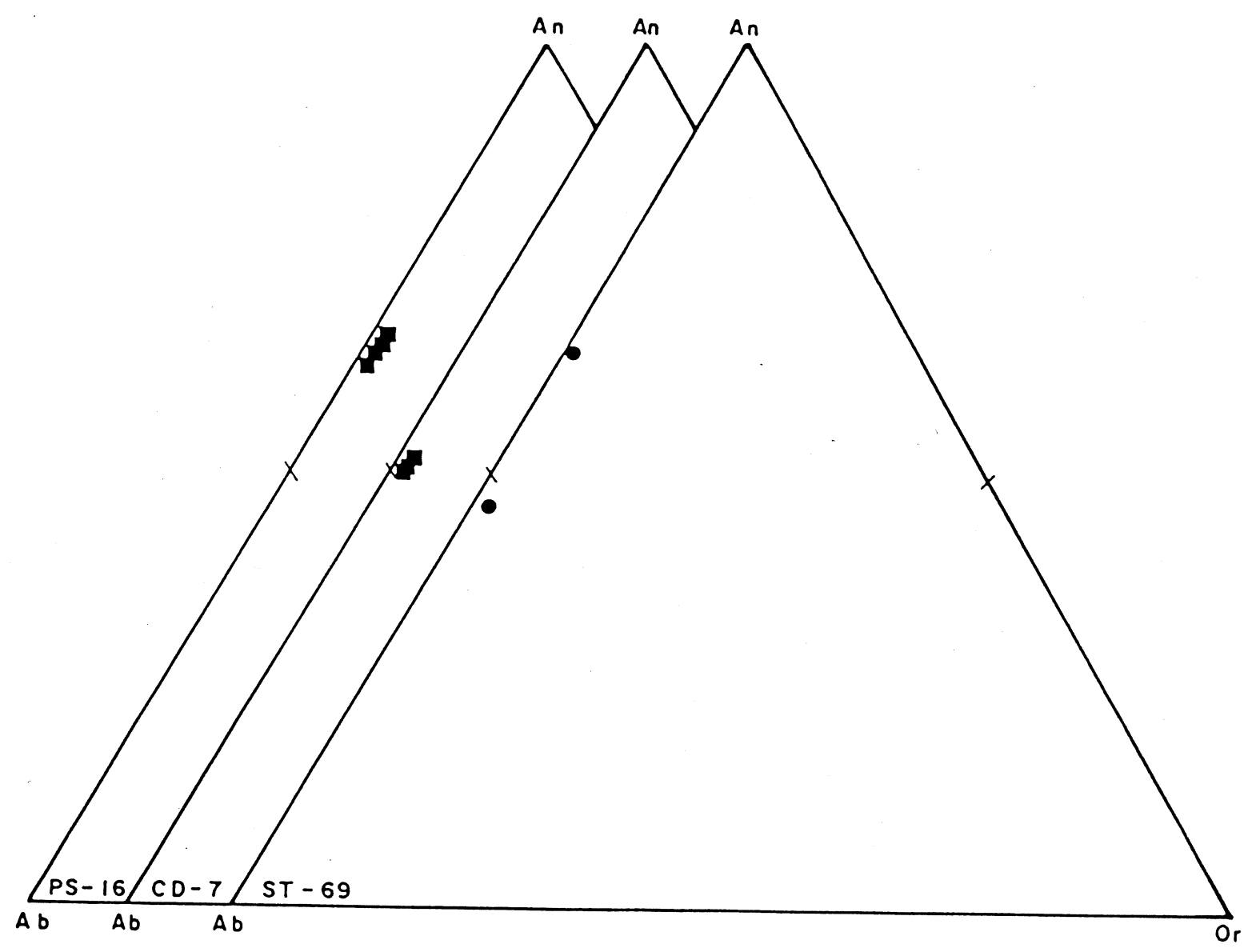

Gambar III.1. Perajahan mineral-mineral plagioklas dari basalt (ST-69) dan gabro (CD-7, PS-26), Karangsambung Utara di dalam diagram
An-Ab-Or. 


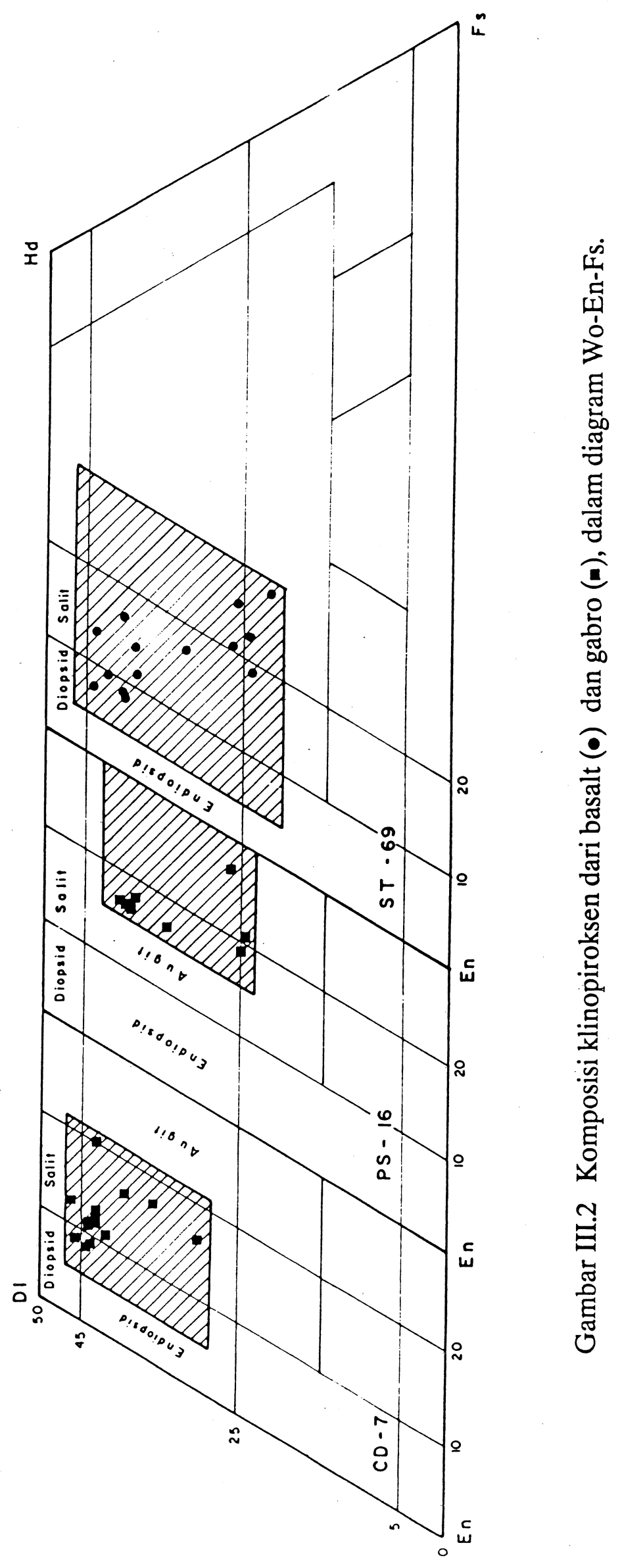


penggantian oleh epidot juga sering teramati páda klinopiroksen.

Hornblenda hanya diketemukan pada beberapa conto berupa kristal prismatik berwarna coklat kekuningan atau hijau, dengan pleokroisme kuat. Pada batuan gabro hornblenda seringkali terlihat adanya gejala tumbuh bersama antara hornblenda berwarna coklat dengan piroksen. Hornblenda nampak relatif lebih segar dibandingkan dengan mineral mafis yang lain; hanya beberapa kristal saja yang terubah menghasilkan uralit/hornblenda aktinolitik (berwarna hijau). Dari analisis mikroprob hornblenda menunjukkan kadar $\mathrm{CaO} 11,86 \%, \mathrm{MgO} 17,31 \%$, dan $\mathrm{FeO} 10,48 \%$. Sedangkan $\mathrm{K}_{2} \mathrm{O}$ dan $\mathrm{Na}_{2} \mathrm{O}$ sangat rendah, berturut-turut $0,05 \%$ dan $0,61 \%$ (lihat Tabel III-1).

Mineral opak selalu hadir pada hampir semua sayatan gabro yang diwakili oleh magnetit, dan kadang-kadang ilmenit; dijumpai berupa kristal primer berbentuk subhedral, ataupun sebagai mineral sekunder yang biasanya berasosiasi

dengan mineral-mineral hasil ubahan lainnya. Kehadiran ilmenit yang relatif jarang atau sedikit ini dicerminkan oleh kadar $\mathrm{TiO}_{2}$ yang relatif rendah, sekitar 0,3\% - 0,4\% (Tabel III.2). Ti-magnetit menunjukkan jenis yang kaya akan unsur $\mathrm{TiO}_{2}$ mencapai 51,43\% - 54,11\% dengan kadar MnO berkisar antara 10\%-29,48\%.

Mineral sedikit yang teramati pada gabro adalah sfen dengan kadar $\mathrm{TiO}_{2}$ mencapai 92,74\%, $\mathrm{MnO} 0,08 \%$, serta $\mathrm{Cr}_{2} \mathrm{O}_{3}$ rendah sekali sekitar 4 ppm.

\subsubsection{Diabas dan basalt}

Diabas dan basalt mewakili batuan mafis yang berukuran halus di dalam komplek ini. Diabas dicirikan oleh tekstur ofitik/diabasik dan tekstur intersertal dengan ukuran butir maksimum mencapai $1,5 \mathrm{~mm}$; basalt pada umumnya memperlihatkan tekstur intergranuler dengan ukuran butir tidak lebih dari $1 \mathrm{~mm}$ (Foto III.5a dan b). Tekstur porfiritik kadang-kadang terlihat pada kedua batuan tersebut dengan plagioklas dan piroksen sebagai fenokris. Komposisi terdiri dari plagioklas, piroksen, mineral opak serta mineral sekunder seperti serisit, lempung, amfibol sekunder (tremolit, aktinolit dan uralit), prehnit, epidot, albit, kuarsa, klorit, serpentin, serta karbonat. Pada batuan yang telah terubah / terrekristalisasi 


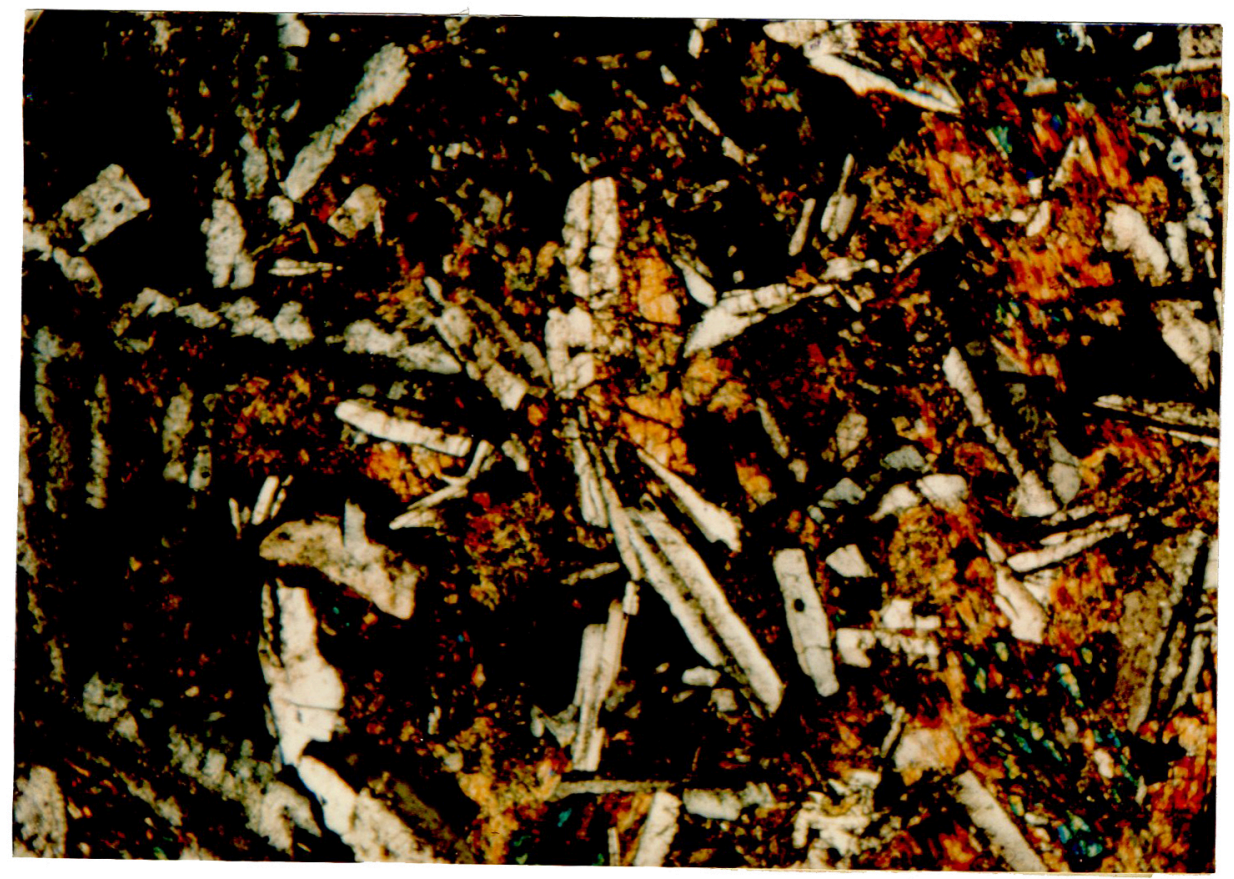

(a)

$0.5 \mathrm{~m} \mathrm{~m}$

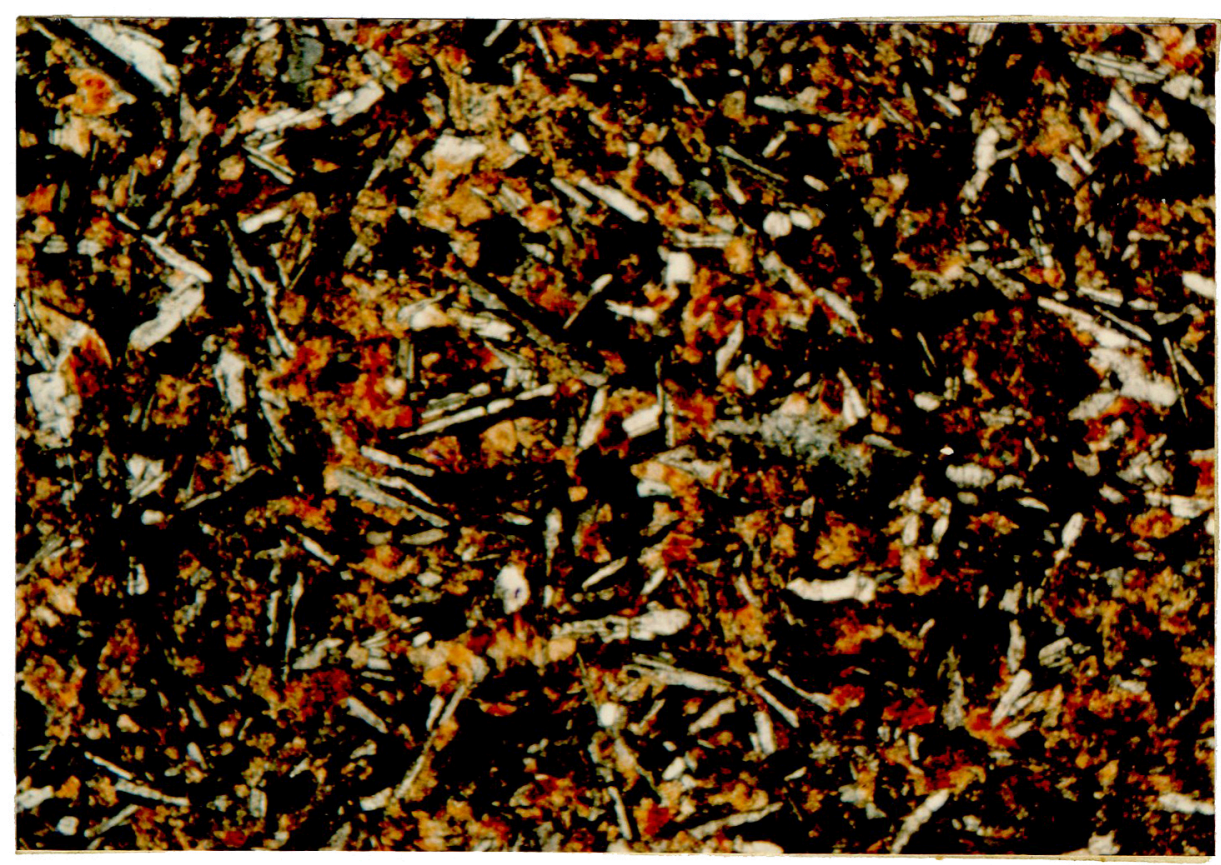

(b)

$0.5 \mathrm{~m} \mathrm{~m}$

Foto III.5. Sayatan diabas berbutir sedang dan dicirikan oleh tekstur ofitik /diabasik (foto a). Sedangkan foto b memperlihatkan basalt berbutir lebih halus, bertekstur intergranular - intersertal. Nikol bersilang. 
umumnya memperlihatkan kemas allotriomorfik granuler, pemadaman bergelombang serta retakan yang sebagian terisi oleh mineral sekunder (Foto III.6).

Plagioklas hadir berupa pelat-pelat halus, atau mikrolit pada basalt dan berupa kristal prismatik pada diabas. Pada kristal plagioklas yang berukuran lebih kasar (termasuk fenokris plagioklas) terlihat adanya gejala kembar Carlsbad - Albit dan kehadiran dari bercak-bercak mineral sekunder seperti serisit, lempung dan karbonat. Gejala albitisasi sangat umum dijumpai pada plagioklas dari batuan mafis yang berukuran halus. Beberapa batuan diabas dan basalt memperlihatkan adanya gejala penggantian sebagian (partial replacement) plagioklas oleh prehnit atau epidot. Penentuan mikrolit plagioklas dari satu conto batuan (ST.69) diperoleh hasil An46 (andesin) dan An67 (labradorit); lihat Gambar III.1. Adanya jenis plagioklas yang lebih asam (An46) adalah akibat dari proses pengubahan sekunder.

Piroksen di dalam batuan mafis halus ini diwakili oleh klino piroksen dan ortopiroksen. Keduanya dijumpai berupa kristal prismatik berwarna kehijauanagak kecoklatan. Ortopiroksen hadir sebagai fenokris berukuran mencapai $1 \mathrm{~mm}$, dan berupa butiran-butiran subhedral diantara pelat-pelat/ mikrolit-mikrolit plagioklas pada masadasar; klinopiroksen umumnya hadir pada masadasar saja. Perajahan pada diagram Wo-En-Fs dari hasil analisis mikroprob klinopiroksen pada masadasar menunjukkan jenis endiopsid - augit dengan komposisi berkisar antara Wo44En43Fs13 sampai Wo ${ }_{39} \mathrm{En}_{48} \mathrm{Fs}_{13}$ (Gambar III.2). Mineral ortopiroksen tidak dapat ditentukan jenisnya mengingat hampir semua ortopiroksen yang dijumpai dalam batuan telah terubah sebagian ataupun seluruhnya menjadi mineral sekunder. Proses ubahan piroksen menghasilkan aktinolit/ tremolit, klorit, dan serpentin. Mineral opak umumnya hadir sebagai mineral tambahan; dari analisis mikroprob diperoleh jenis ilmenit yang sebagian besar telah terubah menjadi rutil dan hematit. Kehadiran ilmenit relatif agak jarang atau dalam jumlah sedikit; hal ini juga tercermin dari kadar $\mathrm{TiO}_{2}$ pada basalt berkisar antara $0,9-1,11 \%$.

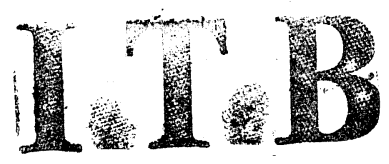




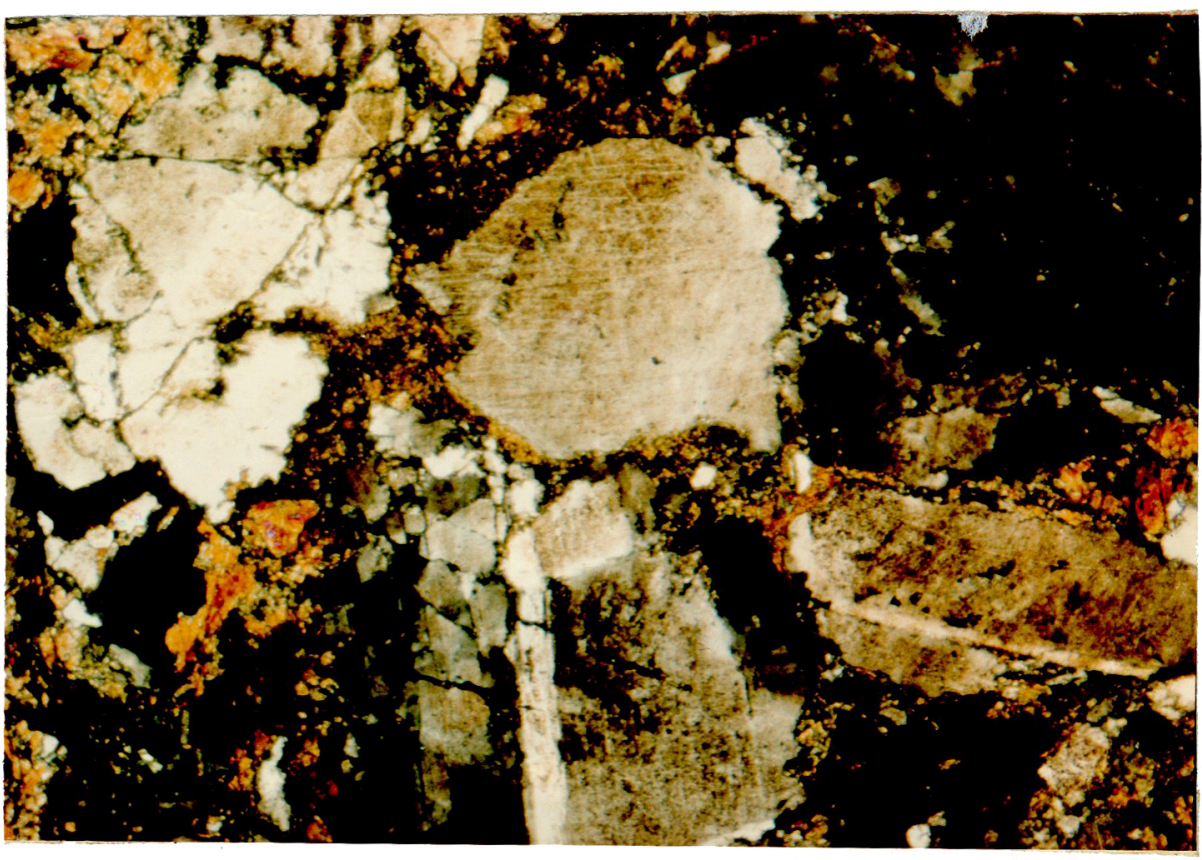

(a)

$0.125 \mathrm{~mm}$

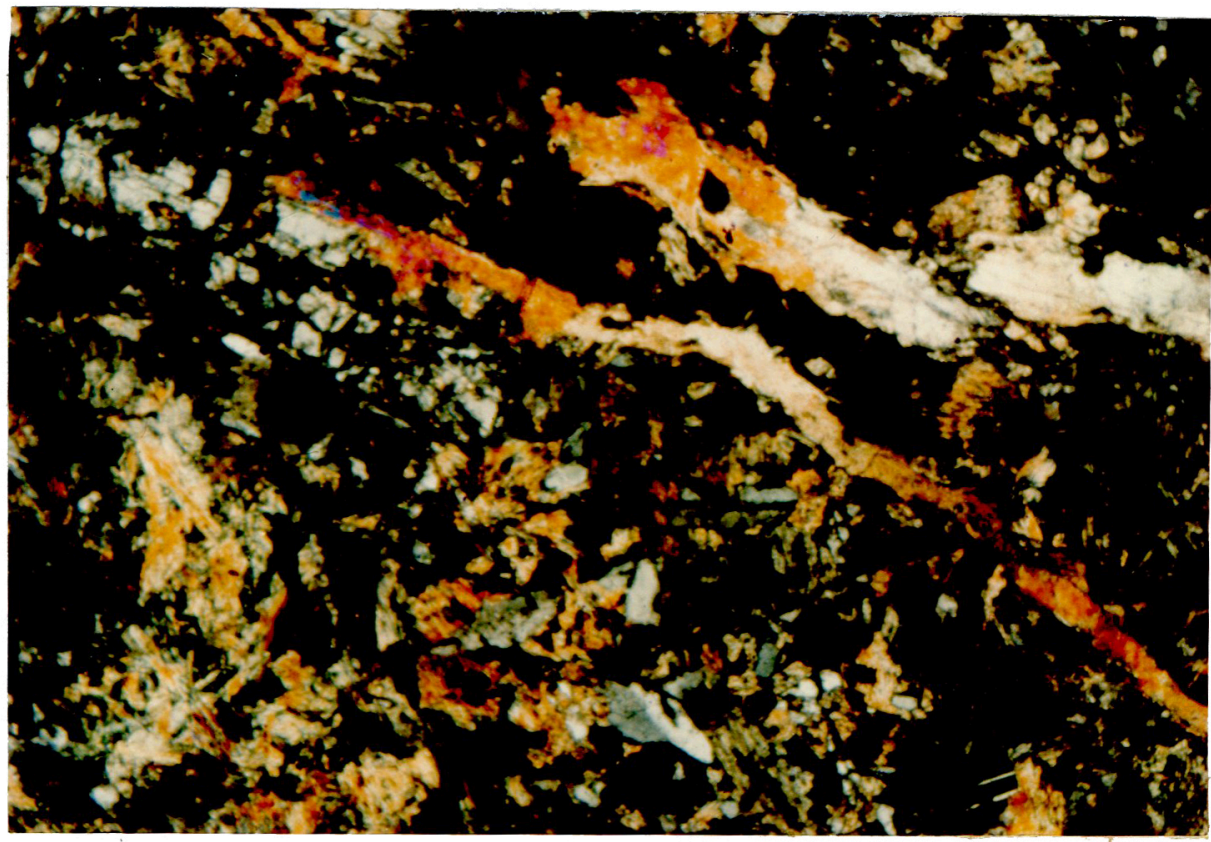

(b)

$0.125 \mathrm{~m} \mathrm{~m}$

Foto III.6. Sayatan diabas yang memperlihatkan gejala deformasi serta pengubahan. Perhatikan adanya barik-barik prehnit yang memotong batuan pada foto III.6b. Nikol bersilang. 


\subsubsection{Dasit}

Batuan dasit daerah penyelidikan dicirikan oleh warna abu-abu dengan bintik-bintik (mencapai ukuran $6 \mathrm{~mm}$ ) berwarna putih tersebar merata. Secara petrografis batuan ini memperlihatkan tekstur porfiritik dengan fenokris plagioklas dan felspar alkali, kuarsa, dan sedikit mika (flogopit) tertanam di dalam masadasar yang sangat halus (Foto III.7). Masadasar dibentuk oleh agregat sangat halus (kurang dari 0,1 mm) terdiri dari felspar, kuarsa anhedral, serta masa lempungan. Batuan dasit ini memperlihatkan proses pengubahan yang tidak begitu kuat, menghasilkan serisit, sedikit lempung, klorit, serta karbonat. Plagioklas hadir sebagai fenokris berukuran mencapai lebih dari $5 \mathrm{~mm}$ dan juga berupa kristal sangat halus pada masadasar. Fenokris plagioklas pada umumnya berbentuk subhedral, dicirikan oleh kembar polisintetik; beberapa diantaranya terubah sebagian menjadi serisit. Proses albitisasi atau penggantian oleh karbonat kadang-kadang teramati pada kristal plagioklas. Felspar alkali pada umumnya bersifat lebih jernih daripada plagioklas. Beberapa fenokris felspar alkali memperlihatkan pengubahan menjadi lempung.

Kuarsa dijumpai berupa kristal subhedral - anhedral berukuran sedang sampai kasar (mencapai lebih dari $5 \mathrm{~mm}$ ) sebagai fenokris dan sebagian besar hadir berupa kristal anhedral sangat halus pada masadasar. Sebagian besar fenokris kuarsa dicirikan oleh gejala korosi masadasar dan memperlihatkan pemadaman agak bergelombang.

Flogopit hadir sebagai fenokris berupa kristal prismatik memanjang/tabular, berwarna agak kecoklatan berbutir halus (sekitar $0,5 \mathrm{~mm}$ ). Sebagian besar dari mineral tersebut telah mengalami pengubahan menjadi serabut klorit berwarna kehijauan. Mineral tambahan yang dijumpai dalam batuan dasit mencakup mineral opak dan sirkon. Mineral opak dijumpai berupa mikrofenokris (mencapai $0,1 \mathrm{~mm}$ ) serta berupa butiran sangat halus di dalam masadasar; sedangkan sirkon hanya dijumpai beberapa butir saja di dalam masadasar. 


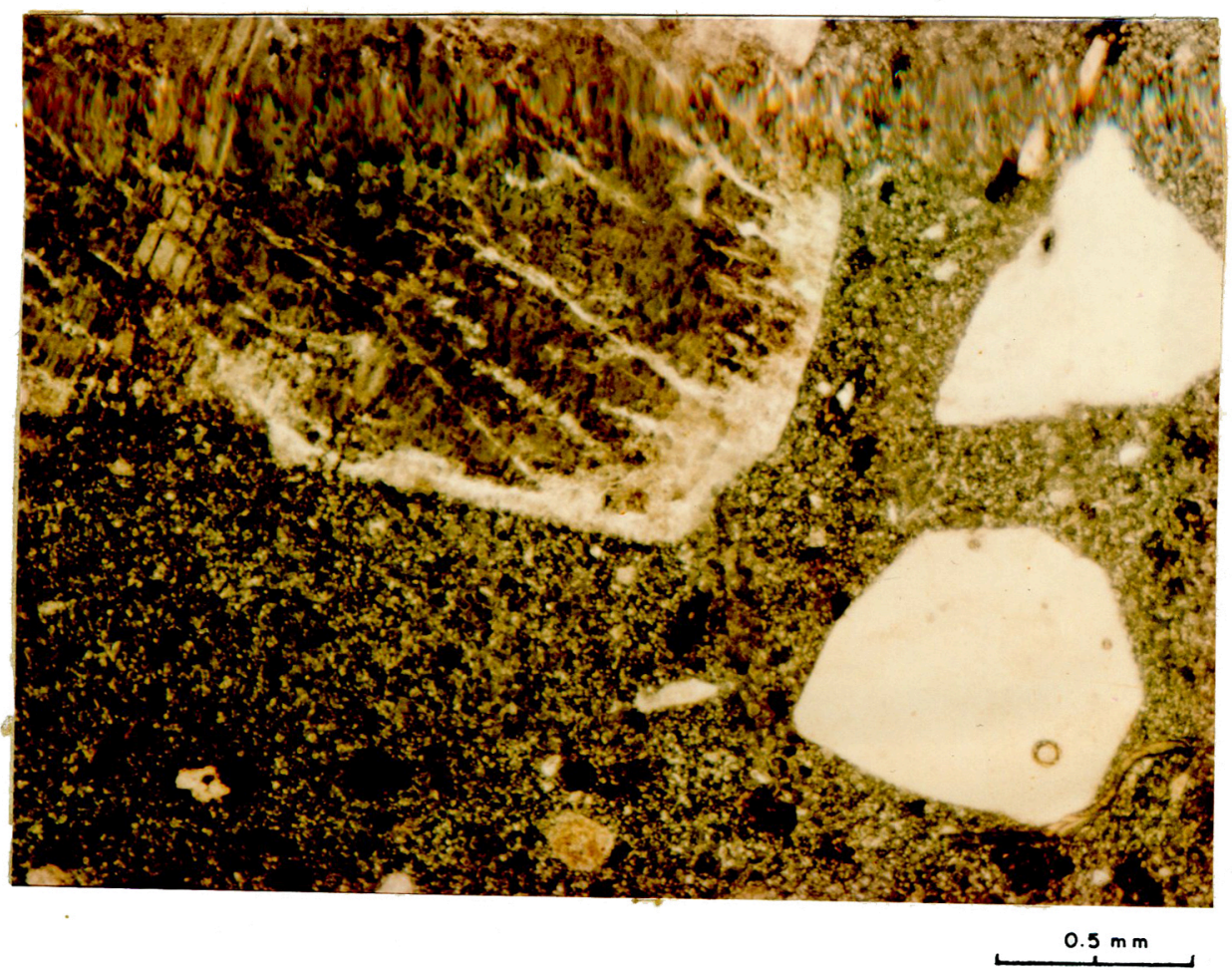

Foto III.7a. Sayatan dasit bertekstur porfiritik terdiri dari fenokris plagioklas (keruh) dan kuarsa (putih) tertanam di dalam masadasar sangat halus. Perhatikan fenokris plagioklas (kanan atas) yang telah mengalami proses albitisasi (barik-barik atau bercak putih). Nikol bersilang.

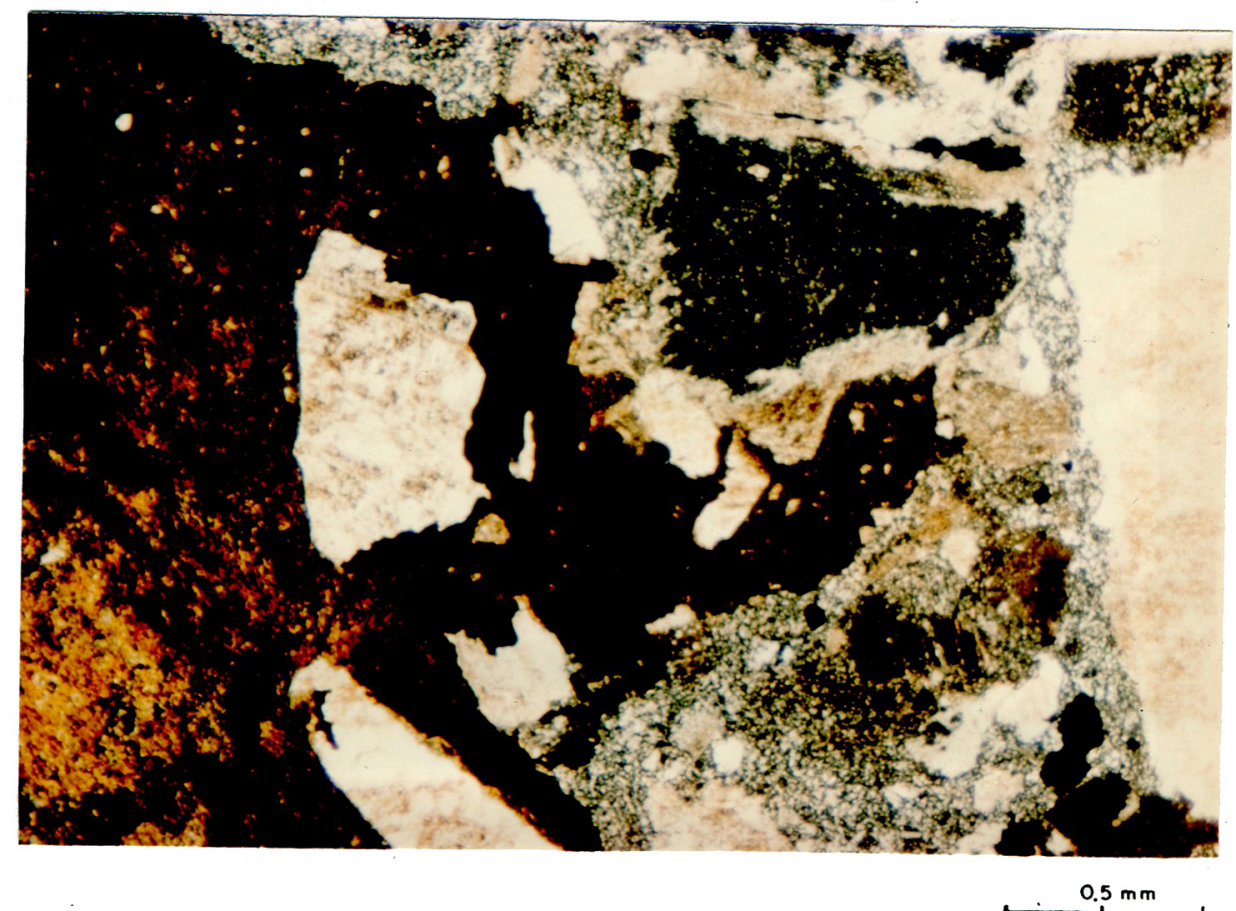

FotoIII.7b. Sayatan kontak antara batulempung pasiran (kiri, warna coklat kekuningan) dengan dasit (kanan). Perhatikan adanya fragmen-fragmen felspar (putih keruh) dari dasit tercampur di dalam batulempung pasiran. Nikol bersilang. 


\subsection{Mineralogi}

Tiga batuan yaitu CD7, PS16, dan ST69 diambil untuk dianalisis mineralnya (terutama klinopiroksen dan plagioklas) dengan menggunakan mikroprob yang hasilnya dapat dilihat pada Tabel III.1 sampai dengan III.6.

\subsubsection{Komposisi Klinopiroksen}

Karakteristik petrologi serta geokimia dari batuan volkanis berkaitan langsung dengan tatanan tektoniknya, meskipun beberapa proses pengubahan yang terjadi setelah penempatan batuan tersebut (mencakup pengubahan hidrotermal serta metamorfosis) dapat mengaburkan karakter mineralogi dan geokimia primer dari batuan; hal ini dapat menghambat di dalam rekonstruksi tentang evolusi tektoniknya. Namun demikian beberapa penelitian terhadap batuan volkanis yang telah terubah menunjukkan bahwa klinopiroksen merupakan satu-satunya mineral feromagnesia yang seringkali masih utuh sehingga dapat digunakan untuk mengidentifikasi afinitas magma asal serta lingkungan pembentukannya. Maka dari itu analisis komposisi klinopiroksen merupakan salah satu metode penelitian yang sangat penting untuk dilakukan.

Dari analisis petrografi terlihat adanya klinopiroksen baik sebagai fenokris maupun berupa butiran sangat halus pada masadasar. Mengingat tidak diketemukannya mineral piroksen pada masa-dasar yang cukup segar maka tidak dilakukan analisis terhadap piroksen pada masadasar. Sedangkan di dalam ketiga conto batuan termaksud di atas yaitu CD-7, PS-16 dan ST-69 masih dijumpai fenokris yang cukup segar untuk dianalisis mikroprob. Conto batuan basalt menunjukkan kehadiran klinopiroksen berkomposisi salit sampai augit. Sedangkan klinopiroksen di dalam gabro (CD-7 dan PS-16) mempunyai komposisi berkisar antara Wo46-En42-Fs12 (PS-16) sampai Wo35En49Fs16 (CD-7) atau jenis endiopsid sampai augit. Evolusi kimiawi klinopiroksen dapat dianalisis dari hasil perajahan di dalam beberapa diagram sejumlah kation tertentu versus $\mathrm{FM}(\mathrm{Fe} / \mathrm{Fe}+\mathrm{Mg})$; lihat Gambar III.3 dan III.4. Klinopiroksen batuan diabas mempunyai variasi FM berkisar antara $0,07-0,27$, sedangkan gabro menunjukkan variasi FM antara 0,14 

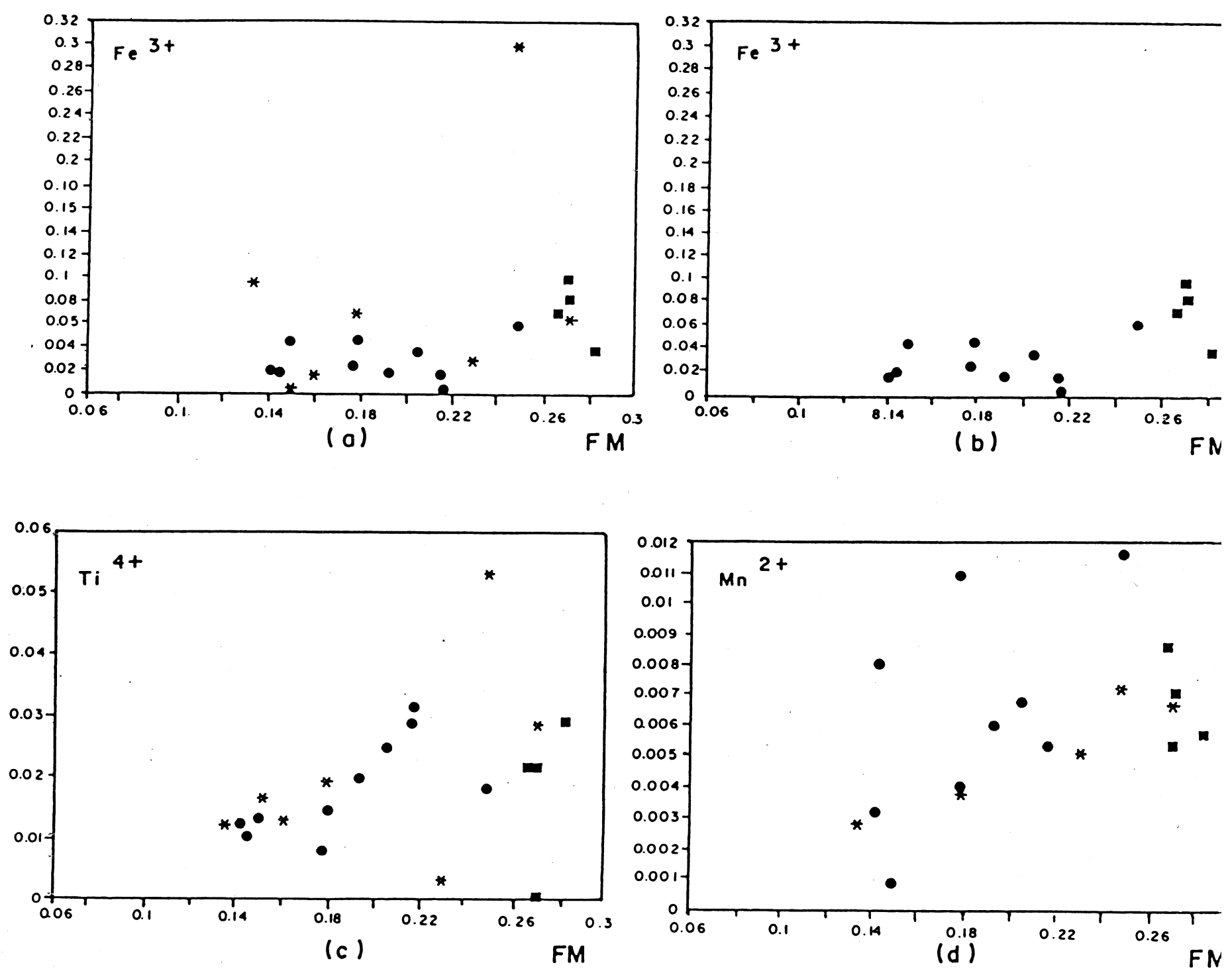

Gambar III.3. Diagram korelasi antara kation $\mathrm{Fe}^{3+}, \mathrm{Ti}^{4+}, \mathrm{Mn}^{2+}$ dengan $\mathrm{FM}$ dari mineral klinopiroksen : basalt $(\bullet)$, diabas $(*)$, gabro (๘). 

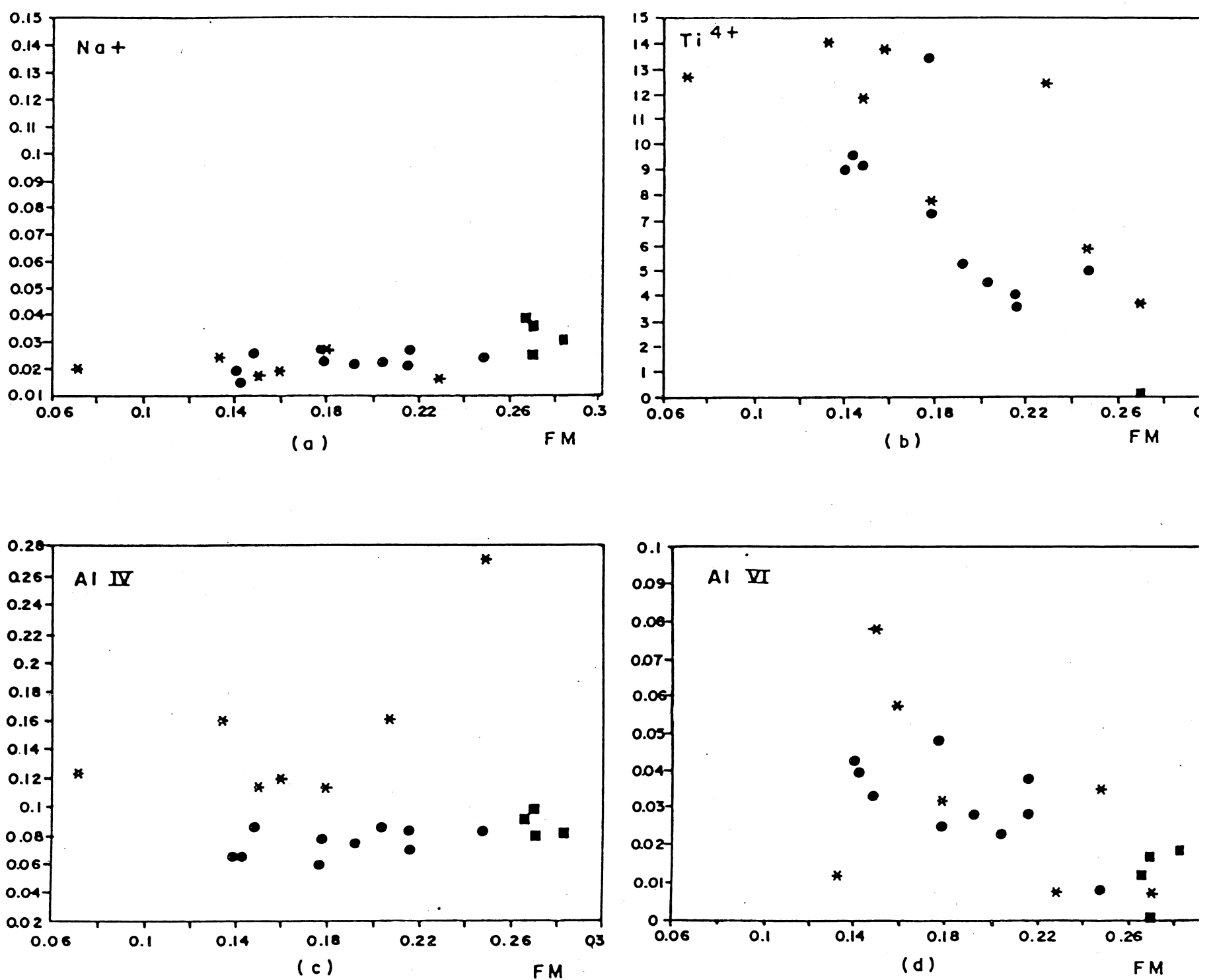

Gambar III.4. Diagram korelasi antara kation $\mathrm{Na}^{+}, \mathrm{Ti}^{4+}, \mathrm{Al}$ IV dan $\mathrm{Al}$ VI dengan FM dari mineral klinopiroksen : basalt $(\bullet)$, diabas $(*)$, gabro (-). 
- 0,28. Dari hasil perajahan di dalam diagram $\mathrm{Ti}^{4+}, \mathrm{Mn}^{2+}$, maupun $\mathrm{Fe}^{3+}$ versus FM menunjukkan adanya korelasi positif yang mana kenaikan unsur-unsur $\mathrm{Ti}^{4+}$, $\mathrm{Mn}^{2+}$, dan $\mathrm{Fe}^{3+}$ sesuai dengan kenaikan FM. Hubungan linier positif antara $\mathrm{Fe}^{3+}$ versus FM lebih jelas terlihat pada diagram III-3b dimana hanya satu gabro yang dirajah. Pola tersebut dapat ditafsirkan bahwa periode pembentukan kedua jenis gabro tersebut berbeda; kemungkinan gabro CD-7 terbentuk relatif kemudian. Hal ini diperkuat pula oleh kadar $\mathrm{SiO}_{2}$ yang lebih besar pada CD7 $(50,60 \%)$ daripada PS 16 yang mana kadar $\mathrm{SiO}_{2}$ nya sekitar 48,50\%. Sedangkan Al VI (Al koordinasi 6) serta Al IV dan Al/Ti semakin berkurang sejalan dengan diferensiasi; hal ini ditunjukkan dengan korelasi negatif di dalam diagram Al VI, Al/Ti versus FM. Unsur Al IV tidak menunjukkan pola distribusi yang teratur; sementara $\mathrm{Na}^{+}$ relatif konstan selama periode kristalisasi klinopiroksen. Perlu diingatkan kembali bahwa mineral klinopiroksen mempunyai formula struktur dibentuk oleh 6 oksigen dan 4 kation; secara teoritis terdiri dari 4 kutub yaitu $\mathrm{CaMgSi}_{2} \mathrm{O}_{6}$ (diopsid), $\mathrm{Mg}_{2} \mathrm{Si}_{2} \mathrm{O}_{6}$ (klino-enstatit), $\mathrm{CaFeSi}_{2} \mathrm{O}_{6}$ (hedenbergit), serta $\mathrm{Fe}_{2} \mathrm{SiO}_{6}$ (ferrosilit). Pada kenyataannya jarang terjadi keempat ikatan tersebut diisi oleh satu silika. Masuknya Al VI di dalam kisi tetrahedron (kisi Z) sebagai komplemen dari silika valensi empat mengakibatkan adanya ketidakseimbangan dalam struktur formulanya. Ketidakseimbangan ini dapat dikompensasi dengan adanya substitusi kation $\mathrm{Fe}^{3+}, \mathrm{Cr}^{3+}, \mathrm{Ti}^{4+}$, dan $\mathrm{Al}$ VI kedalam kisi oktahedron (kisi Y). Komponen yang mengandung substitusi keempat kation tersebut ini disebut non kuadrilateral karena komponen tersebut tidak termasuk ke dalam 4 kutub yang sudah disebutkan sebelumnya. Keempat kation $\mathrm{Fe}^{3+}, \mathrm{Cr}^{3+}, \mathrm{Ti}^{4+}$ serta $\mathrm{Al} \mathrm{VI}$ dapat masuk ke dalam kisi oktahedron dengan memperhatikan keseimbangan sebagai berikut :

$$
\mathrm{YAl}^{3+}+\mathrm{YFe}^{3+}+\mathrm{YCr}^{3+}+\mathrm{Y}_{2} \mathrm{Ti}^{4+}=\mathrm{Z} \mathrm{Al}^{3+}+\mathrm{XNa}^{+}
$$

Apabila hasil analisis klinopiroksen menunjukkan adanya Al IV dan Al VI, maka ada beberapa kemungkinan substitusi utama di dalam klinopiroksen sebagai berikut (Papike et.al., 1974, Cameron dan Papike 1980 dan 1981, dikutip dari 
Yuwono, 1987) :

1. Substitusi molekul Tschermark; terdiri dari empat macam yaitu :

$$
\begin{aligned}
& \mathrm{Al} \mathrm{IV} \text { - Al IV : Al - Tschermark } \\
& \mathrm{Ti}^{4+}-\mathrm{Al} \mathrm{IV}: \mathrm{Ti} \text { - Tschermark } \\
& \mathrm{Fe}^{3+} \text { - } \mathrm{Al} \mathrm{IV}: \text { Ferri - Tschermark } \\
& \mathrm{Cr}^{3+} \text { - } \mathrm{Al} \mathrm{IV}: \mathrm{Cr} \text { - Tschermark }
\end{aligned}
$$

2. Molekul soda terdiri dari :

$$
\begin{aligned}
& \mathrm{Na}^{+}-\mathrm{Fe}^{3+} \text { : akmit } \\
& \mathrm{Na}^{+}-\mathrm{Al} \mathrm{VI} \text { : jadeit }
\end{aligned}
$$

Perajahan di dalam beberapa diagram $\mathrm{Al} \mathrm{VI,} \mathrm{Ti}^{4+}, \mathrm{Fe}^{3+}$, serta $\mathrm{Cr}^{3+}$ versus Al IV klinopiroksen daerah penyelidikan menunjukkan adanya korelasi positif antara $\mathrm{Fe}^{3+}$ dan $\mathrm{Cr}^{3+}$ dengan $\mathrm{Al}$ IV. Ini berarti ada substitusi ferri-Tschermark dan Cr-Tschermark di dalam kristal klinopiroksen. Begitu pula substitusi akmitik terdapat pada klinopiroksen, ditunjukkan oleh grafik linier pada diagram $\mathrm{Na}^{+}$$\mathrm{Fe}^{3+}$ (Gambar III.5 dan III.6).

\section{Beberapa diagram diskriminasi geokimia.}

Komposisi dari klinopiroksen sangat bervariasi tergantung dari komposisi kimia batuan, misalnya saja mineral klinopiroksen dalam basalt alkali mempunyai kandungan $\mathrm{Al}$ dan Ti yang relatif lebih tinggi daripada di dalam basalt toleit dengan kandungan Si yang lebih rendah. Adanya hubungan yang erat antara komposisi klinopiroksen dan kimia batuan semakin diperjelas dengan semakin banyaknya penelitian yang memperbandingkan berbagai komposisi rata-rata klinopiroksen yang berasal dari tipe magma yang berbeda (antara lain Nisbet \& Pearce, 1977; Papike \& White, 1979; Leterrier et al., 1982). Pada pembahasan ini telah dipilih diagram-diagram yang dibuat oleh Leterrier dan kawan-kawan (1982), yang merupakan penyempurnaan dari diagram Nisbet \& Pearce (1977). Hasil perajahan di dalam diagram-diagram (secara berurutan) $\mathrm{Ti}-(\mathrm{Ca}+\mathrm{Na})(\mathrm{Ti}-\mathrm{Cr})-\mathrm{Ca}$, dapat disimpulkan bahwa sebagian besar dari klinopiroksen batuan basalt (fenokris) dan 

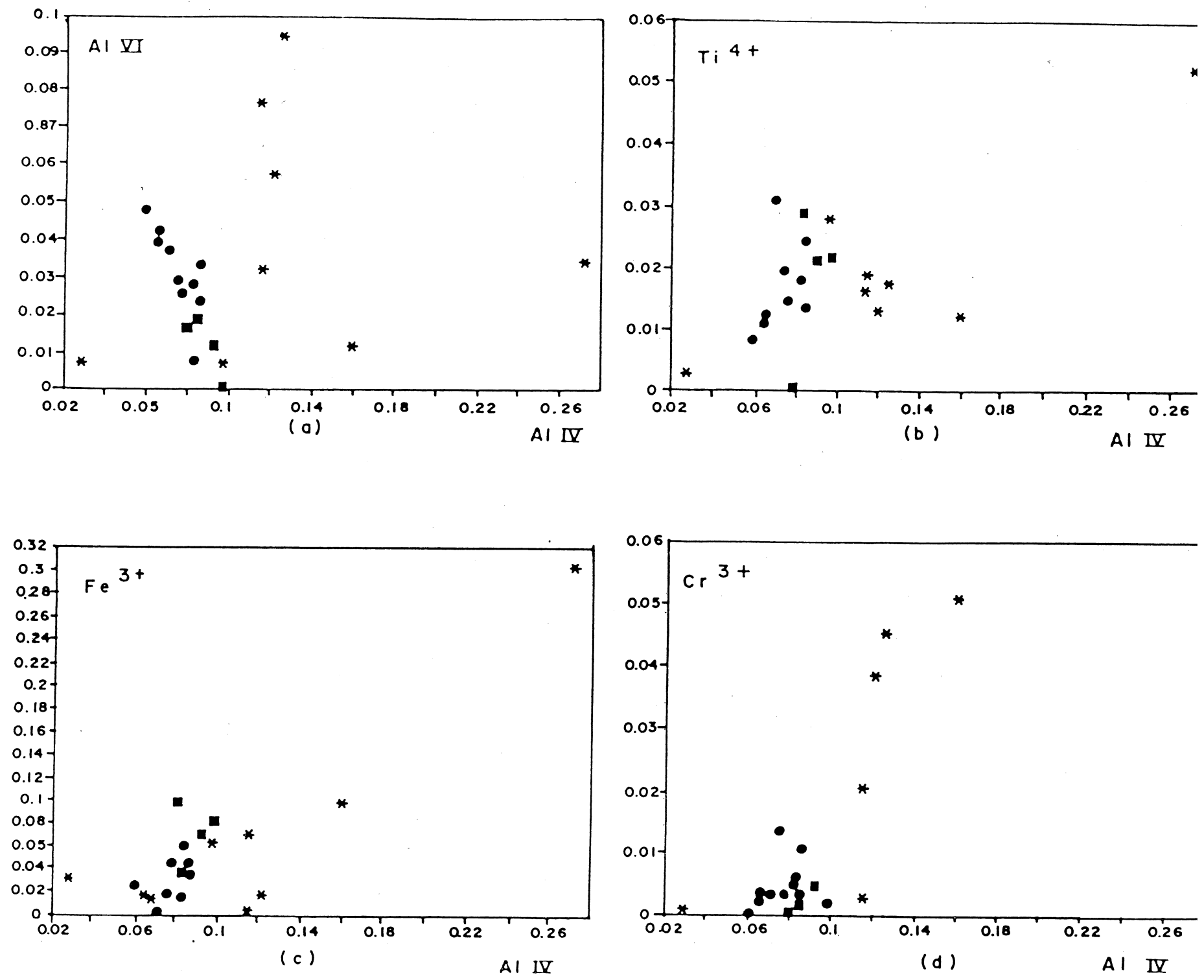

Gambar III.5. Diagram korelasi antara komponen-komponen non kuadrilateral dari klinopiroksen : basalt $(\bullet)$, diabas $(*)$, gabro $(\bullet)$. 

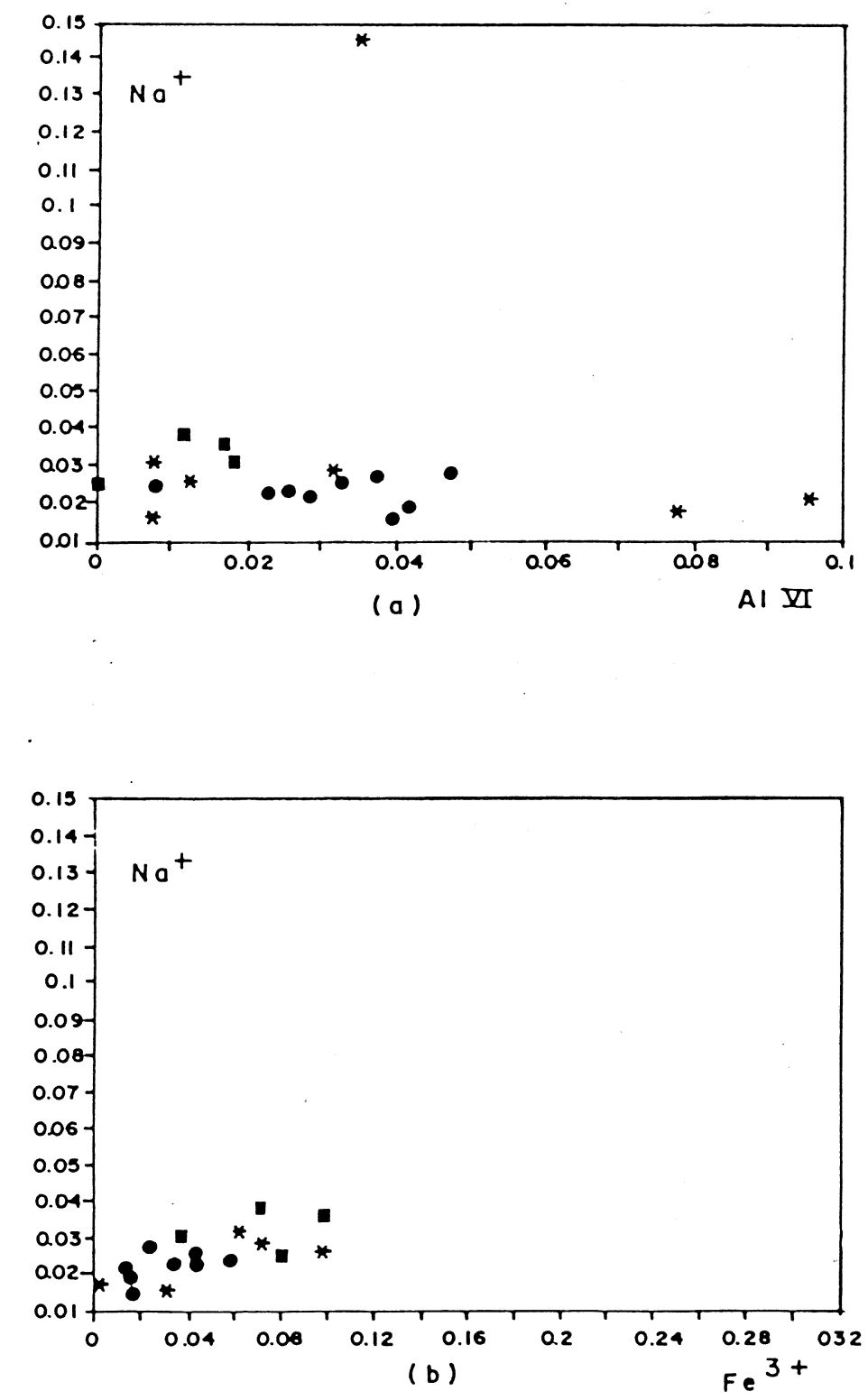

Gambar III.6. Diagram korelasi antara komponen-komponen non kuadrilateral dari klinopiroksen : basalt $(\bullet)$, diabas (*), gabro (•). 
gabro Karangsambung Utara mempunyai afinitas toleit, non-orogenik (Gambar III.7); berarti dapat terbentuk di lingkungan abisal, kepulauan samudera, daratan, cekungan busur belakang, atau basalt transisi pada lajur rekahan (rift zone). Hasil yang sama diperoleh dari perajahan di dalam diagram-diagram $\mathrm{Ti}-\mathrm{Ca}, \mathrm{Ti}-\mathrm{Na}$, $\mathrm{Al}$ IV - Ca, dan Cr - Ca (Gambar III.8).

\subsection{Kesimpulan}

Dari hasil analisis petrografi dan mineralogi himpunan batuan ultramafis (harsburgit terserpentinisasi, serpentinit, lersolit hornblenda), dan batuan mafis (gabro, diabas, serta basalt) di daerah Karangsambung Utara, dapat disimpulkan bahwa :

1. Komposisi batuan mafis yang dijumpai di daerah ini terdiri plagioklas, dan piroksen sebagai komponen utama; olivin tidak teramati pada batuan yang berbutir kasar maupun yang berbutir halus. Gabro, diabas, serta basalt yang tidak mengandung atau hanya mengandung sedikit olivin dan umumnya aphyric, dapat digolongkan kedalam jenis toleit.

2. Batuan ultramafis yang diketemukan di dalam komplek ofiolit di daerah penyelidikan pada umumnya bertekstur kumulat (kumulus); ini berarti pembentukannya dipengaruhi oleh pengendapan gravitasi dari magma primer, (Wager \& Brown, 1967; Thayer, 1960; Jackson, 1961; dikutip dari Nicolas, 1986).

3. Adanya variasi piroksen pada batuan kumulat (lersolit dan gabro) dan batuan volkanis (basalt dan diabas), dari bronsit/enstatit - endiopsid (augit-Mg), pada fase awal diferensiasi hingga hipersten (yang diduga merupakan inversi dari pigeonit) - augit pada fase akhir, menunjukkan bahwa kristalisasi terjadi pada kondisi yang cukup stabil untuk pembentukan piroksen-Mg dan piroksen yang lebih kaya akan besi. Sedangkan augit yang selalu hadir pada kedua kondisi tersebut, dianggap sebagai mineral yang exsolved pada temperatur subsolidus.

4. Hasil analisis mikroprob menunjukkan komposisi klinopiroksen batuan 

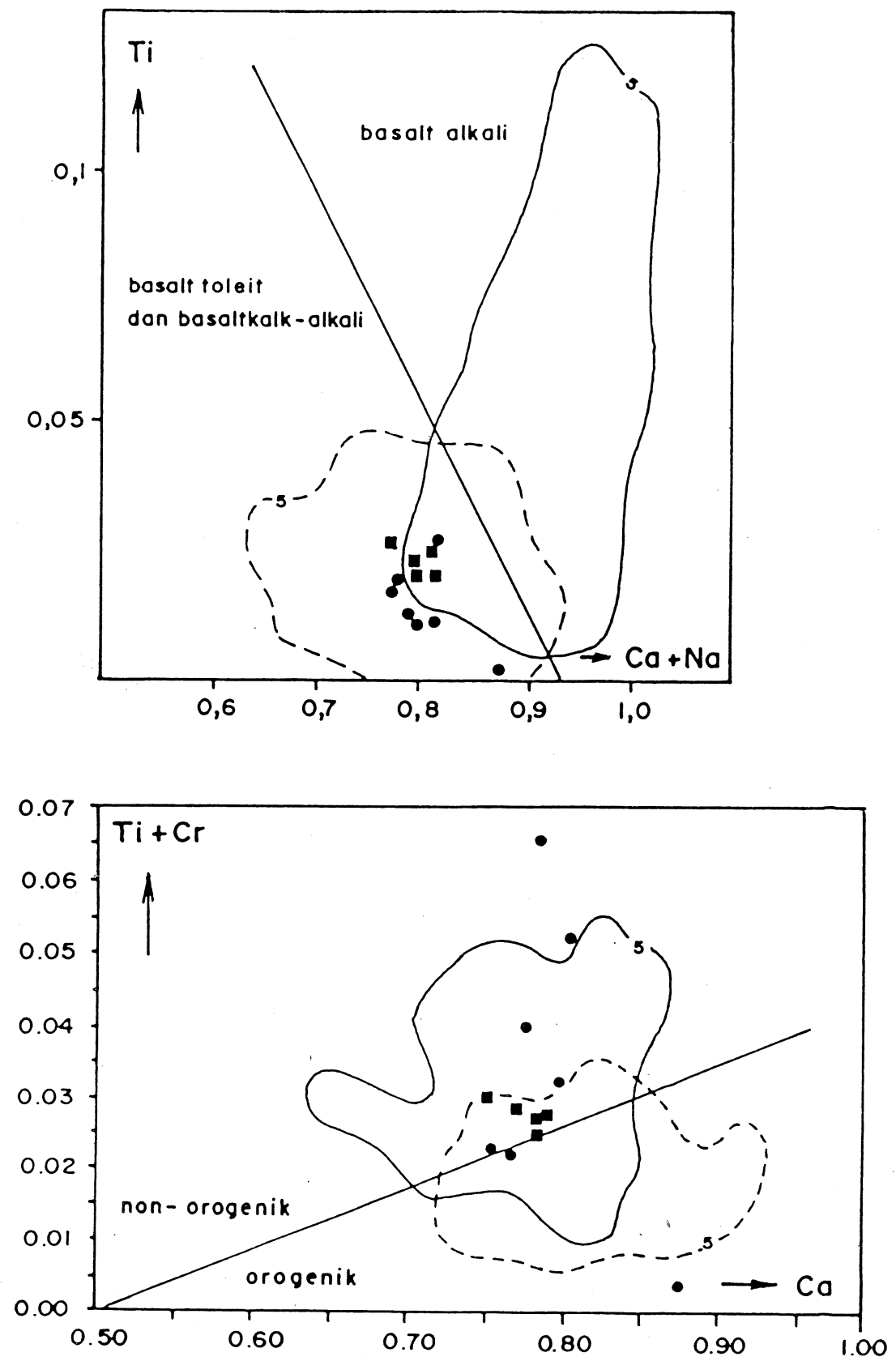

Gambar III.7a Perajahan komposisi klinopiroksen di dalam diagram Leterrier et $\& b$. al. (1982); basalt $(\bullet)$, gabro $(\bullet)$. 

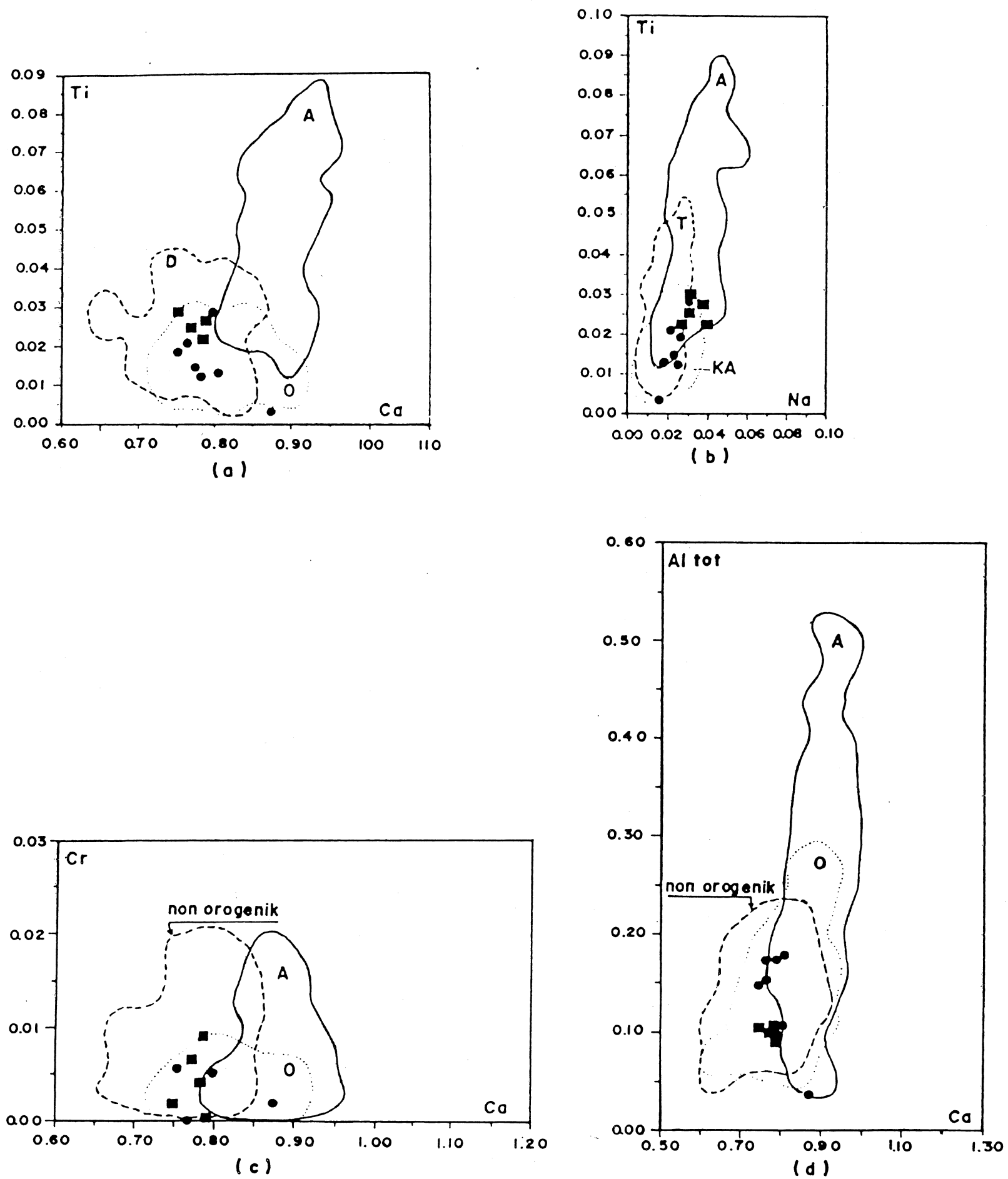

Gambar III.8. Distribusi mineral klinopiroksen di dalam diagram diskriminasi dari Leterrier et al (1982); basalt (•), gabro ( $\bullet), A=$ alkali, $\mathrm{O}=$ orogenik, $\mathrm{T}=$ toleit, $\mathrm{KA}=$ kalk alkali. 
gabro, diabas dan basalt bervariasi dari Wo45En46 Fs9 hingga Wo25En56 $\mathrm{Fs}_{11}$ atau dari jenis endiopsid hingga augit. Substitusi yang terdapat di dalam klinopiroksen mencakup $\mathrm{Fe}^{3+}$ - Tschermark, $\mathrm{Cr}^{3+}$ - Tschermark dan substitusi akmitik yang merupakan ciri dari batuan toleit. Hal ini diperkuat dengan hasil analisis diskriminasi geokimia mineral klinopiroksen yang menunjukkan batuan basalt, diabas dan gabro daerah berasal dari magma jenis toleit diduga terbentuk pada lingkungan non orogenik.

5. Mineral sekunder seperti serisit, lempung (smektit), klorit, serpentin, prehnit, amfibol sekunder (uralit, aktinolit, serta tremolit) kuarsa, karbonat, dan epidot selalu dijumpai pada semua batuan mafis ultramafis dengan proporsi jenis mineral yang berbeda. Hal ini menunjukkan bahwa batuanbatuan ini telah mengalami proses metamorfosis ganda derajat rendah yaitu fasies seolit (fasies laumontit-prehnit-kuarsa) dan fasies sekis hijau. Batuanbatuan ini kemudian mengalami proses deformasi ditandai dengan diketemukannya gejala-gejala struktur mortar, pemadaman bergelombang, hancuran (milonitisasi), serta retakan yang kadang-kadang terisi mineral sekunder. Kenampakkan demikian menunjukkan proses pengubahan serta deformasi pada batuan mafis-ultramafis tersebut terjadi pada waktu penempatan; apalagi kenyataan adanya tekstur batuan yang tetap meskipun telah mengalami rekristalisasi. Hal tersebut menunjukkan proses metamorfosis pada kondisi samudera (Miyashiro, 1973; Coleman, 1977) yang berarti dapat terjadi di lantai samudera ataupun di punggung tengah samudera (Miyashiro, 1974). 


\section{BAB IV}

\section{PETROLOGI DAN GEOKIMIA}

Sejumlah 25 conto batuan (mencakup 3 batuan serpentinit, 6 gabro, serta 16 batuan diabas dan basalt) dianalisis kimia untuk memperoleh data tentang pola unsur utama batuan serta beberapa unsur jejaknya. Duabelas conto batuan diantaranya 7 basalt dan diabas, sisanya gabro dianalisis untuk rare earth elements ( $R E E) ; 5$ conto batuan ( 2 serpentinit, 2 gabro, 1 basalt) dianalisis dengan metode mikroprob untuk klinopiroksen dan plagioklas. Untuk selanjutnya istilah rare earth elements (REE) diterjemahkan menjadi unsur tanah langka atau disingkat UTL. Hasil analisis kimia batuan secara keseluruhan dapat dilihat pada Tabel IV.1a, IV.1b, dan IV.2. Pada Tabel IV.1a dan IV.1b terlihat bahwa nilai hilang dibakar (H.D.) berkisar antara 1,5 - 5,5\% untuk batuan mafis, sedangkan batuan ultramafisnya (serpentinit / harsburgit terserpentinisasi) mencapai 14\%. Hal ini menunjukkan intensitas ubahan yang dialami conto batuan tersebut, antara lain pengubahan hidrotermal, metamorfosis, dan mungkin juga pengaruh pelapukan. Nilai H.D. yang tinggi pada batuan serpentinit adalah akibat dari penambahan gugusan - OH yang ditunjukkan oleh pembentukan serpentin (krisotil / antigorit) sebagai mineral hasil ubahan.

\subsection{Unsur utama dan unsur jejak}

Beberapa diagram dipilih untuk memperoleh gambaran tentang evolusi magma; antara lain diagram variasi unsur utama versus-ID (indek diferensiasi), diagram segitiga $\left(\mathrm{Na}_{2} \mathrm{O}+\mathrm{K}_{2} \mathrm{O}\right)-\mathrm{MgO}-\mathrm{FeO}^{*}(\mathrm{~A}-\mathrm{M}-\mathrm{F})$ serta diagram-diagram yang memperbandingkan kandungan $\mathrm{FeO}^{*}, \mathrm{TiO}_{2}, \mathrm{SiO}_{2}$, dan $\mathrm{Na}_{2} \mathrm{O}$, serta $\mathrm{K}_{2} \mathrm{O}$ terhadap $\mathrm{FeO}^{*} / \mathrm{MgO}$ (Miyashiro, 1974). Sedangkan untuk mempelajari diskriminasi geokimia dari batuan dipilih beberapa diagram dari Shervais (1982) yang menggunakan data nikel, krom, dan $\mathrm{TiO}_{2}$ yang dibandingkan dengan $\mathrm{FeO}^{*} / \mathrm{MgO}$. 


\subsubsection{Beberapa diagram evolusi magma}

Perajahan di dalam diagram variasi unsur utama dengan ID dapat dilihat pada Gambar IV.1a \& b. Hasil tersebut menunjukkan bahwa secara umum ofiolit di daerah Karangsambung Utara memperlihatkan urutan kristalisasi yang dimulai dengan pembentukan gabro pada indek diferensiasi (ID) sekitar 20, diikuti oleh diabas dan basalt pada indek diferensiasi mencapai 46. Tingginya nilai ID pada basalt dan diabas (pada umumnya ID basalt dan diabas tidak lebih dari 35) di daerah penyelidikan adalah akibat proses pengubahan yang terjadi seperti pembentukan kuarsa sekunder, gejala albitisasi yang tentunya akan meningkatkan kadar normatif kuarsa serta albit dan berakibat bertambahnya nilai ID. Pengaruh adanya proses pengubahan juga tercermin pada pola acak dari $\mathrm{SiO}_{2}$ maupun $\mathrm{Al}_{2} \mathrm{O}_{3}$; sedangkan besi $\left(\mathrm{FeO}^{*}\right)$ menunjukkan peningkatan sesuai dengan kenaikan indek diferensiasi. Kandungan $\mathrm{MgO}$ dan juga $\mathrm{CaO}$ relatif menurun selama periode diferensiasi, meskipun pada beberapa conto batuan basalt nampak tidak teratur. Unsur alkali seperti $\mathrm{Na}_{2} \mathrm{O}$ serta $\mathrm{K}_{2} \mathrm{O}$ cenderung untuk bertambah pada peroide kristalisasi yang lebih lanjut; terutama pada $\mathrm{K}_{2} \mathrm{O}$ terlihat peningkatan kadar yang cukup tajam meskipun beberapa conto batuan menunjukkan penyebaran $\mathrm{K}_{2} \mathrm{O}$ yang tidak beraturan. Hal ini dapat ditafsirkan sebagai akibat proses sekunder (pengubahan) yang lebih meningkatkan kadar-kadar alkali di dalam batuan (lihat Tabel IV.3). Pola $\mathrm{P}_{2} \mathrm{O}_{5}$ menunjukkan korelasi positif dengan ID, sedangkan $\mathrm{TiO}_{2}$ tidak memperlihatkan pola yang teratur. Adanya kenaikan kadar besi selama diferensiasi dari batuan-batuan ini juga teramati pada diagram A-M-F (Gambar IV.2) dimana pada fase pertengahan hingga akhir diferensiasinya menunjukkan peningkatan kadar besi; pola diferensiasi demikian merupakan ciri khas bagi magma toleit.

Evolusi dari magma toleit lebih lanjut dapat dipelajari dengan diagramdiagram dari Miyashiro \& Shido (1975) yang menggunakan $\mathrm{FeO}^{*} / \mathrm{MgO}$ diperbandingkan dengan $\mathrm{FeO}^{*}$ dan $\mathrm{TiO}_{2}$ (Gambar IV.3 a dan b). Pada diagram FeO * $\mathrm{FeO}^{*} / \mathrm{MgO}$ dan juga $\mathrm{TiO}_{2}-\mathrm{FeO}^{*} / \mathrm{MgO}$ teramati adanya kenaikan kadar $\mathrm{FeO}^{*}$ 


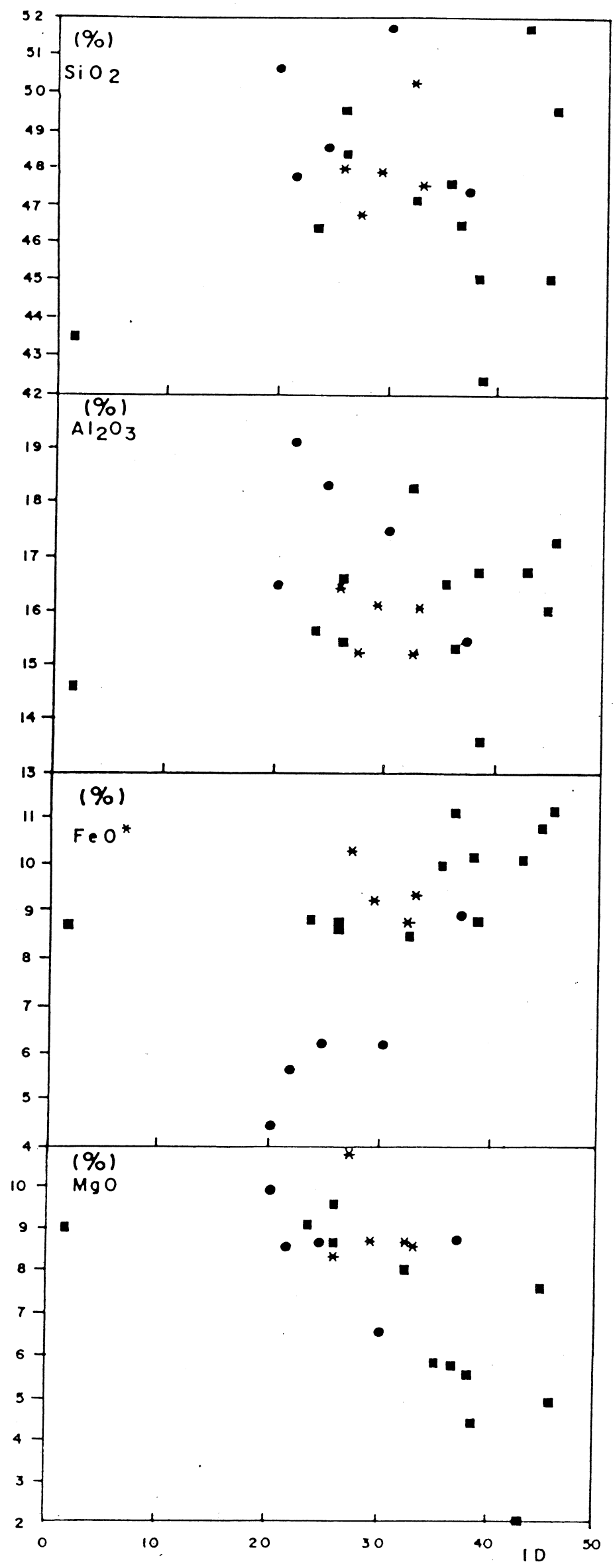

Gambar IV.1a. Diagram variasi Oksida sebagai fungsi dari ID (indeks diferensiasi); gabro $(\bullet)$, diabas $(*)$ dan basalt $(\boldsymbol{*})$ 


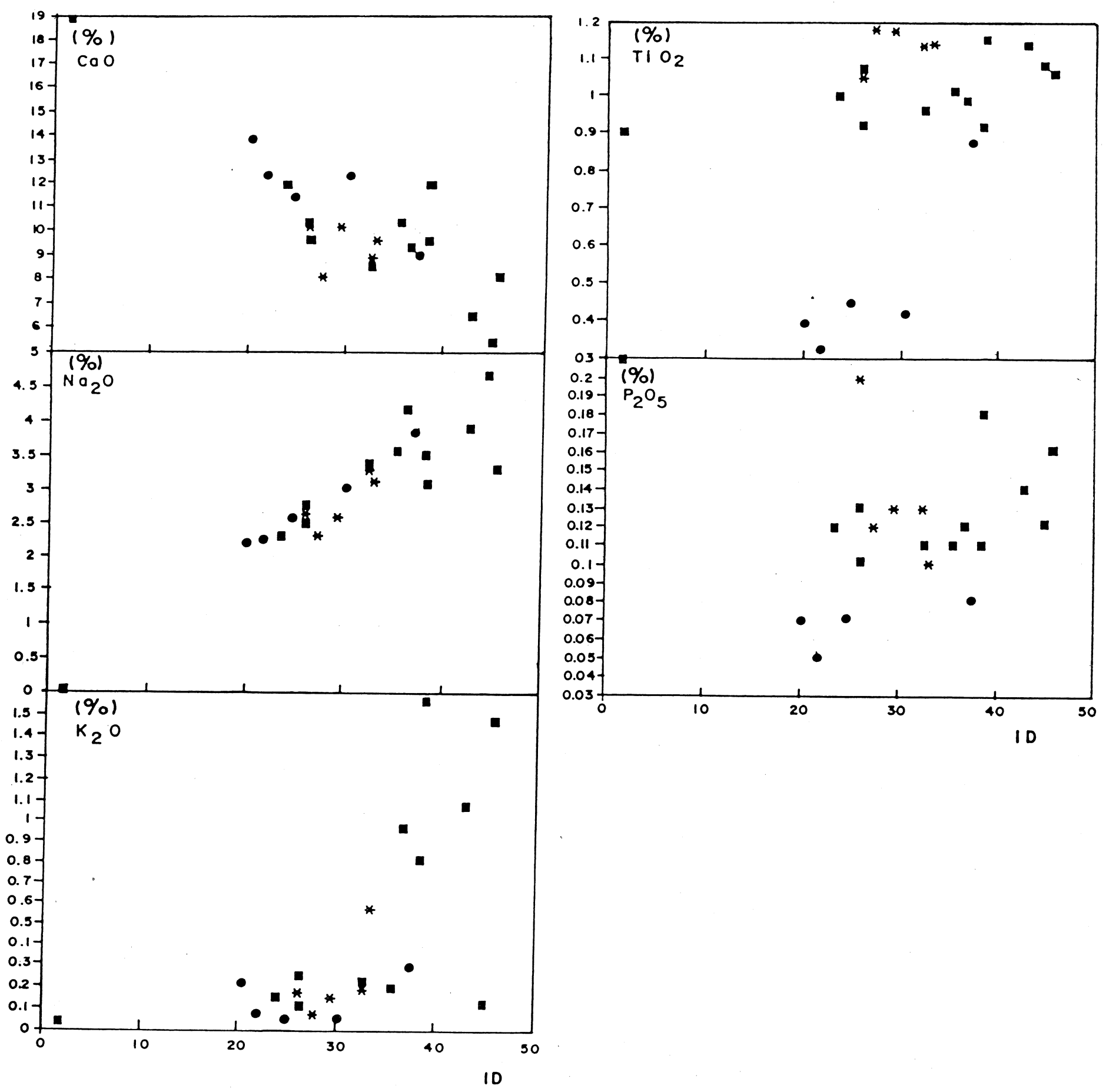

Gambar IV.1b. Diagram variasi Oksida sebagai fungsi dari ID (indeks diferensiasi); gabro $(\bullet)$, diabas $(*)$ dan basalt $(\bullet)$ 


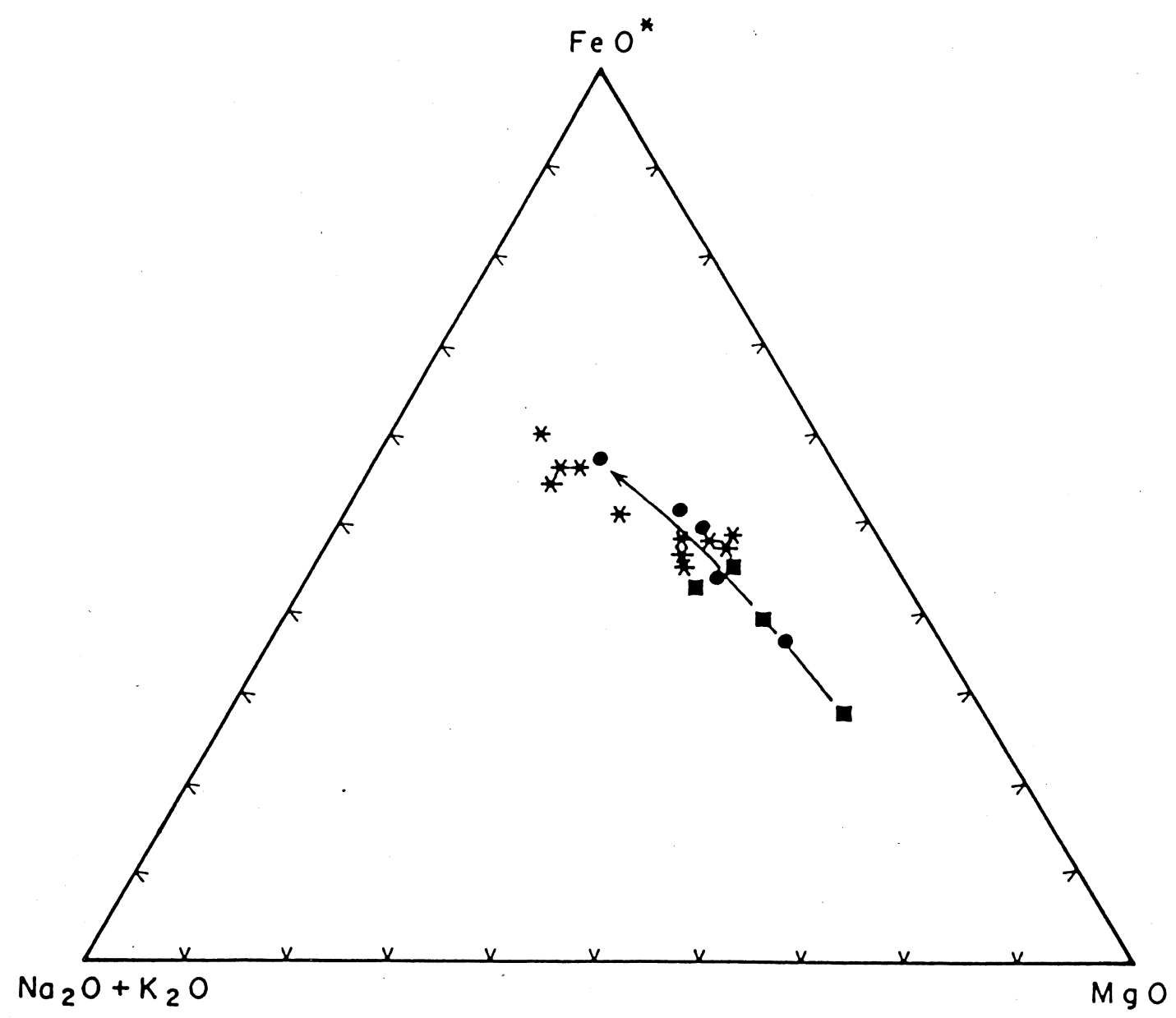

Gambar IV.2. Perajahan himpunan batuan ofiolit Karangsambung Utara di

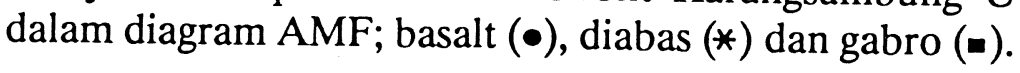



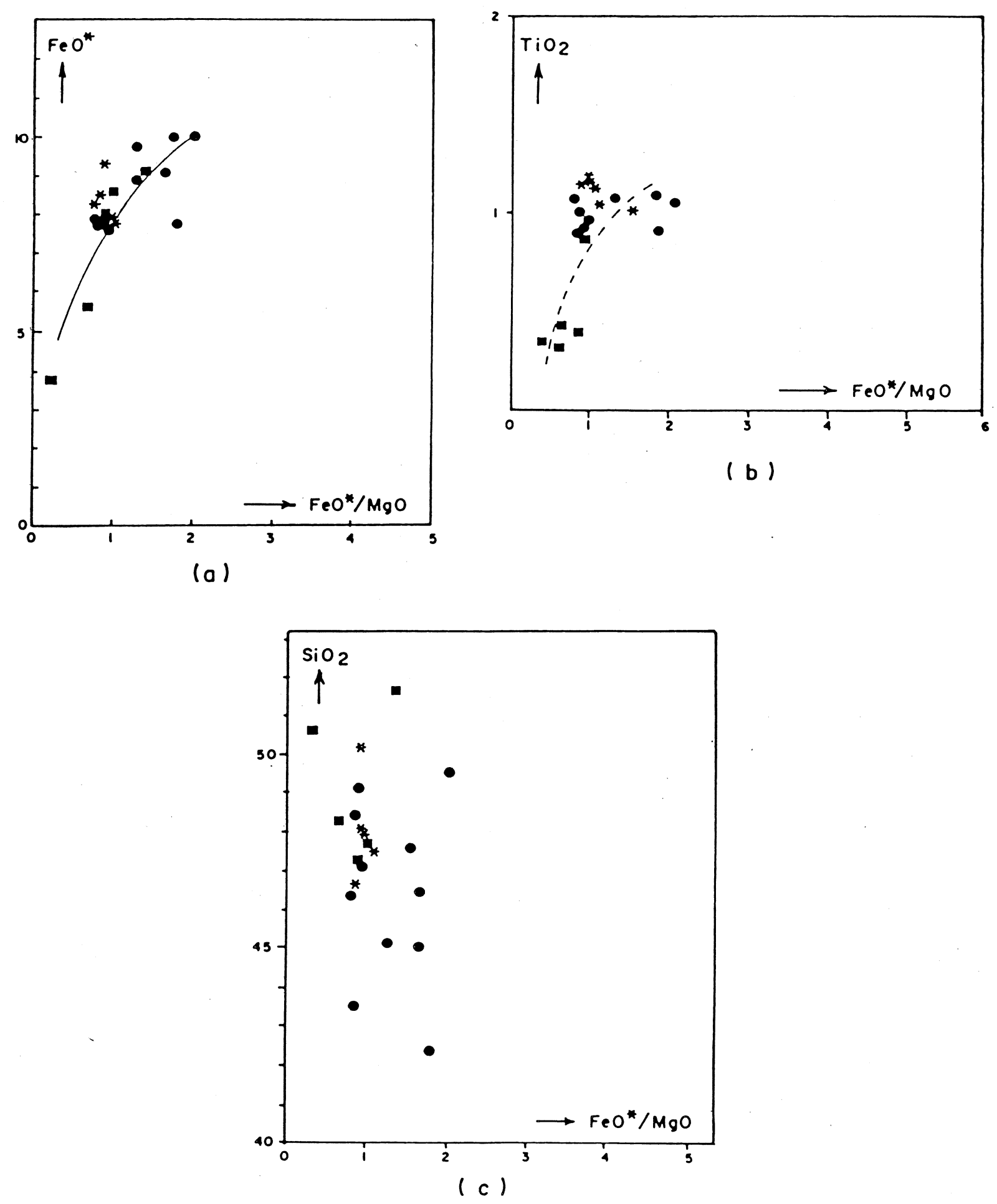

Gambar IV.3. Distribusi himpunan; basalt $(\bullet)$, diabas (*), gabro (•) di dalam diagram $\mathrm{FeO}$, $\mathrm{TiO}_{2}, \mathrm{SiO}_{2}$ versus $\mathrm{FeO}^{*} / \mathrm{MgO}$. 
maupun $\mathrm{TiO}_{2}$ berbareng dengan peningkatan $\mathrm{FeO}^{*} / \mathrm{MgO}$, yang merupakan salah satu karakteristik dari pola diferensiasi magma toleit. Kenampakan tersebut merefleksikan peranan penting dari kristalisasi olivin atau ortopiroksen yang kaya akan magnesium serta plagioklas pada awal kristalisasinya dalam pembentukan batuan kumulat; pola yang sama juga teramati pada batuan-batuan yang berasal dari bagian atas mantel.

Ciri-ciri kimia batuan lainnya ditunjukkan pada hasil perajahan di dalam diagram $\mathrm{SiO}_{2}-\mathrm{FeO}^{*} / \mathrm{MgO}$ (Gambar IV.3c). Pada gambar tersebut terlihat variasi jumlah $\mathrm{SiO}_{2}$ yang relatif tidak besar (berkisar dari $42-52 \%$ ) dan perbandingan $\mathrm{FeO}^{*} / \mathrm{MgO}$ yang kecil (kebanyakan antara $1-2$ ); hal tersebut menunjukkan fase awal diferensiasi magma. Umumnya batuan volkanis dari busur kepulauan atau dari kerangka tektonik lainnya dicirikan oleh variasi $\mathrm{SiO}_{2}$ yang lebih luas dengan perbandingan $\mathrm{FeO}^{*} / \mathrm{MgO}$ yang lebih besar. Meskipun demikian ada juga beberapa batuan volkanis toleit misalnya pada East Pasific Rise yang memperlihatkan variasi $\mathrm{SiO}_{2}$ cukup besar menunjukkan fase akhir dari diferensiasi magma.

Metode lain yang digunakan untuk mempelajari evolusi magma berikut genesis dari ofiolit adalah dengan menggunakan unsur jejak sebagai parameter antara lain nikel $(\mathrm{Ni})$ dan krom $(\mathrm{Cr})$. Dengan membandingkan $\mathrm{Ni}, \mathrm{Cr}$ dengan $\mathrm{FeO}^{*} / \mathrm{MgO}$ dapat diperoleh hasil seperti terlihat pada Gambar IV.4 a dan b. Pada kedua gambar tersebut terlihat kurva yang menunjukkan penurunan relatif cepat baik dari Ni maupun $\mathrm{Cr}$ pada waktu diferensiasi; hal ini menggambarkan pentingnya kristalisasi olivin dan klinopiroksen pada fase awal di dalam evolusi batuan volkanis. Hal ini diperkuat oleh hasil analisis petrografi dari gabro yang menunjukkan kehadiran mineral endiopsid sebagai klinopiroksen pertama yang terbentuk; olivin tidak muncul di dalam evolusi batuan volkanis, dan kedudukannya digantikan oleh ortopiroksen yang kaya akan magnesium (enstatit).

\subsubsection{Beberapa diagram diskriminasi geokimia}

Pola petrologi dan geokimia yang khas dari batuan volkanis secara langsung ada kaitannya dengan lingkungan tektonik dimana himpunan batuan tersebut 

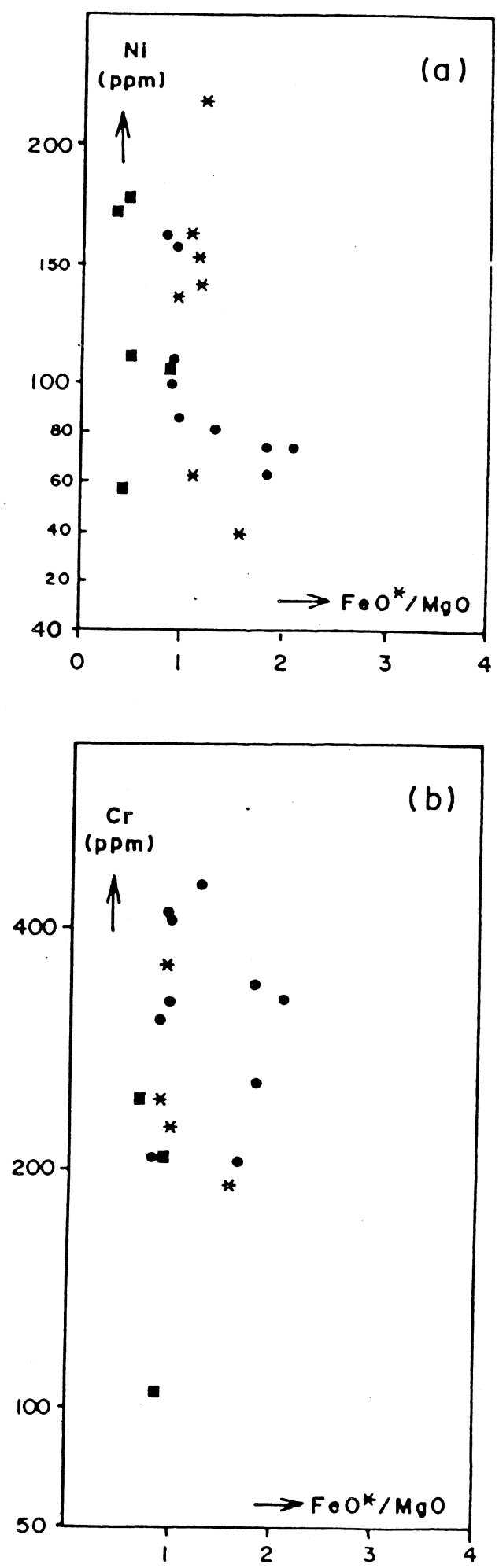

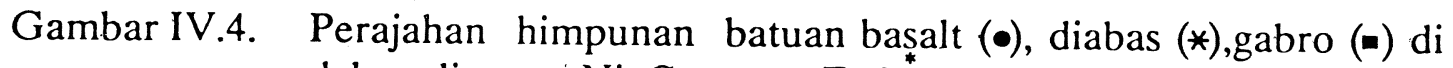
dalam diagram $\mathrm{Ni}, \mathrm{Cr}$ versus $\mathrm{FeO}^{*} / \mathrm{MgO}$. 
terbentuk (Jakes \& White, 1972; Pearce \& Cann, 1973; Pearce, 1976; Pearce \& Flower, 1977) meskipun dalam kenyataannya proses pengubahan seperti proses hidrotermal dan metamorfosis dapat mengaburkan pola asli dari susunan mineral dan geokimia batuan. Untuk menghindari hal ini di dalam penafsiran genesis dari batuan pada umumnya, maka dipilih diagram geokimia yang menggunakan unsur-unsur yang relatif tidak mobil seperti Ti, V, Cr, Ni, Y, Sr dan unsur tanah langka (UTL) dari kelompok lantanid (La, Ce, Nd, Sm, Eu, Gd, Dy, Er, Yb dan $\mathrm{Lu})$.

Pada Gambar IV.5a dan b dapat dilihat distribusi himpunan batuan ofiolit Karangsambung Utara di dalam diagram $\mathrm{SiO}_{2}-\mathrm{FeO}^{*} / \mathrm{MgO}$ dan $\mathrm{FeO}^{*}-\mathrm{FeO}^{*} /$ $\mathrm{MgO}$; di dalam kedua diagram tersebut batuan-batuan gabro, diabas, dan basalt tergolong ke dalam toleit; meskipun ada beberapa yang terletak di daerah kalk alkali. Hal ini mungkin akibat dari unsur-unsur besi dan silika yang relatif peka terhadap proses pengubahan.

Dari perajahan di dalam diagram semi logaritme dari Miyashiro \& Shido (1975) yang menggunakan unsur-unsur jejak seperti Ni, Cr, dan Ti (titanium) yang relatif tidak mobil (immobile) dan unsur-unsur yang agak mobil seperti besi dan magnesium, diperoleh hasil yang terlihat pada Gambar IV.6 dan IV.7. Sebagian besar dari batuan-batuan di dalam komplek ofiolit terletak di dalam daerah toleit samudera (oceanic tholeiite atau toleit abisal), yang dicirikan oleh kadar $\mathrm{Ni}, \mathrm{Cr}$, serta Ti yang relatif lebih tinggi jika dibandingkan dengan batuan kalk alkali. Ciri-ciri kimia lainnya adalah perbandingan antara $\mathrm{V}$ (vanadium) terhadap Ti/1000 yang berkisar antara 20 - 50 (Gambar IV.8); variasi nilai perbandingan tersebut menunjukkan kelompok batuan volkanis yang berasal dari punggung tengah samudera (Shervais, 1982). Ciri yang sama dimiliki oleh batuan volkanis yang berasal dari benua (continental flood basalt) tetapi memiliki kadar vanadium dan titanium relatif lebih besar dibandingkan dengan batuan yang berasal dari punggung tengah samudera (V sekitar 250 - 500 ppm dan Ti bervariasi dari 10.000 $-16.000 \mathrm{ppm})$. 

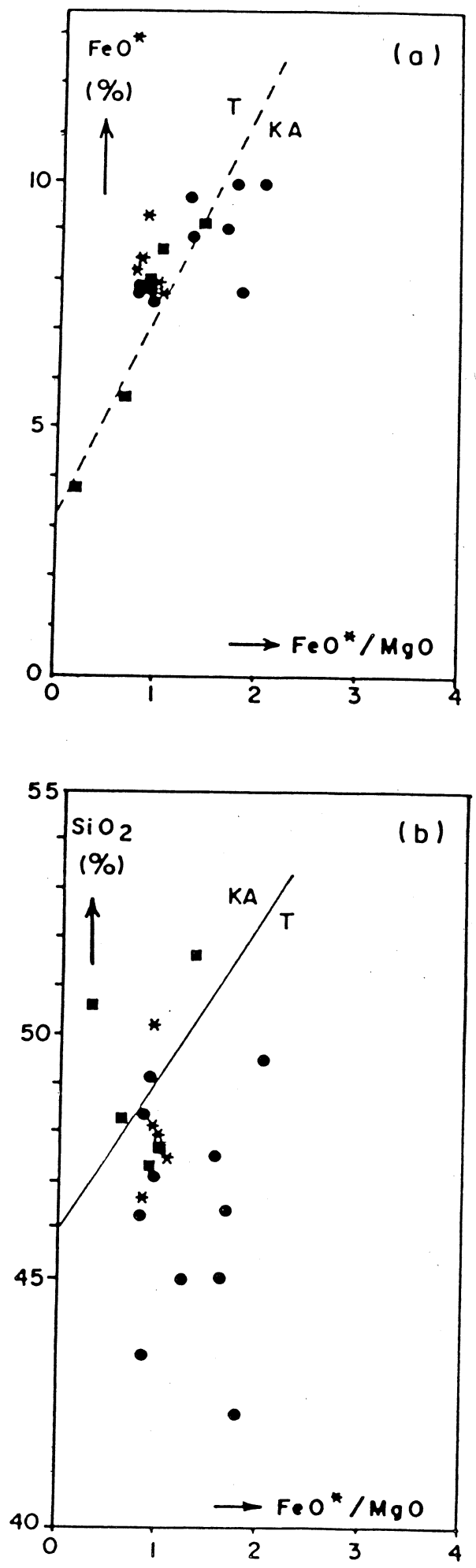

Gambar IV.5. Distribusi himpunan batuan; basalt (o), diabas (*), gabro (*) daerah Karangsambung Utara di dalam diagram Miyashiro \& Shido (1975). 

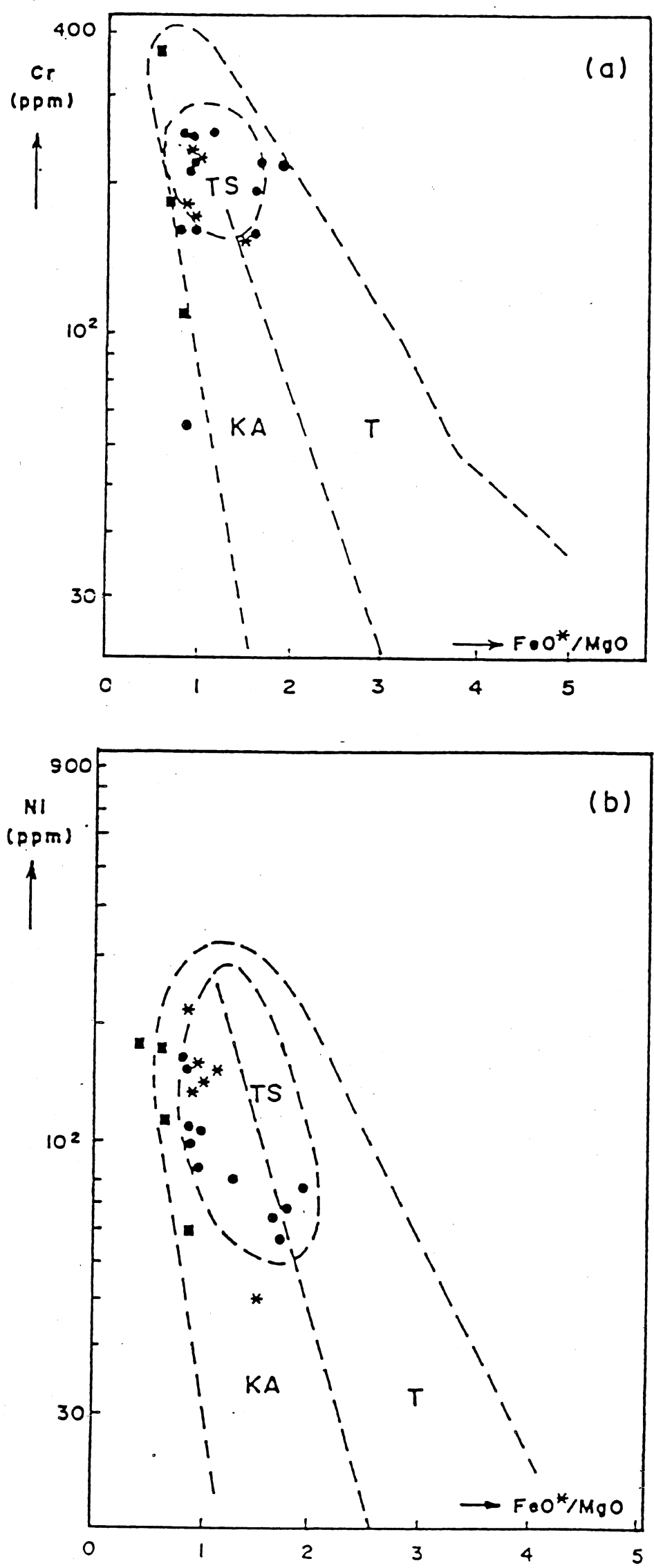

Gambar IV.6. Distribusi basalt $(\bullet)$, diabas (*), gabro (•), daerah penyelidikan di dalam diagram Miyashiro \& Shido (1975). 


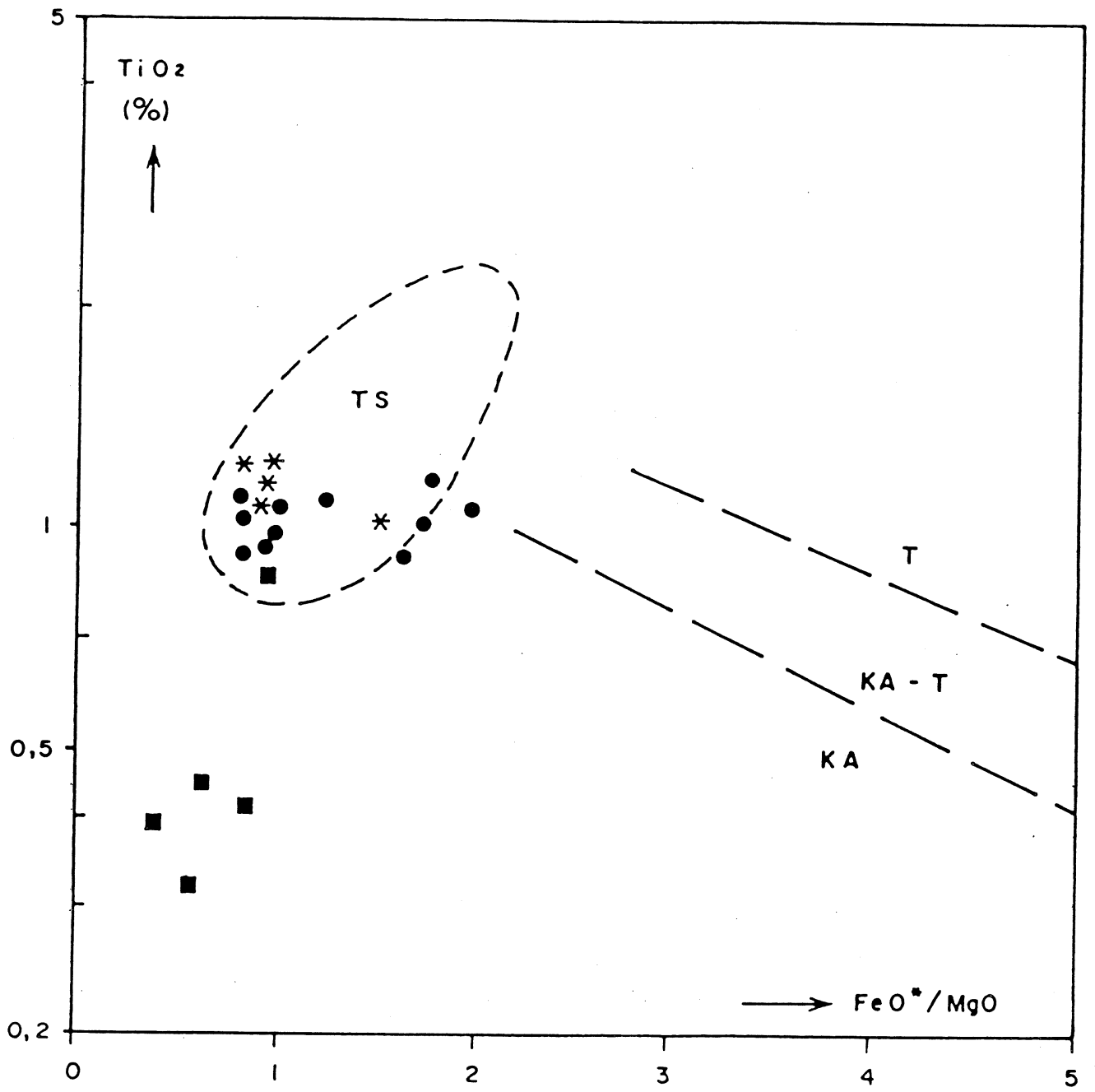

Gambar IV.7. Distribusi batuan; basalt (•), diabas (*), gabro (•), daerah Karangsambung Utara di dalam diagram $\mathrm{TiO}_{2}-\mathrm{FeO}^{*} / \mathrm{MgO}$. 


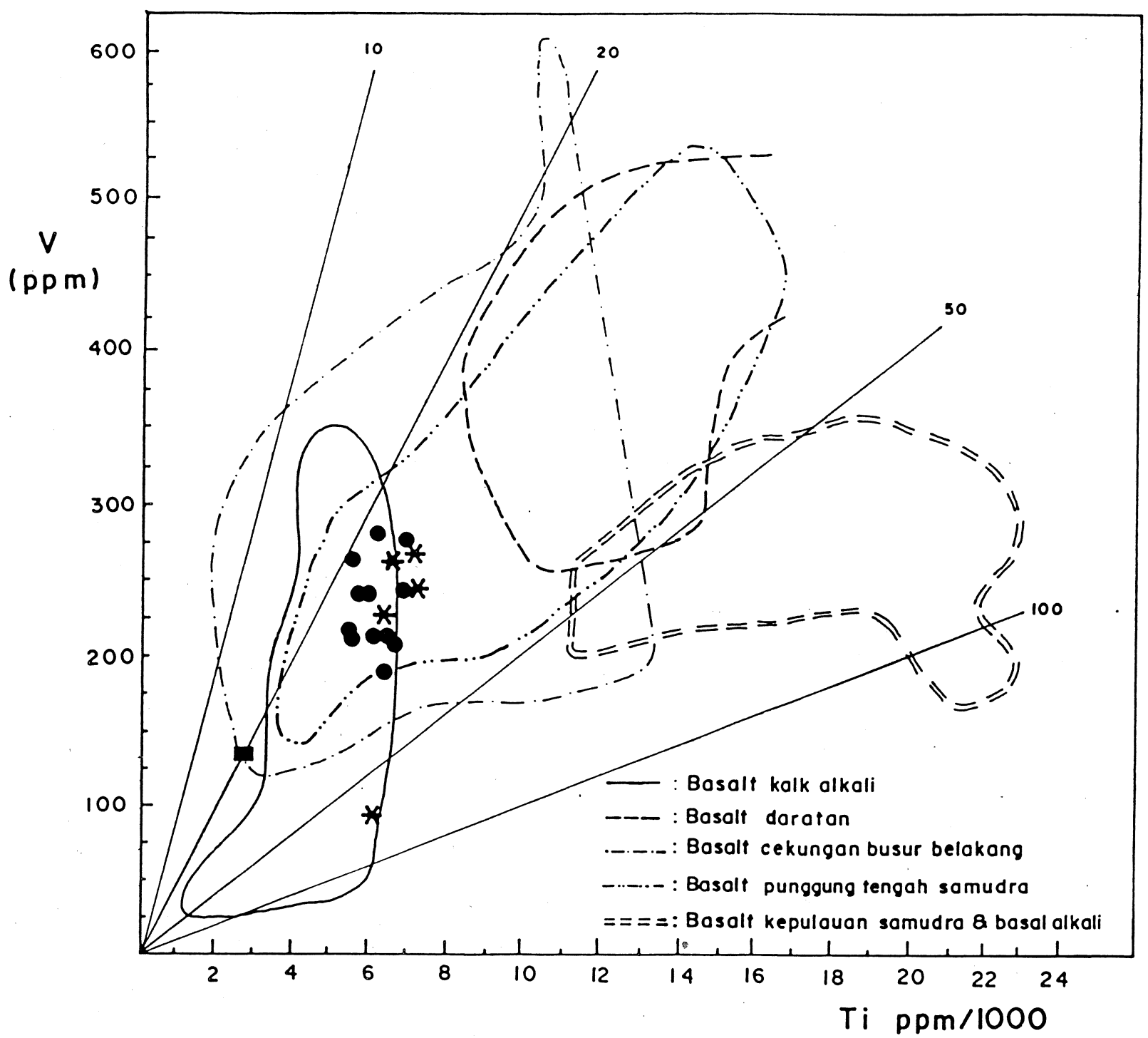

Gambar IV.8. Distribusi himpunan batuan; basalt (•), diabas (*), gabro ( daerah Karangsambung Utara di dalam diagram V - Ti/1000 (Shervais, 1982). 


\subsection{Unsur tanah langka}

Salah satu masalah yang harus dipecahkan di dalam permasalahan ofiolit adalah tentang hubungan genetis antar batuan yang tercakup dalam komplek ofiolit tersebut. Untuk maksud tersebut dapat dipergunakan unsur jejak yang relatif tahan terhadap proses pengubahan sebagai parameter, yaitu unsur tanah langka, dan unsur magmaphile (Treuil \& Joron, 1975). Unsur tanah langka (UTL) mencakup unsur La (latanum) hingga Lu (lutesium) dengan nomer atom 57-71 tergolong ke dalam grup IIIA pada tabel sistem periodik yang mempunyai kesamaan dalam sifat fisik dan kimia. Kesamaan ini terjadi karena konfigurasi elektron unsur-unsur tersebut menunjukkan tingkat oksidasi $3^{+}$dan secara tetap menunjukkan penurunan yang relatif kecil dari jari-jari ionnya sesuai dengan kenaikan atomnya untuk suatu nomer koordinasi tertentu. Meskipun mempunyai sifat kimia yang sama, UTL tersebut satu terhadap lainnya dapat mengalami fraksinasi sebagian oleh proses-proses petrologi maupun mineralogi. Berbagai macam jenis dan ukuran dari kation di dalam mineral pembentuk batuan memungkinkan terjadinya fraksinasi kimia tersebut. Hal ini merupakan proses yang penting di dalam geokimia. Perlu diterangkan di sini bahwa beberapa peneliti kadang-kadang memasukkan juga unsur yttrium ( $\mathrm{Y}$ dengan nomor atom 39) yang juga termasuk dalam golongan III A, sebagai salah satu anggota UTL karena mempunyai kesamaan dalam sifat kimianya dengan UTL lainnya. Besarnya minat di dalam studi di bidang geokimia UTL makin bertambah akibat adanya kenyataan bahwa penentuan tingkat fraksinasi UTL di dalam batuan maupun mineral dapat digunakan sebagai parameter genesis batuan maupun mineral dan juga karena semakin mudahnya untuk melakukan analisis kuantitatif dari unsur-unsur tersebut secara akurat meskipun kadarnya sangat rendah. Penggunaan data kelimpahan (abundance) UTL dalam kaitan dengan masalah petrogenesis lebih banyak terpusat pada evolusi batuan volkanis yang antara lain terdiri dari proses-proses seperti pelelehan sebagian (partial melting) dari bahan kerak dan mantel, kristalisasi fraksional dan atau percampuran magma. 
Membandingkan kelimpahan UTL yang dihitung dengan yang diperoleh dari model petrogenesis secara teoritis akan banyak membantu membatasi kemungkinan hipotesa dari genesis himpunan batuan ataupun himpunan mineral.

\subsubsection{Normalisasi kondrit}

Terhadap tujuhbelas conto batuan ( 7 basalt, 5 diabas serta 5 gabro) dari daerah penyelidikan telah dilakukan analisis UTL dengan metode pengenceran isotop (isotope dilution) untuk preparasi conto yang kemudian dianalisis dengan spektrometer masa. Unsur-unsur yang dianalisis mencakup $\mathrm{La}, \mathrm{Ce}, \mathrm{Nd}, \mathrm{Sm}, \mathrm{Eu}$, Gd, Dy, Er, Yb, dan Lu. Pada Tabel IV.2 terlihat bahwa hasil analisis UTL menunjukkan kelimpahan dalam unsur dengan nomor atom genap seperti $\mathrm{Ce}, \mathrm{Nd}$, Sm, Gd, Dy, Er, serta Yb selalu lebih besar daripada kelimpahan unsur dengan nomor atom ganjil. Kesimpulan tersebut sesuai dengan stabilitas dari inti atom dimana inti dengan $\mathrm{N}$ (netron) dan $\mathrm{Z}$ (proton) yang masing-masing jumlahnya genap adalah paling stabil; sedangkan untuk $\mathrm{N}$ dan $\mathrm{Z}$ yang masing-masing jumlahnya ganjil inti atomnya akan paling tidak stabil. Karena stabilitas inti berhubungan langsung dengan kelimpahan, maka kandungan suatu unsur yang tinggi sekali di alam, menunjukkan inti atomnya stabil. Ini berarti juga bahwa unsur. yang stabil dalam UTL adalah unsur yang inti atomnya mempunyai jumlah $\mathrm{N}$ dan $\mathrm{Z}$ masing-masing genap. Kesimpulan ini sesuai dengan pendapat peneliti terdahulu seperti yang dikemukakan oleh Henderson (1984) dan Haskin (1984); lihat Gambar IV.9a, b dan c.

Pola yang dihasilkan dari perajahan kelimpahan UTL dari beberapa conto batuan mafis di daerah penyelidikan (Gambar IV.9a) memperlihatkan adanya kesamaan dalam pola grafiknya dengan grafik yang dihasilkan dari perajahan UTL suatu sistim solar (Henderson, 1984) pada Gambar IV.9b; kesamaan tersebut juga terlihat pada grafik Gambar IV.9c, yang merupakan hasil perajahan kelimpahan UTL dari basalt yang hipotetis menurut Haskin (1984). Untuk menghilangkan adanya variasi kelimpahan yang mencolok tersebut sehingga gambaran yang diperoleh lebih jelas maka data kelimpahan UTL yang diperoleh dari hasil analisis 

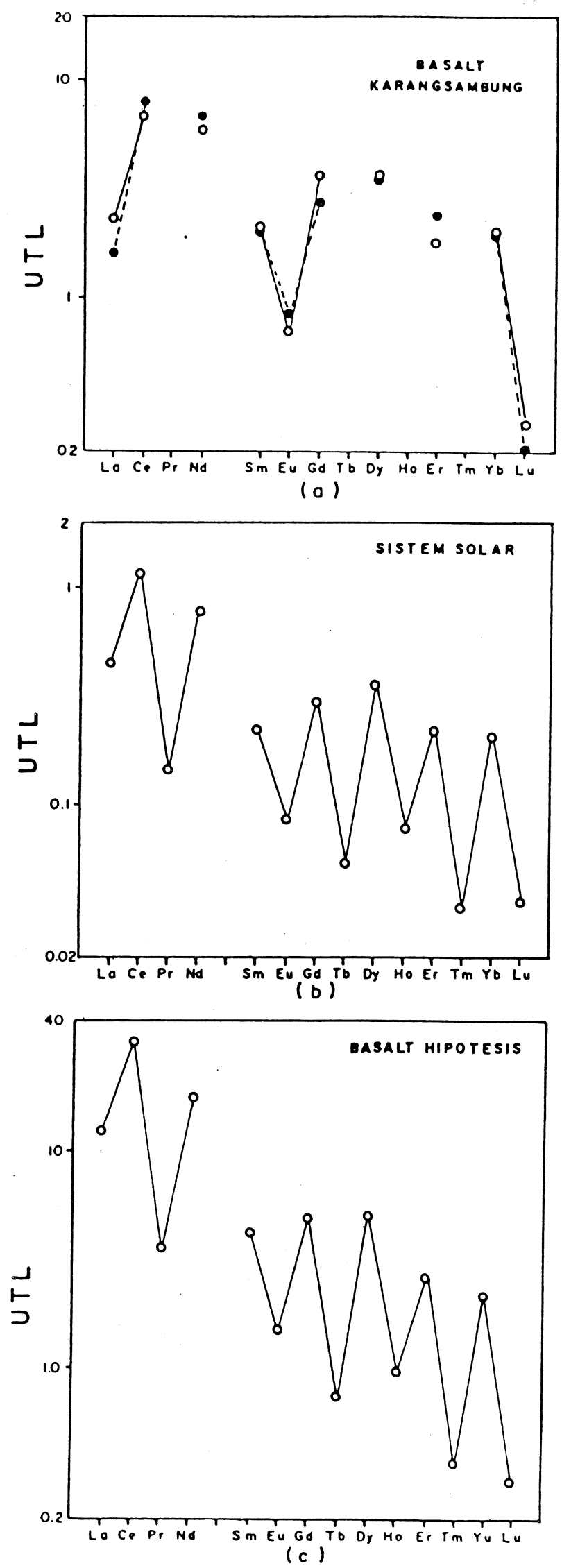

Gambar IV.9. Perajahan kelimpahan UTL di bandingkan dengan nomor atom; a:UTL basalt daerah penyelidikan, b: UTL dari sistem solar (Cameron, 1973), c: UTL basalt hipotesis dari Haskin, 1984. 
tersebut perlu dinormalisasi dengan data kelimpahan UTL sejenis dari suatu bahan yang dipilih sebagai standar pembanding. Normalisasi dilakukan dengan membagi setiap konsentrasi UTL dengan konsentrasi UTL sejenis dari bahan pembanding. Data tersebut kemudian dirajah di dalam diagram semi logaritme dengan nomor atom sebagai absisnya.

Sebagai conto cara menormalisasi data kelimpahan UTL dapat dilihat pada Gambar IV.10 di mana telah dipilih metode normalisasi dengan kondrit tipe carbonaceous chondrite sebagai bahan pembanding. Data kelimpahan UTL kondrit diperoleh dari Sun et al. (1979) yang tercantum pada Tabel IV.2. Gambar IV.10a bagian bawah memperlihatkan pola distribusi dari kondrit sedangkan Gambar IV.10a. bagian atas memperlihatkan pola distribusi dari dua conto basalt dari daerah penyelidikan yang belum dinormalisasi dengan kondrit. Beberapa hasil perajahan dari unsur-unsur yang dianalisis memperlihatkan pola yang tidak rata (perbedaannya sangat tajam). Pada Gambar IV.10b nampak grafik yang relatif landai dari data UTL yang telah dinormalisasi dengan membagi setiap angka kelimpahan UTL dengan unsur-unsur sejenis dari kondrit.

\subsubsection{Kondrit}

Kondrit didefinisikan sebagai salah satu batuan meteorit jenis aglomerat yang mempunyai kesamaan dalam hal komposisi kimiawi dengan matahari; setidak-tidaknya mempunyai kesamaan dalam kandungan hidrogen, helium serta unsur-unsur yang mempunyai kadar atsiri (volatile) tinggi lainnya (Dodd, 1981 hal.13, dikutip dari Middlemost, 1985 hal. 178). Dengan demikian kelimpahan UTL dari kondrit dapat juga diharapkan mempunyai kesamaan dengan kelimpahan unsur-unsur sejenis dari sistem nebula solar darimana matahari, planet, serta meteorit berasal.

Kondrit dapat digolongkan ke dalam tiga jenis yaitu ordinary chondrites, carbonaceous chondrites dan enstatite chondrites yang mana masing-masing golongan dicirikan oleh angka perbandingan $\mathrm{Mg} / \mathrm{Si}, \mathrm{Ca} / \mathrm{Si}, \mathrm{Ti} / \mathrm{Si}$, dan $\mathrm{Al} / \mathrm{Si}$ tertentu. Ordinary dan enstatite chondrites dicirikan oleh gejala rekristalisasi akibat 


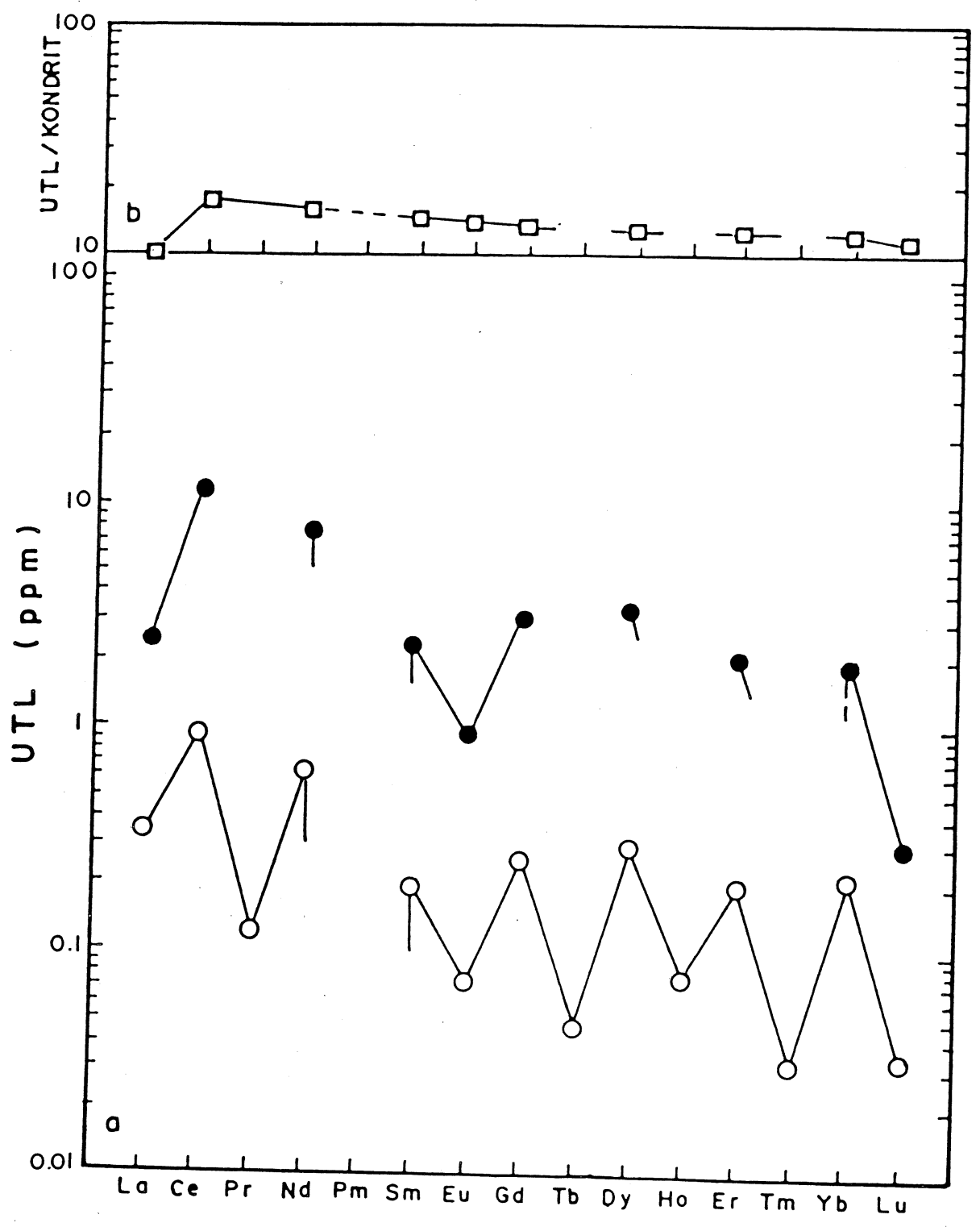

Gambar IV.10. Metode normalisasi kelimpahan UTL dengan kondrit : ......kondrit, $\bullet:$ basalt daerah penyelidikan, $\square$ : hasil normalisasi 
metamorfosis; carbonaceous chondrites pada umumnya tidak mengalami metamorfosis atau termetamorfosis lemah, dicirikan oleh adanya kondrul (chondrules) yaitu semacam agregat terdiri dari olivin dan piroksen, dan agregat lainnya yang tidak meleleh (unmelted aggregates), tertanam di dalam masadasar berbutir halus dan kaya akan unsur atsiri. Berdasarkan perbandingan unsur-unsur utama, serta kriteria petrografi carbonacous chondrites digolongkan ke dalam 4 kelompok yaitu I, M, O, dan V. Dari keempat jenis carbonacous chondrites tersebut, tipe I dianggap jenis kondrit yang mewakili material hasil fraksinasi dari sistem solar yang mempunyai komposisi paling primitif (mirip dengan material asal). Maka dari itu sebagai perbandingan dalam mempelajari pola kelimpahan unsur tanah langka (UTL) batuan dalam kaitan dengan petrogenesis, digunakan data kelimpahan UTL dari carbonaceous chondrites type I (C.I.).

\subsubsection{Diagram-diagram normalisasi kondrit}

Dewasa ini diketahui bahwa kelimpahan UTL serta pola fraksinasi magma di dalam suatu daerah volkanis secara sistematis bervariasi sesuai dengan komposisi mineralogi dan kimiawi magma tersebut (Schilling \& Winchester 1969, dari Schilling 1971). Lebih lanjut dijelaskan bahwa secara konsisten terlihat adanya kenaikan secara tetap dalam kandungan UTL ringan (light rare earth element $=L R E E)$ sesuai dengan kenaikan tingkat alkalinitas lava tanpa memperhatikan masalah tingkat kejenuhan terhadap silika. (Gambar IV.11). Informasi tentang pola UTL di dalam batuan volkanis ( basalt \& diabas) dapat membantu pemecahan tentang permasalahan genesis himpunan batuan ofiolit lainnya (gabro dan batuan utlramafis) yang berkaitan dengan batuan volkanis tersebut.

Gambar IV.12a, b, c, memperlihatkan hasil perajahan di dalam diagram semi logaritme hasil normalisasi UTL (berturut-turut a: basalt, b: diabas, serta c: gabro Karangsambung Utara) versus kenaikan nomer atomnya. Dari diagram tersebut terlihat bahwa basalt mempunyai pola fraksinasi yang relatif mendatar dengan sedikit melengkung ke bawah ke arah $\mathrm{La}$ (lantanum). Hal ini menunjukkan adanya 


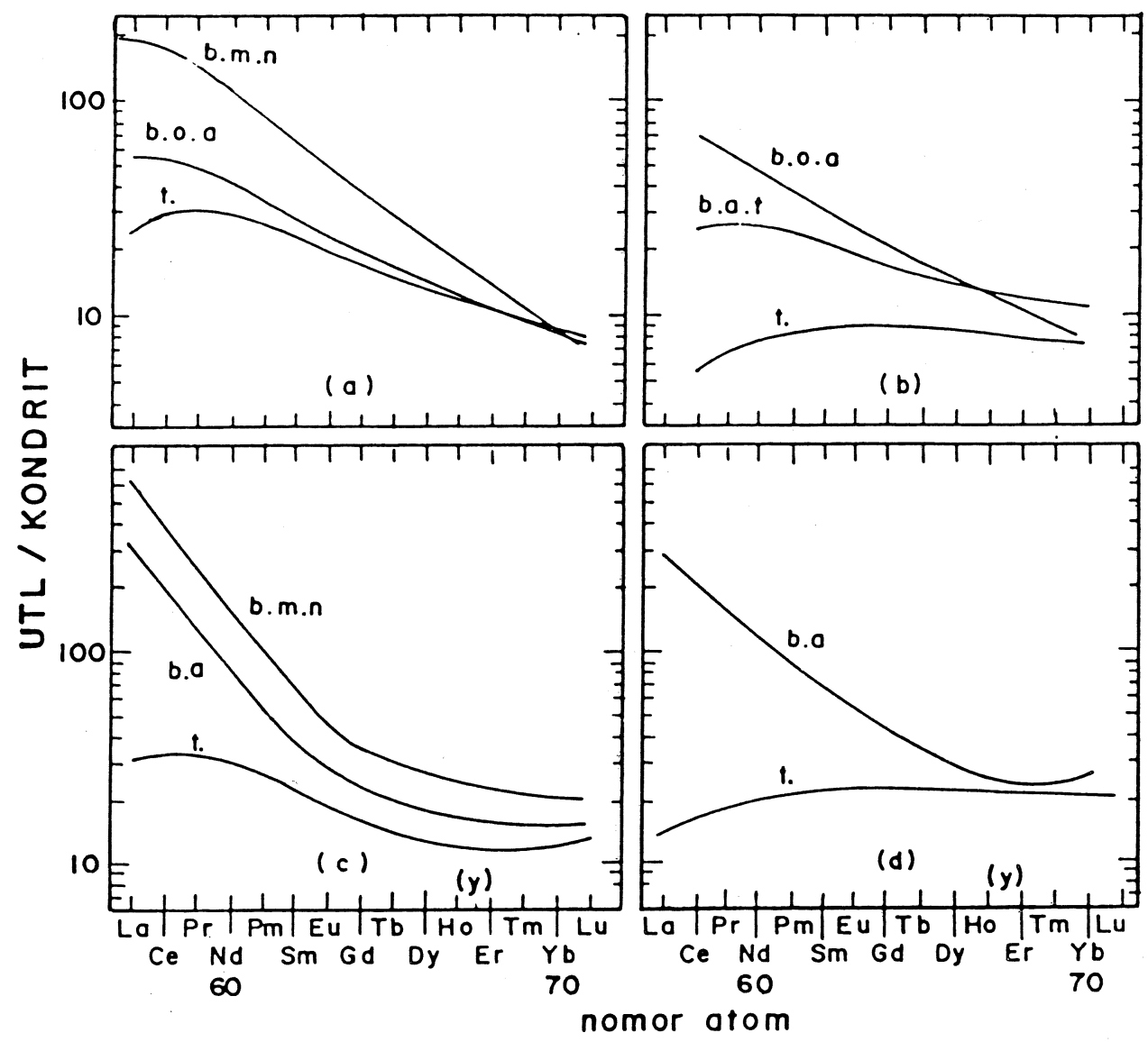

Gambar IV.11. Pola fraksinasi UTL basalt toleit ( $\mathrm{t}$ ) dan macam-macam basalt alkali dari berbagai tempat di dunia; khusus pada Gambar IV.11d terlihat pola fraksinasi basalt toleit dari punggung tengah samudera (Schilling, 1971), b.m.n = basalt melilit nefelin, b.o.a $=$ basalt olivin-alkali, b.a.t $=$ basalt alumina tinggi, $\mathrm{b} . \mathrm{a}=$ basalt alkali, $\mathrm{t}=$ toleit. 

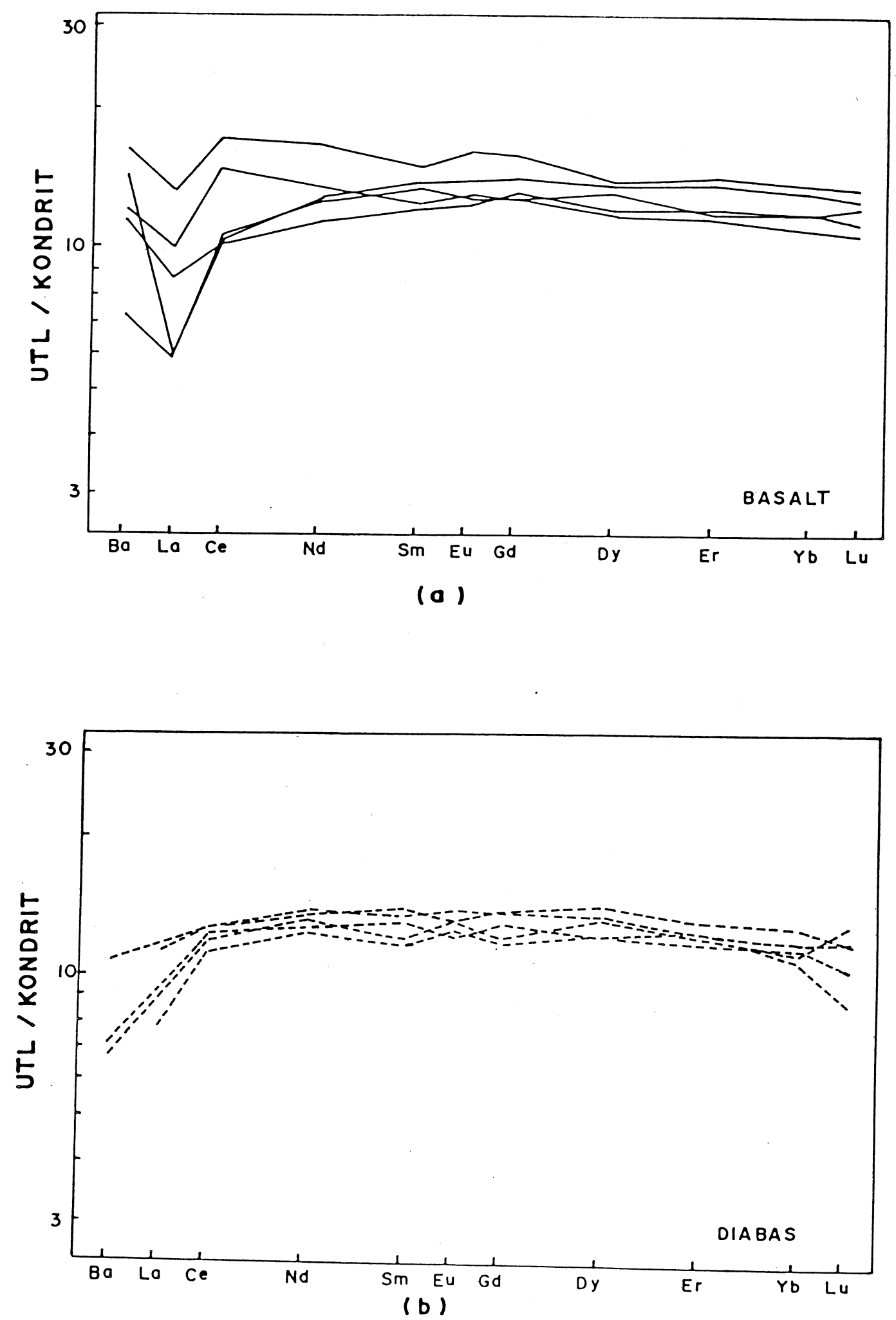

Gambar IV.12. Pola fraksinasi UTL batuan basalt (a) dan diabas (b) daerah penyelidikan. 


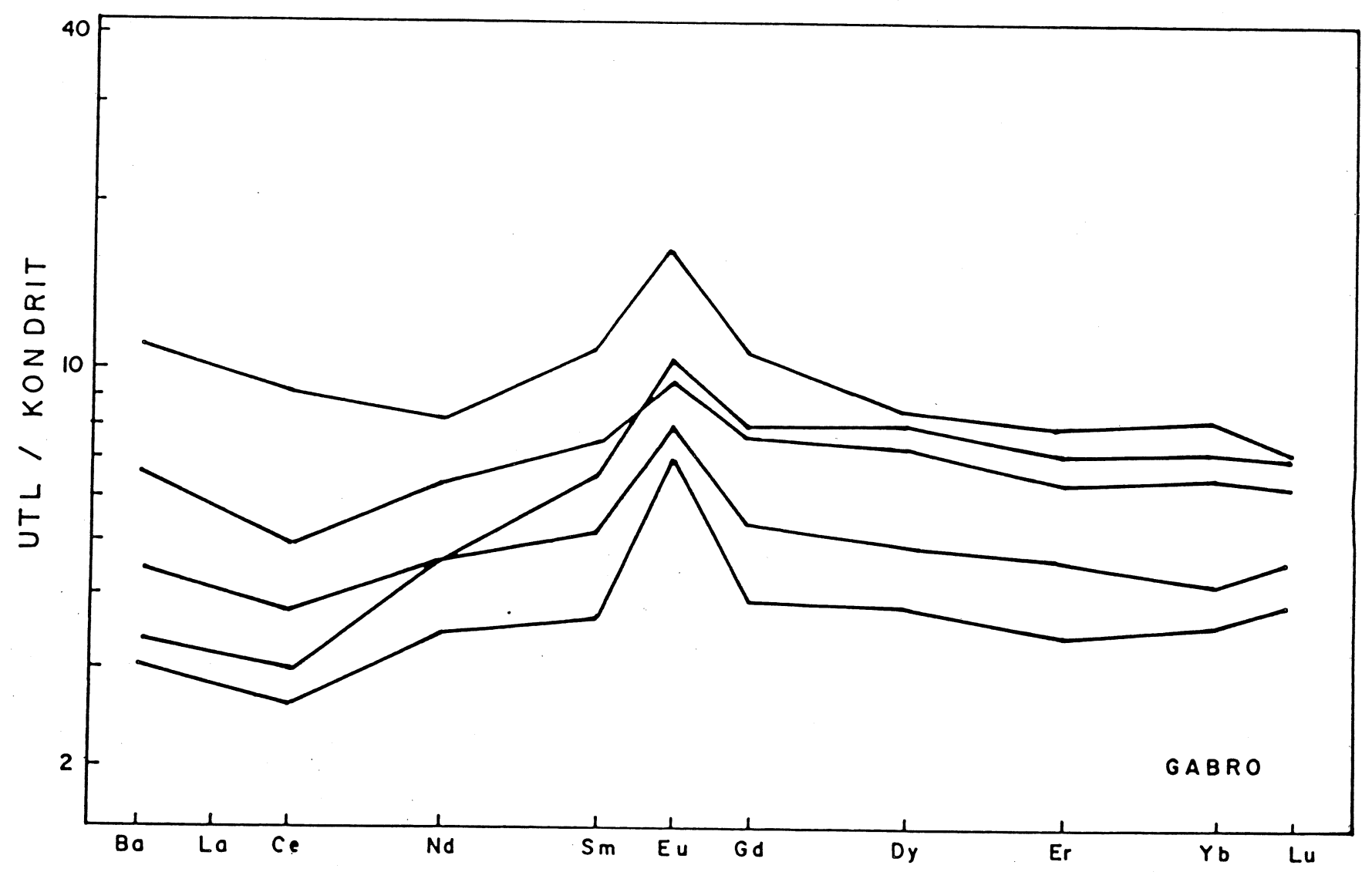

Gambar IV.12c Pola fraksinasi UTL batuan gabro daerah penyelidikan. 
pengurangan (depletion) relatif ke arah UTL ringan, dan secara berangsur terjadi peningkatan kelimpahan ke arah UTL yang lebih berat (heavy rare earth element $=H R E E$ ); kemudian menjadi relatif konstan pada UTL yang lebih berat; sedangkan nilai perbandingan dengan kondrit mencapai 10 kali lipat. Kenampakan pola yang demikian merupakan ciri khas dari basalt yang bersifat toleit (Schilling, 1971).

Pola yang hampir sama teramati pada batuan diabas. Secara umum menunjukan pola yang mendatar, dengan sedikit pengurangan kelimpahan pada Eu (europium) ditunjukkan dengan adanya anomali negatif pada pola fraksinasi. Batuan gabro memperlihatkan pola yang agak berbeda, di mana kandungan UTL-nya yang lebih sedikit jika dibandingkan dengan batuan basalt dan diabas. (mencapai perbandingan kurang dari 10 kali lipat kondrit). Polanya dicirikan oleh anomali (positif) yang cukup besar di dalam unsur Eu, disertai pengurangan (depletion) ke arah unsur tanah yang lebih ringan.

\subsubsection{Beberapa diagram log - log unsur tanah langka}

Di dalam kaitannya dengan pemecahan permasalahan mengenai genesis himpunan batuan ofiolit, terutama dalam hal hubungan antar batuan di dalamnya, salah satu metoda yang digunakan adalah dengan mempelajari model sifatsifat/karakteristik dari unsur-unsur jejak (termasuk UTL) selama proses-proses magmatis terjadi. Untuk itu harus diperhitungkan bahwa pembentukan ofiolit merupakan hasil dari dua gejala magmatis, yaitu periode pelelehan sebagian (partial melting) pada mantel yang menghasilkan pemisahan larutan primer (primary liquid) dari residu padat (residual solid), dan periode kristalisasi fraksional di dalam dapur magma (Allegre et al.,1977). Secara skematis urutan pembentukan ofiolit tersebut dapat dilihat pada Gambar IV.13. Dengan penjelasan sebagai berikut :

a. Lava bantal, diabas, gabro serta plagiogranit dapat saling berhubungan secara ko genetis sebagai hasil dari proses kristalisasi fraksional.

b. Sekuen lava bantal bagian atas umumnya dapat dianggap sebagai batuan 


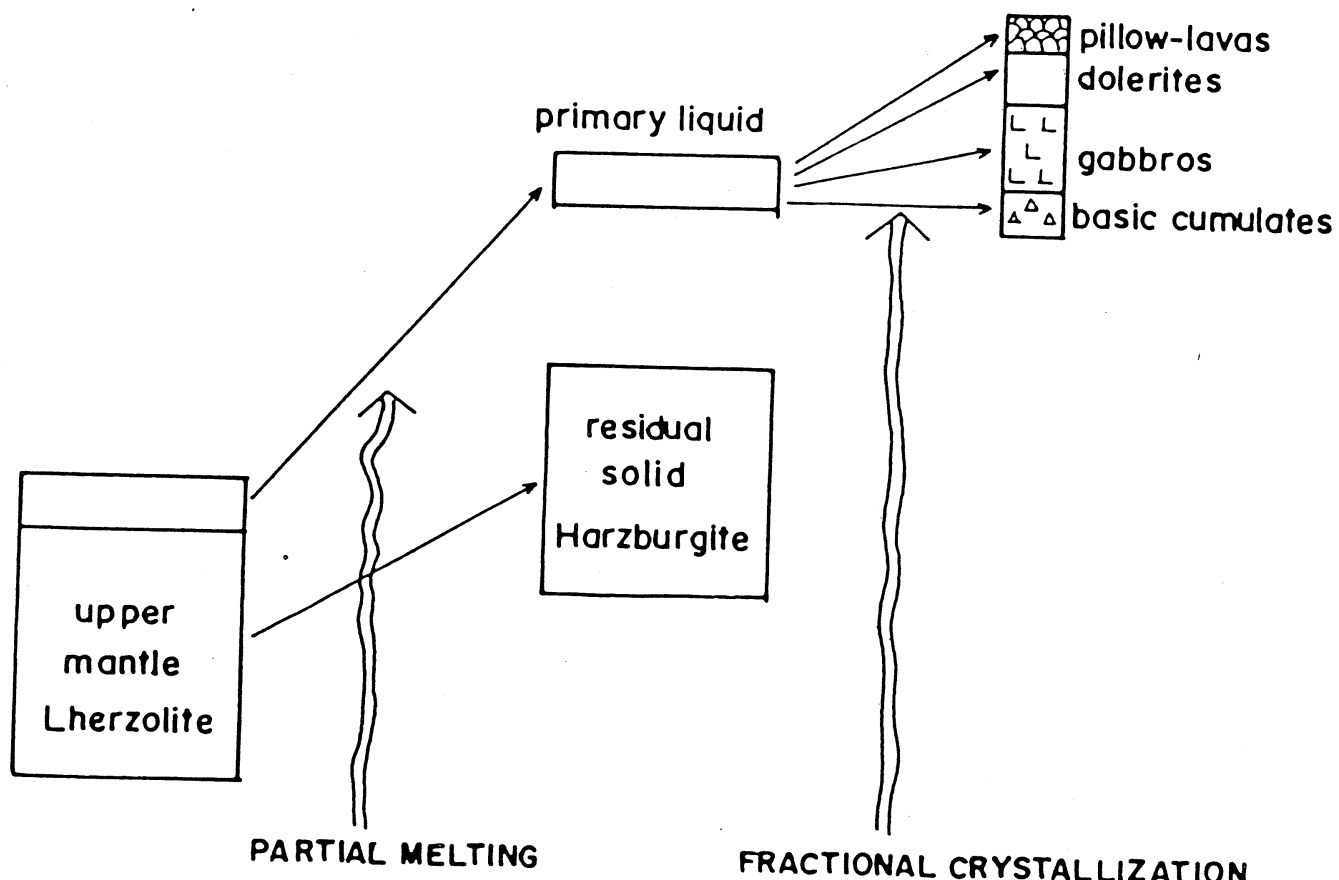

Gambar IV.13. Diagram yang memperlihatkan pembentukan ofiolit (Allegre, 1978). 
hasil diferensiasi.

c. Diabas dapat digolongkan ke dalam dua jenis; yaitu diabas yang termasuk di dalam komplek retas yang hanya memotong bagian atas, dan jenis yang memotong seluruh bagian dari komplek gabro masif. Jenis yang disebut terakhir ini merupakan conto batuan yang paling baik untuk digunakan dalam merefleksikan komposisi larutan magma primer (primary liquid); begitu juga dengan lava bantal bagian bawah.

d. Gabro mewakili fase kumulat, yang merupakan hasil dari kristalisasi magma primer.

e. Kadang-kadang terjadi penerobosan dari magma yang baru ke dalam dapur magma; dengan demikian akan terjadi percampuran magma, seperti yang teramati pada ofiolit yang terdapat di Inzecca (Corsica), dan Troodos (Siprus). Sedangkan ofiolit dari daerah Vourinos (Junani) merupakan salah satu conto dari ofiolit terbentuk akibat satu episode intrusi magma.

Penilaian ko genetis atau tidaknya masing-masing batuan mafis yang tercakup di dalam komplek ofiolit (yaitu basalt, diabas, serta gabro), dapat dipelajari dengan diagram yang membandingkan beberapa UTL yang ringan dengan yang lebih berat. Hasil yang sama akan diperoleh dari berbagai diagram yang membandingkan unsur-unsur transisi seperti $\mathrm{Ni}, \mathrm{Ti}, \mathrm{V}, \mathrm{Nb}$, dan $\mathrm{Zr}$ dengan salah satu UTL. Apabila perajahan di dalam diagram-diagram tersebut memperlihatkan adanya korelasi yang positif baik dari batuan volkanis maupun batuan gabro, maka dapat disimpulkan bahwa himpunan batuan tersebut ko genetis; grafik tersebut ditandai oleh satu garis lurus dengan sudut lereng tertentu atau dua garis lurus yang sejajar. Sedangkan apabila pola distribusinya tidak berupa garis lurus ataupun tidak saling sejajar menunjukkan bahwa himpunan batuan tersebut tidak ko genetis (Allegre et al., 1977; Allegre et al., in prep.).

Perajahan himpunan batuan basalt, diabas, dan gabro dari ofiolit Karangsambung Utara dapat dilihat pada Gambar IV.14a, b dan c; diagram log-log dari Ce - Nd, Sm - Nd, dan antara unsur Er - Yb menunjukkan adanya pola linier 


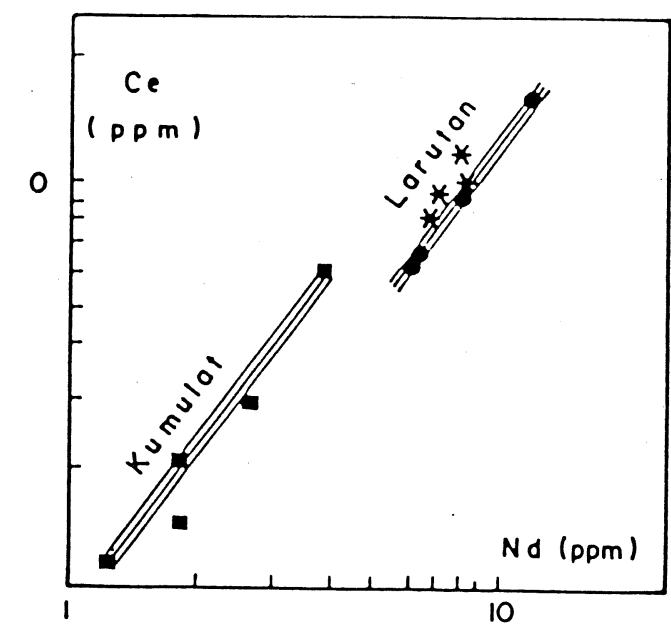

(a)

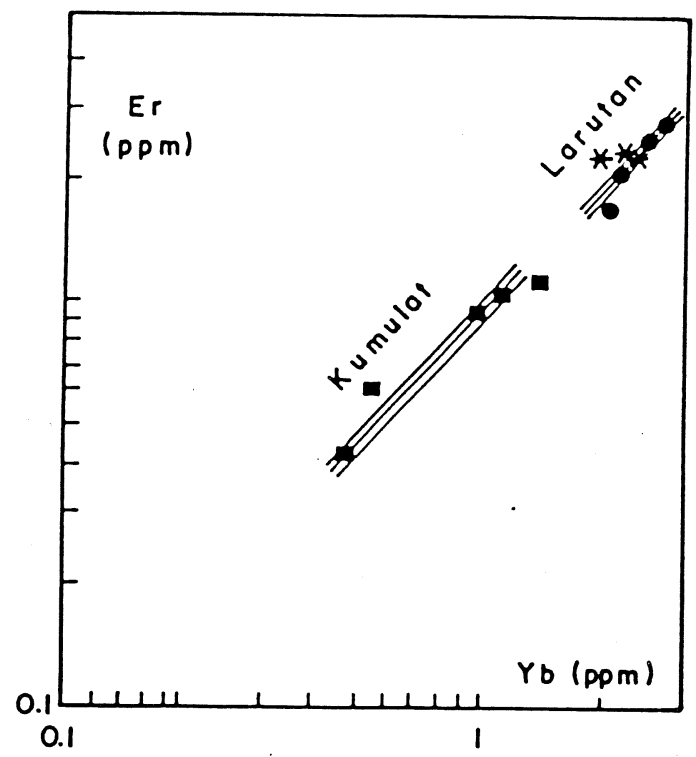

(b)

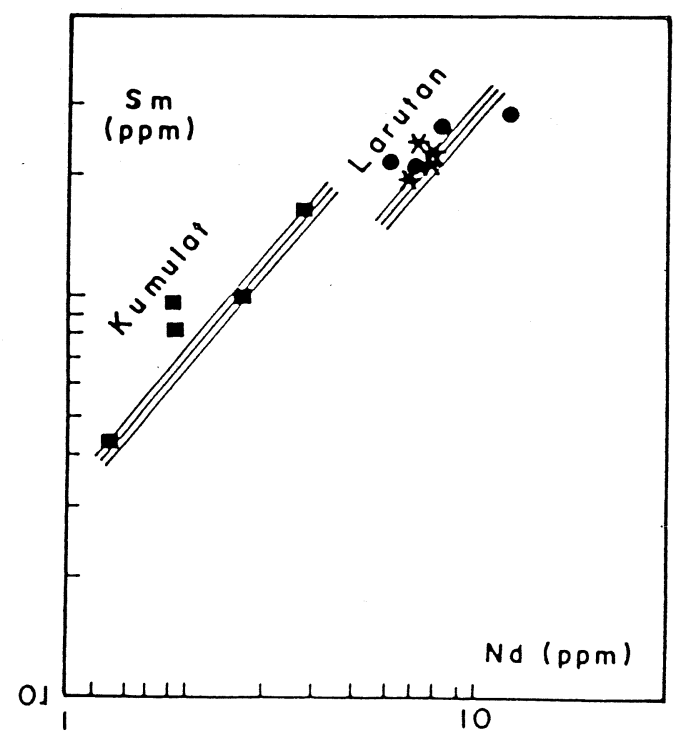

(c)

Gambar IV.14. Perajahan batuan basalt (•), diabas (*) dan gabro (-) di dalam diagram log - log Ce-Nd (a), Er-Yb (b) dan Sm-Nd (c). 
dan juga merupakan garis-garis linier yang sejajar. Dengan demikian dapat dianggap bahwa batuan basalt, diabas, serta gabro di dalam komplek ofiolit ini mempunyai hubungan yang ko genetis.

\subsection{Kesimpulan}

Dari pembahasan petrologi dan geokimia himpunan batuan ofiolit di daerah penyelidikan dapat disimpulkan bahwa :

- Hasil analisis kimia batuan basalt, diabas, serta gabro dari komplek ofiolit di daerah ini menunjukkan pola kimia yang khas untuk batuan yang berafinitas toleit; batuannya dicirikan oleh kandungan $\mathrm{SiO}_{2}$ yang variasinya kecil, $\mathrm{Al}_{2} \mathrm{O}_{3}$ yang sangat bervariasi, rendahnya kadar $\mathrm{K}_{2} \mathrm{O}$ serta $\mathrm{P}_{2} \mathrm{O}_{5}$, dan adanya peningkatan unsur besi pada perioda kristalisasinya. Dari data tersebut dan kenyataan bahwa $\mathrm{Ni}$ serta $\mathrm{Cr}$ yang relatif tinggi dengan nilai $\mathrm{FeO}^{*} / \mathrm{MgO}$ relatif kecil (tidak lebih dari 2), merupakan ciri dari batuan toleit samudera/ laut dalam (abisal).

- Ciri kimia lainnya adalah nilai perbandingan antara unsur Ti dan V yang berkisar antara 20 - 50, dimana kadar $V$ bervariasi antara 92-280 ppm dan $\mathrm{Ti}$ antara 2000-6500 ppm, menurut Shervais (1982) hal ini menunjukkan lingkungan punggung tengah samudera. Kesimpulan ini diperkuat oleh hasil analisis mikroprob dari piroksen dalam gabro dan basalt yang memperlihatkan karakter komposisi piroksen khas untuk batuan yang terbentuk di daerah non orogenik (termasuk diantaranya daerah abisal tengah samudera).

- Pola fraksinasi dari UTL dari basalt menunjukkan kesamaan dengan pola dari basalt yang berasal dari punggung tengah samudera (Gambar IV.15a) atau lebih tepatnya tergolong ke dalam basalt punggung tengah samudera tipe N (Sun et al. 1979) seperti juga basalt yang diketemukan di beberapa punggung samudera di samudera Atlantik, Pasifik dan India (Gambar IV.16). Pola normalisasi dengan kondrit menunjukkan hasil mencapai 10 kali lipat dengan pola fraksinasinya relatif mendatar, dan sedikit pengurangan (depletion) ke arah unsur tanah langka yang ringan. Pola ini sangat berbeda 


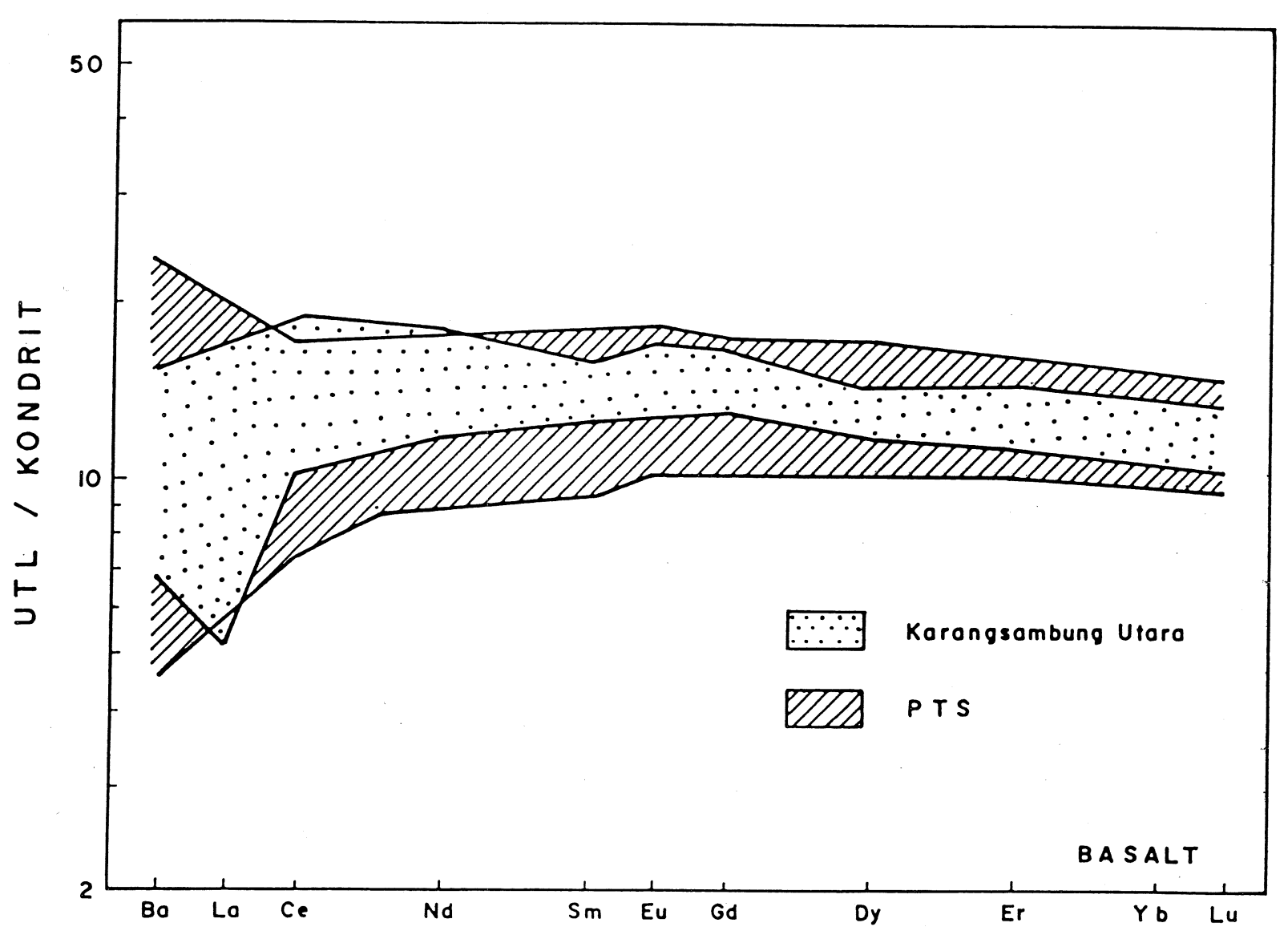

Gambar IV.15. Pola fraksinasi UTL basalt daerah penyelidikan dibandingkan dengan pola fraksinasi UTL umum dari basalt PT (punggung tengah samudera). 


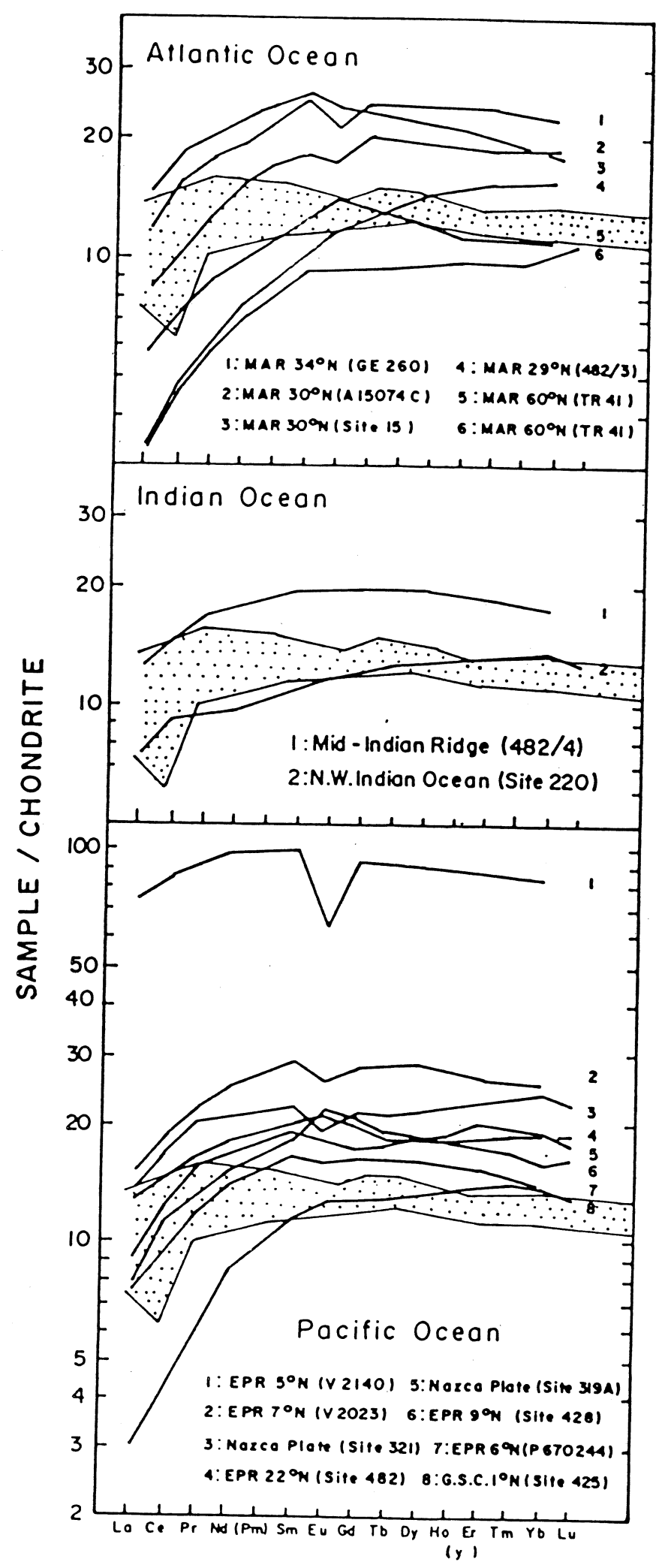

Gambar IV.16. Pola fraksinasi UTL basalt daerah penyelidikan disebandingkan dengan pola fraksinasi basalt toleit tipe-N, dari beberapa punggung tengah samudera (dikutip dari Sanders, 1984). : daerah Karangsambung Utara 
dengan pola fraksinasi yang dimiliki oleh batuan toleit yang berasal dari daratan. Yang disebut terakhir ini dicirikan oleh kelimpahan UTL yang ringan relatif lebih tinggi dibandingkan dengan kadar unsur yang sama untuk kondrit sehingga menghasilkan pola yang meningkat ke arah UTL yang lebih ringan, dan menurun secara agak tajam ke arah UTL yang lebih berat; distribusi unsur Eu nampak relatif konstan, atau menurun dengan landai (Gambar IV.17).

- $\quad$ Anomali negatif Eu (Eu lebih kecil kelimpahannya daripada Sm dan Gd) pada pola fraksinasi diabas daerah penyelidikan menunjukkan bahwa sebelum magma naik telah terjadi ektraksi plagioklas; dengan demikian pada larutan sisa terdapat pengurangan unsur Eu yang direfleksikan dalam pola fraksinasi dengan anomali negatif pada Eu. Kejadian ini dapat pula dibuktikan secara mikroskopis dengan adanya fenokris plagioklas pada beberapa conto diabas.

- Komplek batuan ofiolit di daerah penyelidikan merupakan hasil diferensiasi magma toleit yang menghasilkan gabro, diabas, dan basalt pada punggung tengah samudera. Sebagai tambahan dapat disimpulkan bahwa diabas yang diketemukan di dalam komplek ofiolit di daerah ini berupa retas yang memotong komplek gabro masif. Retas diabas tersebut memperlihatkan pola fraksinasi UTL yang mempunyai kesamaan dengan basalt yang dalam hal ini mewakili komposisi magma primer. Begitu juga di dalam perajahan pada diagram log-log distribusi dari diabas selalu bersamaan dengan basalt.

- Batuan sedimen yang seringkali dijumpai berasosiasi dengan ofiolit di daerah Karangsambung Utara adalah batugamping-rijang. Batugamping-rijang mempunyai hubungan yang erat dalam lingkungan pembentukannya dengan lava basalt sebagai anggota dari ofiolit. Untuk memperoleh hasil yang lebih rinci, terhadap dua conto batuan sedimen tersebut dilakukan analisis UTL dan menghasilkan pola fraksinasi UTL yang dapat dilihat pada Gambar IV.18. Anomali negatif yang cukup besar teramati pada unsur Eu, yang secara 


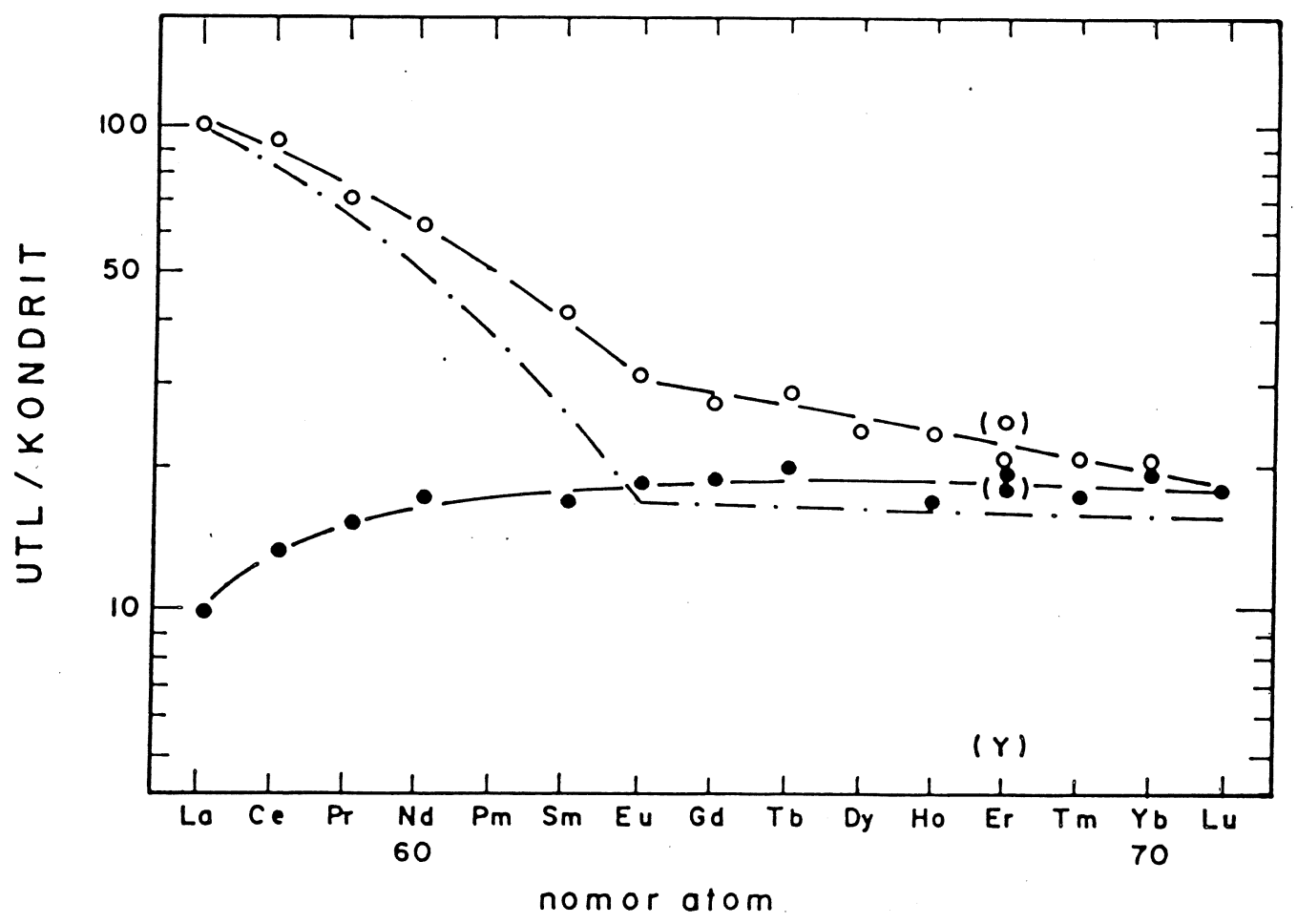

Gambar IV.17. Pola fraksinasi UTL dari basalt toleit punggung tengah samudera $(\bullet)$ dan benua $(-\&-$ - -$)$ dari beberapa tempat di dunia (dimodifikasi dari Schilling, 1971). 


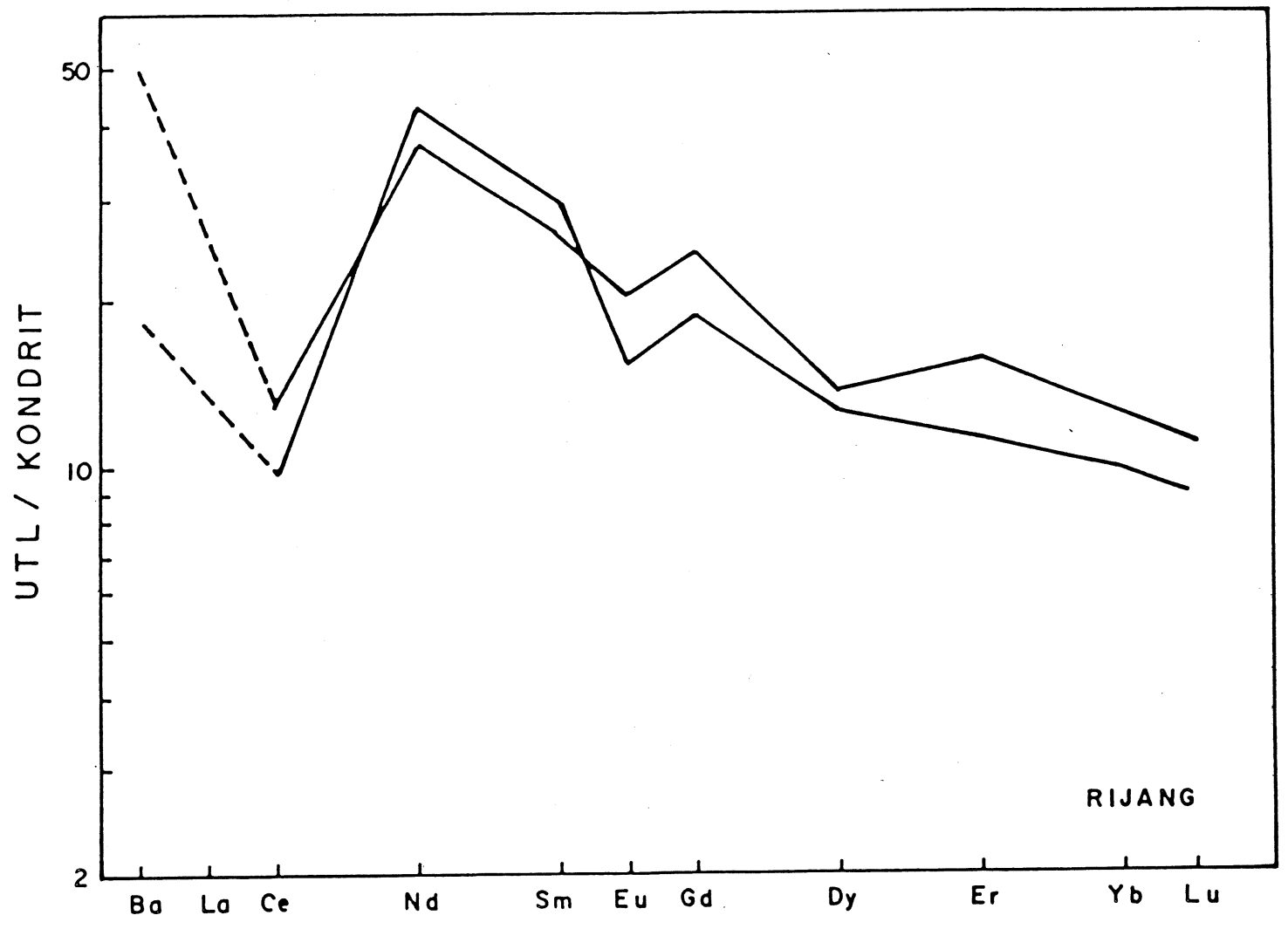

Gambar IV.18. Pola fraksinasi UTL rijang Karangsambung Utara. 
keseluruhan menunjukkan penurunan ke arah unsur-unsur yang relatif lebih berat. Pola tersebut mencirikan lingkungan laut dalam (abisal). Adanya anomali negatif dari unsur Ce (serium) dapat dijelaskan dengan adanya komponen biogenik yang mengakibatkan berkurangnya unsur Ce; sedangkan anomali positif unsur Eu pada pola batuan sedimen menunjukkan banyaknya material lempung dan material jejak dari material oxyhydroxides yang mengakibatkan pengayaan unsur Eu (Goldberg et al.,1963, dikutip dari Tlig \& Steinberg, 1982). 


\section{BAB V \\ OFIOLIT PEGUNUNGAN MERATUS - BOBARIS}

Pegunungan Meratus dan Bobaris di Kalimantan Tenggara merupakan salah satu tempat dimana juga diketemukan komplek ofiolit (Gambar V.1). Daerah ini dipilih sebagai studi perbandingan mengingat adanya anggapan bahwa komplek ofiolit di Pegunungan Meratus-Bobaris mempunyai hubungan dengan ofiolit Karangsambung Utara dalam hal tatanan tektoniknya.

\subsection{Tinjauan geologi}

Informasi tentang geologi daerah tersebut telah banyak ditulis, diantaranya oleh Hooze 1893, Krol 1920, Koolhoven 1935, Van Bemmelen 1949, Hashimoto \& Koike 1974 (dikutip dari Yuwono et al.,1988), Katili (1976), Hamilton (1979), Situmorang (1982), Priyomarsono (1984), Sikumbang (1986), dan Yuwono et al. (1988). Dari tulisan yang disebutkan terakhir diperoleh informasi bahwa kedudukan komplek ofiolit (peridotite nappe) secara tektonik terletak di atas Formasi Alino, sedangkan secara tidak selaras komplek ofiolit tersebut ditutupi oleh Formasi Manunggul.

Pentarikhan umur absolut dari Formasi Alino, komplek ofiolit, serta Formasi Manunggul dilakukan dengañ metode K-Ar terhadap beberapa batuan volkanis yang mewakili ataupun yang berkaitan dengan ketiga satuan batuan tersebut. Hasilnya menunjukkan bahwa umur batuan andesit yang menerobos Formasi Alino adalah 79,9 土4,0 jt atau Campanian (Kapur Akhir bagian atas). Sedangkan komplek ofiolit yang diwakili oleh plagiogranit serta batuan meta dolerit (meta diabas) berturut-turut menunjukkan umur 96,7 $\pm 4,8 \mathrm{jt}$ dan $116 \mathrm{jt}$ atau Cenomanian dan Aptian. Pentarikhan umur dengan metode yang sama terhadap batuan terobosan berkomposisi dioritik dari Formasi Manunggul menghasilkan umur dari 86,9 \pm 4,4 jt sampai 72,2 $\pm 3,6 \mathrm{jt}$ atau Campanian sampai Maestrichtian (Kapur Akhir bagian tengah - atas). Perlu dijelaskan bahwa data pentarikhan umur yang disebutkan dalam pembahasan di atas seluruhnya dikutip dari Priyomarsono 


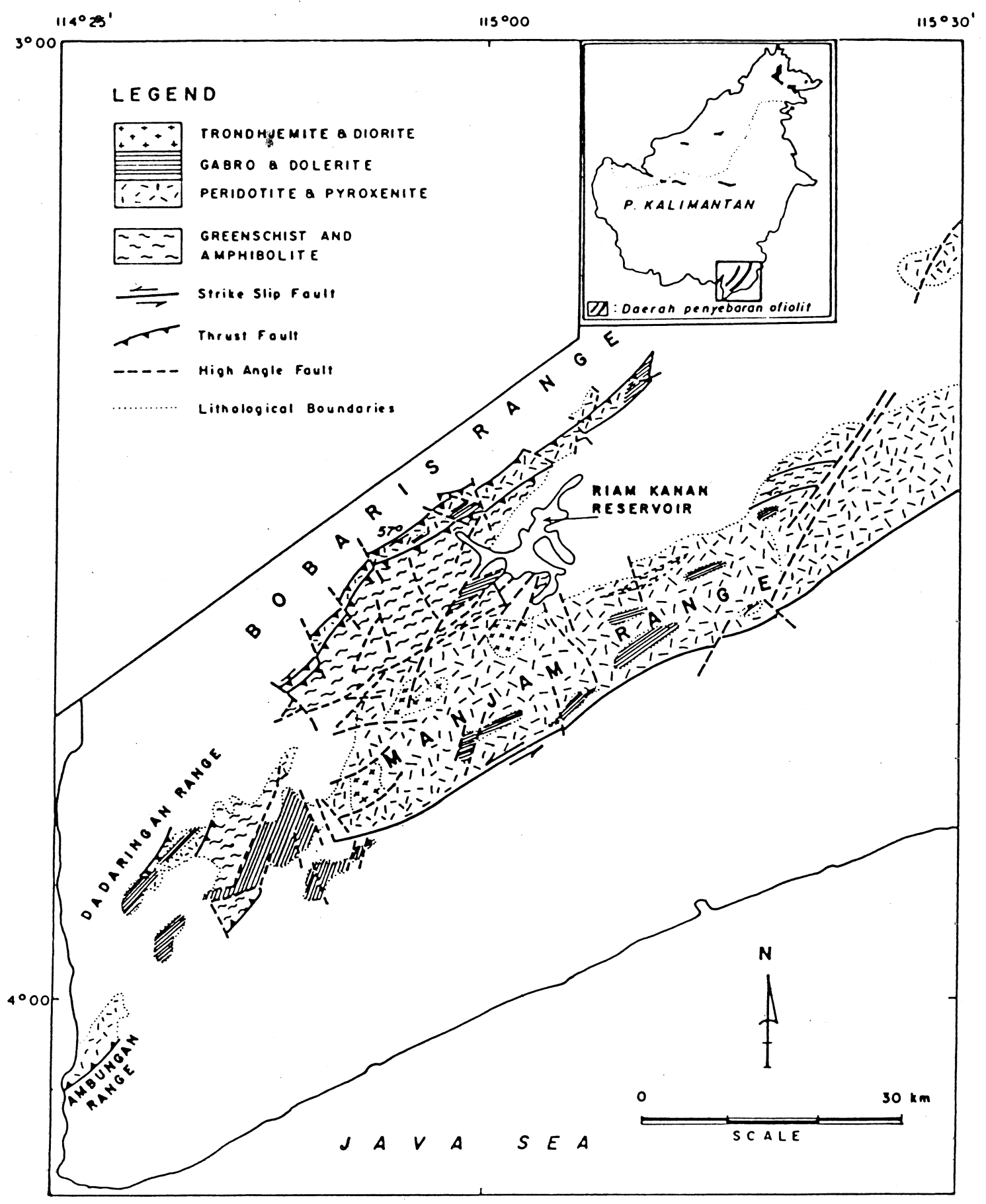

Gambar V.1. Distribusi dari unit batuan di dalam komplek ofiolit Meratus Bobaris (dimodifikasi dari Sikumbang, 1981). 
(1984) dan Yuwono et al.(1988), kecuali data pentarikhan meta diabas yang dikutip dari Sikumbang (1986).

\subsection{Petrologi dan geokimia}

Sebagai bahan untuk pembahasan di dalam sub bab 5.2 ini, digunakan data analisis kimia ofiolit Meratus-Bobaris yang dapat dilihat pada Tabel V.1a \& b. yang diperoleh dari DR. K.P. Burgath dari BGR. Pada Tabel V.1a \& b terlihat bahwa jumlah H.D. berkisar antara 1-4,6\% untuk batuan mafisnya, sedangkan batuan ultramafis pada umumnya mempunyai nilai H.D. lebih besar mencapai $15 \%$. Hal ini menunjukkan intensitas proses ubahan yang dialami oleh batuan, seperti proses hidrotermal, metamorfosis, dan juga pengaruh pelapukan. Sebelum data tersebut diolah (untuk kemudian dianalisis hasilnya), dilakukan seleksi terhadap hasil analisis kimia dari conto-conto batuan yang ada dengan cara sebagai berikut :

- Membandingkan hasil yang diperoleh dengan hasil analisis kimia serupa dari batuan sejenis yang dapat dipakai sebagai referensi.

- Hasil analisis kimia yang telah diseleksi kemudian dirajah di dalam diagram $\log -\log \mathrm{Ce}$ dan $\mathrm{V}$ versus La untuk mengelompokkan batuan mafis - ultramafis yang ko genetis (Gambar V.2.); dengan demikian dapat diyakini bahwa himpunan batuan tersebut adalah ofiolit (Allegre et al., in prep.).

\subsubsection{Beberapa diagram evolusi magma dan diskriminasi geokimia}

Untuk memperoleh data tentang afinitas dari batuan mafis - ultramafis yang tercakup di dalam komplek ofiolit Meratus dan Bobaris dipilih beberapa diagram diskriminasi dari Miyashiro \& Shido (1975), yang menggunakan unsur-unsur yang relatif immobile seperti $\mathrm{Ti}, \mathrm{Ni}, \mathrm{Cr}$ dan unsur yang agak mobile yaitu $\mathrm{Fe}$ dan $\mathrm{Mg}$.

Perajahan di dalam diagram-diagram $\mathrm{FeO}^{*}, \mathrm{TiO}_{2}$, dan $\mathrm{Ni}$ versus $\mathrm{Fe}^{*} / \mathrm{MgO}$ (Gambar V.3, V.4 dan V.5) diperoleh hasil bahwa ofiolit daerah ini terdiri atas percampuran antara batuan yang berafinitas toleit (toleit samudera) dan kalk alkali. Selanjutnya perajahan di dalam diagram V-Ti dari Shervais, 1982 (Gambar V.6.) menunjukkan bahwa distribusi dari sebagian besar conto batuan dari 

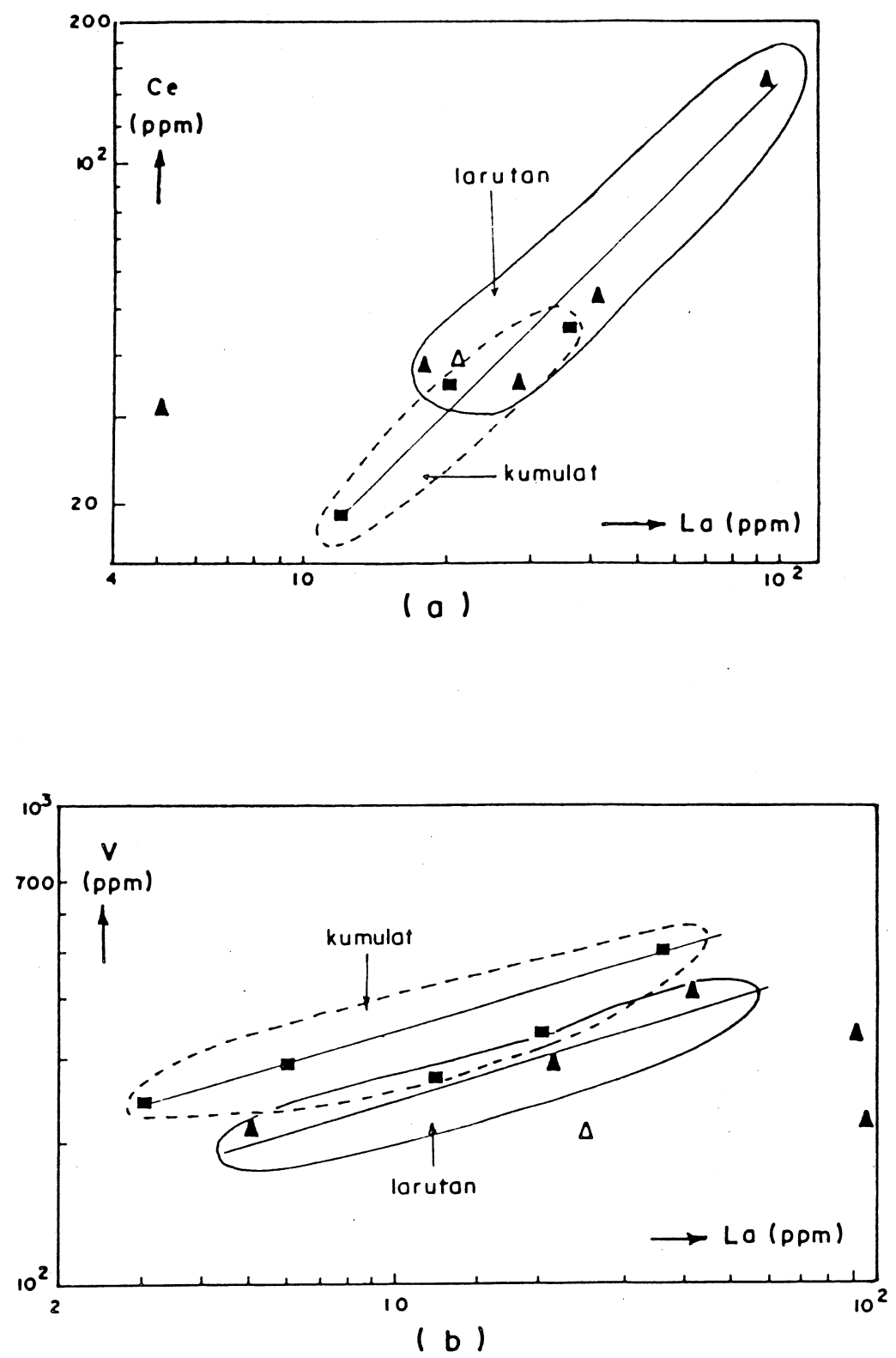

Gambar V.2a Perajahan ofiolit Meratus - Bobaris di dalam diagram log - log $\& b$ Ce \& V versus La; basalt $(\Delta)$, diabas ( $\mathbf{\Lambda}$ ) dan gabro $(\boldsymbol{\bullet})$. 


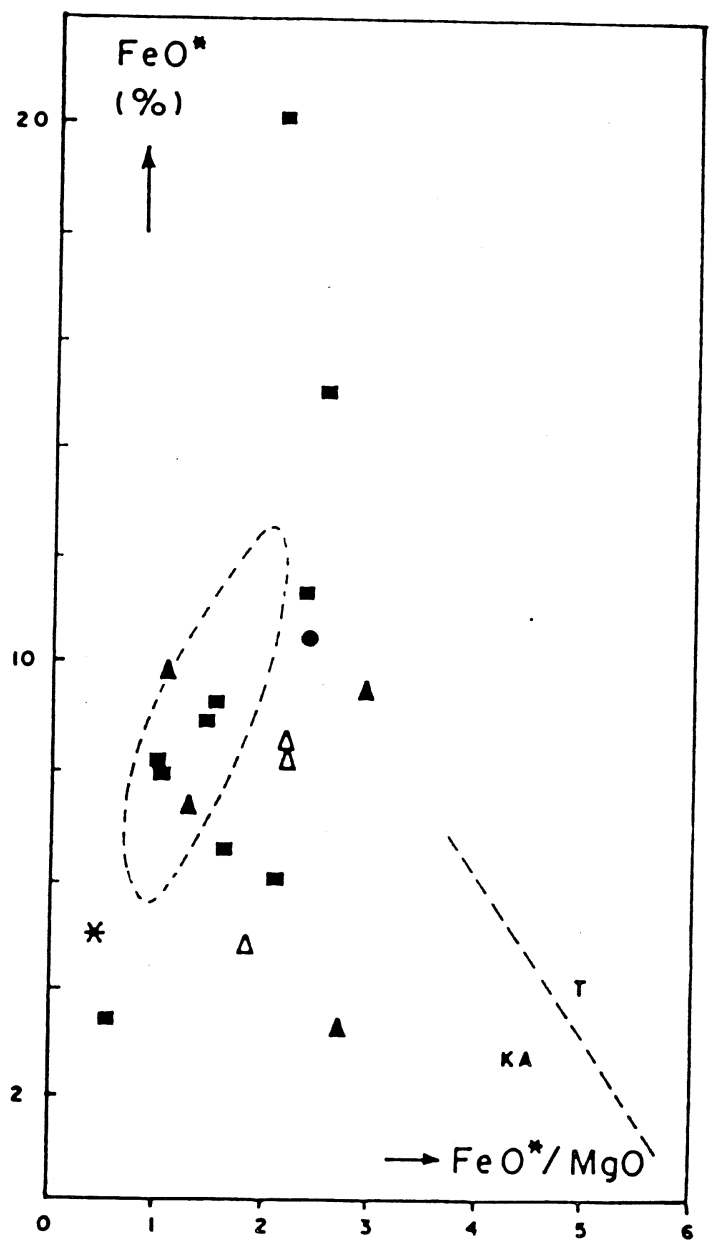

Gambar V.3. Distribusi batuan basalt ( $\Delta)$, diabas ( $(\mathbf{4})$, gabro (- ), piroksenit (*) dan dunit ( $)$ dari ofiolit Meratus - Bobaris di dalam diagram $\mathrm{FeO}^{*}-\mathrm{FeO}^{*} / \mathrm{MgO}$ (Miyashiro \& Shido, 1975).

$\therefore$ : basalt punggung tengah samudera \& basalt belakang busur 


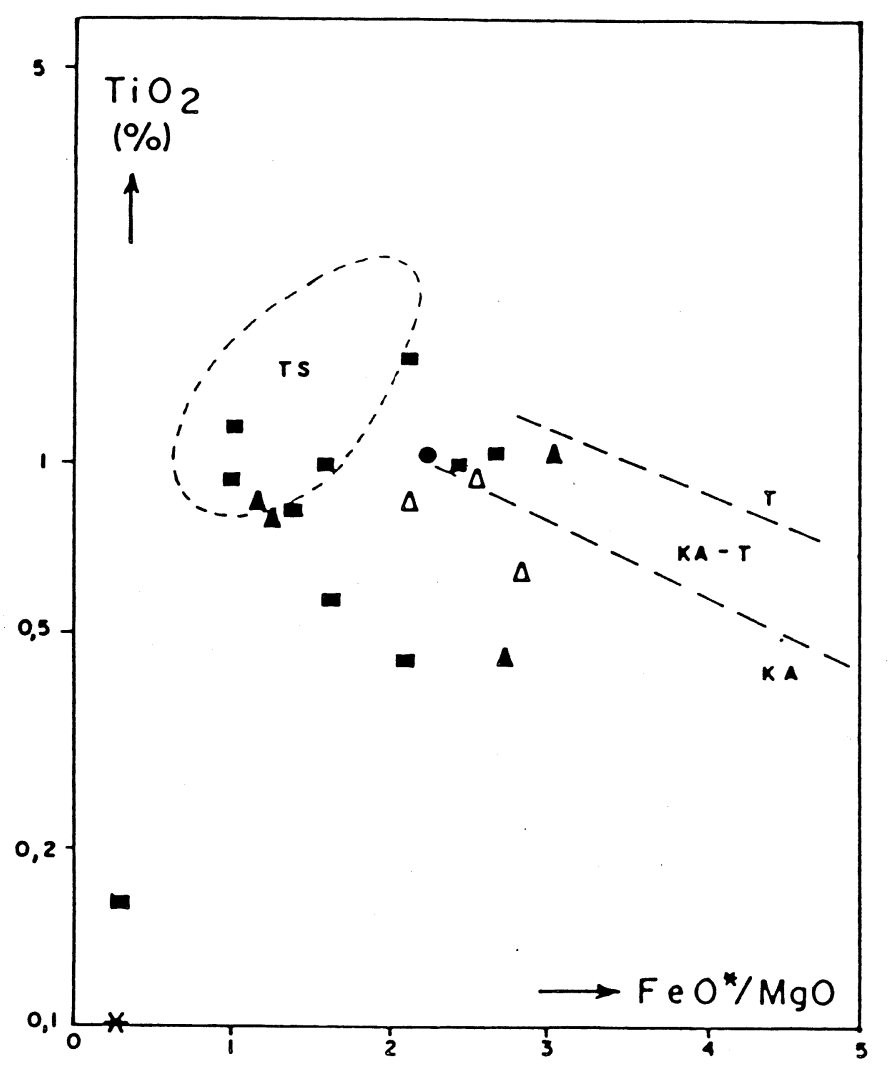

Gambar V.4. Distribusi batuan basalt ( $\Delta$ ), diabas ( $)$, gabro ( $)$, piroksenit (*) dan dunit (*) dari ofiolit Meratus - Bobaris di dalam diagram $\mathrm{TiO}_{2}-\mathrm{FeO}^{*} / \mathrm{MgO}$. 


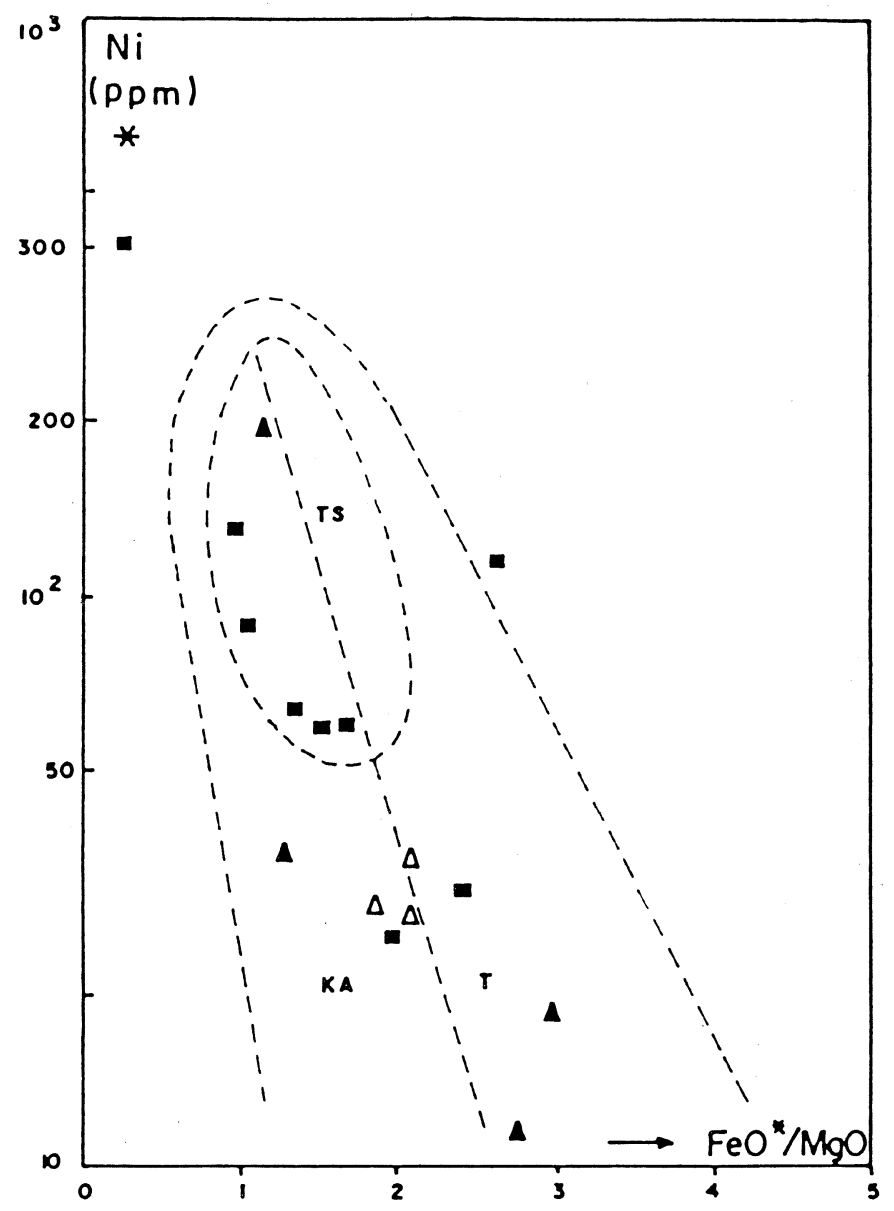

Gambar V.5 Distribusi batuan basalt ( () ), diabas ( $\mathbf{4})$, gabro (- ), piroksenit (*) dan dunit $(\bullet)$ dari ofiolit Meratus - Bobaris di dalam diagram $\mathrm{Ni}-\mathrm{FeO}^{*} / \mathrm{MgO}$. 


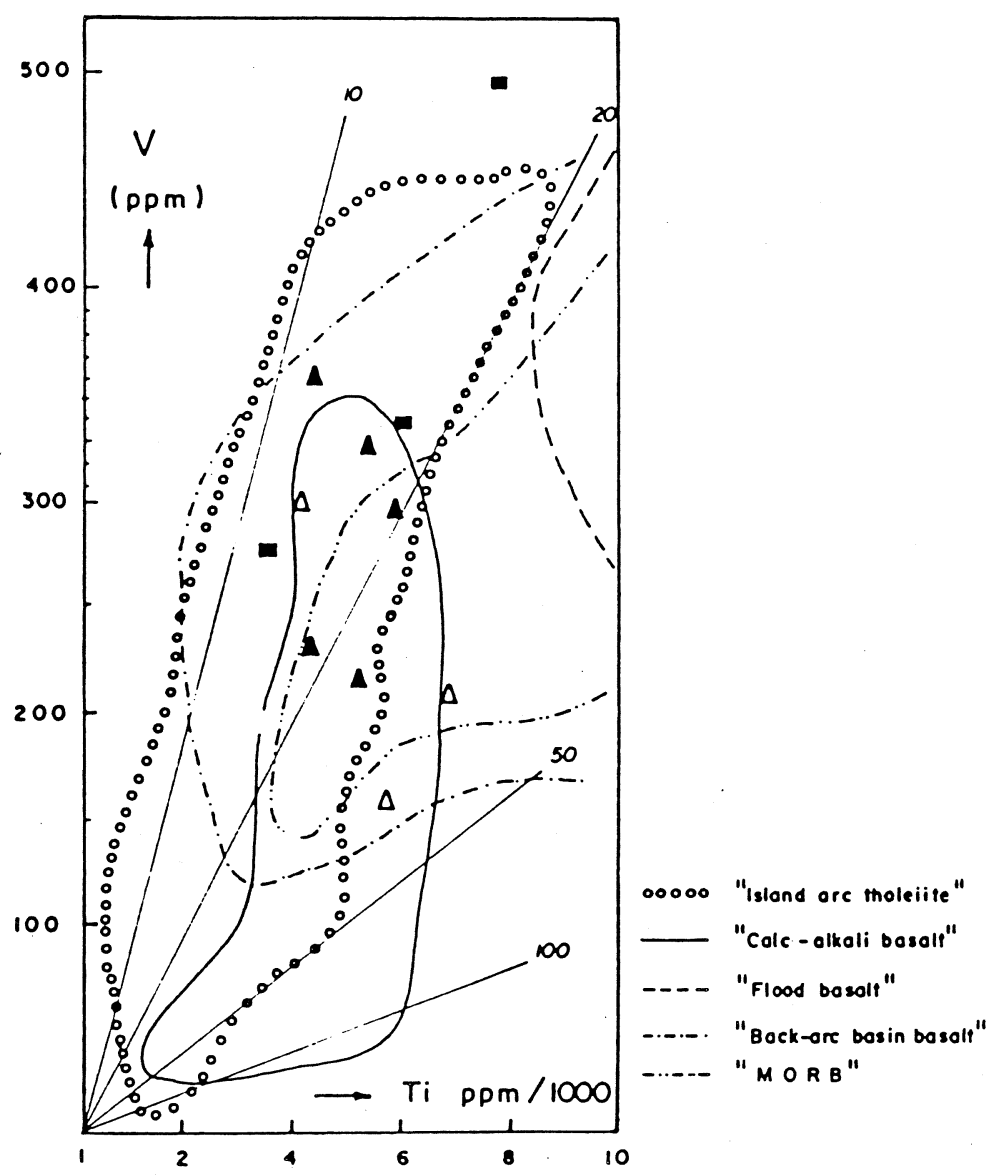

Gambar V.6. Distribusi batuan basalt ( $\Delta$ ), diabas ( $\mathbf{\Lambda})$, dan gabro (•) dari ofiolit Meratus-Bobaris di dalam diagram V-Ti/1000 (Shervais, 1982). 
komplek ofiolit terletak di daerah antara Ti/V 10-20; yang mana merupakan karakteristik dari batuan volkanis yang terbentuk di lingkungan busur kepulauan (island arc). Lebih lanjut dikatakan bahwa himpunan batuan yang terbentuk di lingkungan ini dapat terdiri atas batuan yang berafinitas toleitik, kalk alkali, ataupun shoshonitik (Shervais, 1982).

Hasil perajahan di dalam diagram $\mathrm{K}_{2} \mathrm{O}$ versus $\mathrm{SiO}_{2}$ dari Peccerillo \& Taylor (1976) menunjukkan adanya dua himpunan batuan yang berbeda, yaitu himpunan batuan yang tergolong ke dalam seri kalium rendah dan himpunan batuan dari seri kalk alkali (Gambar V.7). Himpunan batuan yang tergolong ke dalam seri kalium rendah ternyata memperlihatkan pola diferensiasi serupa dengan batuan seri toleit yang dicirikan oleh pengayaan akan unsur besi dan adanya batuan kumulat (Gambar V.8a). Sedangkan pada Gambar V.8b. dapat dilihat pola diferensiasi dari seri batuan kalk alkali. Dari hasil perajahan di dalam diagram Peccerillo and Taylor tersebut juga memperlihatkan beberapa batuan gabro dari ofiolit Meratus dan Bobaris yang tergolong ke dalam seri shoshonitik dan kalk alkali kalium tinggi.

\subsection{Kesimpulan}

Dari pembahasan petrologi dan geokimia himpunan batuan basalt, diabas, gabro serta batuan ultramafis dari komplek ofiolit Meratus - Bobaris dapat disimpulkan bahwa :

- Perajahan di dalam diagram log-log antara Ce, V dengan La menunjukkan bahwa himpunan batuan gabro (mewakili fase kumulat), diabas dan basalt (mewakili fase larutan) mempunyai hubungan ko genetis. Hubungan ko genetis ini ditandai oleh pola distribusi batuan gabro (di satu pihak) dan batuan diabas \& basalt (di lain pihak) terletak pada daerah yang sama atau saling,sejajar (Gambar V.2a \& b). Pola distribusi demikian menunjukkan bahwa himpunan batuan mafis - ultramafis daerah ini merupakan satu komplek ofiolit.

- Analisis kimia batuan volkanisnya memperlihatkan hasil sebagai berikut yaitu terdiri dari dua tipe, yaitu tipe toleit dan kalk alakali. Dicirikan oleh 


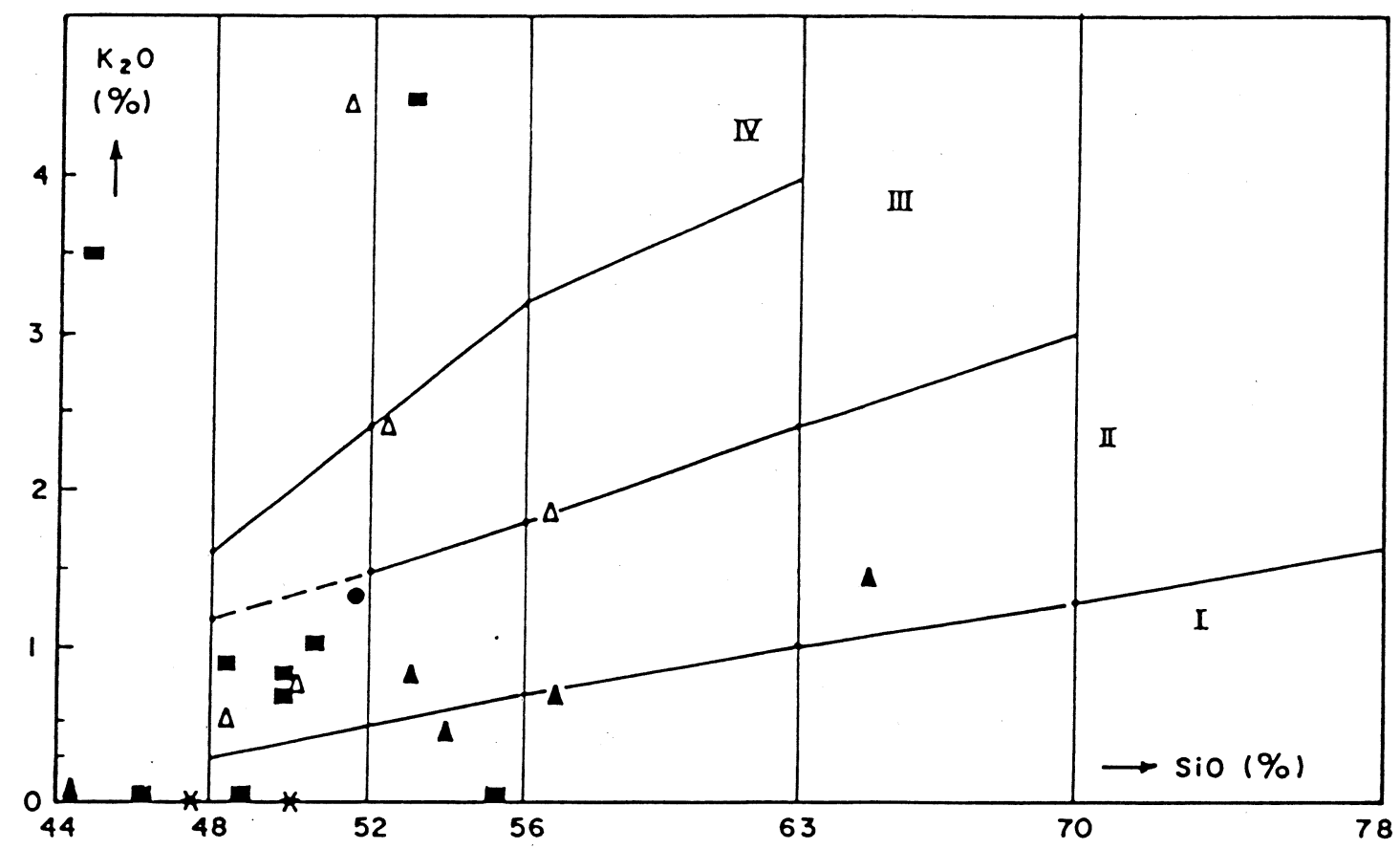

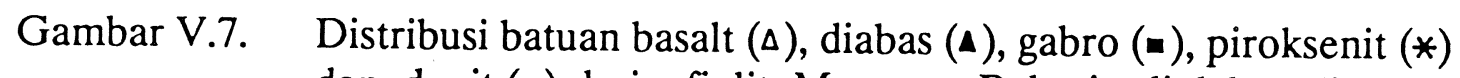
dan dunit $(\bullet)$ dari ofiolit Meratus - Bobaris di dalam diagram Pecerillo \& Taylor (1976).

I : seri kalium rendah (toleit)

II : seri kalk alkali

III : seri kalk alkali K-tinggi

IV : seri shoshonitik 

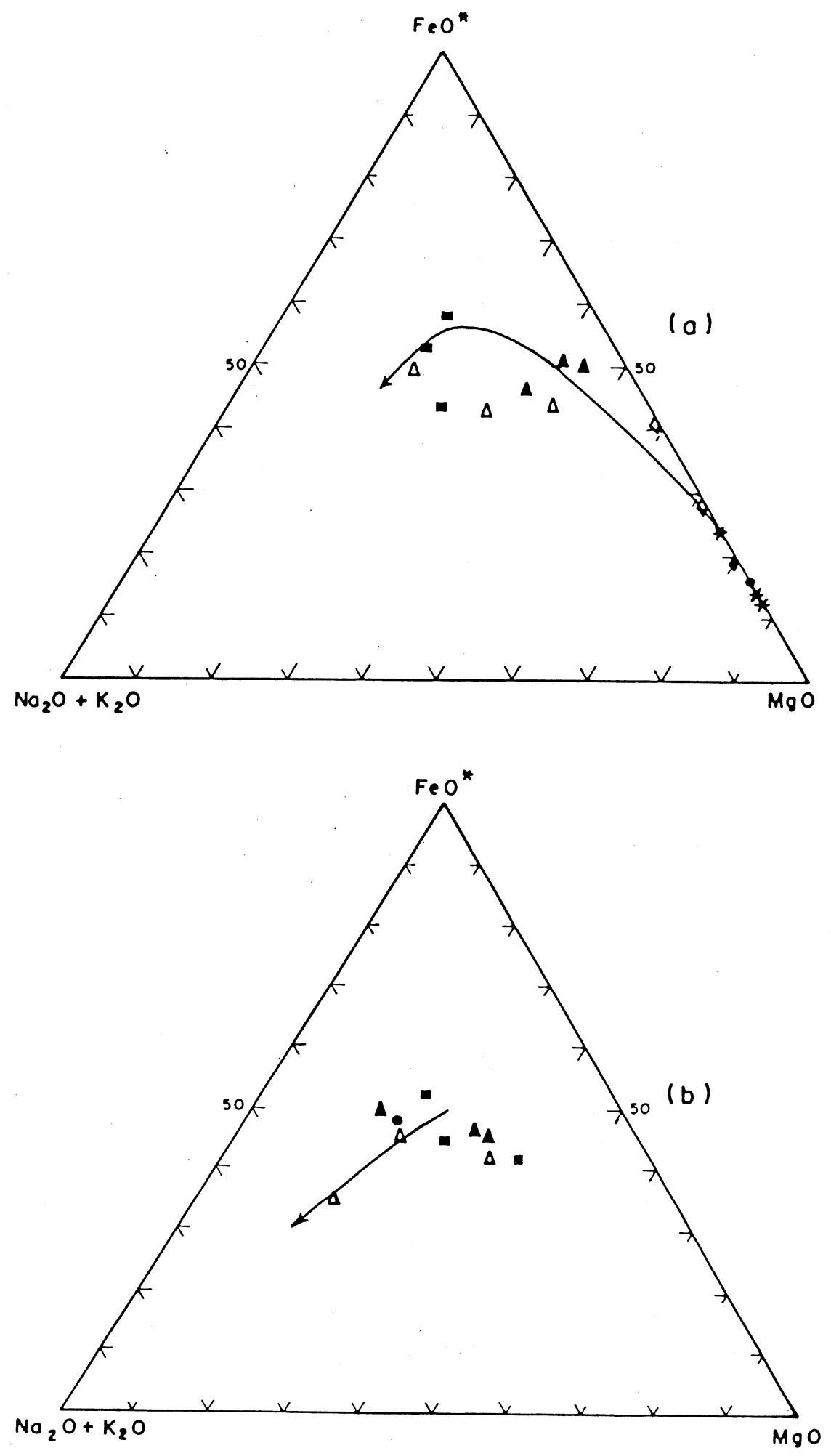

Gambar V.8. Perajahan batuan basalt $(\Delta)$, diabas $(\bullet)$, gabro $(\bullet)$, dunit $(\bullet)$, piroksenit $(*)$, serpentinit $(\diamond)$, dan peridotit piroksen $(\star)$ Meratus - Bobaris.

a : kelompok toleit, b : kelompok kalk alkali. 
kandungan $\mathrm{SiO}_{2}$ antara $42-50 \%, \mathrm{~K}_{2} \mathrm{O}$ dan $\mathrm{TiO}_{2}$ berturut-turut bervariasi antara $0,06-0,85 \%$ dan $0,9-1,29 \%$. Sedangkan angka perbandingan $\mathrm{FeO}^{*} / \mathrm{MgO}$ sekitar 0,5 - 3,5. Data tersebut merupakan ciri dari batuan volkanis yang terbentuk pada lingkungan busur kepulauan seperti yang dikemukakan oleh Miyashiro (1974). Lebih lanjut dikemukakan bahwa pada lingkungan busur kepulauan dapat dicirikan oleh batuan volkanis yang berkomposisi hanya toleit saja, toleit \& kalk alkali, kalk alkali saja, kalk alkali \& alkali, kalk alkali \& toleit \& alkali, atau hanya terdiri dari batuan volkanis yang berkomposisi alkali. Meskipun hanya ketiga jenis yang disebutkan pertama yang seringkali dijumpai. Kesimpulan ini didukung pula oleh kenyataan bahwa kandungan Ni yang rendah (10-50 ppm), angka perbandingan $\mathrm{Ti} / \mathrm{V}$ berkisar antara 10-20 dengan kandungan Ti mencapai 2000-6000 ppm yang juga merupakan salah satu ciri khas dari batuan volkanis lingkungan busur kepulauan (Miyashiro \& Shido, 1975; Shervais, 1982).

- Data isotop yang diperoleh dari hasil analisis 4 (empat) conto batuan mafis (2 gabro dan 2 basalt) dari komplek ofiolit Meratus - Bobaris yang dilakukan oleh Polve (komunikasi pribadi, 1988) ofiolit Meratus - Bobaris menunjukkan angka perbandingan ${ }^{87} \mathrm{Sr} /{ }^{86} \mathrm{Sr}$ berkisar antara $0,7038-0,7041$ dan ${ }^{143} \mathrm{Nd} /{ }^{144} \mathrm{Nd}$ sekitar 0,5129 yang menunjukkan karakter dari batuan berafinitas toleit busur kepulauan, seperti halnya di Mariana dan New Britain (Hawkesworth \& Calsteren, 1984) yang menunjukkan variasi perbandingan isotop ${ }^{87} \mathrm{Sr} /{ }^{86} \mathrm{Sr}$ dan ${ }^{143} \mathrm{Nd} /{ }^{144} \mathrm{Nd}$ berturut-turut antara $0,7035-0,7047$ dan $0,51285-0,5135$.

- Himpunan ofiolit Pegunungan Meratus dan Bobaris dapat digolongkan ke dalam jenis ofiolit kelas I berdasarkan klasifikasi Miyashiro (1974), serupa dengan komplek ofiolit Troodos (Siprus) dan ofiolit Lush's Bight di Newfoundland seperti yang dikemukakan oleh Miyashiro (1974). Ofiolit kelas I dicirikan oleh kehadiran batuan volkanis yang berafinitas dominan toleit, dan sedikit batuan volkanis yang kalk alkali. Ofiolit yang tergolong ke 
dalam kelas I pada umumnya dapat terbentuk di busur kepulauan yang dewasa (mature) maupun tak dewasa (immature), atau pada benua yang stabil (stable continent).

- genesis dari ofiolit busur kepulauan dapat terjadi akibat beberapa hal yaitu

a. Adanya pemekaran dalam skala kecil di busur kepulauan; terjadi suatu celah/split pada kerak samudera, dimana akan terbentuk retas-retas sebagai akibat dari terobosan dari kerak samudera. Proses serupa yang terjadi dengan pembentukan komplek ofiolit Troodos di Siprus (Miyashiro, 1974).

b. Ofiolit busur kepulauan juga dapat merupakan bagian dari kerak samudera yang sudah ada sebelum pembentukan busur kepulauan dimulai, seperti halnya dengan ofiolit yang terdapat di busur-busur kepulauan Yap dan Palau di laut Pilipina, serta ofiolit di Puerto Rico (Miyashiro, 1974).

c. Kemungkinan lainnya adalah terbentuknya akibat pelelehan sebagian (partial melting) dari sebagian mantel yang terbawa dari bagian bawah ke atas akibat penunjaman seperti halnya dengan pembentukan ofiolit dari Mariana Trench (Bloomer \& Hawkins, 1983). 


\section{BAB VI}

\section{DISKUSI DAN SINTESIS}

Sekarang ofiolit sudah merupakan salah satu bagian dari konsep tektonik lempeng terbukti dari banyaknya penelitian yang dilakukan oleh para ahli petrologi dan tektonik dalam kaitannya dengan pembentukan pegunungan ataupun dengan masalah mulajadi kerak samudera. Dimulai dari penyempurnaan mengenai definisi dari istilah ofiolit (terwujud sebagai hasil dari Penrose Field Conference, 1972) hingga masalah mengenai genesis serta penempatan ofiolit pada kedudukan yang terlihat sekarang (dimana ofiolit diketemukan).

Konsep yang menyatakan bahwa proses pembentukan kerak samudera masa kini mempunyai persamaan dengan proses magmatis yang terjadi pada pembentukan ofiolit merupakan stimulator bagi para ahli untuk menciptakan proyek-proyek penelitian khususnya di dasar laut. Diantaranya adalah East Pacific Rise Study Group (1981) dan Deep Sea Drilling Program (DSDP) dari U.S. National Science Foundation. Dari proyek yang disebut terakhir telah diperoleh ribuan conto inti bor dari hampir semua samudera yang terkenal di dunia dan telah dianalisis kimia (Melson et al, 1976; serta beberapa laporan dari setiap leg; dikutip dari Coleman, 1984). Meskipun diakui pula bahwa upaya untuk membandingkan ofiolit dengan kerak samudera dari segi petrologi dan pola kimianya seringkali menemui hambatan akibat proses pengubahan hidrotermal serta pemalihan regional yang seringkali terjadi selama pembentukan ofiolit.

Salah satu aspek penting dalam kaitannya dengan ofiolit adalah usaha dalam menciptakan suatu model tatanan tektonik tertentu sehubungan dengan pembentukan ofiolit. Terdapatnya ofiolit pada beberapa lajur sutur dan jalur-jalur orogen menunjukkan keikutsertaan kerak samudera di dalam kegiatan tektonik yang berkaitan dengan pembentukan pegunungan (Dewey, 1976; Dewey \& Bird, 1971; Moores, 1982; dikutip dari Coleman, 1984).

Ofiolit diketahui dapat terbentuk pada beberapa tatanan tektonik berbeda, 
yaitu pada punggung tengah samudera, cekungan belakang busur, cekungan muka busur, busur-busur kepulauan, dan pada tepian pasif (passive margin) atau cekungan samudera kecil (small ocean basin) yang masing-masing mempunyai karakteristik baik dari segi strukturnya dan dari segi petrologi \& pola kimianya.

Karena ofiolit umumnya terdapat di dalam ataupun sepanjang lajur-lajur sutur menandai adanya benturan benua ataupun adanya akresi, maka umur serta mulajadi/genesis ofiolit merupakan petunjuk penting yang dapat digunakan dalam mempelajari tentang jalur orogen. Begitu juga masalah penempatan ofiolit pada kedudukan sekarang (pada daerah sutur) perlu dipelajari.

Di daerah Karangsambung Utara seperti telah dijelaskan pada bab I juga dijumpai komplek himpunan batuan mafis - ultramafis yang terdapat di daerah melange berumur Kapur Akhir - Tersier Awal (?). Beberapa kesimpulan yang spesifik khususnya dari studi petrologi dan pola kimianya telah dibahas pada bab-bab terdahulu (bab II-IV). Sedangkan beberapa kesimpulan tentang ofiolit Peg. Meratus - Bobaris yang dipilih sebagai pembanding telah dibahas secara khusus dalam bab V. Dalam bab VI ini akan diulas kembali hasil-hasil yang telah disimpulkan pada pembahasan terdahulu, dan akan dibuat suatu sintesis yang menggambarkan tentang genesis ofiolit dari kedua daerah tersebut berikut proses penempatannya berdasarkan atas hasil-hasil tersebut di atas, dilengkapi dengan pengolahan informasi-informasi yang telah terbit ataupun data yang belum diolah /diterbitkan dari daerah kedua daerah tersebut. Pada akhirnya akan dibuat skenario tentang perkembangan dari penyebaran batuan dasar khususnya di $P$. Jawa dan P. Kalimantan bagian timur.

\subsection{Genesis dan penempatan ofiolit Karangsambung Utara}

Himpunan batuan mafis ultramafis daerah penyelidikan terdiri dari himpunan batuan harsburgit yang telah mengalami serpentinisasi, serpentinit, lersolit, gabro (kumulat dan non kumulat), diabas dan basalt berstruktur bantal. Di lapangan himpunan batuan ini memperlihatkan gejala deformasi yang kuat, dan batas antar batuan yang merupakan sesar-sesar sungkup. 
Dari analisis petrografi dan kimia (unsur-unsur utama, jejak, dan UTL) menunjukkan bahwa himpunan batuan tersebut ko genetis, berasal dari magma yang berkomposisi toleit. Batuan volkanisnya memperlihatkan kandungan $\mathrm{K}_{2} \mathrm{O}$ dan $\mathrm{P}_{2} \mathrm{O}_{5}$ rendah, berturut-turut antara 0,1-1\% dan 0,1-0,2\%, $\mathrm{TiO}_{2}$ sekitar 0,3-1,18, dengan angka perbandingan $\mathrm{FeO}^{*} / \mathrm{MgO}$ kurang dari 2 . Karakter kimia lainnya adalah angka perbandingan $\mathrm{Ti} / \mathrm{V}$ berkisar antara 20-50 dengan kandungan $\mathrm{Ti}$ sekitar 2000 - 6500 ppm. Angka perbandingan tersebut dimiliki oleh batuan volkanis yang terbentuk pada lingkungan punggung tengah samudera; ciri tersebut berbeda dengan batuan toleit busur kepulauan yang dicirikan oleh $\mathrm{Ti} / \mathrm{V}$ antara 10-20 ppm dengan kandungan Ti yang relatif lebih kecil yaitu sekitar 2000-6000 ppm (Shervais, 1982). Pola fraksinasi UTL basalt dan diabas mempunyai kesamaan dengan pola fraksinasi UTL serupa yang dimiliki oleh basalt dari berbagai punggung tengah samudera tipe- $\mathrm{N}$ antara lain dari Mid-Atlantic Ridge, Indian Ocean Ridge, dan basalt dari samudera Pasifik (data tersebut dikutip dari Sanders, seperti terlihat pada gambar IV.16). Data isotop ${ }^{87} \mathrm{Sr} /{ }^{86} \mathrm{Sr}$ serta ${ }^{143} \mathrm{Nd} /{ }^{144} \mathrm{Nd}$ menunjukkan nilai berturut-turut antara 0,703218 - 0,704311 dan 0,513073 - 0,513171, diperoleh dari analisis batuan basalt (SL6), diabas (L-14 \& LK-36), dan gabro (ST-7) yang dilakukan oleh Polve (komunikasi pribadi, 1988). Didasarkan kepada data lapangan bahwa masing-masing satuan dibatasi oleh sesar, maka ofiolit daerah ini tergolong jenis ofiolit terpisah-pisah (dismembered Ophiolite), yang juga termasuk ofiolit kelas II menurut klasifikasi Miyashiro yang didasarkan kepada ciri-ciri kimia batuan volkanis.

Umur dari ofiolit daerah penelitian adalah 81-85 juta tahun atau Kapur Akhir/Senonian (berdasarkan pentarikhan umur basalt dan diabas). Melihat kepada data tersebut, dan dikaitkan dengan kedudukan sekarang dimana ofiolit terdapat pada daerah lajur tunjaman jaman Kapur yang ditandai oleh adanya komplek melange, maka disimpulkan bahwa :

- ofiolit daerah penelitian adalah kepingan dari samudera yang terbawa sebagai akibat dari tumbukan antara kerak Samudera Hindia dengan kerak 
benua (Eurasia) pada jaman Kapur Akhir sampai Tersier Awal (?). Proses penunjaman ini dapat dibuktikan dengan adanya anomali magnetik $33 \mathrm{~b}$ di selatan P. Jawa yang terekam dengan kisaran umur 70-82 juta tahun yang menunjukkan bagian dari punggung tengah samudera umur tersebut (Sclater \& Fisher, 1974), umur yang mana lebih kurang sama dengan umur ofiolit daerah penelitian. Dengan demikian dapat diperkirakan bahwa ofiolit disini adalah bagian dari punggung tengah samudera dengan anomali magnetik $33 \mathrm{~b}$ tersebut.

Model penempatan ofiolit daerah Karangsambung Utara di dasarkan atas beberapa kriteria sebagai berikut :

a. Keadaan dilapangan ofiolit menunjukkan adanya urutan tertentu di dalam distribusi batuannya, yaitu berturut-turut (dari selatan ke utara) terdiri atas basalt, diabas, gabro non-kumulat, gabro kumulat, lersolit, dan harsburgit yang telah mengalami serpentinisasi. Batas antar satuan berupa sesar-sesar sungkup.

b. Meskipun sebagian besar batuan yang terdapat di dalam komplek ofiolit telah mengalami deformasi dan ubahan baik akibat proses hidrotermal dan juga pemalihan, tetapi masih dijumpai beberapa batuan yang relatif tidak terdeformasi. Sebagai contoh pada singkapan di Kali Muncar (Seboro) dimana dijumpai basalt dengan struktur bantalnya yang masih jelas, tidak terdeformasi. Hal yang sama juga pada batugamping-rijang di lokasi yang sama, yang merupakan batuan sedimen yang termasuk di dalam komplek ofiolit. Begitu juga dari hasil analisis petrografi menunjukkan bahwa ada conto-conto batuan yang dapat dikatakan relatif tidak mengalami rekristalisasi / metamorfosis. Perlu dijelaskan bahwa hasil analisis petrografi menunjukkan adanya proses malihan fasies seolit dan fasies sekis hijau disamping proses ubahan hidrotermal. Selain daripada itu, di daerah ini juga diketemukan batuan malihan sekis amfibolit. Dengan data tersebut terlihat adanya suatu urutan proses malihan dari fasies seolit, sekis hijau, dan fasies 
amfibolit.

c. Hasil yang diperoleh dari penelitian ini bahwa ofiolit daerah ini berafinitas toleit yang merupakan bagian dari punggung tengah samudera berumur Kapur Akhir / Senonian.

Dari ketiga hal tersebut maka disimpulkan penempatan ofiolit Karangsambung Utara terjadi akibat tercuatnya kepingan-kepingan punggung tengah samudera yang merupakan bagian dari kerak samudera (Samudera Hindia) ke atas tepian kerak benua Eurasia pada akhir proses penunjaman. Proses penempatan terjadi lebih kurang pada jaman Kapur Akhir - Tersier Awal / Paleosen (90-70 juta tahun yang lalu). Model genesis dan penempatan dari ofiolit Karangsambung Utara dapat dilihat pada Gambar VI.1, Gambar VI.3a. serta Gambar VI.4. menggambarkan kedudukan pada waktu sekarang.

\subsection{Genesis dan penempatan ofiolit Peg, Meratus - Bobaris.}

Ofiolit Meratus - Bobaris dipilih sebagai studi perbandingan mengingat adanya hubungan dalam hal tatanan tektonik regionalnya. Pembahasan berikut beberapa kesimpulan mengenai ofiolit daerah ini dapat dilihat pada bab V. Pada sub bab ini akan didiskusikan beberapa kesimpulan yang telah diperoleh, dilengkapi dengan beberapa hipotese yang telah ada; khususnya mengenai ofiolit daerah Meratus-Bobaris maka akan dibuat model genesis berikut mekanisme penempatan pada kedudukan sekarang. Ofiolit Meratus - Bobaris terdiri dari basalt, diabas, gabro, dunit, peridotit piroksen, piroksenit (Burgath, 1986, komunikasi pribadi; Sikumbang, 1986). Berdasarkan asosiasi himpunan batuannya, ofiolit daerah ini dapat tergolong ke dalam ofiolit tidak lengkap (incomplete ophiolite).

Hasil analisis kimia menunjukkan bahwa ofiolit daerah ini batuan volkanisnya terdiri dari dua tipe, yaitu batuan volkanis yang berafinitas toleit dan yang kalk alkali. Kedua tipe batuan volkanis ini juga memperlihatkan beberapa karakteristik kimia tertentu seperti Si02 antara 42-50\%, K20 dan Ti02 masing-masing bervariasi antara $0,06-0,85 \%$ dan $0,9-1,29 \%$. Sedangkan angka 


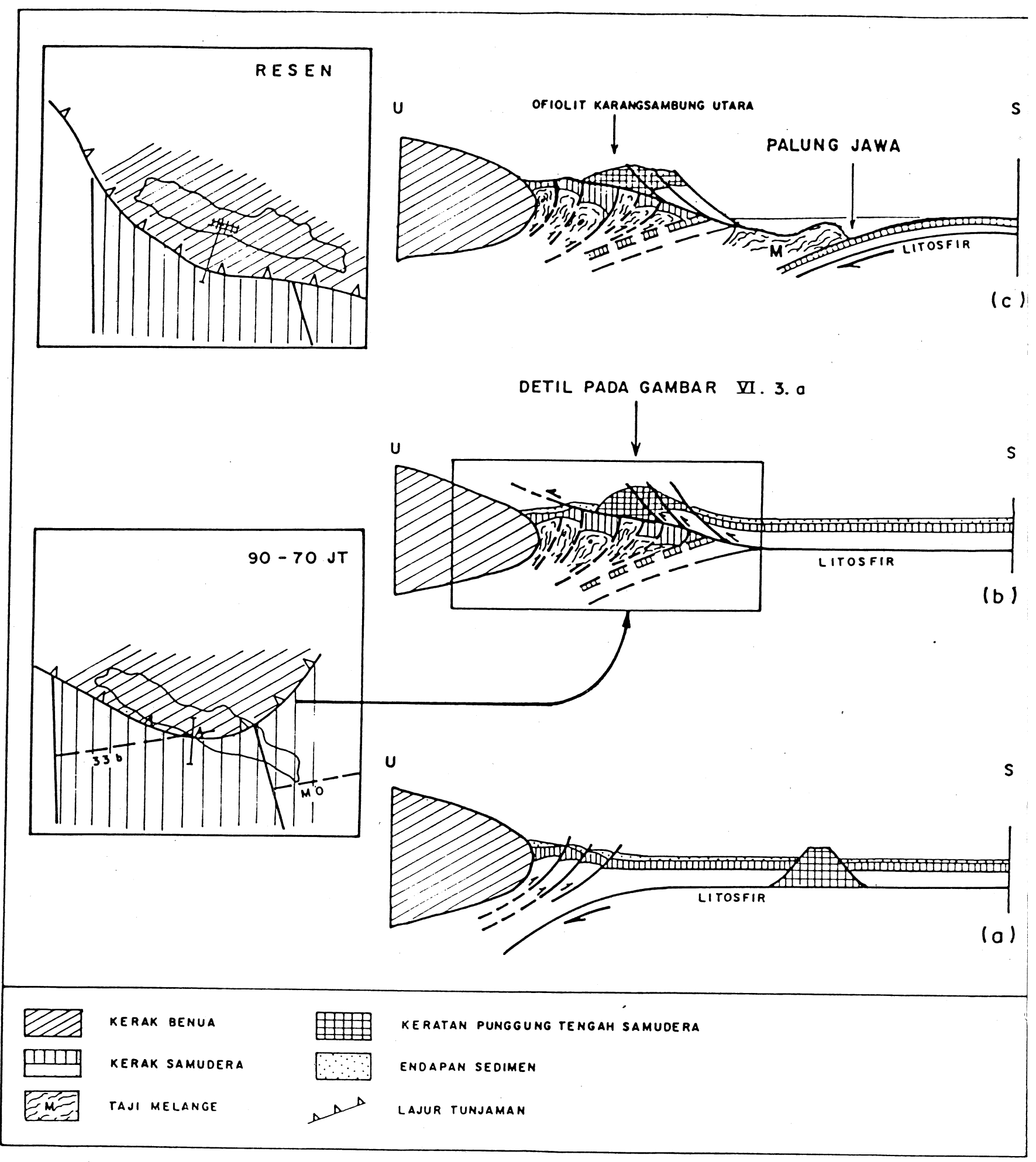

Gambar VI.1. Skenario genesis dan penempatan ofiolit Karangsambung Utara 
perbandingan $\mathrm{FeO}^{*} / \mathrm{MgO}$ dan $\mathrm{Ti} / \mathrm{V}$ berturut-turut antara 0,5-3,5 dan 10-20, kandungan Ni cukup rendah yaitu antara $10-50 \mathrm{ppm}$. Data tersebut merupakan ciri dari batuan volkanis yang terbentuk di lingkungan busur kepulauan (Miyashiro, 1974). Lebih lanjut dikemukakan bahwa pada lingkungan busur kepulauan dapat diketemukan batuan volkanis berkomposisi toleit, kalk alkali atau alkali saja, toleit \& kalk alkali, toleit \& kalk alkali \& alkali, kalk alkali \& alkali. Data isotop yang diperoleh dari analisis 4 (empat) conto batuan ( 2 gabro dan 2 basalt) memberikan hasil 87Sr/86Sr = 0,7038-0,7041, sedangkan 143Nd/144Nd sekitar 0,5129 (Polve, 1988; komunikasi pribadi), yang menunjukkan karakter batuan volkanis dari busur kepulauan seperti halnya yang diketemukan di Mariana dan New Britain (Hawkesworth \& Calsteren, 1984), yang mempunyai variasi perbandingan isotop $87 \mathrm{Sr} / 86 \mathrm{Sr}=0,7035-0,7047,143 \mathrm{Nd} / 144 \mathrm{Nd}=0,51285-0,5135$. Selanjutnya dapat disimpulkan bahwa ofiolit daerah ini dapat digolongkan ke dalam jenis ofiolit kelas I menurut Miyashiro. Jenis ofiolit ini ditandai antara lain oleh adanya batuan volkanis yang berkomposisi toleit dan kalk alkali.

Genesis ofiolit yang terbentuk di lingkungan busur kepulauan dapat terjadi akibat beberapa hal yaitu akibat adanya celah (split) pada daerah busur kepulauan yang menimbulkan adanya pusat pemekaran kecil dimana akan terjadi penerobosan kerak samudera akibat desakan fragmen litosfir. Contoh yang terkenal ofiolit tipe ini adalah ofiolit Troodos di Siprus (Miyashiro, 1974). Selain itu ofiolit busur kepulauan juga dapat terjadi akibat pelelehan sebagian dari bagian mantel yang terbawa akibat proses tunjaman, dan dapat pula merupakan keratan dari kerak samudera yang telah ada. Contoh dari dua tipe ofiolit yang disebut terakhir berturut-turut adalah ofiolit yang terdapat di busur kepulauan Yap dan Palau di Pilipina, dan ofiolit Mariana yang juga di Pilipina.

Dari beberapa model genesis yang ada serta didasarkan atas beberapa kriteria sebagai berikut :

a. Hipotese mengenai penempatan ofiolit Meratus - Bobaris yang dikemukakan oleh beberapa penulis diantaranya Priyomarsono (1985), Sikumbang (1986), 
Situmorang (1987) yang mana disimpulkan bahwa penempatan ofiolit pada kedudukan sekarang adalah karena pencuatan lemping-lemping kerak samudera pada waktu terjadi tumbukan antara kerak benua Eurasia bagian timur (kerak Sunda) dengan kerak samudera Pasifik. Informasi terbaru mengenai penempatan ofiolit daerah ini diperoleh dari Situmorang (1987) yang mengemukakan bahwa data analisis gaya berat menunjukkan bahwa batuan ultrabasa (yang termasuk ke dalam komplek ofiolit) yang terdapat di Peg. Meratus mempunyai ketebalan lebih kurang 300-350 meter. Lemping ultrabasa ini menebal ke arah tenggara.

b. Hasil analisis kimia yang menunjukkan bahwa ofiolit daerah ini adalah ofiolit busur kepulauan yang mempunyai dua jenis batuan volkanis dari tipe toleit (dominan) dan kalk alkali. Adanya dua macam batuan volkanis dimana batuan yang berkomposisi toleit lebih dominan, berarti lingkungan pembentukannya masih pada lingkungan yang lebih banyak dipengaruhi oleh keikutsertaan kerak samudera. Hal tersebut dapat terjadi pada busur kepulauan tak dewasa (immature island arc), atau busur kepulauan yang masih dibawah permukaan laut (Miyashiro, 1974).

Dari kriteria tersebut diatas maka disimpulkan bahwa ofiolit daerah ini terbentuk di busur kepulauan yang tak dewasa, akibat proses pelelehan sebagian dari keratan mantel yang terbawa pada waktu proses penunjaman. Proses pembentukan ini terjadi pada jaman Kapur Awal (120-95 juta tahun yang lalu), dijelaskan dengan hasil pentarikhan umur batuan plagiogranit dan meta diabas yang mewakili komplek ofolit menunjukkan umur berturut-turut $116 \mathrm{jt}$. (Priyomarsono,1985) dan 96 jt. (Sikumbang, 1986), sehingga akan dihasilkan batuan volkanis yang berkomposisi toleit dan kalk alkali. Keratan / lemping busur kepulauan ini kemudian tercuatkan pada akhir dari proses tunjaman yang merupakan benturan dari kerak benua (Eurasia bagian timur) dengan kerak samudera Pasifik di sebelah timur / tenggara (lihat Gambar VI.2). Perlu dijelaskan disini bahwa gambar VI.2d. dimodifikasi dari Yuwono (1987). Lebih lanjut dapat 


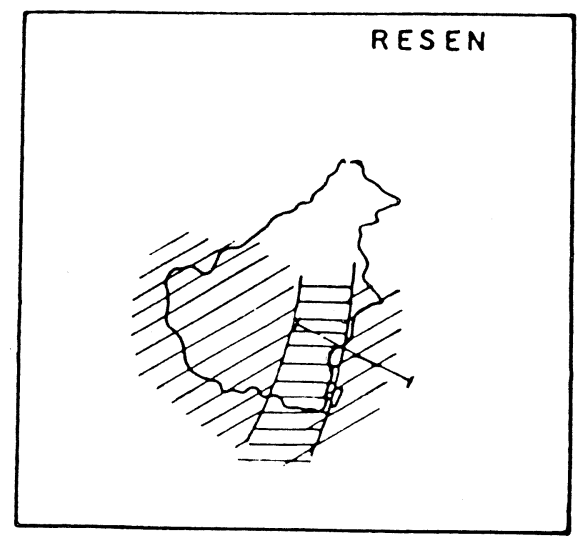

BARAT LAUT

TENGGARA

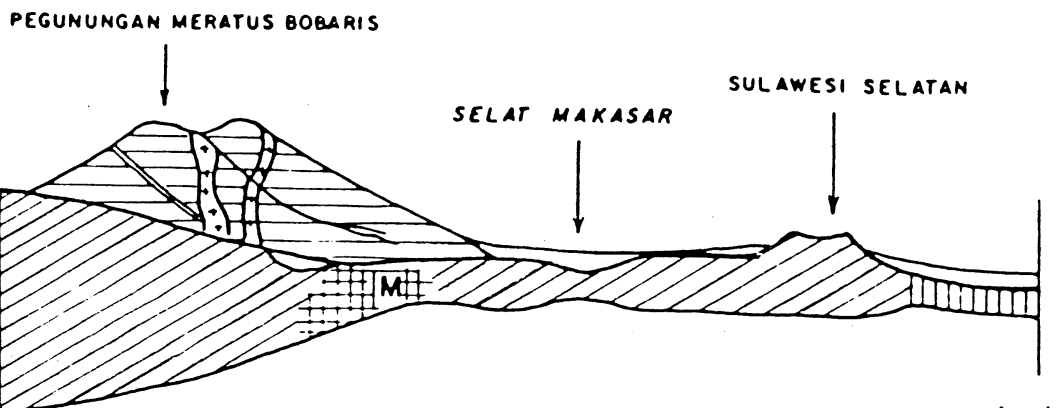

(d)
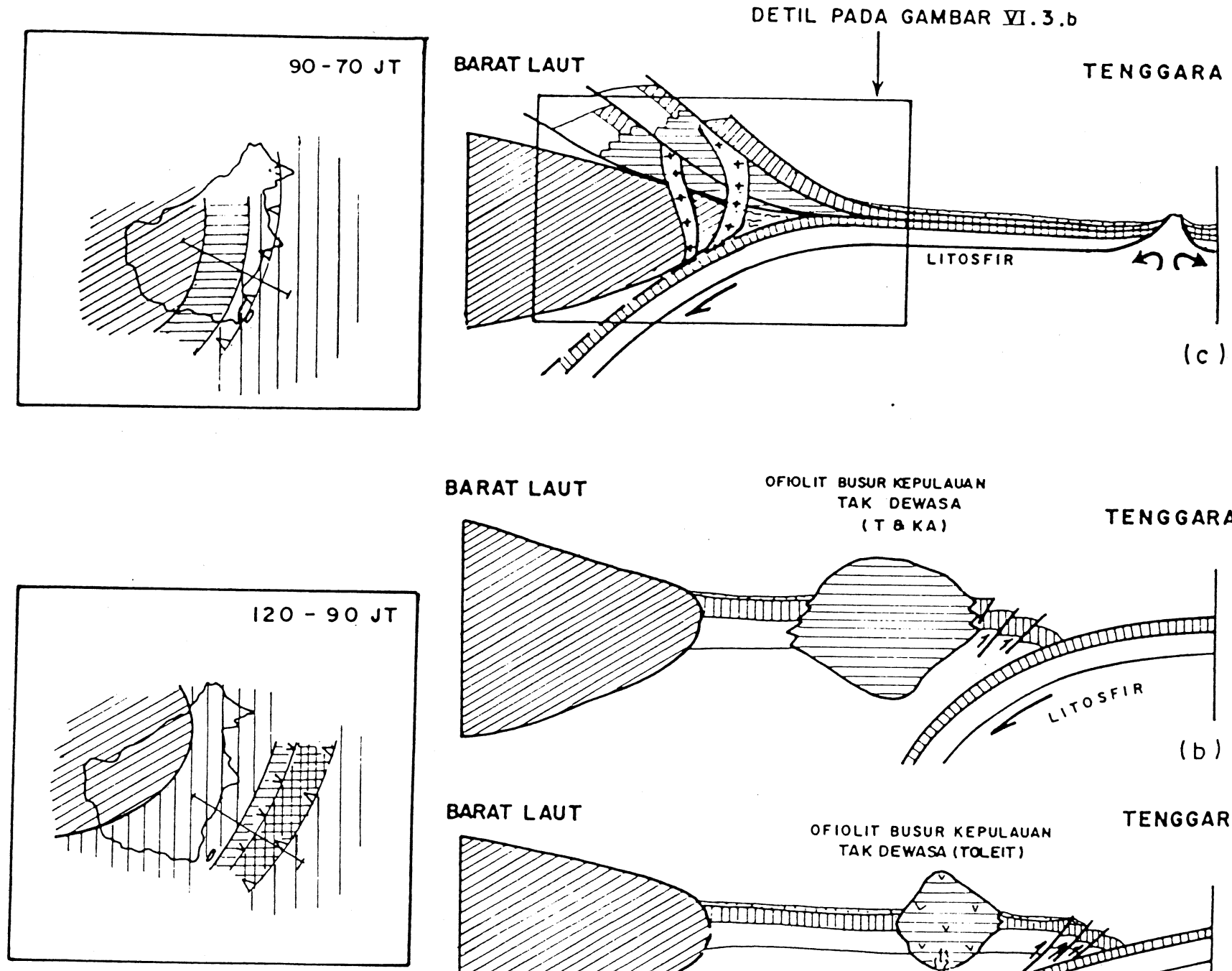

BARAT LAUT

OFHLIT BUSUR KEPULAUAN

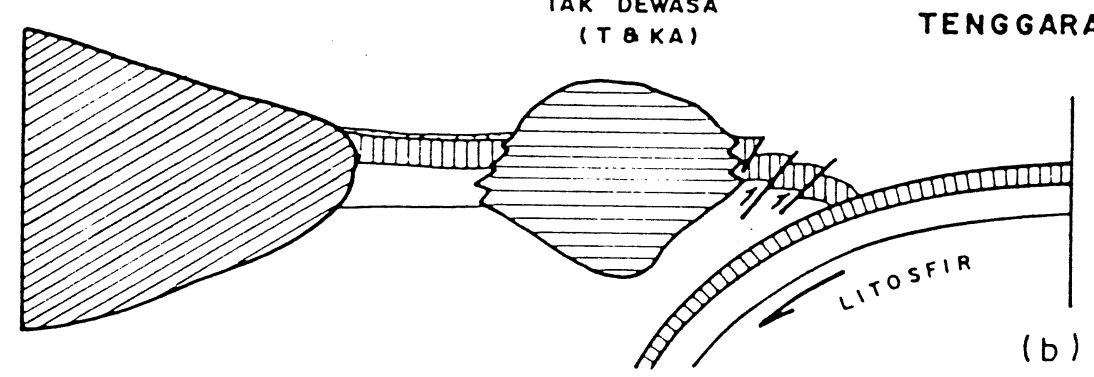

BARAT LAUT

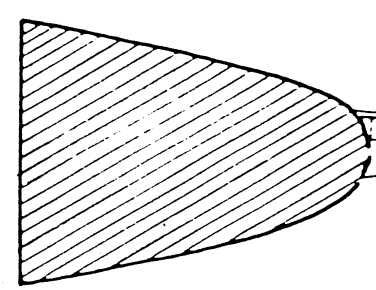

OFIOLIT BUSUR KEPULAUAN

TENGGARA

(b) TAK DEWASA (TOEIT)

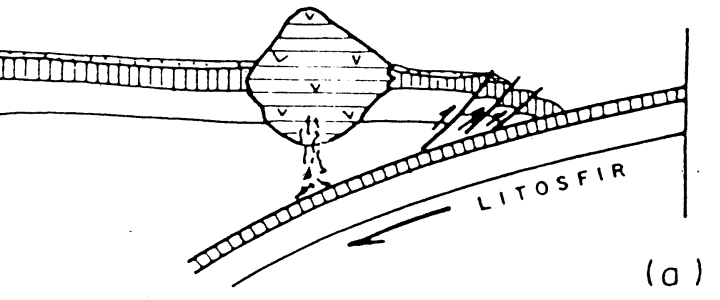

EAPEA TAJIMELANGE

Gambar VI.2. Skenario genesis dan penempatan ofiolit Peg. Meratus-Bobaris. 
dilihat pada Gambar VI.3b dimana ditunjukkan detil dari penempatan ofiolit daerah ini yang dengan jelas terlihat perbedaannya dengan penempatan ofiolit Karangsambung Utara (Gambar VI.3a).

\subsection{Sintesis}

Sintesis akan menggambarkan perkembangan dari distribusi atau penyebaran batuan dasar khususnya di P.Jawa dan P. Kalimantan Timur jaman Kapur AwalKapur Akhir (lihat Gambar VI.5).

- Kala Barremian-Cenomanian (120-90 jt). Pada jaman ini sebagian dari daratan Malaya, Indochina, Sumatera, P. Jawa, P. Kalimantan serta Sulawesi bagian barat masih menyatu, merupakan bagian tenggara dari benua Asia (Eurasia) yang dikelilingi oleh kerak samudera Neo-Tethys purba (Audley-Charles, 1976; Sikumbang, 1986). Akibat dari pergerakan kerak samudera di bagian selatan ke arah lebih kurang ke utara, maka kerak samudera ini akan menumbuk kerak benua Eurasia dan menyebabkan tunjaman kerak samudera ke bawah kerak benua. Sebagai hasilnya berupa lajur tunjaman dijumpai di selatan pulau Jawa dan di daerah Kalimantan Tenggara / Kalimantan Timur (lihat Gambar VI.5a). Di wilayah Indonesia bagian Timur kala itu terjadi pembentukan ofiolit di busur kepulauan tak dewasa yang merupakan hasil pelelehan sebagian dari keratan mantel yang terbawa akibat proses penujaman dari kerak samudera Pasifik dengan kerak benua Eurasia bagian timur/tenggara. Lajur tunjaman dibuktikan dengan adanya anomali magnetik M O (Lapouille et al., 1985) dengan kisaran umur 82-112 jt. Ofiolit inilah yang diduga tercuatkan pada proses penunjaman berikutnya.

- $\quad$ Kapur Akhir (Campanian-Maestrichtian) atau 90-70 jt. : Pada jaman ini proses penunjaman tetap berlangsung dengan pusat pemekaran yang lebih muda. Adanya pusat pemekaran ini ditunjukkan dengan diketemukannya keratan punggung tengah samudera di selatan P. Jawa dengan anomali magnetik 33b yang mempunyai kisaran umur 70-82 jt (Sclater \& Fischer, 


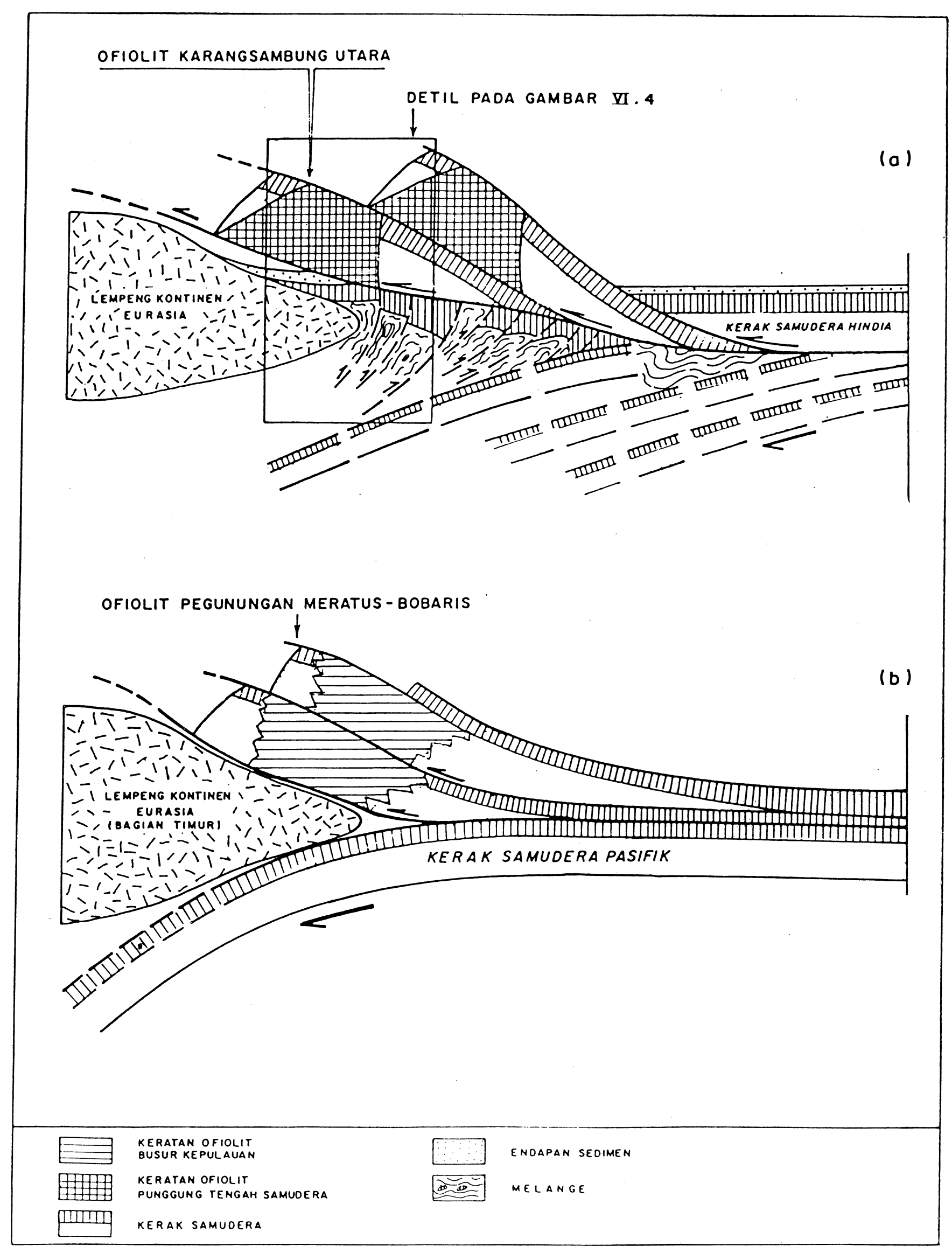

Gambar VI.3. Gambar detil penempatan ofiolit Karangsambung Utara (a) dan ofiolit Peg. Meratus-Bobaris (b). 


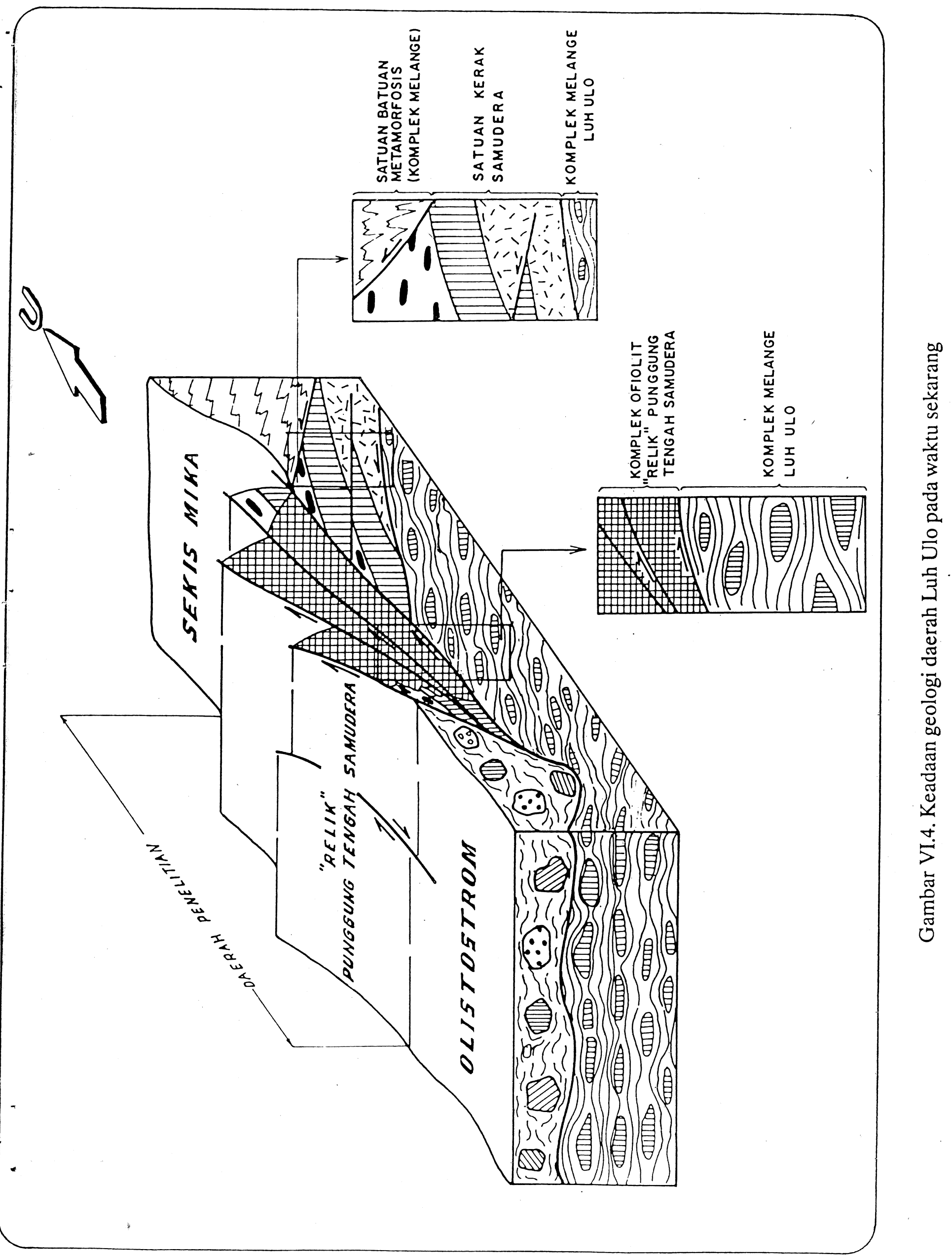


1974). Sedangkan hasil proses tunjaman ini berupa komplek melange, yang sekarang dijumpai di tiga daerah di P. Jawa yaitu di Ciletuh, Jawa Barat, Luh Ulo dan Pegunungan Jiwo di Jawa Tengah. Khususnya di daerah Luh Ulo dimana penelitian ini dilakukan, tersingkap ofiolit yang merupakan keratan dari punggung tengah samudera jaman Kapur Akhir/Campanian. Sedangkan di Kalimantan Timur proses tunjaman jaman Kapur berakhir dengan tercuatkannya ofiolit busur kepulauan ke tepian benua Eurasia bagian timur/ tenggara akibat benturan kerak benua tersebut dengan kerak samudera Pasifik.

- $\quad$ Pada Kala Resen distribusi dari batuan dasar di wilayah Indonesia Timur khususnya di P. Jawa dan P. Kalimantan Timur dapat dilihat pada Gambar VI.5a. 


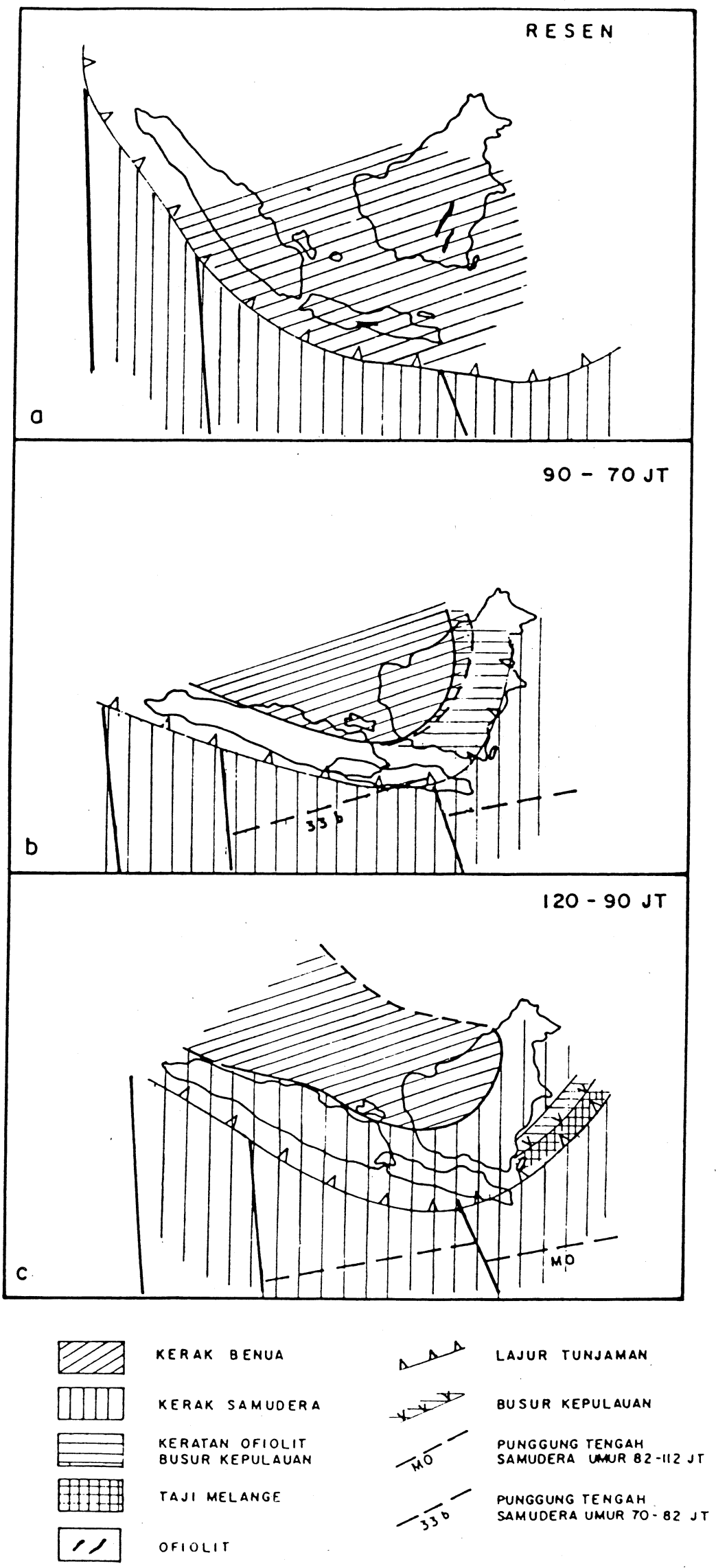

Gambar VI.5. Skenario perkembangan dari penyebaran batuan dasar (Pulau Jawa dan Kalimantan Timur). 


\section{DAFTAR PUSTAKA}

1. Abbotts, I.L., Masirah (Oman) ophiolite sheeted dykes and pillow lavas : geochemical evidence of the former ocean ridge environment. Lithos, vol.14, $283-294$ (1981).

2. Acheche, J., Courtillot, V., and Besse, J., Paleomagnetic constrains on the Late Cretaceous and Cenozoic tectonics of Southeast Asia. Earth. Planet. Sci. Lett., vol.63, 123-136 (1983).

3. Alabaster, T., Pearce, J.A., and Malpas, J., The volcanic stratigraphy and petrogenesis of the Oman ophiolite complex. Contrib. Mineral. Petrol., vol. 81, 168 - 183 (1982).

4. Allegre, C.J., Montigny, R., Bottinga, Y., Cortege ophiolitique et cortege oceanique, geochimie comparee et mode de genese. B.S.G.F., 7, XV, 5 - 6, 461 -477 (1973).

5. ------, Motigny, R., Bottinga, Y., Cortege ophiolitique et cortege oceanique, geochimie comparee et mode de genese . Bull. Soc. Geol. France 7, vol.XV, $461-477$ (1973).

6. ------, Noiret, G., Trace element geochemistry in Inzecca Ophiolite Complex (in prep.).

7. -.----, Trace element systematics in ophiolite suites. (in prep.).

8. Audley-Charles, M.G., Mesozoic evolution of the margins of Tethys in Indonesia and the Phillipines. Proc. Indonesian Petrol. 6th conv., vol. 2, 25 52 (1976).

9. Bebien, J., Ohnenstetter, D., Ohnenstetter, M., Paupy A., Rocci, G., The role of hypopissal magmatic rocks in our understanding of ophiolite models. 
Petrologie, t.1, no.2, 157 - 168 (1975).

10. Beccaluva, L., Ohnenstetter, D., Ohnenstetter, M., and Venturelli, G., The trace element geochemistry of Corsican ophiolite. Contrib. Mineral. Petrol., vol.64, 11 - 31 (1977).

11. ------, Ohnenstetter, D., and Ohnenstetter, M., Geochemical discrimination between ocean-floor and island-arc tholeiites-application to some ophiolites. Can. Jour. Earth Sci., vol.16, 1874 - 1882 (1979).

12. Bloomer, S.H. and Hawkins, J.W., Gabbroic and ultramafic rocks from Mariana Trench : an island arc ophiolite. In Hayes, D.E. (ed). The tectonic and geologic evolution of Southeast Asian seas and islands, part I, 294-317 (1983).

13. Bodinier, J.L., Dupuy, C., Dostal, J., Carme, F., Geochemistry of ophiolites from the Chamrousse complex (Belledonne massif, Alps). Contrib. Mineral. Petrol., vol. 78, 379 - 388 (1981).

14. Boudier, F., Coleman, R.G., Cross section through the peridotite in the Samail ophiolite, Southeastern Oman Mountains. Jour. Geophys. Res., vọl.86, no.B 4, 2573-2592 (1981).

15. Casey, J.F., Dewey, J.F., Initiation of Subduction zones along transform and accreting plate boundaries, triple-junction evolution, and fore arc spreading centres-implications for ophiolitic geology and obduction. In Gass, I.G., Lippard, S.T., and Shelton A.W. (eds). Ophiolites and Oceanic Lithosphere. Geol. Soc. Spec. Publ., no. 13, 269 - 290 (1984).

16. Clifford, J.A., William, P.I., David, L.J., Saleeby, J.B., The ophiolitic of North Fork terrace in the Salmon River region, Central Klamath Mountains, California. Geol. Soc. Amer. Bull., vol.94, 236 - 252 (1983).

17. Coish, R.A., Hickey, R., Frey, F.A., Rare earth element geochemistry of the Betts Cove ophiolite, Newfoundland : complexities in ophiolite formation. 
Geochim. Cosmochim. Acta, vol.46, 2117 - 2134 (1982).

18. Coleman, R.G., Ophiolites : Ancient Oceanic Lithosphere ?. Minerals and Rocks, vol.12, 229 (1977).

19. ------, Tectonic setting for ophiolite obdution in Oman. Jour. Geophys. Res., vol.86, no. B 4, 2497 - 2508 (1981).

20. -----, The diversity of ophiolite. In Zwart, H.J., Hartman, P., and Tobi, A.C. (eds). Ophiolites and ultramafic rocks. Jour. of the Royal Geological and Mining Soc. Netherland. Spec. Iss. vol. 63, no. 2, 141-150 (1984).

21. Curray, J.R., Moore, D.G., Lawver, L.A.. Emmel, F.J., Raitt, R.W., Henry, M., Kieckhefer, R., Tectonics of the Andaman Sea and Burma. In Watkins, Joel, S., et al (eds). Geological and geophysical investigations of the continental margins. AAPG Memoir, vol.29, 189-198 (1979).

22. Davies, Phillip, R., Tertiary structural evolution and related hydrocarbon occurences, North Sumatra Basin. Proc. Indonesian Petrol. Ass. 14th ann. conv., vol.1, 19- 49 (1984).

23. Davis, H.L., Papuan ultramafic belt. XXIII Int. Geol. Cong., vol.1, 209 - 220 (1968).

24. -----, and Jaques, A.L., Emplacement of ophiolites in Papua New Guinea. In Gass, I.G., Lippard, S.J., and Shelton, A.W. (eds). Ophiolites and Oceanic Lithosphere, Geol. Soc. Special Publ., no.13, Blackwell Scientific Publication, 341 - 357, (1984).

25. de Coster, G.L., The Geology of the Central and South Sumatran basins. Proc. Indonesian Petrol. Ass., 5th ann. conv., 77 - 110 (1975).

26. Dewey, J.F., Mountain Belts and the New Global Tectonics. Jour. Geophy. Res., vol.75, no.14, 257 - 279, (1970). 
27. -----, Ophiolite obduction. Tectonophysics, vol.31, 93 - 120 (1975).

28. ------, and Bird, J.M., Origin and emplacement of the ophiolite suite : Appalachian ophiolites in Newfoundland. Jour. Geophys. Res., vol.76, no.14, 3179 - 3206 (1976).

29. Dickinson, W.R., Tectono-stratigraphic evolution of subduction-controlled sedimentary assemblages. In Talwani, M., and Pitman III, W.C. (eds). Island Arcs Deep Sea Trenches and Back Arc Basins. Maurice Ewing Series 1, 3340, (1977).

30. Evans, C.A., Hawkins, J.W., and Moore, G.F., Petrology and geochemistry of ophiolitic and associated volcanic rocks on the Talaud Islands, Molucca Collision Zone, Northeast Indonesia, Petrology and geochemistry. In Hilde, T.W.C., et al. (eds): Geodyn. Ser., vol.11, 159- 172 (1983).

31. Evensen, N.M., Hamilton, P.J., and O'Nions, R.K., Rare- earth abundances in chondritic meteorites. Geochim. Cosmochim. Acta, vol.42, 1199 - 1212 (1977).

32. Floyd, P.A., and Winchester, J.A., Magma type and tectonic setting discrimination using immobile elements. Earth Planet. Sci. Lett., vol.27, 211 218 (1975).

33. Frey, F.A., and Haskin, L., Rare earths in oceanic basalts. Jour. Geophys. Res., vol.69, no.4, 775 - 780 (1964).

34. ------, Bryan, W.B., Thompson, G., Atlantic ocean floor : Geochemistry and petrology of basalts from legs 2 and 3 of the Deep - Sea Drilling Project. Jour. Geophys. Res., vol.79, no.35, 5507 - 5527 (1974).

35. -----, Dickey, J.S., Thompson, G., Bryan, W.B., Davies, H.L., Evidence for heterogeneous primary MORB and mantle source, NW Indian ocean. Contrib. Mineral. Petrol., vol.74, 387 - 402 (1980). 
36. Gast, P.W., Trace element fractionation and the origin of tholeiitic and alkaline magma types. Geochim. Cosmochim. Acta, vol.32, 1057 - 1087 (1968).

37. Ghent, E.D., and Stout, M.Z., Metamorphism at the Samail ophiolite, Southeastern Oman Mountains. Jour. Geophys. Res., vol.86, no.B 4, 2557 2571 (1981).

38 Girardeau, J., Tectonic structures related to thrusting of ophiolitic complexes : the White Hills peridotite, Newfoundland. Can. Jour. Earth. Sci, vol.19, 709 722 (1982).

39. -----, Mercier, J.C.C., and Wang Xibin, Petrology of the mafic rocks of the Xigaze ophiolite, Tibet. Contrib. Mineral. Petrol., vol.90, 309 - 321 (1985).

40. Girardi, A.A.V., and Ulbrich, H.H.G.J., Origin and evolution of the Pien mafic-ultramafic complex, Southern Brazil. Jour. of Geology, vol.88, no.3, 251 -269 (1980).

41. Hall, R., Ophiolite emplacement and the evolution of the Taurus suture zone, Southeastern Turkey. Geol. Soc. Amer. Bull., vol.87, 1078 - 1088 (1976).

42. -------, Ophiolites : Figments of Oceanic Lithosphere. In Gass, I.G., Lippard, S.J., and Shelton, A.W. (eds). Ophiolites and Oceanic Lithosphere. Geol. Soc. Spec. Publ., no.13, Blackwell Scientific Publications, 393 - 403 (1984).

43. Haile, N.S., Elhinny, M.W., Dougall. I., Paleomegnetic data and radiometric ages from the Cretaceous of West Kalimantan (Borneo), and their significance in interpreting regional structure. Jour. Geol. Soc., vol. 133, 133-144 (1977).

44. Hajash, Jr., A., Rare earth element abundances and distribution patterns in hydrothermally altered basalt : Experimental results. Contrib. Mineral. Petrol., vol.85, 409 - 412 (1984).

45. Hamilton, W., Subduction in the Indonesian Region. In Talwani, M., and 
Pitman III, W.C. (eds). Island Arcs Deep Sea Trenches and Back Arc Basins. Maurice Ewing Series 1, 15 - 31 (1977).

46. ------, Tectonics of the Indonesian Region. Geol. Surv. Prof. Paper 1078 (1980).

47. -------, Convergent-plate tectonics viewed from the Indonesian Region. (in prep.).

48. Hawkesworth, C.J., and van Calsteren, P.W.C., Radiogenic isotopes-some geological applications. In P. Henderson (ed). Development in Geochemistry, vol.2, 375-421 (1984).

49. Hehuwat, F.H.A., An overview of some Indonesian melange complexes - A contribution to the geology of melange. Memoir. Geol. Soc. China, no.7, 283 - 300 (1986). 48. Hellman, P., L., Smith., Raymond, E., and Henderson, P., The mobility of the rare earth elements : Evidence and implications from selected terrains affected by burial metamorphism. Contrib. Mineral. Petrol., vol. 71, 23 - 44 (1979).

50. Helman, P.L., Smith, Raymond, E. and Henderson, P., The Mobility of the rare earth elements : Evidence and implications from selected terrains affected by burial metamorphism. Contrib. Mineral. Petrol., vol. 71, 23-44 (1979).

51. Henderson, P., General Geochemical properties and abundances of the REE, In P. Henderson (ed). Development in Geochemistry, vol.2, 1 - 29 (1984).

52. -------, and Pankhurst, R.J., Mass-Spectrometric isotope dilution analysis. In P. Henderson (ed). Development in Geochemistry, vol.2, 467 - 495, (1984).

53. Hertogen, J., Janssens, M.J., Palme, H., Trace elements in ocean ridge basalt glasses : implicatios for fractionations during mantle evolution and petrogenesis. Geochim. Cosmochim. Acta, vol. 44, 2125 - 2143 (1980). 
54. Himmelberg, G.R., and Loney, R.A., Petrology of ultramafic and gabbroic rocks of the Canyon Mountain ophiolite, Oregon. Amer. Jour. Sci. vol.280 A, Part I, 232 - 268 (1980).

55. Holcombe, C.J., How rigid are the lithospheric plates ? Fault and Shear rotation in Southeast Asia. Jour. Geol. Soc. London, vol.134, 325-342 (1977).

56. Hooker, P.J., O'Nions, R.K., and Pankhurst, R.J., Determination of rare earth elements in USGS standard rocks by mixed - solvent ion exchange and mass spektrometric isotope dilution. Chem. Geol., vol.16, 189 - 196 (1975).

57. Hopson, C.A., Coleman, R.G., Gregory, R.T., Pallister, J.S., and Bailey, E.H., Geologic section through the Samail ophiolite and associated rocks along a Muscat - Ibra Transect, Southeastern Oman Mountains. Jour. of Geophys. Res., vol.86, no.84, 2527 - 2544 (1981).

58. Hutchison, C.S., Ophiolite in Southeast Asia. Geol. Soc. Amer. Bull., 797 - 806 (1975).

59. Ishiwatari, A., Igneous petrogenesis of the Yakuno ophiolite (Japan) in the context of the diversity of ophiolites. Contrib. Mineral. Petrol., vol.89, 155 - 167 (1985).

60. Jahn, Borming., Mid-ocean ridge or marginal basin origin of the East Taiwan ophiolite : Chemical and isotopic evidence. Contrib. Mineral. Petrol., vol.92, 194 - 206 (1986).

61. Jakes, P., and Gill, J., Rare earth elements and the island arc tholeiitic series. Earth. Planet. Sci. Lett., vol.9, 17 - 28 (1970).

62. Jaques, A.L., Chappell, B.W., Petrology and trace element geochemistry of the Papuan Ultramafic belt. Contrib. Mineral. Petrol.,vol.75, 55 - 70 (1980).

63. ------, Petrology and petrogenesis of cumulate peridotites and gabbros from 
the Marum ophiolite complex. Northern Papua New Guinea. Jour. Petrol., vol.22, Part 1, 1 - 40 (1981).

64. Kay, R.W., Hubbard, N.J., and Gast, P.W., Chemical characteristics and origin of oceanic ridges volcanic rocks. Jour. Geophys. Res., vol.75, no.8, 1585 - 1613 (1970).

65. -------, Senechal, R.G., The Rare earth geochemistry of the Troodos ophiolites complex. Jour. Geophys. Res., vol.81, no.5, 964 - 970 (1976).

66. ------, Trace element in ocean ridge basalts. Earth. Planet. Sci. Lett., vol.38, 95 -116 (1978).

67. Ketner, K.B., Kastowo, Modjo, S., Naeser, C.W., Obradovich, J.D., Robinson, K., Suptandar, T., and Wikarno. Pre-Eocene rocks of Java, Indonesia. Jour. Res. U.S. Geol. Surv., vol.5, no.5, 605 - 614 (1976).

68. Kirby, G.A. The petrology and geochemistry of dykes of the Lizard ophiolite complex. Cornwall. J. Geol. Soc. London., vol.141, 53 - 59 (1984).

69. Kundig, E., Geology and ophiolite problems of East Celebes. Konink. Ned. Geol. Mijnb. Gen. Verh. Geol. Serie, vol.16, 210 - 235 (1956).

70. Kuno, H., Differention of Basalt Magmas. In Hess, H.H. (ed). BASALT : The Poldevaart treatise on rock of basaltic composition, vol.2., John Willey \& Sons, Inc., 623 - 688 (1968).

71. Langmuir, C.H., and Bender, J.F., The geochemistry of oceanic basalts in the vicinity of transform faults : observations and implications. Earth. Planet. Sci. Lett., vol.69, 107 - 127 (1984).

72. Lapouille, A., Haryono, H., Larue, M., Pramomijoyo, S., Lardy, M., Age and origin of the seafloor of the Banda Sea (Eastern Indonesia), Oceanologica Acta, vol.8, no.4, 379-389 (1985). 
73. Leterrier, J., Maury, R.C., Thonnon, P., Girard, D., and Marchal, M., Clinopyroxene composition as a method of identification of magmatic affinities of paleo-volcanic series. Earth. Planet. Sci. Lett., vol.59, 139-154, (1982).

74. Loubet, M., Allegre, C.J., Analyse des terres rares dans les echantillons geologique par dilution isotopique et spectrometrie de masse. Application a la distinction entre carbonatites et calcaires. Comp. Rend. Acad. Paris, 270, 912 - 915, (1970).

75. Malpas, J. and Langdon, G., Petrology of the upper pillow lava suite, Troodos ophiolites, Cyprus. In Gass, I.G., Lippard, S.J. and Shelton, A.W., (eds). Ophiolites and Oceanic Lithosphere. Geol. Soc. Spec. Publ., no.13, Blackwell Scientific Publication, 155 - 167 (1984).

76. Manzer, Jr., G.K., Heinlich, R.A., Petrology and geochemistry of mafic and ultramafic rocks from the Northern Bighorn Mountains, Wyoming. Geol. Soc. Amer. Bull., vol.85, 703 - 708 (1974).

77. Middlemost, Eric, A.K., Magmas and magmatic rocks : an introduction to igneous petrology. Longman Group. Inc, N.Y., 93 - 116, (1985).

78. Miyashiro, A., Classification characteristics, and origin of ophiolite. Jour. Geol., vol.83, no.2, 249 - 281 (1975).

79. ------, and Shido, F., Tholeiitic and calc-alkalic series in relation to the behavior of titanium, vanadium, chromium, and nickel. Amer. Jour. of Sci., vol.275, 265 - 277 (1975).

80. ------, Subduction-zone ophiolites and island-arc ophiolites. Energetics of geological processes, 188 - 212 (1977).

81. Molnar, P., Tapponier, P., Cenozoic Tectonics of Asia : Effects of a continental collision. Science, vol. 189, no.4201, 419-426 (1975). . 
82. Montigny, R., Bougault, H., Bottinga, Y., Allegre, C.J., Trace element geochemistry and genesis of the Pindos ophiolite suite. Geochim. Cosmochim. Acta, vol.37, 2135 - 2147 (1973).

83. Moore, G.F. \& Karig, D.E., Development of sedimentary basins on the lower trench slope. Geology, vol. 4, 693-697 (1976).

84. Moore, G.F., Structural geology and sedimentology of Nias Island, Indonesia : A Study of Subduction zone tectonics and sedimentation. Unpublished, Ph.D. Dissertation, Cornell University, 142 p. (1978).

85. Mullen, E.D., $\mathrm{MnO} / \mathrm{TiO}_{2} / \mathrm{P}_{2} \mathrm{O}_{5}$ : A minor element discriminant for basaltic rocks of oceanic environments and its implications for petrogenesis. Earth. Planet. Sci. Lett., vol.62, 53 - 62 (1983).

86. Nicolas, A., Stucture and petrology of peridotite : Clues to their geodynamic environment. Rev. Geophys., vol.24, no.4, 875 - 895 (1986).

87. Nishimura, S., Suparka, S., Paleogeographic reconstruction and origin of the Banda Sea, Indonesia (in prep.).

88. Noiret, G., Montigny, R., Allegre, C.J., Is the Vourinos complex an island arc ophiolite ?. Earth. Planet. Sci. Lett., vol.56, 375 - 386 (1982).

89. Nystrom, J.O., Rare earth element mobility in vesicular lava during low-grade metamorphism. Contrib. Mineral. Petrol, vol.88, 328 - 331 (1984).

90. Ogawa, Y., Naka, J., Emplacement of ophiolitic rocks in fore arc areas : Examples from central Japan and Izu - Mariana - Yap Island arc system. In gass, I.G., Lippard, S.J., and Shelton, A.W. (eds). Ophiolite and Lithosphere. Geol. Soc. Spec. Publ., no.13, 291-301 (1984).

91. Ohnenstetter, D., Ohnenstetter, M., L'ensemble effusif et hypabyssal des ophiolites Corses. Sciences de la terre, Tome XXII, 201 - 242 (1978). 
92. Onuki, H., and Kato, Y., Some gabbroic rocks of the Tabito plutonic complex in the Abukuma Plateau. The Science Reports of the Tohoku University, vol.XI, no.2, 113 - 123 (1971). Oxburgh, E.R., Turcotte, D.L., Origin of paired metamorphic belts and crustal dilation in island arc regions. Jour. Geophys. Res., vol.76, no.5, (1971).

93. Oxburgh, E.R. Turcotte, D.L., Origin of paired metamorphic belts and crustal dillation in island arc regions. Jour. Geophys. Res., vol. 76, no. 5 (1971).

94. Pallister, J.S., and Hopson, C.A., Samail ophiolite plutonic suite : Field relations, phase variation, cryptic and layering, and a model of a spreading ridge magma chamber. Jour. Geophys. Res., vol.86, no.B 4, 2593 - 2644 (1981).

95. -------, Knight, R.J., Rare-earth element geochemistry of the Samail ophiolite near Ibra, Oman. Jour. Geophys. Res., vol.86, no.b 4, 2673-2697 (1981).

96. -----, Parent magmas of the Samail ophiolite, Oman. In Gass, I.G., Lippard, S.J., and Shelton, A.W. (eds). Ophiolites and Oceanic Lithosphere. Geol. Soc. Special Publ., no.13, Blackwell Scientific Publications, 63 - 70 (1984).

97. Pearce, J.A., and Cann, J.R., Tectonic setting of basic volcanic rocks determined using trace element analyses. Earth. Planet. Sci. Lett., vol.19, 290 -300 (1973).

98. ------, and Norry, J., Petrogenetic implications of $\mathrm{Ti}, \mathrm{Zr}, \mathrm{Y}$, and $\mathrm{Nb}$ variations in volcanic rocks. Contrib. Mineral. Petrol., vol.69, 33 - 47 (1979).

99. Pearce, T.H., Gorman, B.E., and Birkett, T.C., The $\mathrm{TiO}_{2}-\mathrm{K}_{2} \mathrm{O}-\mathrm{P}_{2} \mathrm{O}_{5}$ Diagram : A Method of discriminating between oceanic and non-oceanic basalts. Earth. Planet. Sci. Lett., vol.24, 419 - 426 (1975).

100. -----, Gorman, B.E., Birkett, T.C., The relationship between major element chemistry and tectonic environment of basic and intermediate volcanic rocks. Earth. Planet. Sci. Lett., vol.36, 121 - 132 (1977). 
101. Pelletier, B., Stephan, J.f., Middle Miocene obduction and Late Miocene begining of collision registered in the Heng Chun Peninsula : Geodynamic implications for the evolution of Taiwan. Tectonophysics, vol.125, 133 - 160 (1986).

102. Penrose field conference of ophiolites. Geotime, vol.17, no.12, 24-25 (1972).

103. Perfit, M.R., Gust, D.A., Bence, A.E., Arculus, R.J., Chemical characristics of island - arc basalts : Implications for Mantle Sources. Chem. Geol, vol. 30, 227 -256 (1980).

104. Pike, J.E.N., Meyer, C.E., and Wilshire, H.G., Petrography and chemical composition of a suite of ultramafic xenolith from Lashaine, Tanzania. Jour. Geol. vol.88, no.3, 343 - 352 (1980).

105. Presnall, D.C., Dixon, J.R., O'donnell, T.H., and Dixon, S.A., Generation of mid-ocean ridge tholeiites. Jour. Petrol., vol.20, Part I, 3 - 35 (1979).

106. Prinzofer, A., and Nicolas, A., Cumulative or residual origin for the transition zone in ophiolites : structural evidence. Jour. Petrol., vol.24, Part 2, 188-206 (1983).

107. ------, and Allegre, C.J., Residual peridotites and the mechanisms of partial melting. Earth. Planet. Sci. Lett., vol.74, 251 - 265 (1985).

108. Qasim Jan, M., Windley, B.F., \& Khan, A., The Waziristan ophiolite, Pakistan : General geology and chemistry of chromite and associated phases. Econ. Geol., vol.80, 294 - 306 (1985).

109. Rachman, A., Kedudukan serpentinit-basalt-gabro di daerah Karakelang Selatan, Kepulauan Talaud, Sulawesi Utara. Lap. tak terbit, tesis S-1, ITB., 51 hal. (1977).

110. Ridd, M.F., Possible Paleozoic drift of SE Asia and Triassic collision with 
China. Jour. Geol. Soc. London, vol.137, 635-640 (1980).

111. Ringwood, A.E., Petrogenesis in island arc systems. In Talwani, M., and Pitman III, W.C. (eds). Island Arcs Deep Sea Trenches and Back Arc Basins. Maurice Ewing Series 1, 311 - 324 (1977).

112. Rodgers, K.A., A Comparison of the geology of the Papuan and New Caledonian Ultramafic belts. Jour. Geol., vol.83, 47 - 60 (1975).

113. Sanders, A.D. The earth element characteristics of igneous rocks from the ocean basins, In P. Henderson (ed). Development in Geochemistry, vol.2, 205 $-231(1984)$.

114. Sartono, S., Olistostrom sebagai batuan dasar di Jawa. PIT-IAGI XVI (1987)

115. Scarle, M.P., and Malpas, J., Petrochemistry and origin of sub-ophiolitic metamorphic and related rocks in the Oman Mountains. Jour. Geol. Soc. London, vol.139, 235 - 248 (1982).

116. Schilling J.G., Sea - floor evolution : rare earth evidence. Phil. Trans. Roy. Soc. London Ser., A 268, 663 - 706 (1971).

117 Schmincke, H.U., Rautenshlein, M., Robinson, P.T., Mehegan, J.M., Troodos extrusive series of Cyprus : A Comparison with oceanic crust. Geology, vol.11, 405 - 409 (1983).

118 Sclater, J.G., and Fisher, R.L., Evolution of the East - Central Indian Ocean, with emphasis on the tectonic setting of the Ninetyeast Ridge. Geol. Soc. Amer. Bull., vol.85, no. 5, 633-702 (1974).

119. Searle, M.P., Steven, R.K., Obduction Processes in ancient, modern and future ophiolites. In Gass, I.G., Lippard, S.J., and Shelton, A.W. (eds). Ophiolite and Lithosphere. Geol. Soc. Spec. Publ., no.13, 303 - 319 (1984).

120. Shervais, J.W., Ti-V plots and the petrogenesis of modern and ophiolitic lavas. 
Earth. Planet. Sci. Lett., vol.59, 101 - 118 (1982).

121. Shido, F., Miyashiro, A., and Ewing, M., Crystallization of abyssal tholeiites. Contrib. Mineral and Petrol., vol.36, 251 - 266 (1971).

122. Sikumbang, N., Geology and tectonics of pre-Tertiary rocks in the Meratus Mountains. S.E. Kalimantan, Indonesia. Unpublished, Ph.D. dissertation, Univ. of London, 389 p. (1986).

123. Sinton, J.M., Petrology and evolution of Red Mountain ophiolite complex, New Zealand. Amer. Jour. Sci., vol.280 A, Part I, 296 - 328 (1980).

124. Situmorang, B., Emplacement of the Meratus ultrabasic massif : a gravity interpretation. Lemigas, Sci. Contrib., no.2, 61 - 72 (1988).

125. Soejono, M., Suparka, S., Hadiwisastra, S., Status Formasi Ciletuh dalam evolusi Jawa Barat. Geologi indonesia, vol.5, no.2, 29 - 38 (1978).

126. Soeria Atmadja, R., Golightly, J.P., Wahyu, B.N., Mafic and ultramafic rock associations in the east arc of Sulawesi. Proceedings ITB, vol.8, no.2, 67 - 85 (1974).

127. ------, Sukamto, R., Ophiolite rock association on Talaud Island, East Indonesia. Bull. Geol. Res. and Center, vol.1, 17 - 35 (1979).

128. ------, Ophiolites in the Halmahera paired belts, East Indonesia : The Geology and tectonics of Eastern Indonesia. Geol. Res. and Develop. Centre, Spec. Publ., no.2, 363 - 372 (1981).

129. Sopaheluwakan, J., Simandjuntak, H.R.W., Notes on the structural features of the ophiolitic and associated rocks in the Meratus-Bobaris Ranges, SE Kalimantan. A Preliminary result. Direktorat Sumber Daya Mineral, Departemen Pertambangan dan Energi R.I., 1 - 29 (1983).

130. Stephan, J.F., Blanchet, R., Rangin, C., Pelletier, B., Letouzey, J., Muller, C., 
Geodynamic evolution of the Taiwan - Luzon - Mindoro Belt since the Late Eocene. Tectonophysics, vol.125, 245 - 268 (1986).

131. Subbarao, R.V. and Reddy, V.V., Geochemical studies on oceanic basalts from the Indian ocean. Tectonophysics, vol.75, 69 - 89 (1981).

132. Suen, C.J., Frey, F.A., Bay of Islands ophiolite suite Newfoundland : petrographic and geochemical characteristics with emphasis on rare earth element geochemistry. Earth. Planet. Sci. Lett., vol.45, 337 - 348 (1979).

133. Sukendar, A., Evolusi geologi Jawa Tengah dan sekitarnya ditinjau dari segi tektonik dunia yang baru. Lap. tak terbit, disertasi, Dept. Teknik Geol.ITB., 103 hal.(1974).

134. Suparka, S., Perkembangan tektonik daerah Jampang, Jawa Barat berdasarkan pengamatan struktur geologi. Teknologi Indonesia, III, no.1, 17 33 (1980).

135. Tapponier, P., Peltzer, G., Le Dain, A.Y., Armijo, R., Propagating extrusion tectonics in Asia : New insight from simple experiments with plasticine. Geology, vol.10, 611-616 (1982).

136. Tjia, H.D., Structural Analyses of the Pre-Tertiary of the Lokulo area, Central Java. Ph.D. dissertation. Contribution from the Departement of Geology ITB, no. 63 (1966).

137. Tlig, S., Steinberg, M., Distribution of rare-earth elements (REE) in size fractions of recent sediments of the Indian Ocean. Chem. Geol., vol.37, no.3/4, $317-333$ (1982).

138. Uyeda, S., Some basic problems in the Trench - Arc - Back - Arc system. In Talwani, M., and Pitman III, W.C. (eds). Island Arcs Deep Sea Trenches and Back Arc Basins. Maurice Ewing Series 1, 1 - 14 (1977). 
139. -----, Kanamori, H., Back-arc opening and the mode of subduction. Jour. Geophys. Res., vol.84, 1049 - 1061 (1979).

140. -----, Comparative subductology. Episodes, vol.2, 19 - 25 (1983).

141. Venturelli, G., Capedri, S., Thorpe, R.S., Patts, P.J., Rare earth and other element distribution in some ophiolitic metabasalt of Corsica, Western Mediterranean. Chem. Geol., vol.24, 339 - 353 (1979).

142. -----, Thorpe, R.S., and Potts, P.J., Rare earth and trace element characteristics of ophiolitic metabasalts from the Alpine - Apennine belt. Earth. Planet. Sci. Lett., vol.53, 109 - 123 (1981).

143. Welland, M.J.P., Mitchell, A.H.G., Emplacement of the Oman ophiolite : a mechanism related to subduction and collision. Geol. Soc. Amer. Bull., vol.88, 1081 - 1088 (1977).

144. White, W.M., Sources of oceanic basalts : Radiogenic isotopic evidence. Geology, vol.13, 115 - 118 (1985).

145. Wiryosudjono, S., and Tjokrosapoetro, S., Ophiolites in eastern Indonesia. 3th. Regional conference of geology and mineral resources of Southeast Asia, Bangkok, Thailand (1988).

146. Yuwono, Y.S., Petrologie des ensembles magmatiques du Sud de la chaine des Meratus (Kalimantan, Indonesie) et donnees preliminaire sur le magmatisme du Sud-Ouest de Sulawesi (Indonesie). Rapport du Stage, DEA, Universite' de Bretagne Occidentale, France (1984).

147. ------, Contribution a l'Etude du volcanisme potassique de l'Indonesie. Exemples du Sud-Ouest de Sulawesi et du Volcan Muria. These de Doctorat de L’Universite de Bretagne Occidentale, univ. Brest (1986).

148. ------, Priyosumarso, S., Maury, R.C., Rampnoux, J.P., Soeria Atmadja, R., 
Bellon, H., and Chotin, P., Petrology of the Cretaceous magmatic rokcs from Meratus Range, Southeast Kalimantan, Jour. of Southeast Asian Earth Sci., vol. 2, No.1, pp. 15-22, (1988). 
LAM P I RA N 
CENTRAL JAVA : KARANGSAMBUng COMPLEX

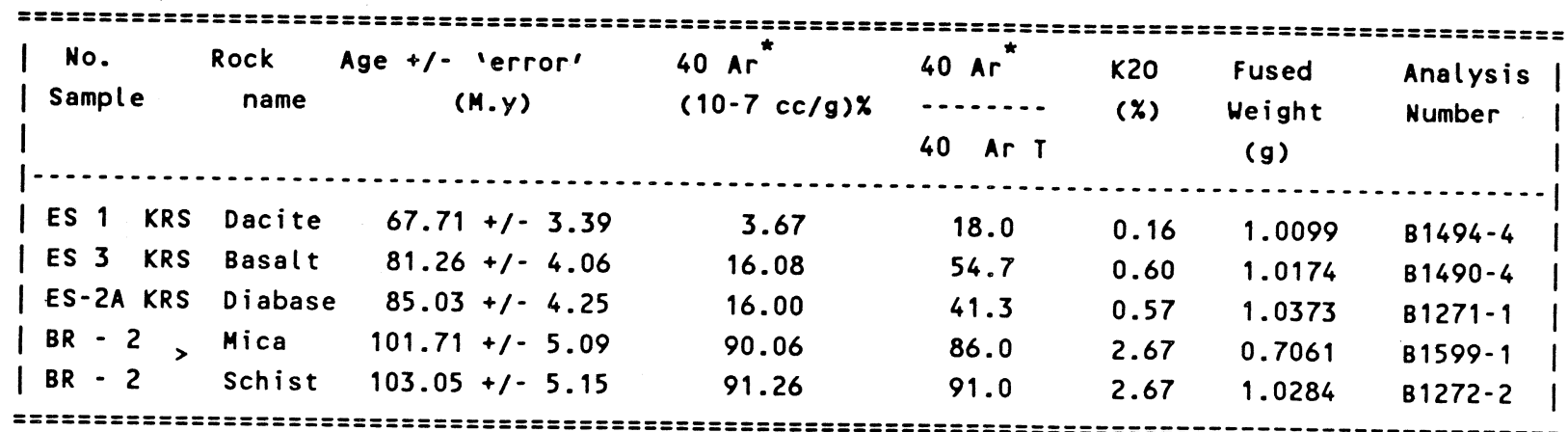

recommended by R.H. Steiger and E. Jager (1977) according to the following formula :

$t=4154.04 \log \langle 10\rangle\left\{1+142.69\left(40 \mathrm{Ar}^{\star}: \mathrm{K}\right)\right\}$

$40 \mathrm{Ar}^{\star}$ in c.c. - $K$ in $\mathrm{g}$. - $t$ in million years

$40 \mathrm{~K}=.01167 \%$ of $K$ total in atoms

Error = Physical uncertainty of measurement

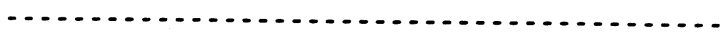

Laboratoire de Geochimie

Universite de Bretagne Occidentale - GIS Oceanologie et Geodynamique 29287 BREST Cedex, FRANCE

Tabel 11.1. Umur absolut berdasarkan metoda $K$-Ar beberapa batuan yang dipilih dari Karangsambung Utara. 


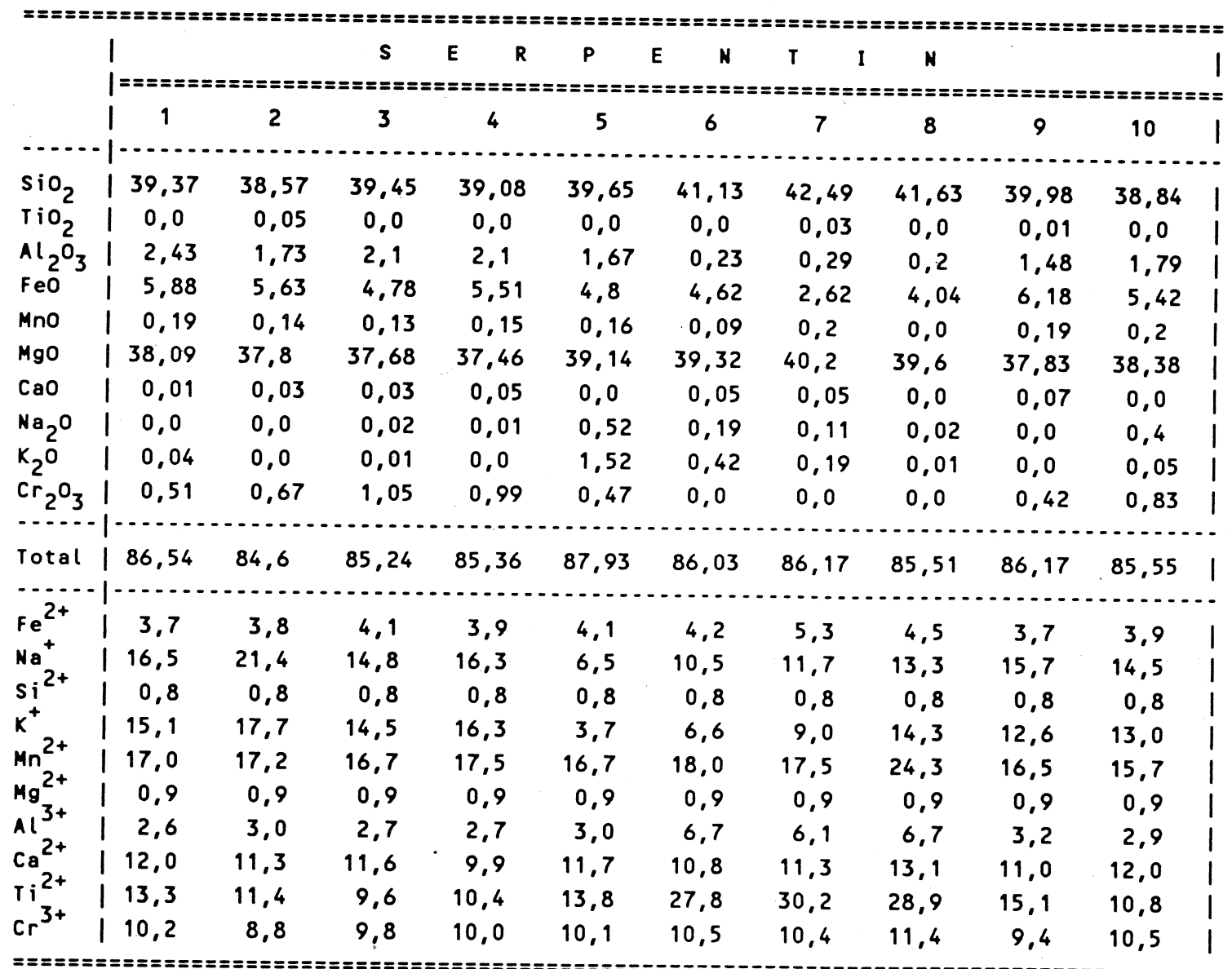

Tabel III.1a. Hasil analisis mikroprob serpentin dari batuan serpentinit (CD - 49) daerah Karangsambung Utara. 


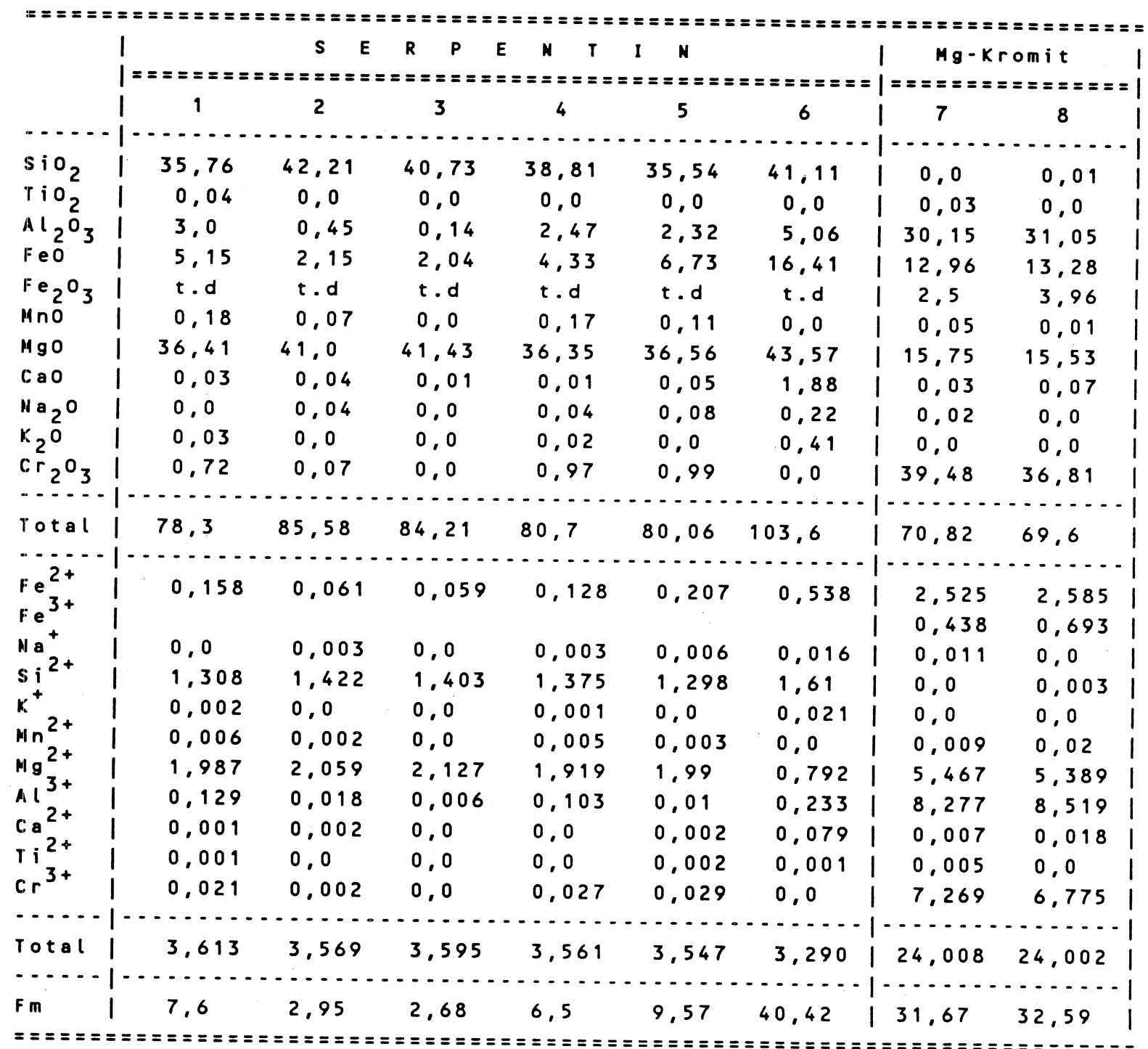

Tabel III.1b. Hasil analisis mikroprob serpentin dan Mg - kromit dari batuan serpentinit ( $S L$ - $3 B$ ) Karangsambung Utara.

t.d: Tidak dianalisis. 


\begin{tabular}{|c|c|c|c|c|c|c|c|c|c|c|c|c|c|}
\hline & & $\mathbf{P}$ & L A & G I & $0 \quad K$ & L A & $S$ & & I L & MEN I & & & HORNBLENDA \\
\hline & $:=====$ & $=======$ & $=========$ & $y== \pm=$ & $==== \pm$ & :==:==s & & & & & & & \\
\hline & 1 & 2 & 3 & 4 & 5 & 6 & 7 & 8 & 9 & 10 & 11 & 12 & 13 \\
\hline $\mathrm{SiO}_{2}$ & 51,74 & 51,69 & 51,72 & 52,28 & 51,59 & 54,62 & 54,44 & 53,81 & 2,31 & 0,59 & 0,0 & 10,0 & 52,67 \\
\hline $\mathrm{TiO}_{2}$ & 0,05 & 0,06 & 0,04 & 0,03 & 0,0 & 0,11 & 0,01 & 0,07 & 5,93 & 51,43 & 54,11 & 10,04 & 0,51 \\
\hline & 29,88 & 30,32 & 30,84 & 30,06 & 30,45 & 27,63 & 27,59 & 28,15 & $1 \quad 0,71$ & 0,12 & 0,0 & 10,08 & 04,27 \\
\hline $\mathrm{FeO}^{2}$ & 0,4 & 0,43 & 0,52 & 0,4 & 0,47 & 0,9 & 0,3 & 0,33 & 134,64 & 39,59 & 39,17 & I 2,74 & 10,48 \\
\hline Mno & 0,0 & 0,0 & 0,0 & 0,0 & 0,02 & 0,07 & 0,0 & 0,1 & | 0,15 . & 3,67 & 7,01 & 10,03 & 0,03 \\
\hline MgO & 0,12 & 0,07 & 0,12 & 0,11 & 0,09 & 0,05 & 0,05 & 0,01 & $1 \quad 0,27$ & 0,2 & 0,14 & 10,0 & 17,31 \\
\hline $\mathrm{CaO}$ & 13,45 & 13,58 & 13,51 & 13,05 & 13,21 & 10,58 & 10,4 & 10,24 & $1 \quad 1,0$ & 1,23 & 0,46 & 10,06 & 11,86 \\
\hline $\mathrm{Na}_{2} \mathrm{O}$ & 3,88 & 4,03 & 3,74 & 4,2 & 3,99 & 5,55 & 5,66 & 5,21 & 10,08 & 0,02 & 0,0 & 10,0 & 0,61 \\
\hline $\mathrm{K}_{2} \mathrm{O}$ & 0,03 & 0,04 & 0,0 & 0,06 & 0,05 & 0,09 & 0,0 & 0,07 & 0,01 & 0,0 & 0,0 & I $\quad 0,21$ & 0,05 \\
\hline $\mathrm{Cr}_{2} \mathrm{O}_{3}$ & 0,0 & 0,04 & 0,07 & 0,0 & 0,03 & 0,0 & 0,0 & 0,11 & 0,39 & 0,13 & 0,46 & 10,75 & 0,14 \\
\hline Total & 199,55 & 100,25 & 100,58 & 100,19 & 99,89 & 98,88 & 98,46 & 98,05 & 198,67 & 96,99 & 100,89 & 196,64 & 100,04 \\
\hline & 0,015 & 0,016 & 0,02 & 0,015 & 0,018 & 0,007 & 0,011 & 0,013 & 18,75 & 1,701 & 1,627 & 0,096 & 1,246 \\
\hline $\mathrm{Fe}^{3+}$ & 0,0 & 0,0 & 0,0 & 0,0 & 0,0 & 0,0 & 0,0 & 0,0 & 12,086 & 0,0 & 0,0 & 0,0 & 0,0 \\
\hline $\mathrm{Na}^{+}$ & 0,343 & 0,355 & 0,328 & 0,37 & 0,352 & 0,491 & 0,503 & 0,465 & | 0,046 & 0,001 & 0,0 & 0,0 & 0,168 \\
\hline $\mathrm{Si}^{2+}$ & 2,364 & 2,349 & 2,34 & 2,372 & 2,35 & 2,492 & 2,494 & 2,474 & 0,098 & 0,031 & 0,0 & 0,009 & 7,489 \\
\hline $\mathrm{K}^{+}$ & 0,002 & 0,002 & 0,0 & 0,004 & 0,003 & 0,005 & 0,0 & 0,003 & 0,004 & 0,0 & 0,0 & 0,002 & 0,01 \\
\hline $\mathrm{Mn}^{2+}$ & 0,0 & 0,0 & 0,0 & 0,0 & 0,001 & 0,003 & 0,0 & 0,003 & 0,039 & 0,16 & 0,295 & 0,0 & 0,004 \\
\hline $\mathrm{Mg}^{2+}$ & 0,008 & 0,005 & 0,009 & 0,008 & 0,006 & 0,004 & 0,003 & 0,0 & 0,122 & 0,016 & 0,01 & 0,005 & 3,669 \\
\hline $\mathrm{Al}^{3+}$ & 1,609 & 1,524 & 1,644 & 1,607 & 1,635 & 1,486 & 1,489 & 1,523 & 0,252 & 0,007 & 0,0 & 0,003 & 0,715 \\
\hline $\mathrm{Ca}^{2+}$ & 0,659 & 0,661 & 0,655 & 0,634 & 0,645 & 0,516 & 0,51 & 0,504 & 0,324 & 0,068 & 0,024 & 0,033 & 1,806 \\
\hline $\mathrm{Ti}^{2+}$ & 0,002 & 0,002 & 0,002 & 0,001 & 0,0 & 0,003 & 0,0 & 0,003 & 1,348 & 1,987 & 2,021 & 2,92 & 0,055 \\
\hline $\mathrm{Cr}^{3+}$ & 0,0 & 0,001 & 0,003 & 0,0 & 0,001 & 0,0 & 0,0 & 0,003 & 0,093 & 0,068 & 0,024 & 0,001 & 0,016 \\
\hline Total & 5,002 & 5,015 & 4,999 & 5,01 & 5,009 & 5,009 & 5,012 & 4,994 & 123,762 & 3,977 & 3,978 & 3,07 & 16,178 \\
\hline Fm & 64,88 & & & & 75,7 & & & & 0.986 & & & & 25,41 \\
\hline$A b$ & 34,21 & 34,86 & $\begin{array}{l}70,71 \\
33,4\end{array}$ & $\begin{array}{l}66,1 \\
36,69\end{array}$ & 35,23 & 48,49 & 49,62 & 47,76 & 0,980 & 99,17 & 99,47 & 0,948 & $0,0,1$ \\
\hline Or & 0,16 & 0,24 & 0,0 & 0,35 & 0,28 & 0,53 & 0,02 & 0,39 & 1 & & & 1 & \\
\hline An & 165,63 & 64,9 & 66,6 & 62,97 & 64,49 & 50,98 & 50,36 & 51,85 & 1 & & & i & \\
\hline
\end{tabular}

Tabel 111.2. Hasil analisis mikroprob plagioklas, ilmenit, sfen, serta hornblenda batuan gabro (PS - 6, CD - 7) Karangsambung Utara. 


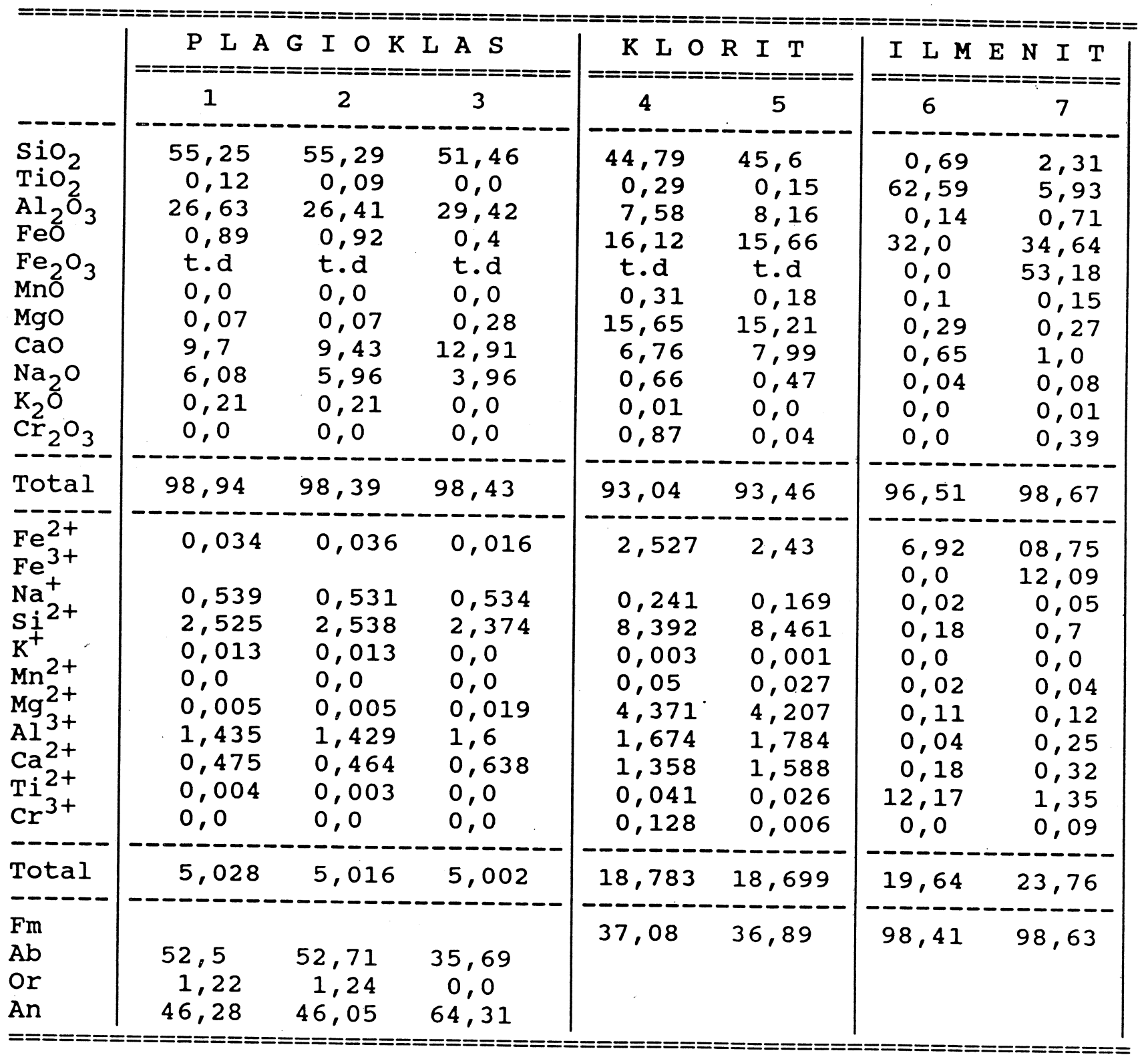

Tabel III.3. Hasil analisis mikroprob plagioklas, klorit, dan ilmenit batuan basalt (ST-69) Karangsambung Utara.

t.d : Tidak dianalisis. 


\begin{tabular}{|c|c|c|c|c|}
\hline & \multicolumn{4}{|c|}{$\begin{array}{l}P \text { I R O K S E N } \\
========+\end{array}$} \\
\hline & 1 & 2 & 3 & 4 \\
\hline $\begin{array}{l}\mathrm{SiO}_{2} \\
\mathrm{TiO}_{2} \\
\mathrm{Al}_{2} \mathrm{O}_{3} \\
\mathrm{FeO} \\
\mathrm{MnO} \\
\mathrm{MgO} \\
\mathrm{CaO} \\
\mathrm{Na}_{2} \mathrm{O} \\
\mathrm{K}_{2} \mathrm{O} \\
\mathrm{Cr}_{2} \mathrm{O}_{3}\end{array}$ & $\begin{array}{c}51,09 \\
0,0 \\
2,18 \\
9,92 \\
0,22 \\
15,04 \\
19,52 \\
0,49 \\
0,0 \\
0,0\end{array}$ & $\begin{array}{c}51,06 \\
1,02 \\
2,3 \\
10,56 \\
0,18 \\
15,0 \\
18,53 \\
0,42 \\
0,0 \\
0,03\end{array}$ & $\begin{array}{r}50,68 \\
0,76 \\
2,34 \\
9,64 \\
0,27 \\
14,86 \\
19,31 \\
0,52 \\
0,0 \\
0,15\end{array}$ & $\begin{aligned} & 50, 82 \\
& 0, 77 \\
& 2,1 \\
& 10,11 \\
& 0,17 \\
& 15,37 \\
& 19,36 \\
& 0,34 \\
& 0,0 \\
& 0,07\end{aligned}$ \\
\hline Total & 98,46 & 99,1 & 98,54 & 99,1 \\
\hline $\begin{array}{l}\mathrm{Si}^{2+} \\
\mathrm{Ti}^{2+} \\
\mathrm{Al}^{3+} \\
\mathrm{Fe}^{2+} \\
\mathrm{Mn}^{2+} \\
\mathrm{Mg}_{2+}^{2+} \\
\mathrm{Ca}^{2+} \\
\mathrm{Na}^{+} \\
\mathrm{K}^{+} \\
\mathrm{Cr}^{3+}\end{array}$ & $\begin{array}{l}1,92 \\
0,0 \\
0,097 \\
0,312 \\
0,007 \\
0,842 \\
0,786 \\
0,036 \\
0,0 \\
0,0\end{array}$ & $\begin{array}{l}1,916 \\
0,029 \\
0,102 \\
0,331 \\
0,006 \\
0,839 \\
0,745 \\
0,031 \\
0,0 \\
0,001\end{array}$ & $\begin{array}{l}1,908 \\
0,022 \\
0,104 \\
0,303 \\
0,009 \\
0,834 \\
0,779 \\
0,038 \\
0,0 \\
0,004\end{array}$ & $\begin{array}{l}1,903 \\
0,022 \\
0,093 \\
0,317 \\
0,005 \\
0,858 \\
0,777 \\
0,025 \\
0,0 \\
0,002\end{array}$ \\
\hline Total & 4,0 & 4,0 & 4,0 & 4,0 \\
\hline $\begin{array}{l}\text { WO } \\
\mathrm{EN} \\
\mathrm{FS} \\
\mathrm{Al} \mathrm{IV} \\
\mathrm{Al} \mathrm{VI} \\
\mathrm{Fe}^{3+} \\
\mathrm{Fe}^{2+} \\
\mathrm{AlIV} / \mathrm{Al} \\
\mathrm{Al} / \mathrm{Ti}^{+} \\
\mathrm{Mg} / \mathrm{Mg}^{+} \mathrm{Fe} \\
\mathrm{Fe} / \mathrm{Fe}^{+} \mathrm{Mg}\end{array}$ & $\begin{array}{c}40,368 \\
43,26 \\
16,019 \\
0,08 \\
0,017 \\
0,099 \\
0,213 \\
4,731 \\
\text { ERR } \\
0,73 \\
0,27\end{array}$ & $\begin{array}{r}38,784 \\
43,667 \\
17,257 \\
0,084 \\
0,018 \\
0,037 \\
0,294 \\
4,577 \\
3,535 \\
0,717 \\
0,283\end{array}$ & $\begin{array}{c}40,469 \\
43,315 \\
15,777 \\
0,092 \\
0,012 \\
0,071 \\
0,232 \\
8,01 \\
4,827 \\
0,733 \\
0,267\end{array}$ & $\begin{array}{c}39,702 \\
43,84 \\
16,188 \\
0,097 \\
0,0 \\
0,081 \\
0,235 \\
\text { ERR } \\
4,275 \\
0,73 \\
0,27\end{array}$ \\
\hline
\end{tabular}

Tabel III.4. Hasil analisis mikroprob piroksen dari gabro (CD-\&) Karangsambung Utara. 


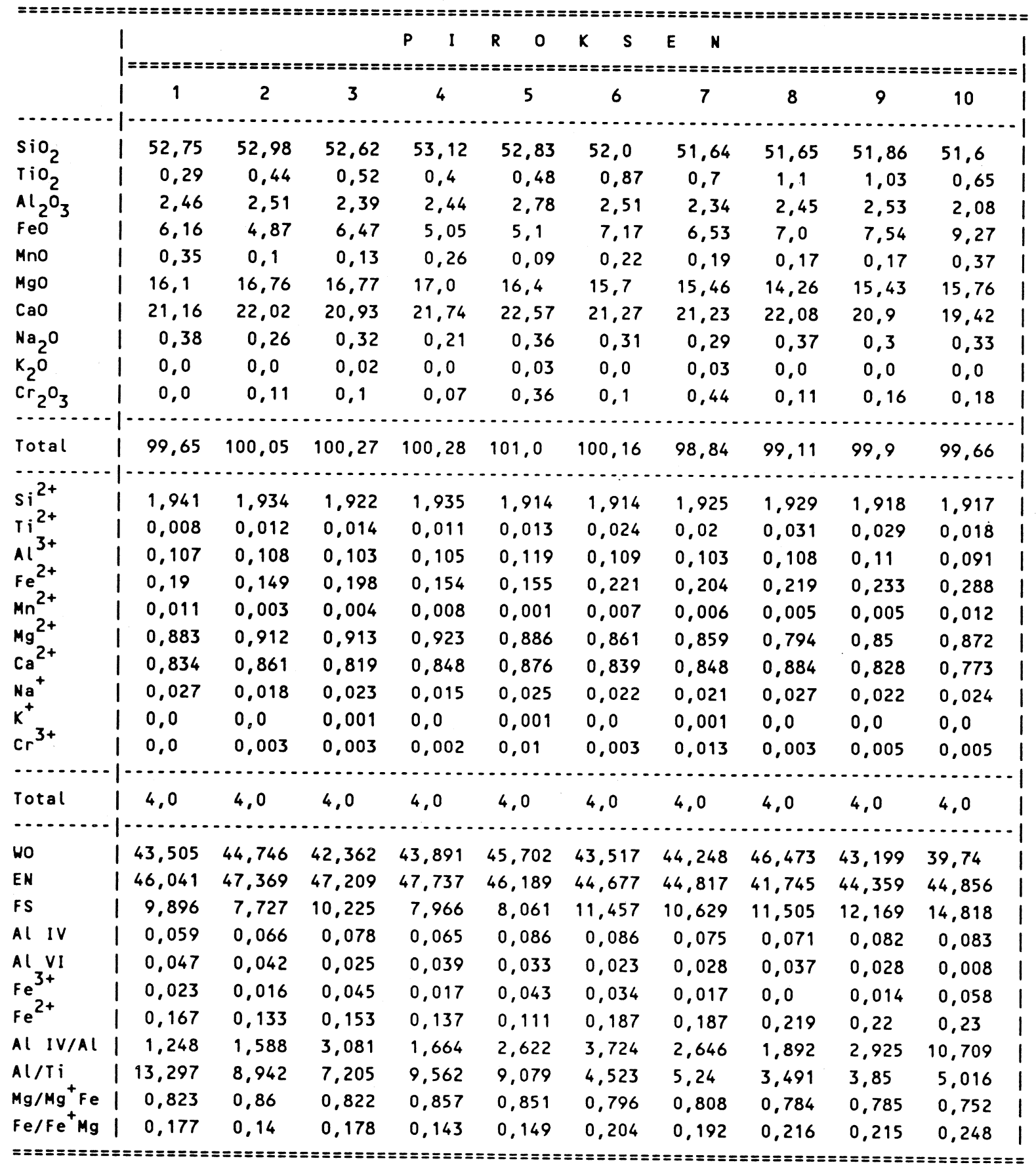

Tabel III.5. Hasil analisis mikroprob piroksen batuan gabro (PS - 16) Karangsambung Utara. 


\begin{tabular}{|c|c|c|c|c|c|c|c|c|c|c|}
\hline & 1 & & & B & A S & $\begin{array}{lll}A & L & T\end{array}$ & & & & 1 \\
\hline & 1 & 5 & 6 & 7 & 8 & 9 & 10 & 11 & 12 & \\
\hline $\mathrm{SiO}_{2}$ & 1 & 46,39 & 52,42 & 49,85 & 49,52 & 50,94 & 50,43 & 50,59 & 50,77 & 1 \\
\hline $\mathrm{TiO}_{2}$ & 1 & 1,89 & 0,1 & 0,44 & 0,61 & 0,68 & 0,46 & 0,58 & 1,0 & 1 \\
\hline $\mathrm{Al}_{2} \mathrm{O}_{3}$ & 1 & 6,99 & 0,79 & 3,96 & 4,94 & 3,37 & 4,06 & 4,39 & 2,37 & 1 \\
\hline $\mathrm{FeO}$ & 1 & 9.22 & 7,97 & 4,82 & 2,21 & 6.71 & 5,47 & 5,3 & 9.75 & 1 \\
\hline Mno & 1 & 0,23 & 0,16 & 0,09 & 0,0 & 0,12 & 0,0 & 0,0 & 0,21 & 1 \\
\hline MgO & 1 & 15,73 & 15,03 & 17,62 & 16,25 & 17,34 & 16,17 & 16,89 & 14,79 & 1 \\
\hline $\mathrm{CaO}$ & 1 & 14,35 & 21,64 & 19,67 & 20,56 & 18,95 & 20,12 & 19,17 & 19,73 & 1 \\
\hline $\mathrm{Na}_{2} \mathrm{O}$ & 1 & 2,02 & 0,22 & 0,36 & 0,28 & 0,39 & 0,26 & 0,24 & 0,43 & 1 \\
\hline $\mathrm{K}_{2} \mathrm{O}$ & 1 & 0,54 & 0,04 & 0,0 & 0,0 & 0,0 & 0,0 & 0,0 & 0,0 & 1 \\
\hline $\mathrm{Cr}_{2} \mathrm{O}_{3}$ & 1 & 0,0 & 0.03 & 1,76 & 1,52 & 0,09 & 1,3 & 0,69 & 0,08 & i \\
\hline Total & 1 & 97,36 & 98,40 & 98,57 & 95,89 & 98,59 & 98,27 & 97,85 & 99,13 & 1 \\
\hline & & & & & & & . & & . & \\
\hline $\mathrm{Si}^{2+}$ & 1 & 1,728 & 1,972 & 1,84 & 1,875 & 1,885 & 1,88 & 1,885 & 1,903 & 1 \\
\hline $\mathrm{Ti}_{3+}^{2+}$ & i & 0,053 & 0,003 & 0,012 & 0,017 & 0,019 & 0,013 & 0,016 & 0,028 & 1 \\
\hline $\mathrm{Al}^{\mathrm{St}}$ & 1 & 0,307 & 0,035 & 0,172 & 0,221 & 0,147 & 0,178 & 0,193 & 0,105 & 1 \\
\hline $\mathrm{Fe}^{2+}$ & i & 0,287 & 0,251 & 0,149 & 0,07 & 0,208 & 0,17 & 0,165 & 0,306 & 1 \\
\hline $\mathrm{Mn}_{2+}^{2+}$ & 1 & 0,007 & 0,005 & 0,003 & 0,0 & 0,004 & 0,0 & 0,0 & 0,007 & 1 \\
\hline $\mathrm{Mg}^{2+}$ & i & 0,873 & 0,843 & 0,969 & 0,917 & 0,956 & 0,898 & 0,938 & 0,826 & 1 \\
\hline $\mathrm{Ca}^{2+}$ & 1 & 0,573 & 0,872 & 0,778 & 0,834 & 0,751 & 0,803 & 0,765 & 0,792 & 1 \\
\hline $\mathrm{Na}^{+}$ & i & 0,146 & 0,016 & 0,026 & 0,021 & 0,028 & 0,019 & 0,017 & 0,031 & 1 \\
\hline $\mathrm{K}^{+}$ & 1 & 0,026 & 0,002 & 0,0 & 0,0 & 0,0 & 0,0 & 0,0 & 0,0 & 1 \\
\hline $\mathrm{Cr}^{3+}$ & i & 0,0 & 0,001 & 0,051 & 0,045 & 0,003 & 0,038 & 0,02 & 0,002 & 1 \\
\hline Total & 1 & 4,0 & 4,0 & 4,0 & 4,0 & 4,0 & 4.0 & 4,0 & 4,0 & 1 \\
\hline Wo & $i$ & 32,908 & 44,261 & 40,97 & 45,804 & 39,153 & 42,918 & 40,963 & 41,038 & 1 \\
\hline En & 1 & 50,172 & 42,757 & 51,046 & 50,353 & 49,83 & 47,975 & 50,198 & 42,788 & 1 \\
\hline Fs & 1 & 16,51 & 12,728 & 7,839 & 3,843 & 10,825 & 9,107 & 8,839 & 15,835 & 1 \\
\hline Al IV & 1 & 0,272 & 0,028 & 0,16 & 0,125 & 0,115 & 0,12 & 0,115 & 0,097 & 1 \\
\hline $\mathrm{Al}_{3+} \mathrm{VI}$ & 1 & 0,035 & 0,007 & 0,012 & 0,095 & 0,032 & 0,058 & 0,078 & 0,007 & I \\
\hline $\mathrm{Fe}^{3+}$ & 1 & 0,03 & 0,032 & 0,098 & 0,0 & 0,071 & 0,017 & 0,002 & 0,062 & I \\
\hline $\mathrm{Fe}^{2+}$ & 1 & 0,0 & 0,219 & 0,051 & 0,07 & 0,137 & 0,153 & 0,163 & 0,243 & i \\
\hline Al IV/Al & 1 & 7,771 & 3,816 & 13,258 & 1,309 & 3,637 & 2,081 & 1,48 & 12,963 & 1 \\
\hline $\mathrm{Al} / \mathrm{T} \mathrm{i}$ & 1 & 5,798 & 12,384 & 14,108 & 12,695 & 7,769 & 13,836 & 11,865 & 3,715 & 1 \\
\hline $\mathrm{Mg} / \mathrm{Mg}^{+} \mathrm{Fe}$ & 1 & 0,752 & 0,771 & 0,867 & 0,929 & 0,822 & 0,84 & 0,85 & 0.73 & \\
\hline $\mathrm{Fe} / \mathrm{Fe}^{+} \mathrm{Mg}$ & 1 & 0,248 & 0,229 & 0,133 & 0,071 & 0,178 & 0,16 & 0,15 & 0.27 & 1 \\
\hline
\end{tabular}

Tabel 111.6. Hasil analisis mikroprob piroksen dari basalt Karangsambung Utara. 


\begin{tabular}{|c|c|c|c|c|c|c|c|c|c|c|c|c|}
\hline 1 & & & & & & A & A & $\begin{array}{ll}\mathrm{L} & \mathrm{T}\end{array}$ & & & & \\
\hline 1 & $S P-1$ & SL-7 & LP-1 & SP-7 & $S L-8$ & SC-6 & SN-1 & SP-9 & PS- 12 & SP -6 & ST - 69 & SP-11 \\
\hline $\mathrm{SiO}_{2}(z) \mid$ & 43,32 & 43,45 & 45,01 & 45,04 & 46,36 & 46,43 & 47,1 & 47,54 & 48,37 & 49,48 & 49,48 & 51,66 \\
\hline $\mathrm{TiO}_{2} \quad 1$ & 0,15 & 0,9 & 1,08 & 0,91 & 1,0 & 0,99 & 0,96 & 1,01 & 1,07 & 1,06 & 0,92 & 1,11 \\
\hline $\mathrm{Al}_{2} \mathrm{O}_{3}$ & 13,51 & 14,54 & 15,98 & 16,65 & 15,58 & 15,29 & 18,21 & 16,42 & 15,41 & 17,2 & 16,5 & 16,68 \\
\hline $\mathrm{Fe}_{2} \mathrm{O}_{3}^{*}$ & 8,76 & 8,68 & 10,78 & 10,14 & 8,8 & 11,13 & 8,43 & 9,92 & 8,61 & 11,13 & 8,71 & 10,04 \\
\hline MnO & 0,11 & 0,17 & 0,2 & 0,21 & 0,19 & 0,16 & 0,11 & 0,15 & 0,15 & 0,15 & 0,14 & 0,22 \\
\hline Mgo & 4,38 & 9,02 & 7,62 & 5,54 & 9,12 & 5,77 & 8,05 & 5,81 & 9,62 & 4,87 & 8,6 & 2,03 \\
\hline $\mathrm{CaO}$ & 11,88 & 18,85 & 5,24 & 9,59 & 11,86 & 9,26 & 8,59 & 10,32 & 9,56 & 8,08 & 10,34 & 6,45 \\
\hline $\mathrm{Na}_{2} \mathrm{O}$ & 3,05 & 0,0 & 4,68 & 3,45 & 2,3 & 4,13 & 3,35 & 3,51 & 2,71 & 3,25 & 2,5 & 3,87 \\
\hline $\mathrm{K}_{2} \mathrm{O}$ & 1,58 & 0,02 & 0,11 & 0,8 & 0,15 & 0,95 & 0,22 & 0,2 & 0,1 & 1,48 & 0,24 & 1,06 \\
\hline $\mathrm{P}_{2} \mathrm{O}_{5}$ & 0,18 & 0,21 & 0,12 & 0,11 & 0,12 & 0,12 & 0,11 & 0,11 & 0,13 & 0,16 & 0,1 & 0,14 \\
\hline H.D & 12,48 & 4,02 & 7,53 & 6,66 & 4,37 & 5,56 & 4,11 & 4,49 & 3,35 & 3,41 & 2,23 & 5,71 \\
\hline Total & $.99,4$ & 99,86 & 98,35 & 99,1 & 99,85 & 99.79 & 99,24 & 99,48 & 99,26 & 100,27 & 99,46 & 98,97 \\
\hline$v(p p m)$ & 272,0 & 264,0 & 283,0 & 208,0 & 213,0 & 238,0 & 238,0 & 092,0 & 213,0 & 196,0 & 218,0 & 239,0 \\
\hline Cr $\quad$ I & 353,0 & 52,0 & 439,0 & 208,0 & 325,0 & 276,0 & 412,0 & 192,0 & 213,0 & 344,0 & 406,0 & 239,0 \\
\hline Co & 35,0 & 36,0 & 63,0 & 43,0 & 39,0 & 42,0 & 34,0 & 36,0 & 40,0 & 47,0 & 50,0 & 89,0 \\
\hline $\mathrm{Ni}$ & 76,0 & 102,0 & 82,0 & 66,0 & 158,0 & 57,0 & 87,0 & 41,0 & 164,0 & 77,0 & 111,0 & 65,0 \\
\hline $\mathrm{Zn}$ & 56,0 & 36,0 & 104,0 & $\pi, 0$ & 128,0 & 76,0 & 54,0 & 39,0 & 33,0 & 84,0 & 36,0 & 140,0 \\
\hline Rb & 19,0 & 0,5 & 3,0 & 13,0 & 2,0 & 19,0 & 3,0 & 3,0 & 2,0 & 27,0 & 4,0 & 22,0 \\
\hline Sr & 196,0 & 29,0 & 141,0 & 370,0 & 143,0 & 260,0 & 138,0 & 336,0 & 146,0 & 274,0 & 177,0 & 238,0 \\
\hline$Y$ & 26,0 & 26,0 & 15,0 & 30,0 & 24,0 & 22,0 & 21,0 & 19,0 & 24,0 & 24,0 & 22,0 & 19,0 \\
\hline $2 r$ & 92,0 & 72,0 & $\pi 5.0$ & 54,0 & 70,0 & 57,0 & 65,0 & 61,0 & 86,0 & 63,0 & 70,0 & 64,0 \\
\hline $\mathrm{Nb}$ & 6,7 & 2,0 & 4,9 & 4,5 & 1,7 & 4,8 & 1,2 & 4,6 & 2,7 & 5,1 & 2,7 & 5,7 \\
\hline \multicolumn{13}{|c|}{ NORM CIPW $\left(\mathrm{Fe}_{2} \mathrm{O}_{3}=0,15 \mathrm{Fe}_{2} \mathrm{O}_{3}^{\star}\right)$} \\
\hline $\begin{array}{ll}0 & 1\end{array}$ & & & & & & & . & & & & & 5,13 \\
\hline or & 10,83 & 0,12 & 0,72 & 5,16 & 0,94 & 6,02 & 1,38 & 1,25 & 0,62 & 9,11 & 1,46 & 6,78 \\
\hline$a b$ & 12,2 & & 39,87 & 24,51 & 20,53 & 25,04 & 30,0 & 31,52 & 24,12 & 28,65 & 21,84 & 35,41 \\
\hline an & 21,47 & 41,63 & 24.77 & 30,12 & 33,5 & 21,84 & 36,01 & 30,22 & 31,14 & 29,16 & 34,18 & 27,06 \\
\hline ne & 9,6 & & 2,25 & 3,98 & & 6,72 & & & & & & \\
\hline di & 37,81 & 44,64 & 2,74 & 17,37 & 22,46 & 21,95 & 6,81 & 19,24 & 14,45 & 9,64 & 14,68 & 5,66 \\
\hline hy & & 0,88 & & & 4,19 & & 5,3 & 0,1 & 17,34 & 10,68 & 20,08 & 94,96 \\
\hline ol & 5,07 & 8,41 & 24,46 & 14,28 & 14,07 & 13,52 & 16,36 & 13,05 & 7,9 & 7,74 & 3,73 & \\
\hline$m t$ & 2,21 & 1,98 & 2,61 & 2,41 & 2,02 & 2,59 & 1,94 & 2,29 & 1,97 & 2,52 & 1,96 & 2,36 \\
\hline il & 0,33 & 1,8 & 2,28 & 1,89 & 2,0 & 2,01 & 1,93 & 2,04 & 2,14 & 2,1 & 1,8 & 2,28 \\
\hline ap & 0,5 & 0,52 & 0,32 & 0,28 & 0,3 & 0,3 & 0,28 & 0,28 & 0,32 & 0,4 & 0,24 & 0,36 \\
\hline \multicolumn{13}{|l|}{0} \\
\hline or & 47,03 & 100,0 & 01,78 & 17,39 & 04,36 & 19,37 & 04,39 & 03,83 & 02,51 & 24,13 & 06,28 & 14,32 \\
\hline$a b \quad i$ & 52,97 & & 98,22 & 82,61 & 95,64 & 80,63 & 95,61 & 96,17 & 97,49 & $\pi, 87$ & 93,72 & 74,83 \\
\hline $\mathrm{Na}_{2} \mathrm{O}+\mathrm{K}_{2}$ 이 & 27,41 & 00,12 & 21,66 & 22,47 & 12,57 & 24,34 & 18,59 & 20,11 & 13,93 & 24,11 & 14,29 & 30,82 \\
\hline $\mathrm{FeO}^{c \star} \quad 1$ & 46,67 & 46,36 & 43,88 & 48,24 & 40,64 & 48,0 & 39,5 & 48,4 & 38,4 & 51,06 & 40,87 & 56,49 \\
\hline MgO & 25,93 & 53,52 & 34,46 & 29,29 & 46,79 & 27,65 & 41,91 & 31,49 & 47,67 & 24,83 & 44,84 & 12,69 \\
\hline DI & 32,63 & 0,12 & 42,84 & 33,65 & 21,46 & 37,77 & 31,38 & 32,78 & 24,74 & 37,76 & 23,31 & 47,32 \\
\hline SI & 25,76 & 52,99 & 34,15 & 28,97 & 46,34 & 27,44 & 41,67 & 31,24 & 47,32 & 24,64 & 44,52 & 12,52 \\
\hline
\end{tabular}




\begin{tabular}{|c|c|c|c|c|c|c|c|c|c|c|c|c|c|}
\hline & 1 & & $I A B A$ & & & 1 & & G A B R & & & S E R & & N I T \\
\hline & I PS-14A & $S L-6$ & $L K-36$ & $L-14 B$ & L-22 & SN-6 & $L-23$ & PS-16 & ST -7 & $C D-7$ & $C D-49$ & $S L-3 B$ & $C D-5 A$ \\
\hline $\mathrm{SiO}_{2}(x)$ & 146,69 & 47,47 & 47,89 & 47,95 & 50,23 & 47,3 & 47,71 & 48,52 & 50,6 & $51,63 \mid$ & 38,59 & 38,93 & 39,21 \\
\hline $\mathrm{TiO}_{2}$ & | 1,18 & 1,14 & 1,18 & 1,05 & 1,14 & 0,87 & 0,32 & 0,44 & 0,39 & 0,41 i & 0,15 & 0,02 & 0,02 \\
\hline $\mathrm{Al}_{2} \mathrm{O}_{3}$ & 15,21 & 16,03 & 16,08 & 16,42 & 15,16 & 15,38 & 19,09 & 18,3 & 16,48 & 17,44 I & 0,82 & 0,72 & 0,64 \\
\hline $\mathrm{Fe}_{2} \mathrm{O}_{3}^{\star}$ & | 10,31 & 9,34 & 9,22 & 8,71 & 8,75 & 0,91 & 5,56 & 6,19 & 4,35 & 6,131 & 8,64 & 8,0 & 8,37 \\
\hline Mno & I 0,18 & 0,15 & 0,15 & 0,16 & 0,12 & 0,15 & 0,09 & 0,12 & 0,9 & $0,11 \quad 1$ & 0,12 & 0,11 & 0,1 \\
\hline MgO & 10,9 & 8,58 & 8,73 & 8,4 & 8,7 & 8,76 & 8,58 & 8,67 & 9,91 & 6,531 & 38,16 & 38,27 & 36,38 \\
\hline $\mathrm{CaO}$ & 18,08 & 9,61 & 10,14 & 10,17 & 8,82 & 8,87 & 12,26 & 11,39 & 13,78 & 12,27 | & 0,02 & 0,04 & 1,22 \\
\hline $\mathrm{Na}_{2} \mathrm{O}$ & 12,3 & 3,1 & 2,57 & 2,62 & 3,32 & 3,81 & 2,22 & 2,57 & 2,17 & 3,011 & 0,0 & 0,03 & 0,0 \\
\hline $\mathrm{K}_{2} \mathrm{O}$ & 10,07 & 0,58 & 0,15 & 0,17 & 0,19 & 0,29 & 0,07 & 0,04 & 0,22 & 0,041 & 0,0 & 0,0 & 0,0 \\
\hline $\mathrm{P}_{2} \mathrm{O}_{5}$ & $1 \quad 0,12$ & 0,1 & 0,13 & 0,2 & 0,13 & 0,08 & 0,05 & 0,07 & 0,07 & 0,031 & 0,0 & 0,01 & 0,01 \\
\hline 0 & 13,88 & 3,28 & 2,8 & 3,03 & 2,89 & 4,97 & 3,34 & 2,93 & 1,98 & $1,46 \quad \mid$ & 13,21 & 12,8 & 13,87 \\
\hline Total & | 98,92 & 99,38 & 99,04 & 98,8 & 99,45 & 99,39 & 99,29 & 99,04 & 100,04 & 99,061 & 99,71 & 98,93 & 99,82 \\
\hline (ppm) & 1261,0 & 206,0 & 239,0 & 221,0 & 264,0 & 1210,0 & 117,0 & 133,0 & $1 \pi, 0$ & 179,0 & 43,0 & 31,0 & 31,0 \\
\hline $\mathrm{Cr}$ & 261,0 & 339,0 & 239,0 & 392,0 & 367,0 & 210,0 & 769,0 & 260,0 & 197,0 & 119,0 & 2117,0 & 2216,0 & 1737,0 \\
\hline Co & 150,0 & 45,0 & 39,0 & 38,0 & 38,0 & 140,0 & 29,0 & 31,0 & 22,0 & 28,0 & 1117,0 & 105,0 & 104,0 \\
\hline $\mathrm{Ni}$ & | 221,0 & 143,0 & 156,0 & 162,0 & 138,0 & $1.107,0$ & 176,0 & 112,0 & 180,0 & 59,0 & | 2282,0 & 2244,0 & 2102,0 \\
\hline $2 n$ & I 95,0 & 64,0 & 64,0 & 38,0 & 39,0 & I 57,0 & 26,0 & 34,0 & 10,0 & 33,0 & 150,0 & 48,0 & 42,0 \\
\hline Rb & $1 \quad 2,0$ & 8,0 & 2,0 & 4,0 & 3,0 & 18,0 & 3,0 & 2,0 & 6,0 & 1,0 & 2,0 & 2,0 & 1,0 \\
\hline $\mathrm{Sr}$ & | 140,0 & 187,0 & 42,0 & 177,0 & 195,0 & | 191,0 & 227,0 & 192,0 & 173,0 & 162,0 & 0,0 & 0,0 & 5,0 \\
\hline Y & I 27,0 & 29,0 & 26,0 & 24,0 & 25,0 & I 21,0 & 8,0 & 10,0 & 11,0 & 10,0 & 0,0 & 0,0 & 0,0 \\
\hline $2 r$ & 80,0 & 73,0 & 81,0 & $68 ; 0$ & 79,0 & 62,0 & 25,0 & 29,0 & 32,0 & 19,0 & 15,0 & 16,0 & 13,0 \\
\hline $\mathrm{Nb}$ & 3,3 & 1,0 & 1,2 & 1,7 & 2,6 & 2,2 & 0,6 & 1,1 & 1,0 & 0,0 & 0,0 & 0,0 & $1,86 \mid$ \\
\hline NORM CIPH & 1 & & & & & 1 & & & & & | & & \\
\hline & 1,71 & & 1,86 & 1,97 & 2,45 & 1 & & 0,14 & 0,25 & $3,91 \quad \mid$ & & & \\
\hline or & 0,44 & 3,57 & 0,92 & 1,5 & 1,16 & 1,81 & 0,43 & 0,25 & 1,31 & $0,24 i$ & & & \\
\hline$a b$ & 20,46 & 27,28 & 22,58 & 23,11 & 29,07 & 34,12 & 19,57 & 22,57 & 18,56 & $26,08 \mid$ & & 0,29 & \\
\hline an & 32,58 & 29,25 & 33,14 & 33,94 & 26,82 & 25,43 & 43,68 & 39.74 & 34.97 & 34.791 & 0,06 & 0,16 & 2,031 \\
\hline & 1 & & & & & 1 & & & & 1 & 0,93 & 0,72 & \\
\hline di & 4,09 & 12,62 & 11,41 & 11,11 & 10,94 & 14,07 & 14,47 & 13,59 & 26,25 & $20,51 \mid$ & & & 3,841 \\
\hline hy & 26,65 & 12,7 & 17,29 & 16,66 & 17,35 & 5,73 & 14,86 & 16,14 & 12,78 & $7,14 \mid$ & 39,22 & 39,55 & $38,83 \mid$ \\
\hline ol & 1 & 2,58 & & & & 7,6 & 0,48 & & & & 49,49 & 49,8 & $45,39 \mid$ \\
\hline $\mathrm{mt}$ & 1 & & & & & 1 & & & 1,83 & I & | & 0,35 & 0,311 \\
\hline$h m$ & 10,85 & 9,72 & 9,58 & 9,08 & 9,06 & 9,43 & 5,79 & 6,43 & 3,14 & 6,281 & 9,99 & 9,05 & 9,521 \\
\hline il & 0,41 & 0,33 & 0,33 & 0,36 & 0,27 & 0,34 & 0,2 & 0,27 & 0,75 & 0,241 & 0,3 & 0,04 & 0,041 \\
\hline sp & 2,52 & & 2,58 & 2,23 & 2,55 & 1 & & 0,78 & & $0,72 \quad$ & & & 1 \\
\hline pf & 1 & 1,72 & & & & 1,26 & 0,39 & & & 1 & 0,03 & & \\
\hline ap & 0,3 & 0,25 & 0,32 & 0,49 & 0,32 & 0,2 & 0,12 & 0,17 & 0,17 & 0,071 & & 0,03 & 0,031 \\
\hline & 7,57 & & 7,33 & 7,55 & 7,5 & 1 & & 0,62 & 1,24 & $12,93 \mid$ & & & \\
\hline or & $1 \quad 1,92$ & 11,56 & 3,63 & 4,01 & 3,56 & 5,05 & 2,16 & 1,07 & 6,53 & $0,8 \quad$ & & & \\
\hline$a b$ & 190,51 & 88,44 & 89,04 & 88,44 & 88,94 & 94,95 & 97,84 & 98,31 & 92,23 & $86,27 \mid$ & & 100,0 & \\
\hline $\mathrm{Na}_{2} \mathrm{O}+\mathrm{K}_{2} \mathrm{O}$ & I 10,51 & 17,81 & 13,77 & 14,66 & 17,48 & 19,64 & 14,43 & 15,49 & 14,74 & $20,2 \quad$ & & 0,07 & \\
\hline $\mathrm{FeO}$ & I 41,15 & 40,68 & 42,02 & 41,2 & 39,21 & 38,41 & 31,52 & 33,06 & 24,14 & 36,541 & 16,93 & 15,82 & 17,15 । \\
\hline MgO & 148,34 & 41,52 & 44,21 & 44,14 & 43,32 & 41,96 & 54.05 & 51,45 & 61,12 & 43,251 & 83,05 & 84.11 & 82,851 \\
\hline DI & I 22,61 & 30,84 & 25,36 & 26,13 & 32,69 & 35,94 & 20,0 & 22,95 & 20,12 & 30,231 & & 0,29 & \\
\hline I & 147,96 & 41,22 & 43,87 & 43,78 & 43,06 & 41,66 & 53.75 & 51,09 & 57,9 & $42,94 \quad \mid$ & 82,86 & 83,91 & 82,661 \\
\hline
\end{tabular}

Tabel IV.1b. Hasil analisis kimia batuan diabas, gabro, dan serpentinit daerah Karangsambung Utara. 


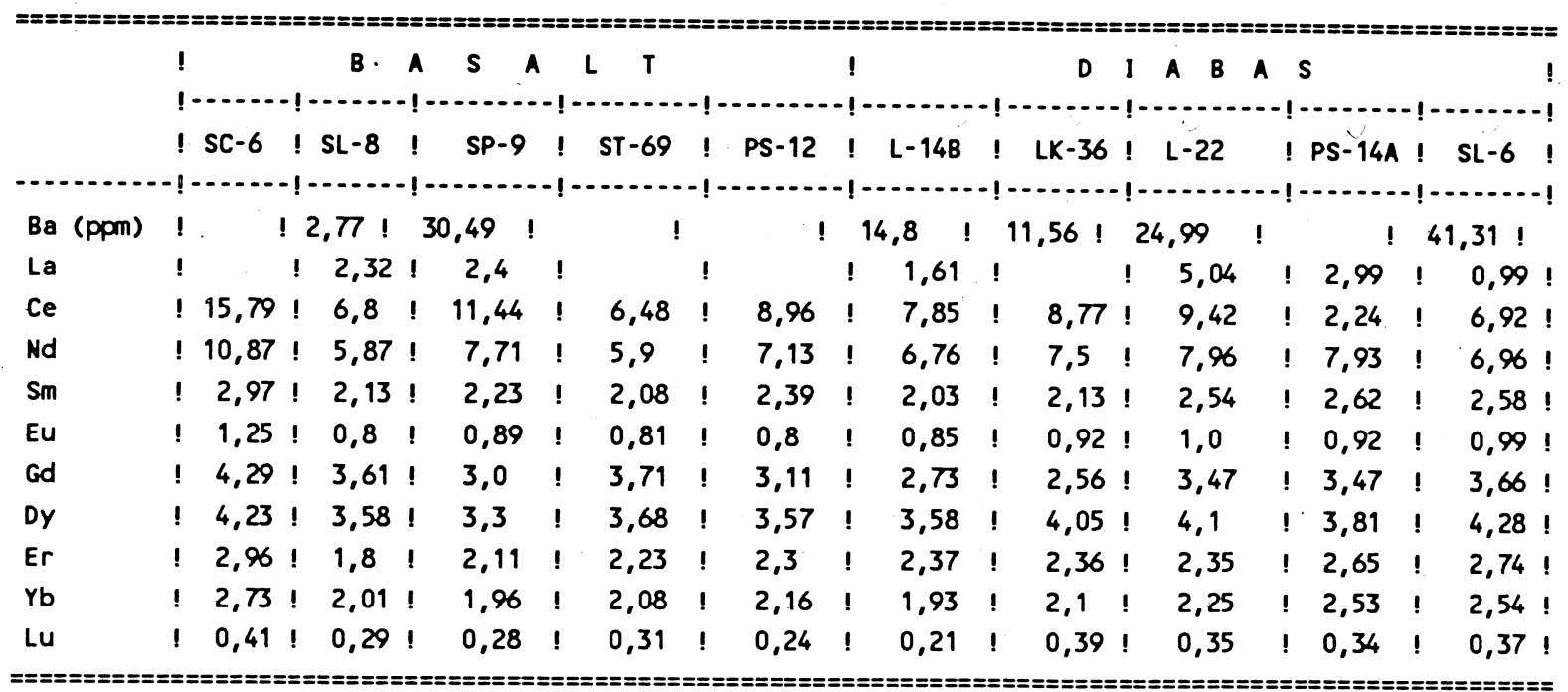

\begin{tabular}{|c|c|c|c|c|c|c|c|c|c|c|c|c|c|c|c|c|c|}
\hline & \multicolumn{3}{|l|}{$!$} & G A & \multirow[t]{2}{*}{ A $B$} & \multirow{2}{*}{\multicolumn{2}{|c|}{ R 0}} & \multirow{2}{*}{\multicolumn{2}{|c|}{......-1- }} & \multicolumn{2}{|r|}{$!$} & \multicolumn{3}{|c|}{$R \perp J A N G$} & \multirow[t]{2}{*}{$!$} & KONDRIT & \multirow{2}{*}{$\begin{array}{r}! \\
--!\end{array}$} \\
\hline & ! & & & & & & & & & $\cdots$ & $-!-$ & $\cdots \cdots$ & $-!-$ & & & . & \\
\hline & $!$ & $L-23$ & $!$ & PS- 16 & $!$ & $C D-7$ & $!$ & ST -7 & $!$ & SM- 6 & $!$ & $\mathrm{CH}-1$ & $!$ & $\mathrm{CH}-3$ & $!$ & C.I & $!$ \\
\hline & & & & & & & & & & & 4 & & & & & & ! \\
\hline Ba (ppm) & $!$ & 5,76 & $!$ & & $!$ & & $!$ & & $!$ & & $!$ & 10,02 & $!$ & 27,82 & $!$ & 2,2 & $!$ \\
\hline La & $!$ & & $!$ & & $!$ & & $!$ & & $!$ & & $!$ & & $!$ & & $!$ & 0,2446 & $!$ \\
\hline $\mathrm{Ce}$ & $!$ & 1,18 & 1 & 2,68 & $!$ & 1,41 & $!$ & 1,94 & $!$ & 5,77 & $!$ & 17,21 & $!$ & 9,12 & $!$ & 0,63379 & $!$ \\
\hline Nd & $!$ & 1,25 & $!$ & 2,64 & $!$ & 1,84 & $!$ & 1,78 & $!$ & 3,76 & $!$ & 10,26 & $!$ & 30,96 & $!$ & 0,4738 & 1 \\
\hline Sm & $!$ & 0,44 & $!$ & 1,03 & $!$ & 0,85 & $!$ & 0,97 & $!$ & 1,7 & $!$ & 2,11 & $!$ & 6,15 & $!$ & 0,154 & $!$ \\
\hline Eu & $!$ & 0,36 & $!$ & 0,53 & $!$ & 0,61 & $!$ & 0,43 & $!$ & 1,06 & $!$ & 0,47 & $!$ & 1,57 & $!$ & 0,058 & $!$ \\
\hline Gd & $!$ & 0,64 & $!$ & 1,42 & $!$ & 0,94 & $!$ & 0,92 & $!$ & & $!$ & 2,26 & $!$ & 7,06 & $!$ & 0,2043 & $!$ \\
\hline Dy & $!$ & 0,75 & $!$ & 1,68 & $!$ & 1,88 & $!$ & 1,04 & $!$ & 2,01 & $!$ & 2,13 & $!$ & 3,91 & $!$ & 0,2541 & $!$ \\
\hline Er & $!$ & $0,43$. & $!$ & 0,99 & $!$ & 1,05 & $!$ & 0,62 & $!$ & 1,2 & $!$ & 1,15 & $!$ & 3,54 & $!$ & 0,166 & $!$ \\
\hline$Y b$ & $!$ & 0,46 & $!$ & 0,97 & $!$ & 1,09 & $!$ & 0,55 & $!$ & 1,28 & $!$ & 1,06 & $!$ & 2,23 & $!$ & 0,1651 & $!$ \\
\hline Lu & $!$ & 0,1 & $!$ & 0,97 & $!$ & 0,16 & $!$ & 0,1 & $!$ & 0,17 & $!$ & 0,15 & $!$ & 0,29 & $!$ & 0,0254 & $!$ \\
\hline
\end{tabular}

Tabel IV.2. Hasil analisis UTL batuan basalt, diabas, gabro, rijang dan kondrit komplek ofiolit Karangsambung Utara 


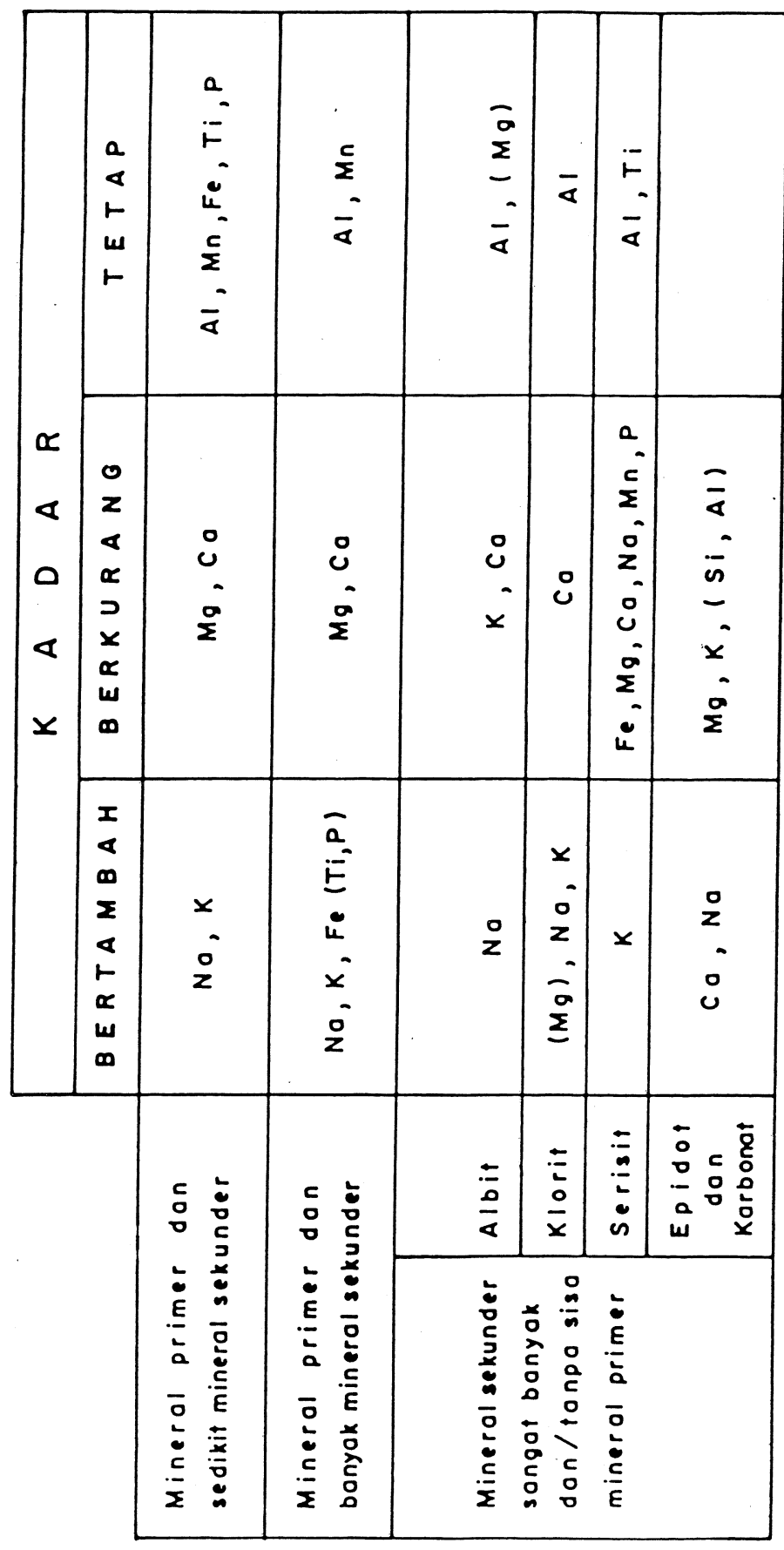

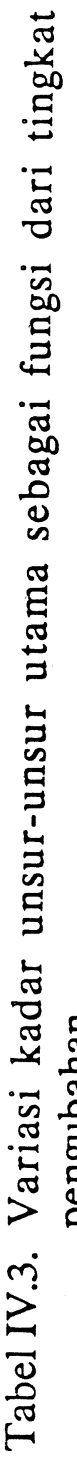




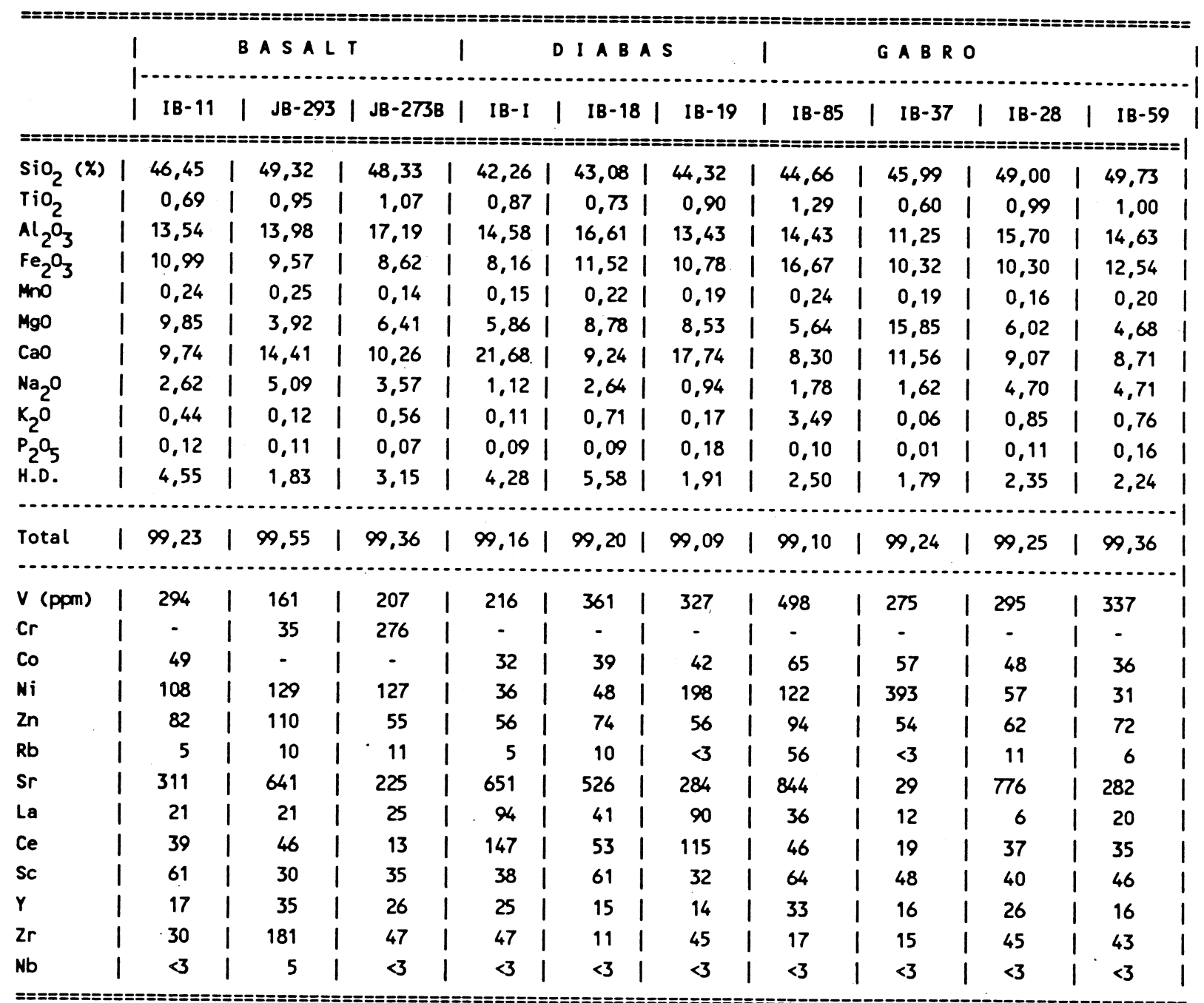

Tabel V.1a. Hasil anal is is batuan basalt, diabas dan gabro dari ofiolit Meratus - Bobaris (diperoleh dari Burgath, 1985). 


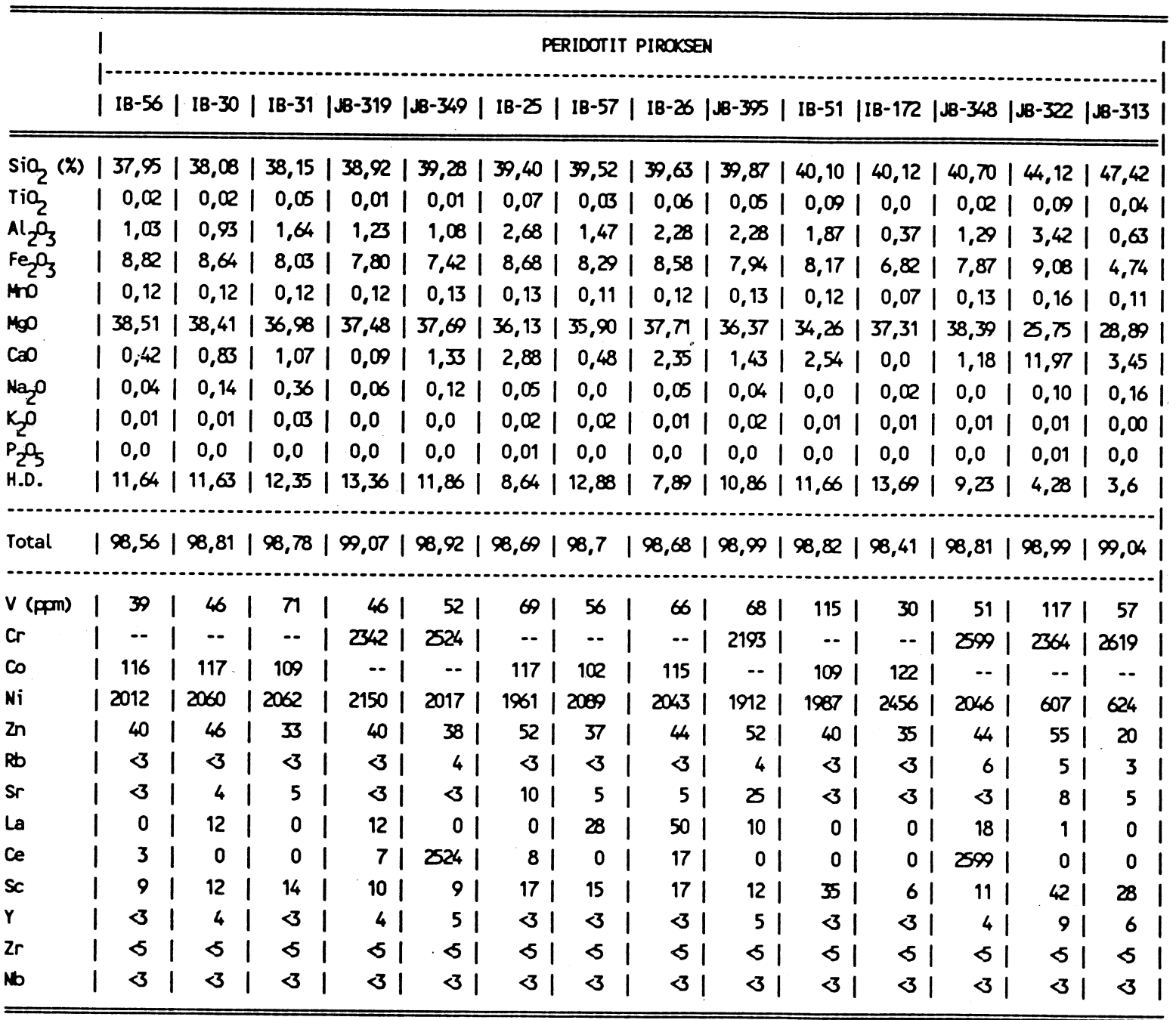

Tabel V.1b. Hasil analisis batum peridbtit piroksen dari of iol it Meratus - Babaris (diperoleh dari Burgath, 1985). 


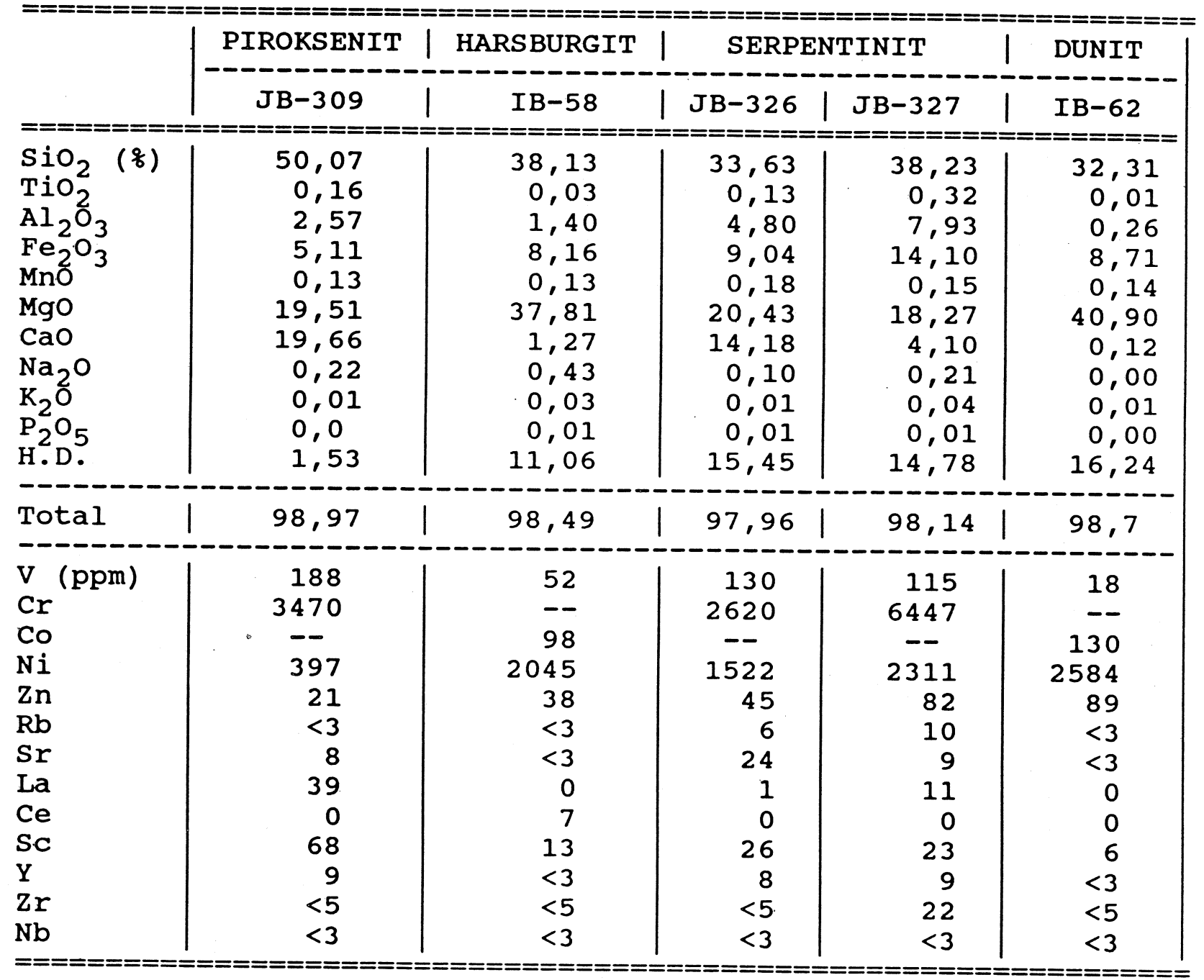

Tabel V.1C. Hasil analisis batuan piroksenit, harsburgit, serpentinit dan dunit dari ofiolit Meratus-Bobaris (diperoleh dari Burgath, 1985). 


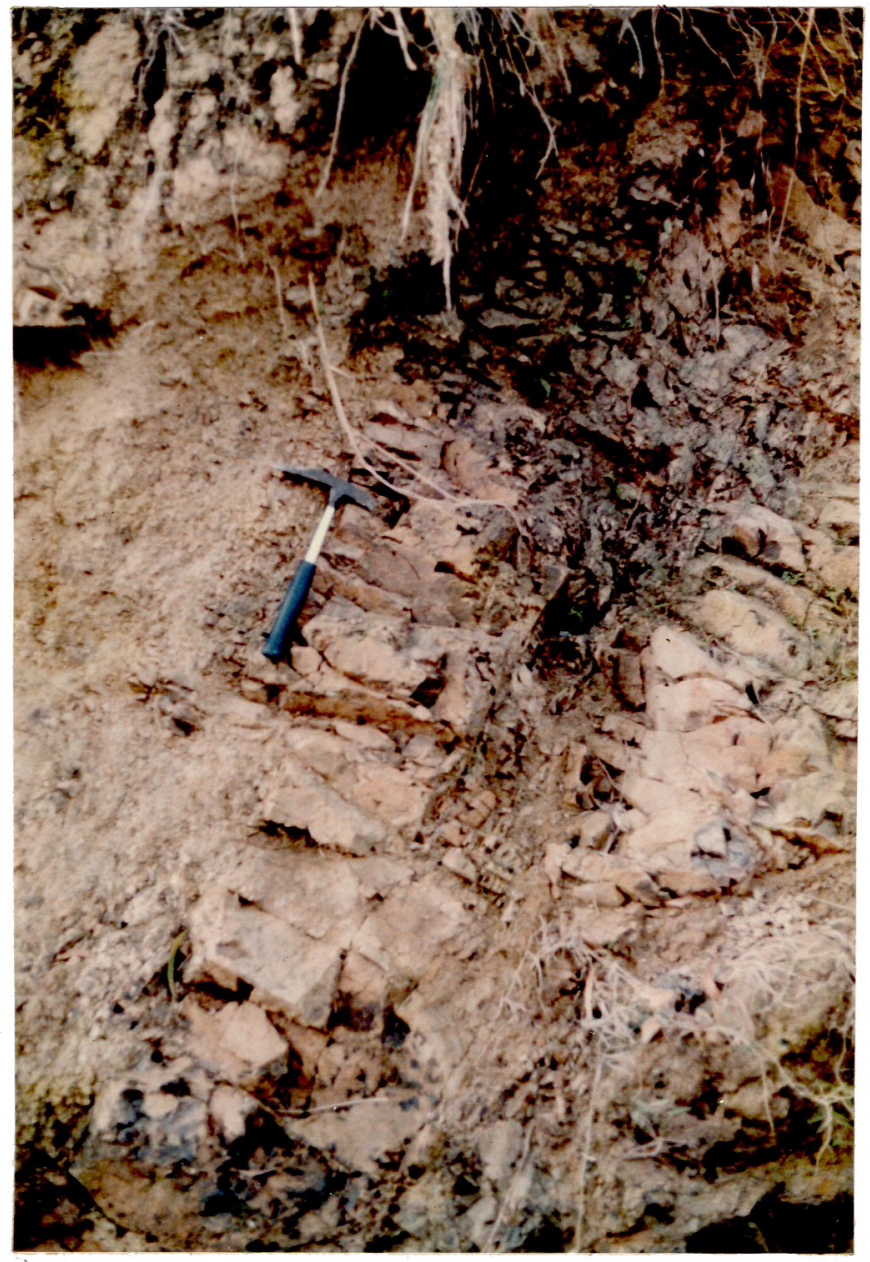

Foto 1. Bodin (boudin) batupasir yang terkepung di dalam batulempung tergerus kuat (pervasively sheared). Lokasi K. Cacaban. 
172

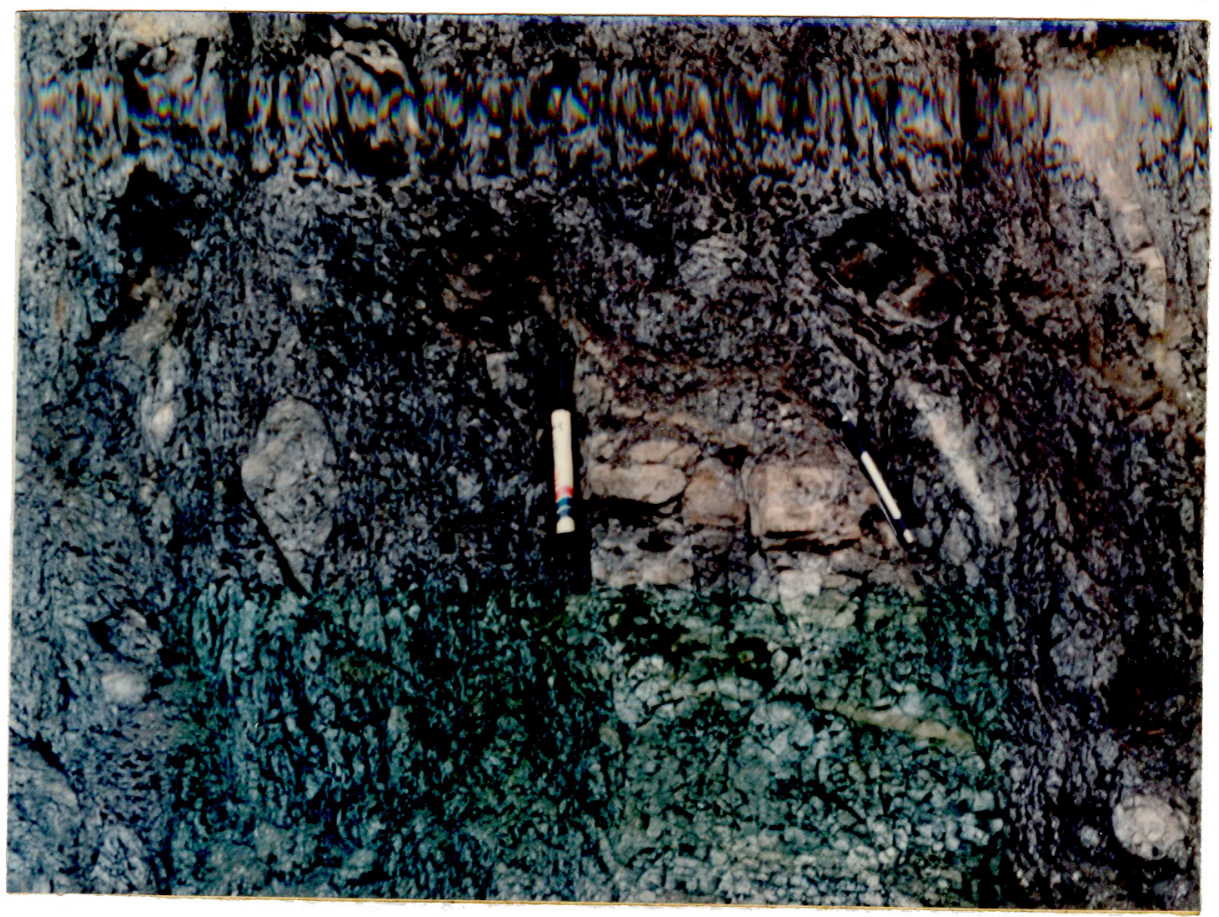

(a)

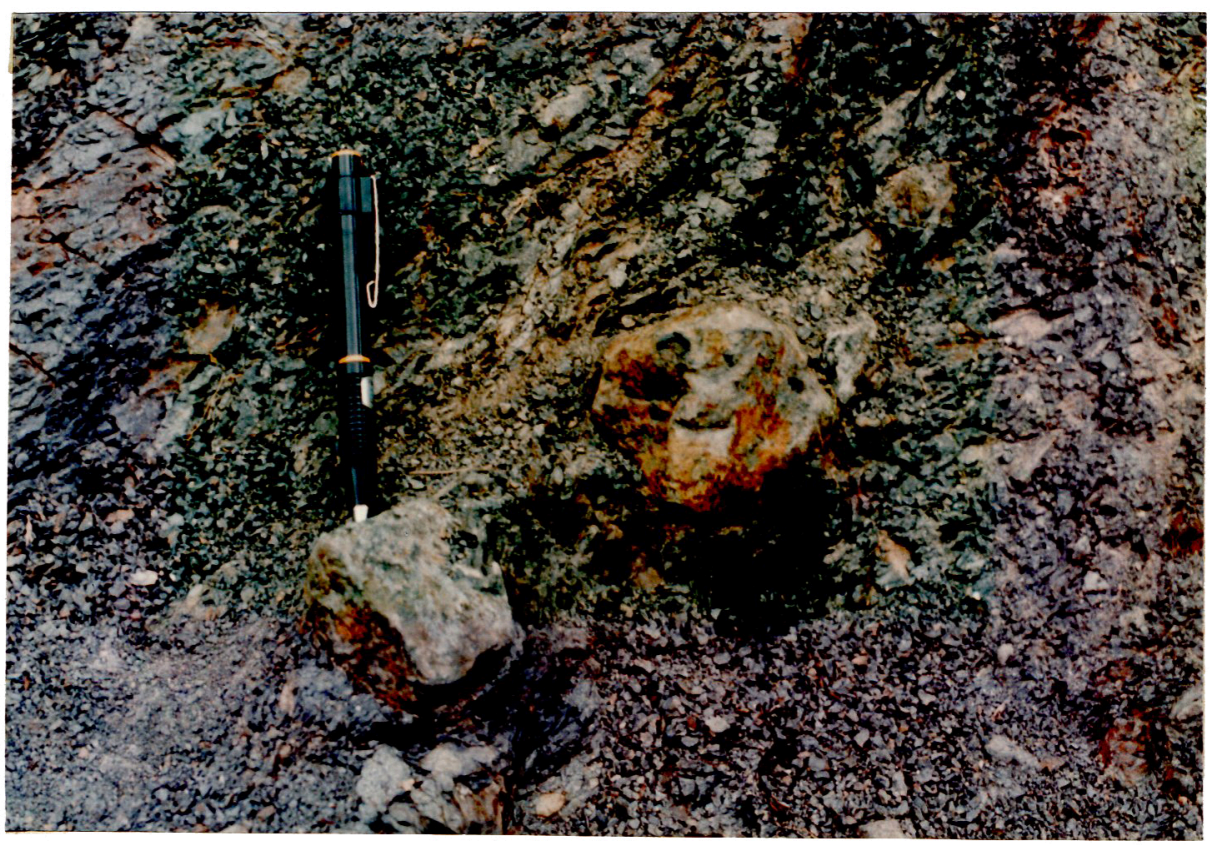

(b)

Foto 2. Keratan/bongkah batupasir di dalam lempung bersisik (scaly clay) dari Formasi Karangsambung (a) dan Formasi Totogan (b). Lokasi K. Salak-Banjarsari (a) dan K. Luh Ulo - Totogan (b). 


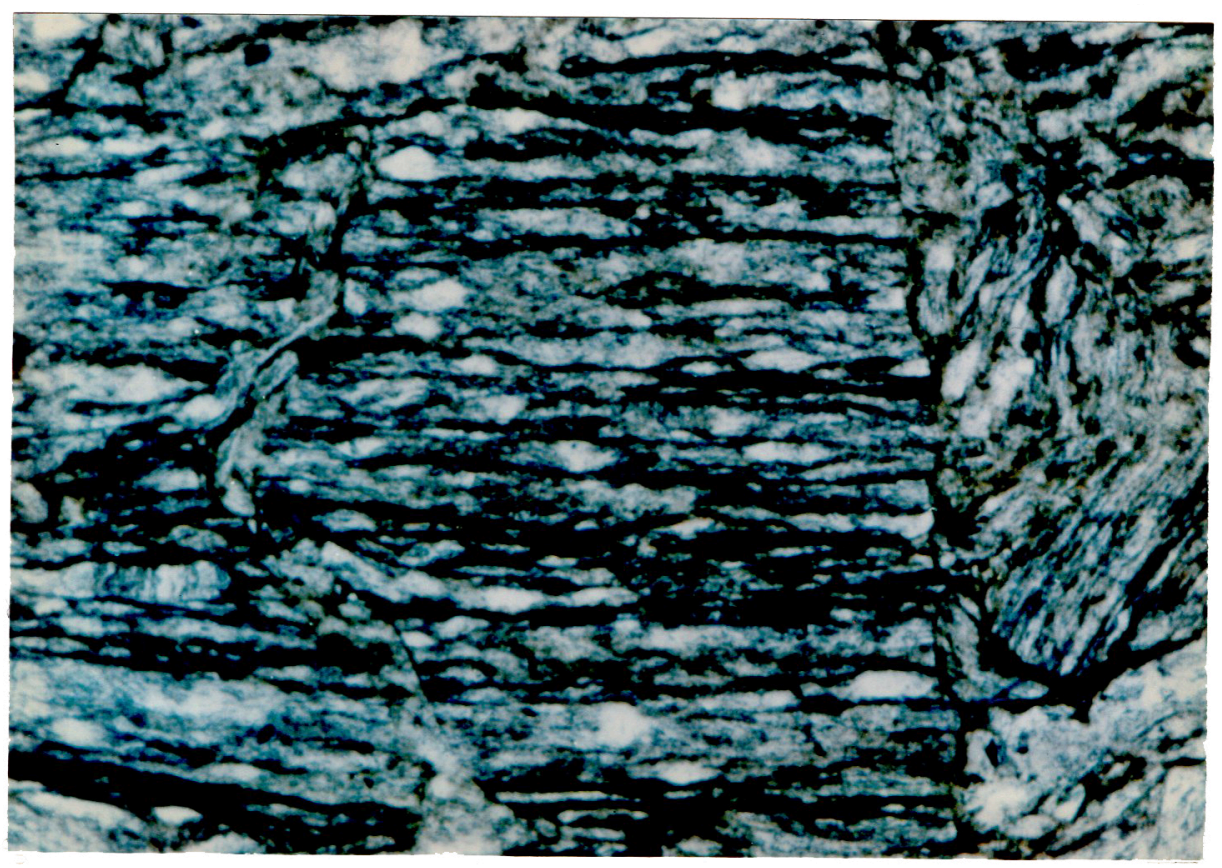

( a )
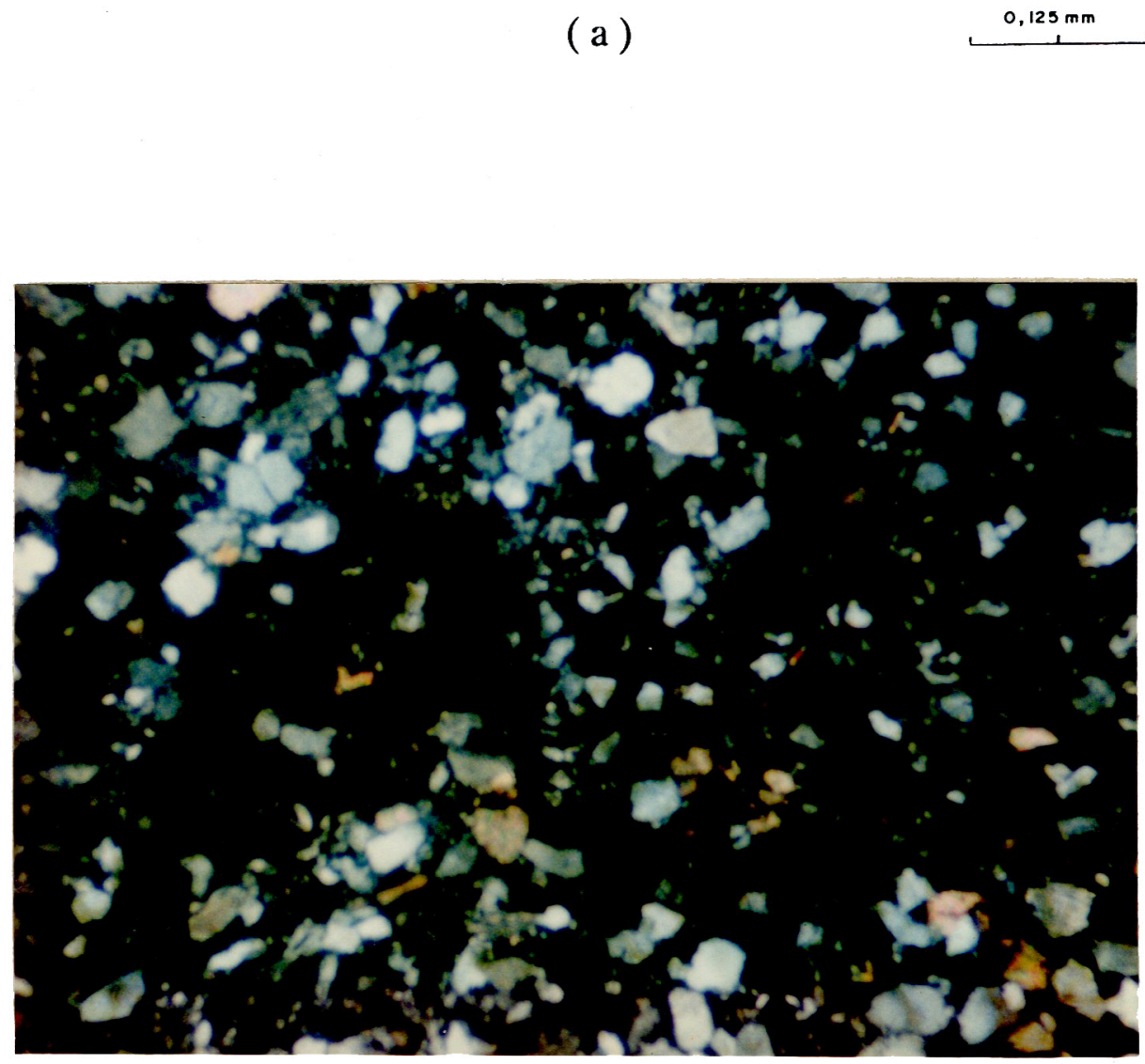

(b)

$0,5 \mathrm{~mm}$

Foto 3. Sayatan batusabak sebagai matriks (a) dan bodin batupasir terrekristalisasi (b) dari kompleks melange Luh Ulo. 


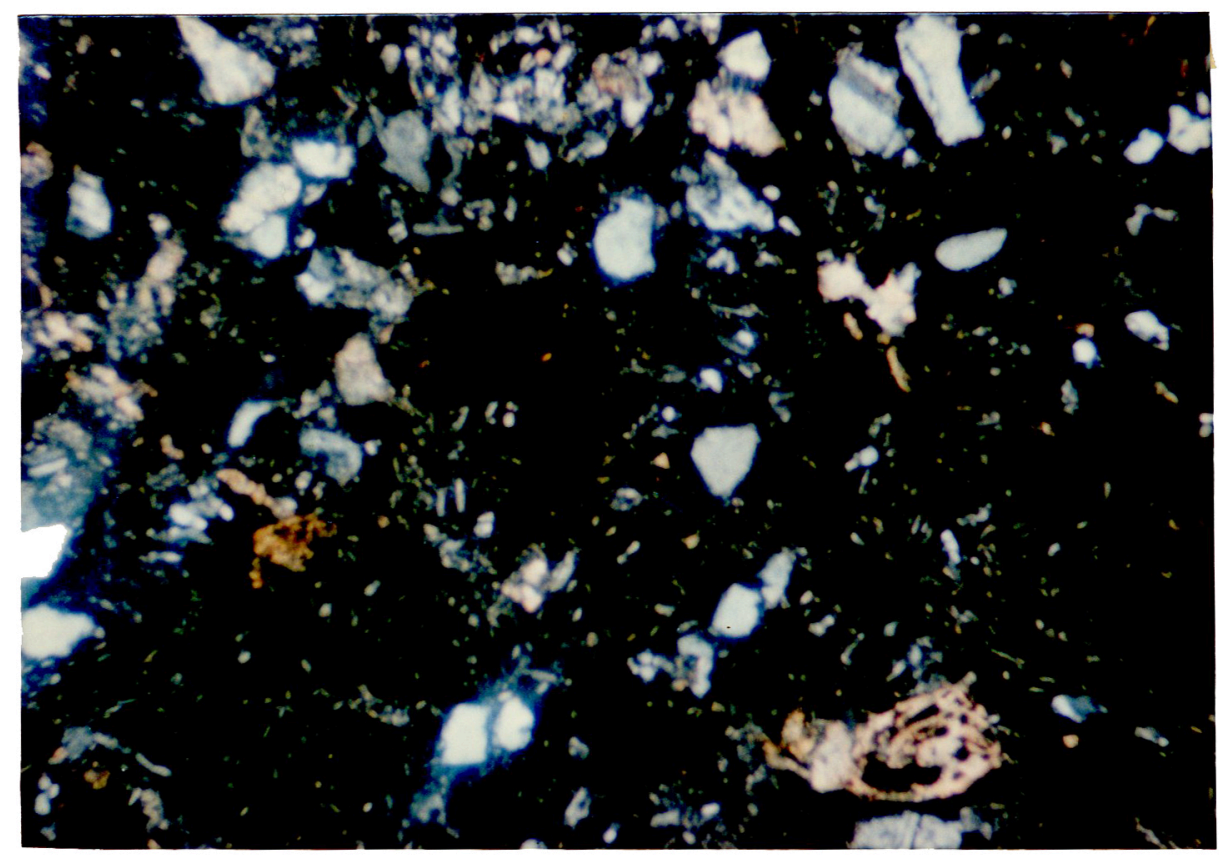

( a )
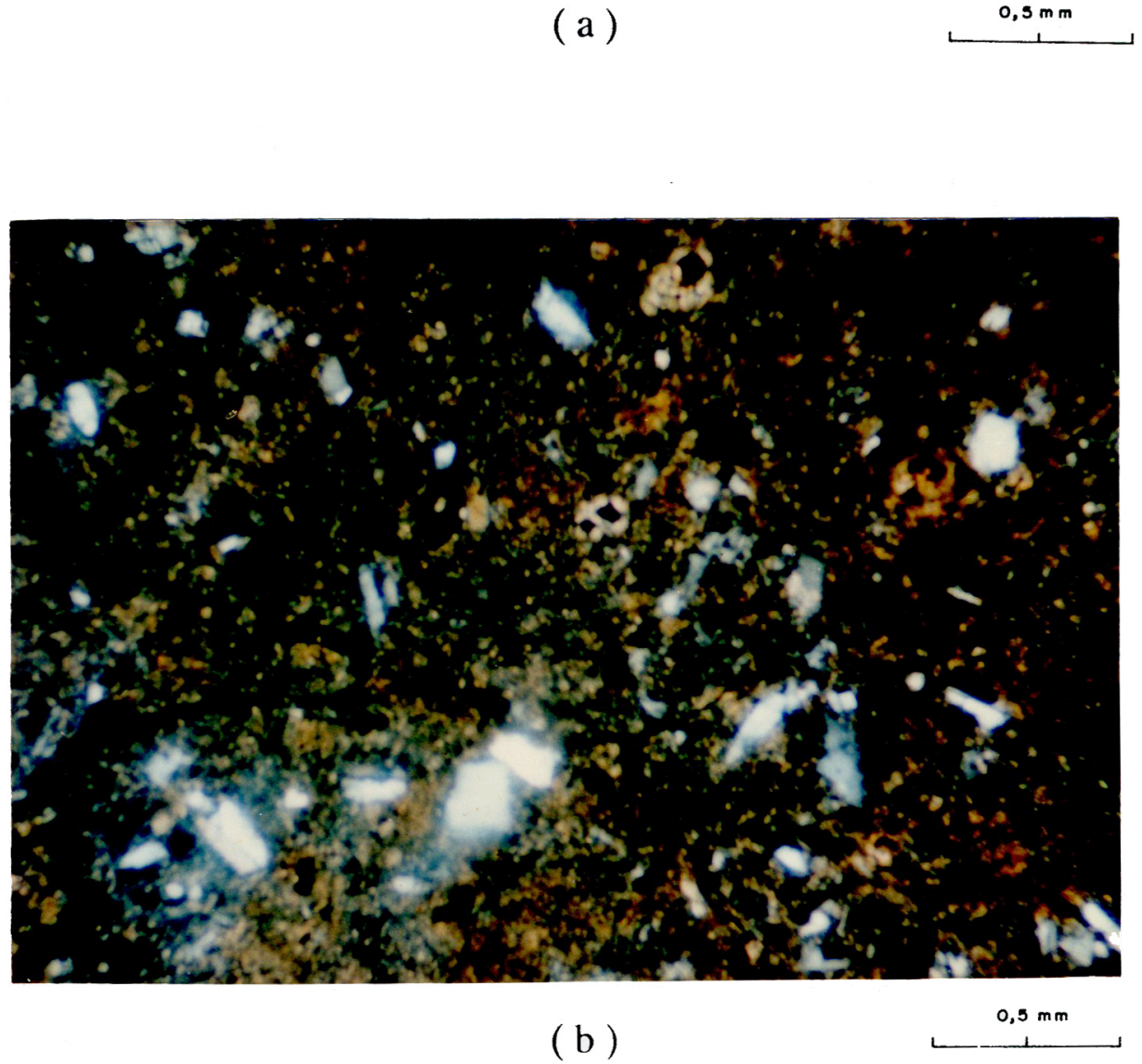

Foto 4. Sayatan batulempung sebagai matriks (b) dan keratan batupasir (a) Formasi Karangsambung. Perhatikan kehadiran cangkang fosil baik di dalam matriks maupun di dalam keratan batupasir. 


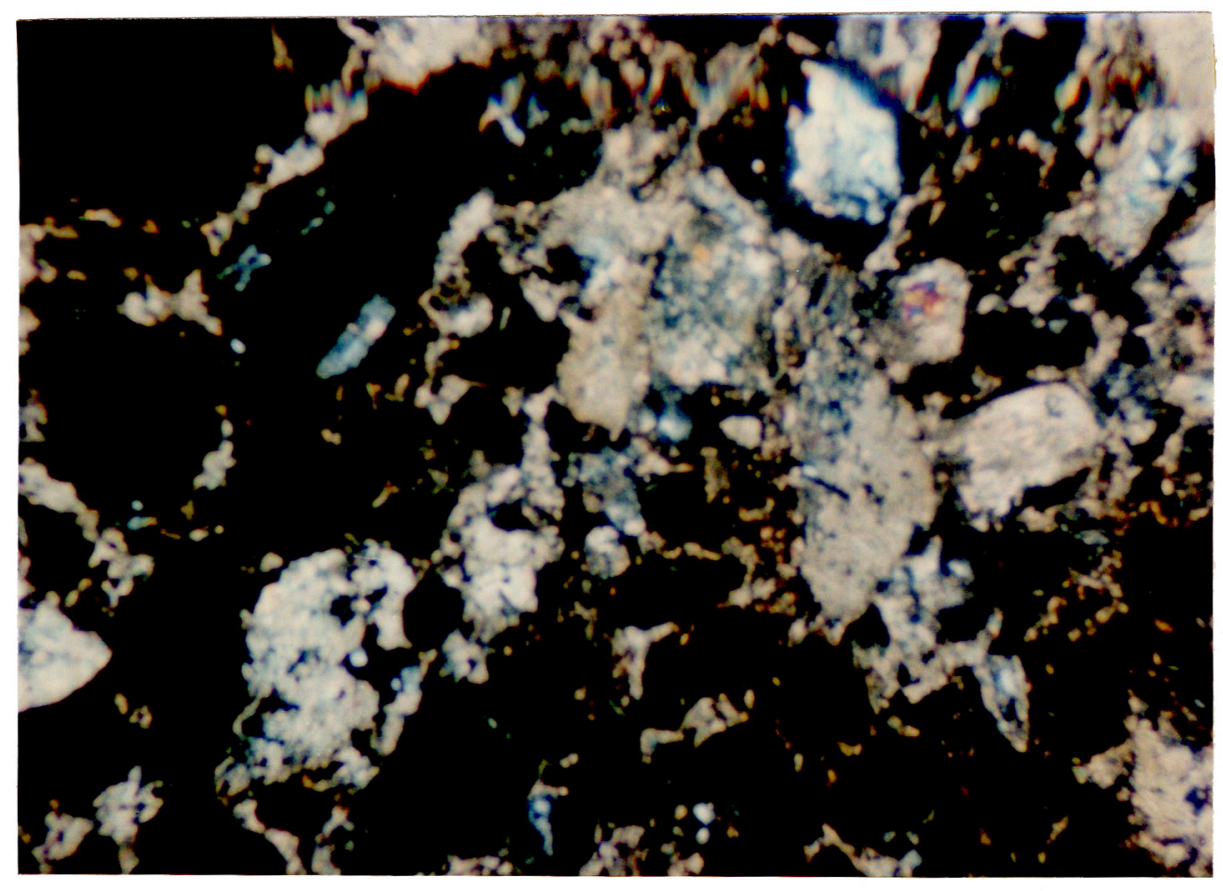

( a )

$0,5 \mathrm{~m} \mathrm{~m}$

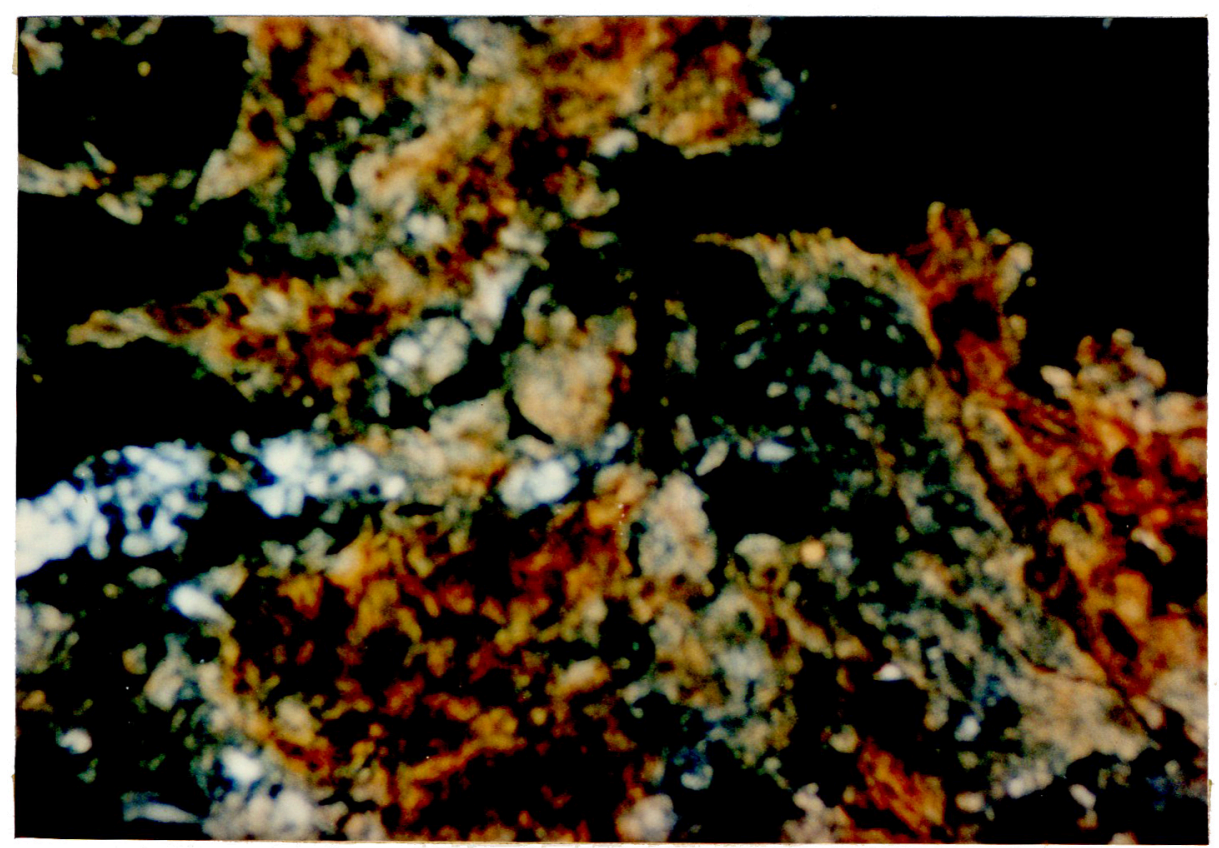

( b )

$0,5 \mathrm{~mm}$

Foto 5. Sayatan batulempung menyerpih sebagai matriks (b) dan bongkah batupasir (a) dari Formasi Totogan. 


\section{DAFTAR ISTILAH}

Acuan, referensi = reference; diacu $=$ referred

Aktivasi netron = neutron activation

Analisis pendar sinar $\mathrm{x}=x$-ray fluorescence

Apungan benua $=$ continental drift

Barik $=$ veinlet

Basalt bantal $=$ pillow basalt

Batuan asing = exotic rock; bongkah asing = exotic block -pribumi = native; -malihan, -metamorfosis = metamorphic rocks; -volkanik = volcanic-, -terobosan = intrusive-; -ultramafik = ultramafic-

Batu hias = ornamental stone

Busur = arc; sistem-palung $=$ arc-trench sistem; - belakang = back arc: -depan = fore arc; -kepulauan = island arc-kepulauan tak dewasa = immature island $\operatorname{arc}$

Bodin $=$ boudin

Cekungan = basin $;$-akresi, -kukupan = accreationary-; -antar busur = inter arc-; -depan busur = fore arc-; -luar busur = outer arc-; -depan daratan = foreland-; -sedimentasi $=$ sedimentary $;$-tepi $=$ marginal basin $;-$ kolam $=$ pond

Cuatan, lentikan = obduction; tercuatkan, terlentikan = obducted

Celah $=$ split

Dinormalisasi $=$ normalized to

Gunungapi bawah laut $=$ seamount

Jalur = belt; -orogen = orogenic-; -berpasangan = paired belt

Jejak belah $=$ fission track

Kala $=$ period

Kalk alkali $=$ calc alkali

Kelimpahan $=$ abundance 


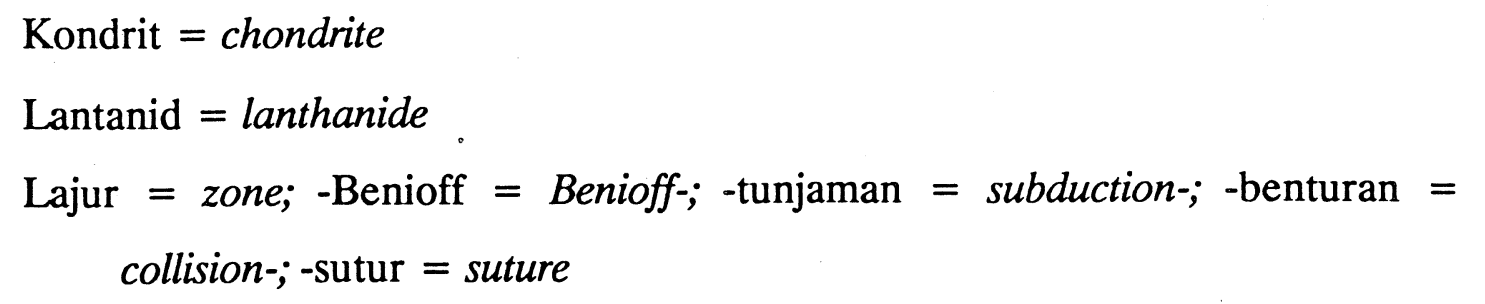

Laut tepi $=$ marginal sea

Lemping $=$ slab

Lempung bersisik $=$ scaly clay

Mantel atas = upper mantle; - utuh = undepleted-

Melange tektonik = tectonic melange; - sedimen (olistostrom) $=$ olisthostrome

Menyusup = underthrust

Naikan $=$ rise

Ofiolit = ophiolite

Orogenik $=$ orogenic

Palung, parit $=$ trench

Paparan $=$ shelf $;$-benua $=$ continental-; -endapan $=$ deposits

Pelelehan = melting; -sebagian = partial melting

Peluruhan $=$ decay

Pemalihan, metamorfisme $=$ metamorphism $;$ termalihkan $=$ metamorphosed

Pemekaran = spreading; -lantai samudera = ocean floor-; -belakang busur = back arc-; -pusat $=$ spreading centre

Penanggalan, pentarikhan $=$ dating

Penunjaman; tunjaman = subduction;

Pengubah = transformer $;$-an, ubahan = transformation, alteration

Pengurangan $=$ depletion

Penggantian $=$ replacement $;$-sebagian $=$ partial -

Plangton $=$ plankton

Punggung samudera $=$ oceanic ridge $;$-tengah samudera $=$ mid oceanic-

Prisma akresi = accretionary prism

Rajah $=$ plot 
Rangkaian = suite; -toleit $=$ tholeiite-; -alkali kalsium = calc alkalic-;

Retas, korok $=$ dyke

Rekahan = rift; perekahan $=$ rifting

Retakan $=$ fracture; -peretakan = fracturing

Sedimen pelagos (pelagik) = pelagic sediments; -terestrial, -asal darat = terrestrial-;

Sentuhan $=$ contact

Senolit $=$ xenolith

Serpentinisasi $=$ serpentinisation; terserpentinkan $=$ serpentinized

Sesar = fault; - bongkah = block-; - geser/jurus = strike slip-; -pengubah = transformed-; -sungkup = thrust-;

Sistem busur-palung $=$ arc-trench system

Spektrometri massa $=$ mass spectrometry; Pengenceran isotop $=$ dilution isotopic

Taji $=$ wedge $;$-melange $=$ melange wedge

Tatanan tektonik regional $=$ regional tectonic setting

Tektonostratigrafi = tectonostratigraphy

Tepian pasif = passive margin

Tergerus, terabak $=$ sheared

Lemping $=$ slab; -sesar sungkup $=$ thrust -

Toleit = tholeiite; -samudera = oceanic tholeiite

Ubahan; pengubahan = alteration; mineral ubahan = alteration mineral

Unsur = element $;$-utama = major $-;$-jejak = trace-; -tanah langka $=$ rare earth -

Urutan $=$ order

Waktu paruh $=$ half time

Wilayah $=$ region

\section{DAFTAR SINGKATAN}

A = Alkali

$\mathrm{Ab}=$ Albite $=$ albit 


$$
\begin{aligned}
& \mathrm{Ar}=\text { Argon } \\
& \mathrm{An}=\text { Anorthite }=\text { anortit } \\
& \mathrm{Ba}=\text { Barium } \\
& \mathrm{Ce}=\text { Cerium } \\
& \mathrm{Cr}=\text { Chromium }=\text { krom } \\
& \mathrm{D}=\text { Non orogenik } \\
& \mathrm{Dy}=\text { Dysprosium }=\text { disprosium } \\
& \mathrm{En}=\text { Enstatite }=\text { enstatit } \\
& \mathrm{Fs}=\text { Ferrosillite } \\
& \text { Gd }=\text { Gadolinium } \\
& \text { H.D. }=\text { Hilang dibakar }
\end{aligned}
$$

HREE = Heavy rare earth element

ID $=$ Indeks diferensiasi

$\mathrm{K}=$ Kalium

$\mathrm{KA}=$ Kalk alkali

$\mathrm{La}=$ Lanthanum $=$ lantanum

LREE = Light rare earth element

$\mathrm{Lu}=$ Lutetium $=$ lutesium

$\mathrm{Nb}=$ Neobium

$\mathrm{Nd}=$ Neodymium $=$ neodimium

$\mathrm{Ni}=$ Nickel $=$ nikel

$\mathrm{O}=$ Orogenik

$\mathrm{Rb}=$ Rubidium

$\mathrm{Sr}=$ Strontium $=$ stronsium

REE $=$ Rare earth element

$\mathrm{T}=$ Toleit

$\mathrm{TS}=$ Toleit Samudera

$\mathrm{UTL}=$ Unsur Tanah Langka

$\mathrm{V}=$ Vanadium 
Wo $=$ Wollastonite $=$ wolastonit

$\mathrm{Y}=$ Yttrium $=$ itrium

$\mathrm{Zr}=$ Zirconium $=$ zirkonium

MORB $=$ Mid-oceanic ridge basalt

PTS = Punggung Tengah Samudera

DSDP $=$ Deep sea drilling program

U.S. = United States

$\mathrm{Jt}=\mathrm{Juta}$ 


\section{RIWAYAT HIDUP}

Penulis dilahirkan pada tanggal 17 April 1948 di Denpasar, Bali. Ia lulus dari SMA di Jogjakarta pada tahun 1965 dan memasuki Perguruan Tinggi.

Ia memperoleh gelar Sarjana Strata-1 pada tahun 1973 dalam bidang geologi dari Jurusan Teknik Geologi Institut Teknologi Bandung dan sejak tahun 1973 ia menjadi anggota staf pengajar di Jurusan Teknik Geologi Institut Teknologi Bandung.

Dari bulan Mei 1981 hingga bulan Juli 1983 ia berada di Perancis dalam rangka program sandwich untuk memperdalam bidang petrologi dan geokimia (unsur-unsur jejak dan tanah langka) khususnya tentang batuan mafis - ultramafis di Universite de Paris VI.

Penulis menikah dengan Suparka pada tahun 1975 dan mempunyai satu orang anak laki-laki yaitu Krishnamurti berusia 13 tahun. 